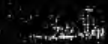


$-$ 
Ge 977.2 5w96c

Sweet, Willi im Warmen, 18811959.

Circuit-rider days in

Indiana 



\title{
CIRCUIT-RIDER DAYS IN INDIANA
}

\author{
BY \\ WILIIAM WARREN SWEET \\ Professor of History in DePaum University.
}

W. K. STEWART CO., Indianapolis, 1916. 
Allen County Public Librany

900 Websar Street

PO Box 2:70

Fort Wayne, IN 46801-2270

Copyright, 1916

BI WILLIAM W. SIVEET 


\section{1}

TO THE CIRCEIT RIDERS OF OLD

Who contributed so largely to Indiana's Life;

And to those who have entered into their labors. 



\section{INTRODUCTION.}

If there ever is an appropriate time for the publication of such a volume as this, it is the year 1916, which marks the 100th anniversary of Indiana's admission to the Union and it is hoped that this volume will, in a sense, be recognized as Indiana Methodism's contribution to the historical literature of the centennial year. This book has been endorsed by the Indiana Conferences of the Methodist Episcopal Church, and to a certain degree they have made its publication possible, and for this reason I wish to express my gratitude to them, and especially to their Centennial Committees, for their encouragement, in its preparation.

The Minutes of the old Indiana Conference, have never been published, and since they cover the important years, from 1832 to 1844 , the years in which Indiana Asbury University was founded, and also the years in which Matthew Simpson and Edward R. Ames were active in its councils, it was thought that the centennial year was an appropriate time to give these Minutes to the Methodists of Indiana. Accordingly the second, and largest part of this volume is devoted to these Minutes. They have been edited with notes, which it is hoped will explain all things necessary for their intelligent reading by an Indiana Methodist.

In editing the Minutes, I have been assisted by six of my students, at DePauw University, who constituted a Seminar in Early Indiana Methodist History, during the winter of 1915-1916. These students are E. J. Wickersham, Charles A. Kuttler, Fred D. Bacon, Miss Gladys Light, Roy C. Lockwood, and J. N. Simmons. Miss Ruth Price, a graduate student in the Depart- 


\section{INTRODUCTION.}

ment of History, in 1914-1915, is largely responsible for the material used in Chapter II, Part 1, on "Indiana Methodism, 1816-1832." The maps have been drawn by Mr. H. G. Bailey and Mr. E. E. Aldrich. I gratefully acknowledge their assistance, and take this opportunity of commending their work. W. W. S.

Greencastle, Indiana, December 15, 1915. 


\title{
CONTENTS.
}

Introduction.

\author{
PART I.
}

Chapter I. The Planting of Methodism in Indiana -.........-.

Chapter II. Indiana Methodism, 1816-1832 $1-29$ Chapter III. The Old Indiana Conference,

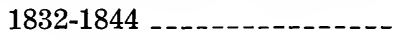
$30-51$

PART II.

I. Journal of the First Annual Session of the Indiana Conference, New Albany, Indiana, October, 1832.

$52-89$ 90-110

II. Journal of the Second Annual Session of the Indiana Conference, Madison, Indiana, October, 1833

III. Journal of the Third Annual Session of the Indiana Conference, Centerville, Indiana, October, 1834

IV. Journal of the Fourth Annual Session of the Indiana Conference, Lafayette, Indiana, October, 1835

V. Journal of the Fifth Annual Session of the Indiana Conference, Indianapolis, Indiana, October, 1836

VI. Journal of the Sixth Annual Session of the Indiana Conference, New Albany, Indiana, October, 1837 169-184

VII. Journal of the Seventh Annual Session of the Indiana Conference, Rockville, Indiana, October, 1838

VIII. Journal of the Eighth Annual Session of the Indiana Conference, Lawrenceburg, Indiana, October, 1839_- 203-222 


\section{CONTENTS}

IX. Journal of the Ninth Annual Session of the Indiana Conference, Indianapolis, Indiana, October, 1840_-_-_- 222-243

X. Journal of the Tenth Annual Session of the Indiana Conference, Terre Haute, Indiana, October, 1841_._._- 243-273

XI. Journal of the Eleventh Annual Session of the Indiana Conference, Centerville, Indiana, October, 1842_.__ 273-303

XII. Journal of the Twelfth Annual Session of the Indiana Conference, Crawfordsville, Indiana, October, 1843_-- 303-333 Bibliography _....... 334-339 Index. 


\section{CIRCUIT RIDER DAYS IN INDIANA}

\section{CHAPTER I.}

THE PLANTING OF METHODISM IN INDIANA.

A STUDY of the genesis of Methodism in Indiana must begin with the coming of the first settlers, and the settlement of Indiana did not in any real sense begin until after the close of the Indian wars, which were terminated by General Anthony Wayne in his successful campaign of 1794 . At the battle of Fallen Timbers, fought August 20, 1794, the Miami Indian Confederacy received its death blow, and the treaty of Greenville, signed the next year, opened up half of Ohio and a narrow strip of triangular shape in the southeast corner of what is now Indiana, to settlement. ${ }^{1}$ This territory however was not the first to be settled in Indiana, for the old French town of Vincennes had been in existence since the early years of the eighteenth century, and besides that Virginia had granted George Rogers Clark and his men, who had taken part in his campaign against Vincennes during the Revolution, 150,000 acres of land on the Ohio River, and this grant had been confirmed by the United States in 1784 after the territory north of the Ohio had been ceded by Virginia. With the close of the Indian wars settlers began to move into these grants, and the census of 1800 shows that there was a population in what is now Indiana of nearly three thousand. Vincennes and vicinity had 1,538, while Clark's grant

1 Esilrey. History of Indiana. 123. 124. 127. 


\section{CONTENTS}

IX. Journal of the Ninth Annual Session of the Indiana Conference, Indianapolis, Indiana, October, 1840_-_--- 222-243

X. Journal of the Tenth Annual Session of the Indiana Conference, Terre Haute, Indiana, October, 1841_._._- 243-273

XI. Journal of the Eleventh Annual Session of the Indiana Conference, Centerville, Indiana, October, 1842___- 273-303

XII. Journal of the Twelfth Annual Session of the Indiana Conference, Crawfordsville, Indiana, October, 1843__- 303-333

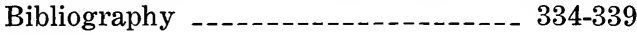
Index. 


\section{CIRCUIT RIDER DAYS IN INDIANA}

\section{CHAPTER I.}

THE PLANTING OF METHODISM IN INDIANA.

A STUDY of the genesis of Methodism in Indiana must begin with the coming of the first settlers, and the settlement of Indiana did not in any real sense begin until after the close of the Indian wars, which were terminated by General Anthony Wayne in his successful campaign of 1794. At the battle of Fallen Timbers, fought August 20, 1794, the Miami Indian Confederacy received its death blow, and the treaty of Greenville, signed the next year, opened up half of Ohio and a narrow strip of triangular shape in the southeast corner of what is now Indiana, to settlement. ${ }^{1}$ This territory however was not the first to be settled in Indiana, for the old French town of Vincennes had been in existence since the early years of the eighteenth century, and besides that Virginia had granted George Rogers Clark and his men, who had taken part in his campaign against Vincennes during the Revolution, 150,000 acres of land on the Ohio River, and this grant had been confirmed by the United States in 1784 after the territory north of the Ohio had been ceded by Virginia. With the close of the Indian wars settlers began to move into these grants, and the census of 1800 shows that there was a population in what is now Indiana of nearly three thousand. Vincennes and vicinity had 1,538, while Clark's grant

1 Esarey. History of Indiana. 123, 124, 127. 
had 919.2 Most of these first settlers came from across the Ohio river, from Kentucky, Tennessee, Virginia and North Carolina, and a considerable number of them had been members of Methodist classes in the older states, though the Methodist was not the only denomination ${ }^{3}$ represented among these first settlers, but Baptists, Presbyterians and Quakers were also numerous. Speaking of the migration of settlers after the Wayne campaign, into Ohio and Indiana, and its effect upon Methodist societies in Kentucky and other places within the western country, one of the pioneer preachers writes: "The Indian wars having terminated, the people began to scatter in every direction. New settlements were formed, and Ohio and Indiana began to settle rapidly, and the societies, many of them were broken up, and we had not preachers sufficient to follow the tide of emigration to their new settlements"; and as a result of this situation there was a decrease of members in the Western conference from 1795 to 1801.5

Previous to 1800 the Methodist conference in the western country was called the Kentucky conference, but in this year the name was changed to the Western conference and it so remained until 1812 when it was divided into the Ohio and the Tennessee conferences."

2 Ibid, 179.

3 W. C. Smith, "Indiana Miscellany," 43.

The Methodists were not the most numerous religious body among the early settlers in Indiana. It is probable that they were less numerous than either the Baptist or the New Lights.

4 Antobiography of Rev. William Burke contained in Finley's "Sketches of Western Methodism." 22-92.

5 In 1797 there were 1,170 white members and 57 colored reported for the Kentucky District. In 1799 the membership had decreased to 1,672 white, though there was a gain of eight colored. General Minutes, Vol. I, 74, 86 .

6 The General Conference of 1796, divikled the Methodist Episcopal church into six conferences, among them being the "Western Conference" [Sherman, "History of the Discipline," 319]. The 
In 1800 the Kentucky district contained nine circuits embracing Kentucky, and the settled parts of what is now Ohio and a part of Tennessee. These circuits were manned by fourteen preachers and one Presiding Elder, the redoubtable William McKendree. The names of the circuits in this district were, the Scioto and Miami, in the Ohio country, the Hinkstone and Lexington, Danville, Salt River and Shelby, Cumberland, Green River, Holston and Russell, wholly in Kentucky, and the New River circuit, part in Kentucky and part in Tennessee. ${ }^{7}$ None of these circuits as yet extended into Indiana, and there were no official Methodist societies in Indiana territory at this early date, but there was undoubtedly Methodist preaching conducted by local preachers, who had come into Indiana among the first settlers, previous to any officially organized society. I have named the circuits of the Kentucky district because it was from this district that Indiana Methodism sprang. The Kentucky circuit, which was the first circuit to include any Indiana territory, was the Salt River and Shelby.

In the year 1800 there was a great revival begun, which spread all over the western country, resulting in more than doubling the membership of the Western conference, and also greatly increasing the number of both local and traveling preachers. This remarkable revival made its appearance in Kentucky in the spring of 1801, at a Quarterly meeting held on the Hinkstone circuit. This meeting lasted from Friday until Monday morning, and preaching and exhortation was almost continuous during that time. One of the preachers at that meeting has told us that there "was a great trembling among the dry bones. Great crowds fell

name Western Conference, however, was not used in the minutes until 1801. the Western territory being designated as the Kentucky district or conference.

7 General minutes, Vol. I, 99. 
to the ground and cried for mercy, old and young." The next week another meeting was conducted on the Lexington circuit, in which "every local preacher and exhorter was employed, holding small meetings at various places on the circuit, and on Sunday morning all the people came together for a great meeting, and as they came they could be heard, singing and shouting on the road." With this beginning the work and enthusiasm spread into all the circuits of the Western conference, and Methodist work was also extended into many of the new settlements. ${ }^{\text {. }}$

The first reliable record of Methodist preaching in Indiana was in 1801 at a settlement called Springville, which was located in Clark's grant. Two local preachers, Samuel Parker and Edward Talbott, crossed the Ohio river and conducted a two days' meeting. ${ }^{9}$ This was evidently a part of the great revival movement which was then under way in the western country.

To William McKendree, the Presiding Elder of the Kentucky district, belongs the honor of establishing the first official Methodist class ever formed in Indiana. In the summer of 1802 Andrew Mitchell took William McKendree across the Ohio river in a canoe, and on this trip two classes were formed, in what is now Clark county, one at the town of Charlestown, the present county seat, and the other at a place called New Chapple." In the spring of 1803 Benjamin Lakin, then traveling the Salt River circuit in Kentucky, crossed the river and preached in the woods near the present town of Charlestown, as soon as the

\& Burke's Autobiography, 75-79.

9 From a letter of George K. Hester, found in Holliday's "Indiana Methodism," 37.

10 From a letter of 1 . N. Britton, a lifelong friend of Andrew Mitchell. The letter is found among the records of the Methodist church at Charlestown. Indiana. 


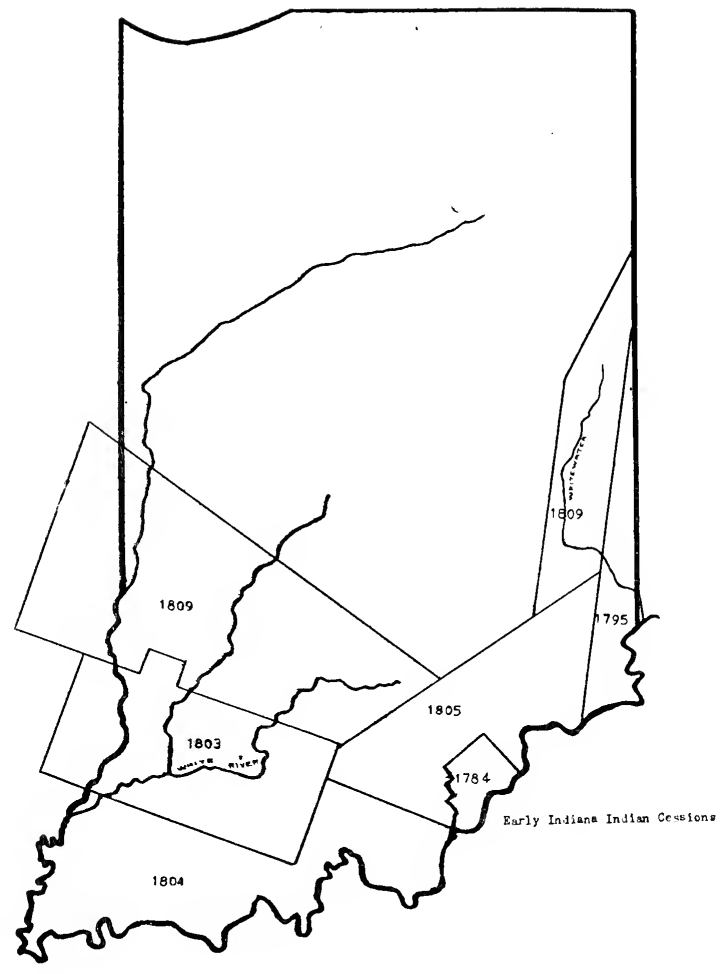



weather permitted, and made arrangements to include that neighborhood, and also the Robertson neighborhood, which was five miles north of Charlestown, among his regular preaching places, and these places remained a part of this Kentucky circuit until the organization of the Silver Creek circuit several years later. At the session of the Western conference, in 1805, Peter Cartwright was appointed as junior preacher with Benjamin Lakin, on the Salt River and Shelby circuit, and he states in his Autobiography that "Brother Benjamin Lakin and myself crossed the Ohio river and preached at Brother Robertson's and Prather's. In this grant we had two classes and splendid revivals of religion." 11

While Methodist preaching was being introduced into Clark's grant in the manner above described, others were introducing Methodist preaching in other sections of the new territory. The narrow strip of territory which had been opened to settlement after the Wayne campaign, in the southeast section, had become quite densely populated by 1805 ; especially was this true of the country along the Whitewater river. In 1805 two settlements had been formed on the east branch of the Whitewater, one a little south of the present city of Richmond, which was called the Kentucky settlement, because most of the families had come from Kentucky; the other settlement was above the present town of Brookville, and was called the Carolina settlement, because most of the families there had come from South Carolina. ${ }^{12}$ Among the settlers in the lat-

11 Peter Cartwright's Autobiography, 16i

12 Western Christian Advocate. August 15. 1445. Article by Allen Wiley. Rev. Allen Wiley, one of the well-known yioneer preachers of Indiana, contributed to the Western Christian Advocate during the years 1845-1846, a series of thirty-seven papers on the "Introduction and Progress of Methodism in South-easter'u Indiana." These papers form one of the important somress for this study. 
ter settlement were several Methodists, including James Cole, Benjamin McCarty, who had been an exhorter or local preacher in Tennessee, and Enoch Smith and his pious wife. These persons met together with some others and drew up a petition to John Sale, who was the Presiding Elder of the Ohio district, asking that a regular traveling preacher be sent them. In response to this petition in March, 1806, John Sale sent Joseph Oglesby to form a new circuit west of the Great Miami.

We are fortunate in having from Oglesby himself a description of the formation of this new circuit, which became known as the Whitewater circuit. $\mathrm{He}$ began his labors at the home of Moses Crume, a local preacher, living at that time near the present town of Hamilton, Ohio. His next stop was at the cabin of a family a few miles from Crume's by the name of Gray. After opening several preaching places in Ohio he struck General Wayne's old road from Hamilton to Ft. Wayne, which he says "seemed still fresh and plain." From this road he came upon an Indian trail which led him into Indiana, to the settlement above mentioned, the one known as the Kentucky settlement, near the present town of Richmond. Here he preached at the cabin of a Mr. Cox, where he formed a society. This society was small, because most of the people in this settlement were Baptists. The next preaching place was at McCarty's, more than forty miles down the Whitewater, seven miles above the entrance of that river into the state of Ohio. Here a flourishing society was formed. From McCarty's he went eleven miles down the river to the cabin of a Mr. Thomas, this class finally building a meeting house at Elizabethtown. From thence he went to the house of a Mr. Hays, between Elizabethtown and Lawrenceburg and formed another society. Oglesby also preached at Lawrenceburg, the county town of Dearborn county, on this first 
round, the town having been founded in 1802. From Lawrenceburg the preacher started north, up the Miami, preaching on both sides of the river, until he arrived at the place of beginning. ${ }^{13}$ This route was traveled by Oglesby every four weeks until the meeting of the Western conference, which was held that year in Tennessee, on September 15, 1806, and during his six months on this circuit he succeeded in gathering into Church membership sixty-seven persons.

Joseph Oglesby, the founder of the Whitewater circuit, was at that time a tall, slender, young man, in the prime of life. His hair, which inclined to be fair, was clipped short from the forehead half way back to the crown, and the remainder was allowed to grow eight or ten inches long, so as to reach down to his shoulders, and hung loosely about his neck. This peculiar method of hair dressing was recognized as the Methodist preacher fashion, and was quite generally followed by all the preachers. Oglesby's voice was a full bass and stentorian, but not harsh or grating. He had a great command of words and poured forth his thoughts and feelings with great volubility and zeal."14 The second year of the Whitewater circuit, (1806-1807) Thomas Hellums and Sela Paine were appointed as the circuit preachers. ${ }^{15}$ Hellums is described as "a grave, zealous, affectionate and weeping preacher." His countenance was always most solemn, "and his subjects of discourse were usually of a grave and pathetic cast. *** The intonations of his voice were as solemn as death, and

1:) Western Christian Arr., Octoler 17, 1845. In this paper Allen Wiley quotes from a letter of Joseph Oslesby, in which the above tincts are given concerning the founding of the Whitewater rirenit.

14 Western Christian Aal.. October 17. 184.

15 The year 1807 was the tirst rear a report from the Whitewater circuit apmears in the minutes and through a mistake it is called White Rivel cirruit instead of Whitewater. (Minutes, Vol. I, 149.) 
usually large tears dropped from his face most of the time while he was preaching."16 In this year Benjamin Lakin, whom we have met before, as one of the earliest Methodist itinerants to preach in Indiana, preached at a quarterly meeting held at McCarty's. During one of his sermons on a Sabbath, he suddenly paused and said in a most solemn manner, "I feel an impression that there is some young man or woman in this house, who will be tramping in hell before this time next year." Immediately, we are told by Allen Wiley, who was one of the young men present at that meeting, "all the young people whom I could see became deathly pale: and I suppose myself among the rest: for-I felt as awful as death, judgment and eternity could make me."17

Joseph Williams was the circuit preacher on the Whitewater circuit during the year 1807-1808, and that year many new neighborhoods were settled and taken in as preaching places, and the number of appointments on the circuit had increased to over twenty. Hugh Cull, a local preacher who had settled in the Whitewater country in 1805 and had done some preaching in the neighborhood, was employed to help Williams on the circuit, and at the close of the year the membership of the circuit was reported as 165 white and one colored. ${ }^{1 s}$

The first entire circuit in the territory of Indiana was the Silver Creek, which was organized in 1807 with Moses Ashworth as the circuit preacher. This new circuit took in Clark's grant, which had formerly been included within the Salt River and Shelby circuit of the Kentucky district. With the organization of this circuit, Indiana Methodism starts on its separate

16 Western christian Adr. November 2n, 1st5. Allen Wiley Paper Number Vi.

17 Hid., December 5. 1845. I'aper Number VII.

is Minutes. Pol. I, 15it. 
career. Moses Ashworth closed his first year with a camp-meeting, held in the Robertson's neighborhood, a few miles from Charlestown, and this was one of the first, if not the first camp-meeting to be held in Indiana. ${ }^{19}$ In the year 1808 a new district was added to the Western conference, and it received the name, Indiana district, and thus the name Indiana, appears on Methodist records for the first time. This new district had six circuits, namely: The Illinois, which included all the settlements in the great territory; the Missouri, another state-wide circuit; Maramack, Cold Water, and the two Indiana circuits, the Silver Creek and the Whitewater. ${ }^{20}$ Over this new district was placed as Presiding Elder, Samuel Parker, one of the local preachers who first introduced Methodist preaching in Indiana in the year 1801 .

In the year 1809 a third Indiana circuit was formed, the first report of which appeared in the minutes for 1810. This circuit was the Vincennes and the preacher appointed to preach Methodist doctrine in this Roman Catholic stronghold was William Winans. ${ }^{21}$ The story is told that one of the first services conducted by the circuit rider in the old town of Vincennes was held on a Sabbath evening at the fort, on the Wabash. The congregation was made up of a few government oficials, a few English speaking settlers, two or three Indians and the Governor of the territory, William Henry Harrison. There were only a few tallow candles to furnish light for the service, and one of these was held by the governor to enable the young circuit rider to read his text and line out the hymn.22 And it ought to be said, in this connection, that the first governor of Indiana territory, William Henry Harrison, was always

19 From the letter of Rev. Geo. K. Hester, as above.

20 Minntes. Vol. I, 171.

21 Ibid., 184.

22 Hollidiy. "Indiana Methodism," 28, 29. 
the firm friend of the Methodist circuit rider, though he himself was a communicant of the Presbyterian Church.

Belonging to the Vincennes circuit was a neighborhood known as the Busroe settlement, located on the Wabash, which was visited by Peter Cartwright in 1808, and in this settlement he organized a Methodist society, in the following manner, which we will allow him to relate in his own way: ${ }^{23}$

"I will state here a case which occurred at an early date in the state of Indiana, in a settlement called Busroe. Many of the early emigrants to that settlement were Methodists, Baptists and Cumberland Presbyterians. The Shaker priests, all apostates from the Baptist and Cumberland Presbyterians, went over among them. Many of them I was personally acquainted with and had given them letters when they removed from Kentucky to that new country.

"There was then no Methodist circuit preacher in that region. There was an old brother Collins, a local preacher, who withstood the Shakers, and in private combat was a full match for any of them; but he was not eloquent in debate, and hence the Shaker priests overcame my old brother, and by scores swept members of different churches away from their steadfastness into the muddy pools of Shakerism. The few who remained steadfast, sent to Kentucky for me, praying me to come over and help them. I sent an appointment with an invitation to meet any or all of the Shaker priests in public debate; but instead of meeting me they appointed a meeting in opposition, and warned the believers, as they called them, to keep away from my meeting; but from our former acquaintance and intimate friendship, many of them came to hear me. I

23 I'eter Cartwright saly's the second full circuit in the state of Indiana was the Vincennes circuit. which he himself helped to form in the mamner here described. "Autobiography," 167. 
preached to vast crowds for three hours, and I verily believe God helped me. The very foundation of every Shaker present was shaken from under him. They then besought me to go to the Shaker meeting that night. I went, and when I got there we had a great crowd. I proposed to them that we have a debate and they dared not refuse. The terms were these; a local preacher I had with me was to open the debate, then one or all of their preachers, if they chose, were to follow, and I was to bring up the rear." To this agreement the Shakers, however, failed to comply, for after the debate was under way, one of the Shaker priests, as Peter Cartwright calls them, called all the shakers present to disperse, but the sturdy circuit preacher then arose and called upon the crowd to remain, and succeeded in holdign a considerable number of them. He says, "When I arose to reply I felt a sense of the approbation of God, and that he would give me success. I addressed the multiude about three hours, and when I closed the argument, I opened the doors of the church and invited all that would renounce Shakerism to come and give me their hand. Forty-seven came forward and then and there renounced the dreadful delusion. The next day I followed those that fled; and I went from cabin to cabin, taking the names of those that returned to the solid foundation of truth, and my number rose to eighty-seven. I then organized them into a regular society and then next fall had a preacher sent them; and perhaps this victory may be considered among the first fruits of Methodism in that part of the new country.".".4

24 Peter Cartwright's Autoliography, 53-5.5. The shakers were a communistic sect otficially known as "The United Society of Believers in Christ's Second Coming." The shakers did not recognize marriage as a Christinu institution and considered it less perfect than the celibate state. They were very active in Kentucky, Ohio and Indiana for a number of years after $18(4)$. shaker communities were founded in Southern Indianat, among 
Much of the preaching of the circuit riders was of a controversial character, largely due to the fact that Methodism was misunderstood and preached against by other denominattions, and the Methodist itinerant felt called upon to defend his teaching. A Baptist who overhearing a conversation concerning the Arminian magazine said he had always understood the word Arminian to mean one who trusted in the arm of flesh for salvation, and he stated that he did not know that Methodism believed and taught "free grace." Many thought that Arminian meant the same as Arianism," which misconception led to bitter attacks upon Methodism. But undoubtedly the controversial character of the preaching was one of the things which attracted people to the Methodist meetings, because most people enjoy denunciations.

In the fall of 1810 the Whitewater circuit was divided, the lower part receiving the name of Enon circuit, which was a Scriptural name meaning abundance of waters, and this new circuit was well described by this name, for there were twelve creeks to be crossed .by the preacher in his rounds of the circuit, and many times he was compelled to travel many miles out of his way, over high and steep hills, and at this time there were no roads and few paths to guide him on his way. This name Enon was rather too vague, however, for it meant nothing to the average person, and the next year the circuit name was changed to Lawrenceburg. ${ }^{26}$ The first circuit preacher on the Enon circuit was Walter Griffith, who was a young man, in the prime of life, and full of zeal. And indeed all of the pioneer preachers in Indiana were young men. Griffith found an excellent helper on the circuit, in the person of Elijah Sparks, a

them this community at Busroe on the Wabash. The Methodist rircuit riders were deadly foes to this delusion.

25 Western Christian Adrocate, December 19, 1845.

26 Western Christian Adroente, December 19, 1845. 
lawyer living near Lawrenceburg, who had formerly been a traveling preacher, but on his marriage, had located, for in those days, to marry was equivalent to ceasing from traveling. Sparks had moved to Indiana from Kentucky in 1806 and until his death in 1815 he was one of the most popular preachers in Indiana, especially at camp-meetings. In those days there was great prejudice against lawyers and many thought a lawyer could not be a christian, but Sparks succeeded in overcoming this prejudice, although he continued to practice law and preach at the same time. In 1814 he was appointed Judge for the third circuit of Indiana territory, which he held until his death, the following year. ${ }^{27}$

In 1811 there was a division of the Vincennes circuit, the Patoka circuit being created in the southwest corner of the territory. The territory of this new circuit mostly lay along the Patoka river. ${ }^{2 s}$ The year 1811 was a notable one in the history of the territory of Indiana, and also in the history of Indiana Methodism, for it was in the fall of this year that the battle of Tippecanoe was fought and won by General Harrison, and it was also the year of the great earthquake. These quakes were of the most severe kind and continued during most of the winter of 1811 and 1812 . The effect of these shocks upon Indiana Methodism and religion in general is thus described by an eyewitness: "As a result of the continued quakes the whole country became alarmed and the most vile and hardened sinners began to tremble and quake, and go to meeting, and weep and pray. Now every preacher traveling and local, with the exhorters began to hold meetings with more earnestness than ever, in almost all directions, and Baptist ministers did the same, and it seemed as if almost everybody would become religious that winter

27 Ibid., October 24. 1845.

28 Minutes. Vol. 1, 211. 
and spring. Some men were converted and became preachers, whose conversion I had been in the habit of regarding as almost as hopeless as the conversion of the devil himself. There was one man by the name of William Ramsey, whom I had regarded as the most profane and wicked man I ever knew, who became as tame and timid as a lamb. A few months afterward he was soundly converted, he became a useful preacher and continued so for years, while he remained in our part of the country." 29

The success of this year, largely due to the earthquake, was very great, and there was a large ingathering of members. The Whitewater circuit increased from 567 to 843 , an increase of 276 ; the Lawrenceburg circuit increased from 306 to 480 , an increase of 174 ; the increase in the Silver Creek circuit was from 375 to 555 ; while the Vincennes circuit was divided, probably as the result of the great increase in members and preaching places. This great increase throughout the circuits of Indiana, however, proved to be an unhealthy growth, and the next year there was a reaction, resulting in a considerable loss both of members and zeal, and we are told that it was some years before the Church was as healthy and vigorous as it was formerly..$^{30}$

Another cause of the decrease in membership following the year 1811, was the breaking out of the War of 1812. The alarm of war drove many of the settlers to the block houses, because of the growing hostility of the Indians; while a considerable number of the frontiersmen entered the service of their country as volunteers, and the work of the circuit riders was hindered materially.

In 1812 the Whitewater circuit was again divided, the part east of the present town of Brookville was

29) Westem Christian Advocate, January 9, 1846.

30 Minutes, Vol. I, 209, 211, 227. 
called the Oxford circuit, part of which lay within the state of Ohio. The circuit embraced much of the present Franklin county, the whole of Union county, the settied parts of Wayne county and perhaps a part of Fayette county. ${ }^{31}$ The first preacher on this new circuit was Moses Crume, one of the most useful of all the early Indiana preachers.:-2 Like so many of the other early Indiana preachers, Crume was a native of Virginia, moved to Kentucky and from there came to Ohio, and later to Indiana territory. In the course of his career as a Methodist itinerant he travelled from Madison, Indiana, to Urbana, Ohio, and from the Miami to the western line of Indiana. $\mathrm{He}$ has been described as resembling Washington in appearance. He was never a popular preacher, due to his lack of voice and energy in the pulpit but his sermons were always sound and good, and was a thorough student for those days, and was familiar with all the current theological discussion. He always carried Canno's marginal Bible with him and it was filled with marks from Genesis to Revelation. $\mathrm{He}$ was thoroughly familiar also with the doctrine, usages and discipline of the Methodist Church, and was a most firm and just administrator.

The preacher on the Whitewater circuit during the first year of the war of 1812 was John Strange, who was an extremely popular and talented itinerant. During this year he traveled from block-house to blockhouse with his gun on his shoulder, to defend himself from the Indians, and on one occasion while on his rounds, on reaching one of the block-houses and learning that all its occupants were unharmed since his last visit, he started up the hymn:

"And are we yet alive and see each others face?"3.3

31 Western Christian Adrocate. February 20, 1846.

32 Ibid., January 30, 1846.

33 Ibid., February 20, 1846. 
In 1812 the Western conference was divided into the Ohio and Tennessee conferences and the Indiana circuits were divided between them; the circuits in the southeastern corner of the territory were included in the Ohio conference, while those in the southwest section were in the Tennessee conference. The circuits were divided among three districts, the Miami and Salt River districts of the Ohio conference and the Wabash district of the Tennessee conference. There were very frequent changes made in the circuits and districts, and for that reason it is difficult to follow them, through several years. For instance, the Wabash district appears only in the reports for 1812 and 1813, and never appears again; Patoka circuit, started in 1811, disappears the two following years and again appears in $1814 .^{34}$

Among the early Indiana Presiding Elders, were John Sale, Samuel Parker, Soloman Langdon, Learner Blackman, William Burke, James Axley, James Ward, Peter Cartwright, Charles Holliday and Jesse Walker. ${ }^{35}$ Altogether they were a remarkable group of men, and every one of them is worthy of a permanent place in the history of the great state of Indiana. The Jesuit Fathers, in the days of exploration on this continent, undertook no greater task than the task which was undertaken by these rude, but earnest and upright frontier preachers. The circuit riders were no less devoted and many times as well qualified to preach, as were the Presiding Elders. In fact there was very little distinction made between the Elder and the traveling preacher, and many of the early preachers in Indiana became presiding elders.

John Sale was the Presiding Elder of the Ohio district at the time of the formation of the Whitewater circuit, and he and William McKindree were therefore

34 General Minutes. Vol. I. 216-2s7.

35 Ibid. 


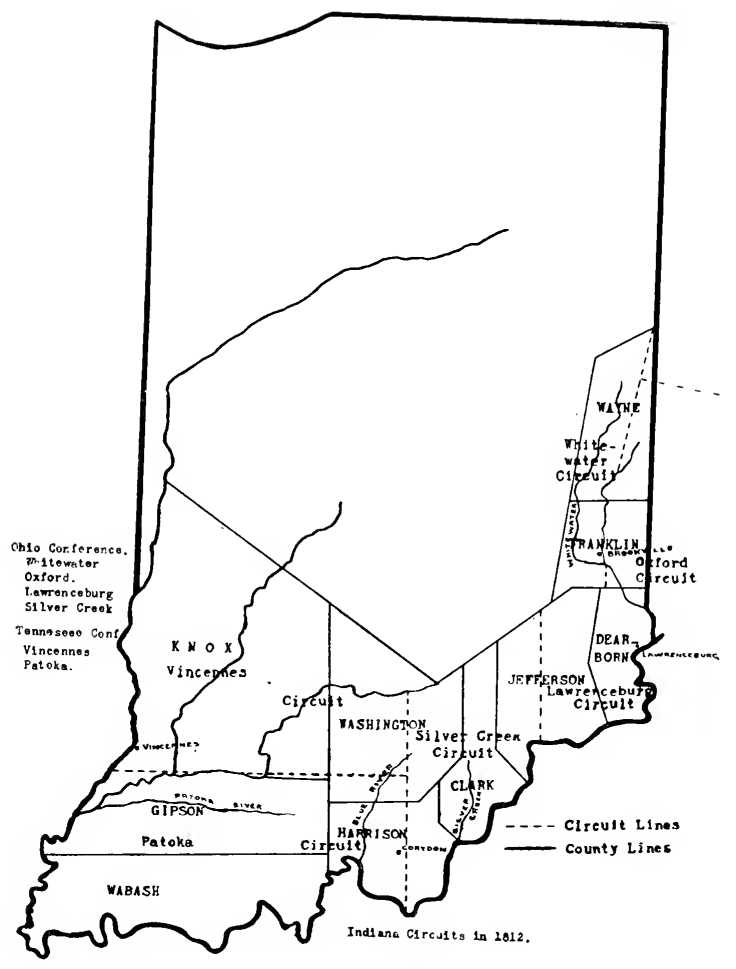



the first Indiana Presiding Elders. Sale was a Virginian by birth, was received on trial into the ministry of the Irethodist Church in 1796, and traveled his first circuits in Virginia and North Carolina. In the year 1800 he was sent to the Kentucky circuit, in 1802 he traveled the Scioto circuit in Ohio; in 1803 he was appointed to the Miami circuit, also in Ohio; in 1804 he again served a circuit in Kentucky, and was made Presiding Eicier of the Ohio district in 1805. At that time the Ohio district was probably the largest district in Methodism. It embraced a part of Virginia, all the settled parts of Ohio, and after the spring of 1806 the southeastern part of Indiana. He traveled this district three years, when in 1808 the district was divided, the western part being called the Miami district, which he served two years. The next four years he traveled the Kentucky district, then two more years he was on the Miami district and from 1816 to his death, in 1826, he served circuits in Ohio.

John Sale married while on the Ohio district and was one of the first two married traveling preachers in the western country. The other of the earliest married preachers was William Burke, who was Presiding Elder of the Green River district in 1810 when it included the Silver Creek circuit. Bishop Asbury discouraged marriage among the preachers, knowing the increased hardships marriage would bring to the preachers themselves, but especially to the preachers' wives. For this reason many of the pioneer preachers ceased to travel, as the active ministry was termed, while they were still young men, simply because they married, and were advised to locate; that is, they settled down on a farm, generally, or entered some other profession though they did not cease to be preachers or members of the conference. At this early time sixtyfour dollars was the amount allowed a traveling preacher, and he must provide in most cases his own horse 
and equipment, such as saddle and saddle-bags, and in few cases did he receive all he was allowed. William Burke says, that after his marriage, "I met with every discouragement that could be thrown in my way. People and preachers said, 'You had better locate.' I shared equally with the single men when they were on the circuit with me, in order to keep peace. *** One winter I had to use a borrowed blanket instead of a cloak or overcoat." By 1810, however, it became much more common for preachers to marry, though all were not as successful as they might have been in selecting wives suitable for a circuit rider. In 1811 a junior preacher by the name of Homes was sent to aid Moses Crume on the Whitewater circuit. Homes was married and his wife traveled, for the most part, with him on the circuit. She was an incessant smoker, and her husband would be compelled to stop frequently at the cabins to light her pipe. Naturally this particular preacher's wife soon became most unpopular on the circuit, not only because of her smoking, but because of her sharp and cutting comments, concerning the food and lodging at the various cabins where they were entertained.

In appearance John Sale was a heavy, medium sized man, and very neat in his dress. He was possessed of a large share of good, strong common sense, and was particularly careful to regard the decencies of public worship, and would suffer nothing that was extravagant in religious assemblies, if he could hinder it. I have found, indeed, common sense to be one of the characteristics of the early Methodist pioneer preacher although it has been the popular conception that the Methodist circuit rider courted religious extravagances and thrived upon them. Sale was also a strict disciplin-

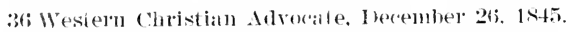

:37 Burkes's Autobiograyhy, 91.

3N Westorn ('hristian Adromte, December 26, 1845. 
arian, and was always careful to see that Methodist usages were enforced. From 1810 to 1820 there was a great controversy among Methodist preachers, concerning infant purity and innate depravity, and for a time it seemed that it would result in splitting Methodism on the frontier into two camps, but Sale, always a kind and zealous peace-maker, was largely instrumental in healing the dispute. Allen Wiley says that "perhaps Methodism in much of Ohio and Indiana is more indebted to John Sale for its symmetry and beauty than to any one man on earth or in heaven." 39

Soloman Langdon, who served a number of years as Presiding Elder of the Miami district, when that district included three of the southeastern Indiana circuits, was a New Englander by birth, and began to preach in his native section in 1800 . He came west in 1807, served several circuits in Ohio, and was appointed Presiding Elder of the Miami district in 1810. In appearance he was a tall, noble man, and had great gravity and dignity "in all his ministrations." Wiley says, "He was a good successor to John Sale, not similar except in good sense and piety. They were both men well calculated to give stability and perpetuity to Methodism in a new country." Langdon was not an emotional preacher, but he was a "sound and talented man, and did much to disabuse the public mind of misconceptions concerning Methodism." $\$ n$

Peter Cartwright's connetction with Indiana Methodism was limited to the year he served on the Salt River and Shelby circuit in Kentucky in 1805, when he crossed the Ohio River and preached in Indiana, to his visit to the Busroe settlement in 1808 when he put the Shakers to flight, and to the year 1812-1813, when he served as Presiding Elder of the Wabash district, which included within its bounds the Vincennes and the Pa-

39 Western Christian Adovcate, January 16, 1846.

40 Ibid., December 26, 1845. 
toka circuits. It is unnecessary to give an extended account here, of this perhaps the most famous of all Methodist frontier preachers. His Autobiography, which reads like a veritable fairy tale, is still sold and read by thousands, and through that medium his fame has gone far beyond the bounds of the Methodist church.

James Axley, who was the Presiding Elder on the Wabash district in 1811-1812, was one of the peculiar and interesting characters to be found among the early preachers in the western country. He was a man of little education, but was genuine, and tremendously effective in his work. He seemed to be afraid of nothing, except sin, and yet he was as teachable as a child. On one occasion when Peter Cartwright and he were dining at the home of the Governor of Kentucky, among other things on the table before them was fried chicken, and Axley, who had evidently had little experience with table etiquette, called the family dog to his chair and threw the chicken bones on the carpet for the dog to eat. When they went to their room Cartwright rebuked him for his bad manners, and so mortified was Axley because of his ignorance, that he actually wept. ${ }^{41}$ On another occasion Axley was preaching in a private house with a chair before him for a pulpit, when two young ladies came in and sat just in front of the preacher. The young ladies had on dresses with short sleeves and low necks, for such things were fashionable then as now. Axley had a large bandanna handkerchief on the back of his chair, and he paused in the service and handed the handkerchief to the young ladies with the request that they would cover their bosoms. ${ }^{42}$

Axley was very strong in his opposition to slavery and whiskey, as indeed were most of the frontier

41 Cartwright's Autobiograjhy.

42 Rev. Joseph Tarkington's Autobiography, 74 . 
preachers, at this date. After he ceased preaching, and located, he made his living and supported his family by farming, and he was wont to testify on all proper occasions, that "his logs were rolled, his house raised, and his grain cut without whiskey; and though he had plentyful crops of corn, not the first track of a negro's foot was ever seen in one of his fields." 43 On one occasion Axley was discoursing on the conformity to the world among Christians, particularly in fashionable dress and manners. In his address he held a sort of a colloquy with an imaginary apologist, seated at the other end of the congregation. The pleas and excuses of this imaginary person were given in an altered tone of voice, and then assuming his natural voice he would reply. "But sir," his imaginary man says, "some of your Methodist preachers themselves dress in fashionable style, and in air and manner enact the dandy."

"O no, my friend, that can not be. Methodist preachers know their calling better. They are men of more sense than that, and would not stoop so low as to disgrace themselves and the sacred office they hold by such gross inconsistency of character."

"Well, sir, if you won't take my word for it, just look at those young preachers in the pulpit behind you."

Axley then in seeming surprise turned around and facing the two or three rather fashionably dressed junior preachers seated in the rear of the pulpit, surveyed them from head to foot for several minutes, while they quailed under his keen glance. Then turning around to the congregation, and leaning a little forward with his arm extended and his eyes fixed on the supposed apologist at the back of the room, he said

43 Finley, "Sketches of Western Methodism," Chapter XVI. 231-246. Rev. J. B. Finley in this book gives sketches of a number of early Indiana preachers. Among them are short biographies of Benjamin Lakin, John Sale, Samuel Parker, Learner Blackman, James Axley, Joseph Oglesby, John Collins and John Strange. 
in a subdued voice. "If you please, sir, we'll drop the subject."

The Presiding Elder par excellence in early Indiana Methodism was Samuel Parker, especially from the standpoint of eloquence. He was the Presiding Elder appointed to take charge of the new Indiana district, at its formation in 1808, and served as the Presiding Elder of the Miami district in 1811. He was a native of New Jersey and began to preach in 1800, though he was not admitted to membership in the Western conference until 1805. His first circuit was the Hinkstone in Kentucky, and he served various circuits in Kentucky and Ohio until 1808, when he became Presiding Elder of the new Indiana district. Later he was appointed to a similar ofice in the Miami district, and in 1815 he was made Presiding Elder of the Kentucky district, which he held four years. At the end of that time he was sent to Mississippi to take charge of the new work there, but his career was soon cut short by his untimely death in 1819. Samuel Parker is a good example of the itinerant who literally burned himself out in the service of the Church. ${ }^{43}$

Parker was a tall, slim, awkward man, with large blue eyes and an enormous Roman nose. He had a long chin which he used in the winter time to hold up the blanket which served in lieu of a great coat. A hole was cut in the center of the blanket, large enough to let his small head through, and when it was bitter cold, he would hang the forepart of the hole on his chin and bid defiance to wind and cold. And when his bed covering proved not sufficient, his blanket was made to serve for that purpose, and it was frequently brought into use, for bed covering was scant, especially at Quarterly meeting. There were few churches in those early days and quarterly meetings were held at private cabins, and on those occasions they would be crowded with strangers. When bed time came the "sisterhood" 
took the beds while the men would "pile down on the floor by the dozen," and with feet extended to the fire, would sleep soundly until the morning.

Let us picture this homely, awkward frontier preacher, clad in ill nitting, homespun preacher garb,for there was a well recognized preacher garb then as now,-as he conducts the preaching in one of these rude cabins on a quarterly meeting occasion. He places his chair before him as his pulpit, and begins to read a hymn, in a soft and charming voice. After the singing of the hymn, comes the prayer, which is uttered with such eloquence and pathos "that heaven and earth seemed in juxtaposition." And then follows the sermon on the text, "The upright love thee." One who was present on such an occasion and heard this very sermon says, "I have since heard the most able divines in the country, but his description of the good man's love to God and God's love to man, I have not been privileged to hear equaled since, and indeed I never expect to hear anything this side the throne of God which will surpass it." 44

The camp-meeting, however, was the place where the early Methodist preacher had the best opportunity to display his powers in the pulpit. It was customary for a camp-meeting to be held on each circuit at sometime during the summer months, and at such meetings several preachers from adjoining circuits, and sometimes preachers from a distance would be present. The first camp-meeting held in Indiana was probably the one conducted in the Robertson neighborhood, in the vicinity of Charlestown in the summer of 1807 . In 1808 there was a camp-meeting conducted on the Whitewater circuit, and after this date we have records of many Indiana camp-meetings. In 1810 there were two camp-meetings conducted on the Whitewater cir-

44 Memorial sketch of the Iife of Samuel Parker. Minutes, Vol. I, 358, 359. 
cuit. At one of these meetings the wife of a local preacher, Jeremiah Meek by name, became ecstatic and continued in this state for about three weeks, during which time she scarcely ate, drank or slept. This was too much for her nerves and it resulted in the unbalancing of her mind, and she remained so for many years. At the other camp-meeting, held on this circuit in 1810 , there were five preachers present besides the regular circuit preachers, and we are told by one who was present, that this meeting made a "powerful impression in favor of religion in general and Methodism in particular." 45

In 1815 two new Indiana circuits were added to the six already in existence, the Wabash and the Blue River circuits. The Wabash circuit was in the southwestern corner of the state just below the Patoka circuit, and the Blue River circuit was situated along the banks of that stream, just to the west of the Silver Creek circuit. ${ }^{46}$ It is interesting to note that all the Indiana circuits, up to 1816 , were named after streams with the exception of the Vincennes and the Lawrenceburg. The reason for these names is obvious. The early settlements were along the rivers and creeks, and these streams and the valleys served as the natural highways for the new country, and the circuit naturally derived its name from the stream along which the cabins of the settlers belonging to the circuit, were located. There were in those days few towns or post offices after which circuits might be named, and when finally towns of some importance did come into existence, the circuits soon came to bear their names. This naming of circuits after streams was not in any sense peculiar to Indiana, but the same practice was followed all over the western country. The Blue River circuit was in the Salt River district of the Ohio conference, while the

45. Western Christian Adrocate, March 6, 1846.

46 Ibia.. December 19. 1845, December 5, 1.845. 
Wabash circuit was placed in the Illinois district of the Tennessee conference. The first circuit preachers on these new circuits were James Simmons for the Blue River circuit and Daniel M'Henry for the Wabash.

At the beginning of Indiana Methodism there were of course no meeting houses, but in the winter time the cabins of the settlers were the temples, and in the spring, just as soon as it became warm enough, the people worshipped out under the trees. It was not long, however, before log meeting houses began to be erected, for there was plenty of material, and a Methodist revival generally resulted in providing willing hands to erect the desired house of worship. The men "were skillful with the chopping ax, the broad ax, the maul and wedge, the frow and whip saw, and the woods were full of tall and straight-boled beeches, maples and ash trees with a fair sprinkling of straight-grained white oaks and poplars. All the men had to do in order to have a meeting house was to go into the forest and cut, hew, split, rive, whip-saw and build-and they did it." ${ } i$ When the day for raising the house came round a general invitation was sent out and volunteer help came from all quarters. Any man was considered a very mean one indeed who did not give muscular aid on such an occasion. Thus were the first Methodist meeting houses erected in Indiana, and they soon began to rise up in all the circuits. During the first year on the Silver Creek circuit three such meeting houses were erected. One of the first meeting houses to be erected on the Whitewater circuit was the Meeks meeting house, located on Clear creek, a mile and a half northeast of the present town of Salisbury. This meeting house was erected in 1808. In 1809 the Cain meeting house, a few miles north of Richmond, was erected, and in 1810 a third meeting house was built at the little town of Boston. The Cain meeting house was dedicated

47 General Minutes, Vol. 1. 2\$2. $2 \$ 3$. 
by Rev. John Summerville, who preached from the text, "Out of him came forth the corner, out of him the nail, out of him the battle bow, out of him every oppressor together." In these log meeting houses there were none of the comforts known to modern churches, and the exterior and interior was rough and rudely finished. The roofs were made of clapboards, held on by weight poles; the floors were of puncheons; the chimneys of sticks and clay, while the seats were split logs hewn smoothly with an ax. The pulpit was a box-like structure made of riven boards, often of oak, smoothly shaven with a drawing knife. ${ }^{49}$

American Methodism in the year 1816 sustained a great loss in the death of Bishop Francis Asbury, who died on the 31st of March of this year.50 To him more than to any other, is due the honor of being called the father of American Methodism. He came to America in 1771, saturated with Wesley's thoughts, and resolutely determined to carry out Wesley's plan. Instead of settling down in the centers of population, he heard and heeded the call of the wilderness, and himself setting the example, he sent his preachers through the forests and over the mountains to take the Gospel to the far flung outposts of civilization. "For nearly fifty years he was the outrider of an ever-growing army of apostolic men who knew neither self nor fear, who conquered a continent and covered it with a network of circuits and conferences.".1 Although Methodism in Indiana was not founded by Asbury, personally, yet it was his spirit which fired the hearts and

4S Judge David D. Banta. "Making a Neighborhom." 17-1h. From "Readings in Indianal History". 295-297.

49 W. C. Smith, "Indiana Miscellany." 62-70.

50 Biographical sketch of Francis Asbmry. (ieneral minutes, Vol. 1. $272-274$.

51 The Journal of John Wesley, edited ly Nehemial r curnock. Vol. VI, 2. Elitor's comment. 
inspired the deeds of the McKindrees, and Sales, and Parkers and all the others.

By 1816 there were eight circuits in Indiana with a total membership of 2,699 whites and eight colored. The colored members were found only on the Silver Creek and Lawrenceburg circuits. These eight circuits were divided among three districts; the Whitewater, Lawrenceburg and Oxford circuits were in the Miami district; the Silver Creek and the Blue River circuits were in the Salt River district; while the three southwestern circuits, the Vincennes, the Patoka and the Wabash were in the Illinois district of the Tennessee conference. The Miami and the Salt River districts were in the Ohio conference.

List of Indiana circuits, with circuit preachers and presiding elders hy geitrs, to 1816 :

1406-Whitewater Circuit: James Oslesby, cirwuit preacher ; John sale, presiding elder.

1sot-1so7-Whitewater: Thomas Hellums aud Sela Paine, preachers, John sale, presiding elder.

1so7-1808-Whitewater: Joseph Williams, preacher, John Sale, presiding elder. Silver Creek: Moses Ashworth, preacher; William Burke, presiding elder.

1808-1809-Whitewater: Hector Sanford and Moses Crume. preachers: samuel Parker, presiding elder.

Silver Creek: Joseph Crawford, preacher: simuel Parker, presiding elder.

1so9-1s10-Whitewater: Thonias Nelson, samuel H. Thompson, preachers: John Sale, presiding elder.

Silver Creek: Sela l'aine, preacher: William Burke. presiding elder.

Vincennes: William Winaus, preacher; Sanuel Parker, presiding elder.

1810-1811--Whitewater: Moses Crume, preacher; Soloman Langdon, presiding elder.

Silver (reek: Isaac Lindsey, preacher: Willam Burke, presiding elder.

Vincennes: Thomas Stilwell, preacher: Learner Blackman. presiding elder.

Euon: Walter Griffith, preacher; Soloman Langdon, presiding elder. 
1811-1812-Whitewater: Robert W. Finley, preacher; Soloman Lingdon, presiding elder.

silrer Creek: William McMehan, preacher; James Ward, presiding elder.

Vincemnes: Jacob Turman, preacher; James Axley. presiding elder.

Patoka: Benjamin Edge, preacher: James Axley, presiding elder.

Euon or Lawrenceburg: Walter Griffith, preacher: Soloman Langdon, presiding elder.

1812-1813-Whitewater: John Strange, preacher; Soloman Langdon, presiding elder.

silrer Creek: Thomas Nelson, preacher; James Ward. presiding elder.

Vincemmes: Richard Richards, preacher; Peter Cartwright, presiding elder.

Patoka: Onitted this year.

Lawreuceburg: William Dixon. preacher; Sanuel Parker, presiding elder.

Oxford: Moses Crume, preacher; Soloman Langdon. presiding elder.

1813-1s14-Whitewater: David shar, preacher: Samuel Parker. presiding elder.

silver Creek: Charles Harrison, preacher; Charles Holliday, presiding elder.

Vincennes: Zechariah Witten, preacher; Jesse Walker. presiding elder.

Patoka: Omitted this year.

Lawrenceburg: Moses Crume, preacher: Samuel Parker, presiding elder.

Oxford: John Strange, preacher; Samuel Parker, presiding elder.

1814-1815-Whitewater: William Hunt, preacher: Samuel Parker. presiding elder.

Silver Creek: Shadrach Ruark, preacher: Charles Holliday, presiding elder.

Vincennes: John Schrader, preacher: Jesse Walker, presiding dealer.

Patoka: John Scripps, preacher; Jesse Walker, presiding elder.

Lawrenceburg: John Strange, preacher: John Sale. presiding elder.

Oxford: John Summerville, preacher: John Sale, presiding elder. 
1815-1s16-Whitewater. Daniel Fraley, preacher; John s:ıle, pre siding elder.

silver creak: Joseph Kinkaid. preacher: Chatrles Holliday, presiding elder.

Vincemes: 'Thomals Datis, preacher: Jesse Wallker, prexiling older.

Patoka: Thomas A. King, preacher: Jesse Walker. presiding elder.

Lawrenceburg: David Sharp, preacher: John Sale, presiding elder.

Oxford: Benjamin Lawrence, preacher; John Sale, presiding elder.

Blue liver: John Simmons, preacher: Charles Hollidisy, presiding elder.

Wabish: Danjel MeHenry, preacher; Jesse Walker, presiding elder. 
CHAPTER II.

INDIANA METHODISM, 1816-1832.

IN 1816 Indiana's star was added to the American constellation. As early as 1812 a petition had been drawn up and presented to congress, asking that Indiana be made a state. ${ }^{1}$ Nothing was done at this time, and it was not until February, 1815, that a petition from the inhabitants of Indiana Territory, asking for admission into statehood, was brought before the House. During the summer following this petition, there was much agitation throughout all the Territory. Newspapers published accounts of new town sites which were being laid out, and statistics were gathered (though there is doubt as to their authenticity) stating that the population was 63,897 . The Enabling Act had appointed May 13, 1816, as the time for the election of delegates to the Constitutional Convention. The only restriction as to the work of the convention was that the constitution should exclude slavery, the same restriction which had been laid down in the Ordinance of 1787 . Methodism was represented in this convention by Hugh Cull from Wayne county, and Dennis Pennington, of Harrison county." Both were interested in politics as well as religion and exercised a strong influence on the convention.

From this time there was a rapid increase in the population. The immigration was still chiefly from

1 Esalrey, History of Indiana. Chat). IX.

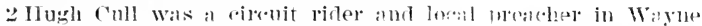
county. Allen Wiley silys that he was the first Methodist in that county. Dennis P'ennington was not a preacher hut was a ploninent layman and later served a number of years in the state Legislature. Hollday. Indiana Nathorlism. ('halpter 1. 
the Carolinas, Tennessee and Kentucky, though a number of settlers from the Western part of New York and the Northwestern section of Pennsylvania were forced into Indiana because of economic causes, during the early part of 1817 . The summer of 1816 had been cold and the supply of grain was consequently limited. As a result of this condition many people floated down the Alleghany and Ohio rivers on rafts and settled in Dearborn, Jennings, Switzerland and Washington counties. These people were much interested in politics, and while during the period of territorial government, the offices had usually been filled by Virginians, from 18161824 the government was more frequently in the hands of settlers from Pennsylvania. There were several settlements directly from Europe, such as the Swiss at Vevay, but none became strong enough to exert an active influence in politics. ${ }^{3}$

One noticeable fact in regard to church, and particularly Methodist history in Indiana, is that the first societies, as a general rule, were formed in the country. In many of the towns, the property holders and office seekers were opposed to all forms of religion. Among the early settlers in Indiana were "criminals from the east and others of criminal tendencies, who found the restraints of the law disagreeable." This class took up its headquarters in the villages and about the village taverns. ${ }^{*}$ This fact made the village an unprofitable field, while those who settled in the country districts were more easily influenced by religious teaching. The moral impress of the first settlers remains in many towns to this day. In some cases, the proprietor of the town, the clerk of the court, or the landlord of the tavern gave tone to the morals of the community. In other cases some man of wealth or some family of culture made an impress that was abid-

3 Holliday, Indiana Methodism, Chapter V.

4 Readings in Indiana History, 294. 
ing. Brookville, Charlestown, Corydon, Bloomington and Indianapolis were fortunate in this respect, for their early and most influential citizens were usually religious, or recognized that respect was due to religion, and that its influence on society was decidedly helpful, and they endeavored to promote its advancement. But we must give credit to some less worthy methods of promulgating religious influence. The barroom was often the first place thrown open for preaching in a western village, and the landlord would pride himself on maintaining good order during the service." The first sermons preached in Rising Sun and New Albany were in bar-rooms. A sermon preached by James Conwell, of Laurel, led to the conversion of a tavern-keeper, who disposed of his liquors and opened his bar-room for preaching, and it remained the permanent place of worship until the erection of the village church.

In 1816 a readjustment was made by which southwest section of Indiana was to be included in the Missouri conference, which had been organized that year, holding its first session in Turkey Hill Settlement in Illinois." The Indiana circuits were in the Illinois District. The boundaries of this new conference extended into four States and Territories-Indiana, Illinois, Missouri and Arkansas. At the sessions of the two conferences, containing Indiana circuits, in 1818 we find the following adjustment of Indiana circuits: Ohio Conference, Lebanon District, contained Whitewater circuit, Miami District, Lawrenceburg, Madison and Oxford circuits. Missouri Conference Illinois District, contained Indian Creek, Blue River, Harrison, Vincennes, Patoka and Pigeon or Little Pigeon, and

5 Holliday, Indiana Methodism, 99.

fiminutes of Conference, Vol. I, 1773-15.23. 1. 297. "Life and Times of Rev. Allen Wiley," F. C. Holliday, 51-52. Seven member's were present at the first session of the Missouri Conference over which Bishop IIKendree presided. 
it is also probable that the Wabash circuit was within the bounds of the state.

From 1815 to 1820 was a period of increased settlement and of greater development in the sections already settled. With the increase in population the value of property also increased. In 1820 a malarial fever epidemic in the southern section of the state, particularly on the lower Wabash, checked immigration, and many left that region and settled further north. The growth of Methodism had kept pace with the growth of population. By 1817 it was found that the church had completely overcome the great loss in members caused by the war with Great Britain in 1812-1814. The year 1817 showed an increase of 849 members over the preceding year, and 580 over the number before the war began. In 1810 the population of Indiana was 24,520 and Methodism numbered its members at 755 . In 1820 the population of the State had increased to 147,178 , and Methodists to $4,410 .^{\top}$

In 1820 Indiana was still divided between the Ohio and Missouri conferences; the five circuits, Lawrenceburg, Whitewater, Greenville, Oxford and Madison being in the Ohio Conference, Miami District, while in the Missouri Conference an Indiana District had been created and contained the following circuits: Charlestown, Blue River, Bloomington, Vincennes, Patoka, Ohio, Mount Sterling and Corydon. ${ }^{8}$

This table of the increase of membership, and circuits, so briefly given, cannot tell of the hardships endured, and the trials encountered, by the circuit rider. The itinerant system was peculiarly adapted to the time and country. It effectually prevented preachers from forming local ties, or creating local prejudices, which might have injured their effectiveness. The

7 Statistics from Holliday, Indiana Methodism, 51.

8 Minutes of Conferences, Vol. I, 367 . 
poverty which accompanied it kept them foot-loose of all worldly things. It might be compared in some ways, to the Jesuit system of missionary work, and certainly it was as effective as the work of the Catholics among the Indians and half-breeds. While the communities to which the itinerant preachers came might be rude and illiterate in some ways, still, there were the germs and possibilities for future growth and development, which had been entirely lacking in the Indian villages of an earlier period. The preaching of these devout men-and devout men they were in the truest sense-was a great moral and educational force. Even when it influenced men's minds through fear, it prompted them to good conduct, as one of the necessary means of keeping out of the "eternal hell of quenchless fire." True enough, the preachers themselves were men of little education, but they knew thoroughly the messages they were to deliver and they were very much in earnest. Their speech might be ungrammatical at times, but their zeal was white hot with the fervor of conviction and their eloquence lost nothing in effectiveness by reason of rudeness in rhetoric or inaccuracy of diction.

We picture the typical itinerant of that day as a "tall, rawboned, hollow-eyed man, who dressed according to the Methodist preacher fashion of that day, namely, round-breasted coat, long vest with corners cut off, short breeches and long stockings, with his hair turned back from about midway between the forehead and the crown, and permitted to grow down to the shoulders."' One who saw Bishop William McKendree near Washington, Indiana, on his way to the Missouri Conference in 1822 or 1823 describes him as wearing short clothes. His coat had a high-rolling collar, a long and very sharp tail, with large brass buttons on

9 One of the early itinerants as described by Allen Wiley. 


\section{1}

it. ${ }^{10}$ But the circuit rider was by no means so well dressed as a Bishop, who commanded the munificent salary of perhaps $\$ 300$ a year, if he could collect it, while many times, even as late as 1820 the circuit rider received littie pay worth naming. The circuit rider on the Bloomington circuit in 1820 received as a part of his quarterage home made leather socks, and jeans. The preachers sometimes wore whole suits of leather, because leather resisted the briers, as wool could not. ${ }^{11}$

In 1821-1822 Allen Wiley was serving the White Water circuit with James T. Wells as his associate. Weils was a very peculiar man, and although he was conscientious and extremely religious, yet because of his peculiarities he was more of a hindrance than a help. During this year Wiley says: "I then had a wife and seven children, and my entire receipts for house rent, fuel, table expenses and quarterage, amounted this year to seventy-six dollars. Then there were no estimates for house rent, and quarterage for children; so that if there were a married and a single preacher on the circuit the collections were divided into three parts, and the married man received two parts and the single man one; or if one preacher had ten children and the other none, they both shared equal when they were both married men."12

Between the years 1820 and 1824 a number of new circuits had been created within the limits of Indiana, and in the year 1824 there were seventeen circuits, wholly or partially within the state. In the Miami District of the Ohio Conference, over which John Strange was the presiding elder, there were Oxford, Greenville, Whitewater, Lawrenceburg, Madison and Connersville circuits; while in the Indiana District of the Missouri Conference, over which William Beau-

10 Autobiography of Rer. Joseph Tarkington, 75.

11 Ibid., S5.

12 Western Christian Advocate, June 26, 1846. 
champ presided there were eleven circuits, namely, Charlestown, Flatrock, Blue River, Bloomington, Honey Creek, Vincennes, Patoka, Mount Sterling, Corydon, Indianapolis and Eel River. ${ }^{13}$

In 1821 William Cravens was sent to Indianapolis to organize a circuit. A few Methodist families had settled on White river in the vicinity of Indianapolis, and the conference wisely saw the necessity of the early planting of religion in the center of the new state. Cravens was just the man for the new circuit, zealous, fearless and an indefatigable worker. Coming on horseback to his new circuit, he met with swollen streams and in attempting to ford Sugar creek, he was swept from his horse and thrown into the stream. A settler seeing the horse come out of the stream without a rider went to the bank to investigate; he saw a large, middle aged man crawling out of the water upon the limbs of a tree-top which had fallen into the stream. As he was climbing onto the tree the settler heard him soliloquizing, "Well, bless God, I would go to heaven if it were Sugar creek all the way." 14 Cravens was a Virginian and while a resident in that state had been fearless in his denunciation of slavery and drunkenness, and when he moved to Indiana he did not cease his denunciations of both evils. He seldom preached a sermon without "making all who made, sold, or drank ardent spirits feel uneasy." He found some residents in Indiana who had hired out their slaves in the slave

13 Ninutes, Vol. I, 367, 421, 425. There is some doubt about Oxford and Greenville circuits being in Indiana. In 1812, Allen Wiley says, Oxford circuit was part in Ohio and part in Indiana. Wiley includes these two circuits in the lists of Indiana circuits in his article of June 26, 1846, in the Western Christian Advocate for the year 1821-1822. Greenville circuit was probably partly in Indiana until 1827. Part of Oxford circuit was in Indiana until 1828. Western Christian Advocate, July 17, 1846. (Allen Wiley, Article No. XXVI.)

14 F. C. Holliday, "Life and Times of Allen Wiley," 45, 46. 
states, and were drawing their wages, while many more had sold their slaves and had purchased homes for themselves in Indiana with the price of their slaves. These he denounced as "hypocrites, and worse than the actual slave holder."

An early Steward's record of the old Connersville circuit, which was organized in 1822 , affords considerable insight into the method of paying the preacher, in the pioneer days. The record reads as follows:

To cash received from Lewis's class__________ $\$ .50$

To cash received from Curtis' class_______._- $\quad .50$

To cash received from Connersville class_-_-_ 2.50

To cash received from Abbott's class _-_._-_- 1.00

To cash received from Hardy's class --_-_-_- $\quad 871 / 2$

Bridle leather from Hardy's class_._._._._. $621 / 2$

Cash from Tullis's class__-_-_-_-_-_-_-_-_ 1.25

Shoe leather and corn from Tullis's_-_-__-_- 1.75

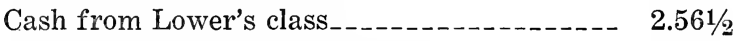

1 pair of shoe soles from Lower's_-_-_-_- $\quad .50$

Cash from Robert's class__-_-_-_-_-_-_-_-_- 4.65

Cash from Hardy's class_-_-_-_-_-_-_-_-_ $\quad .75$

$21 / 2$ yards of linsey from Hardy's class_.....- 1.121/2

Cash from E. Abbott's class _._._._._._._._. 1.32

Cash from Curtis's class_-_-_-_-_-_-_- $\quad .50$

7 yards of linen, from Curtis's

One small pair of shoes from Curtis's_-_-_-_- 1.00

$33 / 4$ yards of linen from Alley's class_______- 1.25

$21 / 2$ yards of linsey from Alley's class_.....-- 1.25

83/4 yards of linsey from Lewis's class___._._- 3.27

1 pair of socks from Lewis's class__-_-_-_-_- $\quad .433 / 4$

Cash from Grigg's class _..._._._._..... 2.121/2

$\$ 36.12 \frac{1}{2}$ 
By cash to A. Cummins, traveling expenses_ .50

By cash to J. Havens, traveling expenses_-- $\quad 1.50$

To A. Cummins, allowances________- 3.75

To J. Havens, allowances $30.371 / 2$

$\$ 36.121 / 2^{15}$

In 1824 the presiding elder of the Indiana District of the Missouri conference was William Beauchamp, one of the most eloquent preachers in the west. $\mathrm{He}$ was a native of Delaware, his father having been a Methodist preacher in that state, and also in western Virginia. In 1794 Beauchamp joined the Conference and was appointed to the Pittsburg circuit, and later served circuits in New York, Boston and Provincetown, Massachusetts. On his marriage in 1801 he located, and later moved to the western part of Virginia. Though he was no longer serving regular circuits, yet his interest in religion and the church did not wane, and in 1811 he published at Marietta, Ohio, "Essays on the Truth of the Christian Religion," which had a wide circulation and reading among other denominations as well as in the Methodist church. In 1816 he became the editor of the "Western Christian Monitor," a monthly religious paper, established at Chillicothe, Ohio, especially to combat Arian and Pelagian doctrines. In 1822 he resumed the active ministry and continued it until his death, which occurred on the 8th of October, 1824, in the fifty-third year of his age, in the State of Indiana. ${ }^{16}$

Beauchamp was styled the Demosthenes of the west. His voice was remarkably tender with a note of quite indescribable sweetness about it. In argument,

15 Western Christian Adrocate. November 21, 1860. Article by F. C. Holliday.

16 Methodist Magazine, Vol. VIII, pp. 17, 49, 86. A short sketch of the life of Beauchamp will also be found in Minutes, vol. I, 474. 
however, his voice became elevated and it then assumed a deep and hollow tone, which had a telling effect upon opponents, and on one occasion literally staggered an antagonist who, on attempting to leave the house during the sermon of Beauchamp, staggered, and catching a railing, sank into his seat, seemingly overwhelmed. ${ }^{17}$

Five typical circuit preachers during the twenties and thirties in Indiana were, Allen Wiley, Calvin Ruter, James Armstrong, James Havens and Joseph Tarkington. Allen Wiley commenced his career as an itinerant in 1816, his first circuit being the Lawrenceburg which he traveled with Russel Biglow as the senior preacher, and for a period of thirty-one years his name is a conspicuous one in the annals of Indiana Methodism, and in the writing of an account of early Methodism in Indiana perhaps his name will appear more frequently than that of any other.

James Havens was admitted on trial into the Ohio Conference in 1820. He entered the ministry under peculiarly discouraging circumstances, and in the face of them he achieved distinction and success in his chosen work. He had a very limited education, in fact when he entered the conference he could scarcely read. $\mathrm{He}$ had a large family, and was very poor in this world's goods, but by indefatigable work and by sheer force of character he became one of the conspicuous leaders in the church. He was a man of medium height, but was very strong and his courage and strength were often called into play in subduing the lawless and protecting those who desired to worship God in quietness. He gathered multitudes into the church and in spite of his late start he became an able defender of the truths of christianity and the possessor of considerable personal culture. ${ }^{18}$

17 F. C. Holliday, "Life and Times of Allen Wiley," 92, 93. is F. C. Holliday, "Indiana Methodism," 54. 
James Armstrong was a native of Ireland and was brought to this country by his parents when a child. He was converted and joined the church in Philadelphia where he was licensed to preach. In 1821 he came to Indiana and in the fall of that year he jcined the Illinois Conference. He was an excellent administrator and served many terms as a presiding elder, and was exceedingly successful in winning people for the church. He was supplied with a great fund of ready wit, which he often used as a keen weapon, to the confounding of self-conceited skeptics of which the frontier seemed to possess an oversupply. On one occasion he was preaching in the hall at New Harmony, Indiana, which was open to all denominations or to any one who had any message to give. It was the custom of a certain $\mathrm{Mr}$. Jennings, one of the residents of the community, to rise in the meetings and question the preachers. He accordingly rose in his place while James Armstrong was preaching and asked, "Mr. Armstrong, how do you know you have a soul?" Armstrong answered, "I feel it." "Did you ever smell, taste, see, or hear your soul," said the questioner. "No," said Armstrong. "Then you have four senses against you," replied the skeptic. Then Armstrong asked his questioner, "Mr. Jennings, did you ever have the toothache?" "Yes," said Jennings. "Did you ever smell, taste, see, or hear the toothache?" asked the preacher. "No," replied Jennings. "Then," said Armstrong, "you have four sesnses against you."19

Joseph Tarkington began his ministry under James Armstrong, who in 1824 was the presiding elder of the Indiana District of the Missouri Conference. His theological schooling consisted in traveling with the presiding elder for five weeks on the district, where he

19 A utobiography of Rev. Joseph Tarkington, 104. 
observed and learned what he could of the work to which he had given his life. One of the first sermons which Tarkington attempted to preach was from the text, "Prepare to Meet Thy God." He said, "I was badly scared but the wife of Rev. J. W. McReynolds shouted and helped me out; for I quit when she commenced." One of the first circuits traveled by Tarkington was the old Patoka circuit. "I got as pay for that year," he says, "nine dollars and a pair of trousers." 20

Calvin Ruter entered the Ohio Conference in 1818 and was immediately transferred to the Illinois country as one of the group of volunteers who were sent into the new country. He entered so heartily into his itinerant duties that his health soon gave way under the strain. Several times during his ministry he was forced to take a supernumerary relation, but with returning health he re-entered the active ministry and continued his work. He became the first secretary of the Indiana Conference at its organization in 1832, and his name appears conspicuously upon the records of the church in Indiana for many years.

Few of the men who planted Methodism in the State of Indiana were educated men in the sense in which we now consider that term. Their schooling was as a rule very limited, but somehow they became efficient interpreters of a larger life, and as a class, they developed a keenness of mind, and a readiness of wit that has rarely been equaled. They were men of few books, but they must have absorbed the few they possessed. They always carried some books with them on the circuit, in their saddle-bags, and like Wesley many of them read and pondered as they rode through the woods. The circuit-rider always carried a Bible

20 Ibid., 91-103. 
and hymn book, and a discipline, and usually a copy of Wesley's Sermons or Fletcher's Appeal. ${ }^{21}$

The General Conference of 1824 divided the Missouri and Ohio Conferences, and placed the States of Illinois and Indiana into a new Conference, which was called the Illinois. The time and place of the session of the Missouri Conference for 1824 had been fixed six months before the General Conference met, and as the time was short, it was decided that for the first year the two Conferences should hold their sessions at the same time and place. Therefore, in October of the year 1824, three bishops, McKendree, Roberts and Soule, were present at this joint session of the Conferences held at Looking Glass Prairie, Missouri. The following year, however, the two were permanently separated, and the new Illinois Conference met at Charlestown, Indiana, in August, 1825.22 The year started with an increase of six new circuits within the state, Rushville, Salem, Paoli, Boonville, Vermillion and Mt. Vernon.

This was still the days of big circuits. In 1825 Vincennes circuit included the following preaching places: In Knox county, Vincennes, Cane's, Thomas's, Snyder's, Terebaugh's, Nicholson's, Hawkins'; in Davis county, Bethel Meeting-house, Stuckey's; Thomas Havell's, Widow Stone's, T. Stafford's, Ballon's ; in Martin county, Hammond's, Clark's, Mount Pleasant, Love's, Maner's in Green county, and back again in Davis county to Bratton's, William's, Osmon's and Florer's. ${ }^{23}$ In 1828 the Rushville circuit included Rushville, county seat of Rush county, Greensburg, county seat of Decatur county, Shelbyville, the county seat of Shelby county, and went within a mile of Greenfield,

21 "Autobiography of Joseph Tarkington." Editerl by T. A. Goodwin, p. 8 .

22 F. C. Holliılay, "Indiana Methodism," 63.

23 Holliday, "Indiana Methodism," 65. For the preaching places on the Indianapolis circuit in 1825,69 . 
east along the National road as far as Blue river, and formerly it had gone as far north as Newcastle, county seat of Henry county. ${ }^{24}$ The Fall Creek circuit was organized in 1828, embracing the territory around Anderson, then called Andersontown. In the minutes of the Quarterly meeting for that circuit held in March, 1829 , the following preaching places were given: Pendelton, Andersontown, Montgomery's, Carey's, Waddell's, Goe's, Smith's, Rector's, Bank's, Fuller's, Black's, Reddick's, Garrett's, Jordon's, Sargent's Sibert's Kirkendall's. The sum collected for the quarter was $\$ 16.611 / 4$, and the amount paid Allen Wiley, the presiding elder, was $\$ 2.71$, while Charles Bonner, the circuit preacher, received, $\$ 13.551 / 4.0^{25}$

From these lists of preaching places we notice that the homes of the people are still, in the majority of cases, serving as preaching places. Even the Vincennes circuit eighteen years after its organization, had few meeting houses. To give an idea of how the new preachers were received on the early circuits, and how they made their preaching appointments, I will let Joseph Tarkington tell of his reception to the Patoka circuit, to which he was appointed in 1825, with James Garner as senior preacher: "The first place I came to on it (the circuit) was Archibald Campbell's, a mile from Petersburg. It was night and I called and asked to stay. Mrs. Campbell came to the door and said, 'No, we are all sick, with no one to put up your horse.' I told her I could put up my horse, and she said, 'Well, if you can wait on yourself and do without supper, you can stay.' And so I did. Mr. Campbell had a very high fever at the time, and turned to me, when I came in and set down my saddle-bags and said, 'You are traveling, sir?' I answered 'Yes.' " Mr. Camp-

24 Western Christian Adrocate, July 17, 1846; Beggs' "Early History of the West and Northwest," p. 70 .

25 From the Quarterly Conference records of the old Fall Creek circuit. 
bell then asked where he was from, and when Tarkington replied that he was from Charlestown, Mr. Campbell asked if he knew who their preachers were, and on Tarkington's telling the name of the presiding elder, and the senior preacher, the host asked, "Well, who is the other one? We had two last year." Thereupon Tarkington replied that the bishop had sent him. Campbell then said, "Why, what can you do?" "Not much," Tarkington replied. "Well," said Campbell, "wife, give him some cornbread and cabbage to start on." Tarkington said, "I started on it after a fiftymile ride that day." "The next day I went on giving out appointments for Mr. Garner, and that night got to O'Neal's, near the place of Major Robert O'Neal, who had sold out and was going to Sangamon county, Illinois. I preached there, and after the sermon, Major O'Neal said: 'I will be gone before Mr. Garner comes. Who of you will open your house for preaching?' All was silent for some time, and then Major Robb arose and said: 'Rather than have no preaching in the neighborhood, I will open my house. I have a large bar-room, and there are several sinners at my house. If you accept of what I have you are welcome.' So an appointment was given out for preaching at Major Robb's, in two weeks. The Major treated the preachers well all that year, and though he never made any profession of any religion yet all the female members of his family became religious." 26

The session of the Illinois conference in 1826 met at Bloomington, Indiana, and in that year the Indiana circuits contained a membership of nearly eleven thousand. The third session of the conference met at Mt. Carmel, Illinois, in September, 1827; the fourth session of the conference met in Madison, Indiana; the fifth session in Edwardsville, Illinois; the sixth session in Vincennes; and the last session of the old Illinois con-

26 Autobiography of Joseph Tarkington, 101-106. 
ference was held in Indianapolis, October 4, 1831. During these years the circuits were spreading out rapidly to the northward, following the population as it expanded in that direction. In 1829 the Logansport Mission was organized with Stephen R. Beggs as the missionary. In 1830 the Indianapolis District appears with James Armstrong as the first presiding elder, which embraced Indianapolis, Franklin, Fall Creek, White Lick, Greencastle, Rockville, Crawfordsville and Logansport. This year also Ft. Wayne Mission was organized. By 1831 it was found expedient to organize another district, farther north and the Crawfordsville district was accordingly added. The work in Indiana was now included in five districts, the Madison, Charlestown, Indianapolis, Crawfordsville and Wabash. The charges lying in the north part of the state in this year were Greencastle, Crawfordsville, Lafayette, Pine Creek, Rockville, Logansport, South Bend and Ft. Wayne.

The period from 1825 to 1832 is noticeable for the changes and readjustments made in the size and location of circuits. The Conference of 1827 divided the old Whitewater circuit, and the northern part was called Wayne, and Stephen R. Beggs and William Evans were the first circuit preachers. Beggs was the first Methodist preacher to attempt to hold a two-days' meeting in the Quaker stronghold of Richmond, and so successful was the meeting that it gave the cause of Methodism great impetus there, so that now Methodists far outnumber the Quakers. ${ }^{27}$ The next year Beggs was sent to the Crawfordsvilel circuit, and during that year organized a class at Lafayette, conststing of twenty members. At this time the Crawfordsville circuit reached practically across the state. The main preaching places on this circuit were Crawfordsville,

27 Beggs "Early History of the West and Northwest" (Cincinnati, 1868). 75-76. 
Fort Wayne, Logansport, Delphi, Lafayette, Attica, Portland, Covington and back to Crawfordsvilie once more. ${ }^{28}$ The subordinate and intermediate preaching places, however, outnumbered the principal ones, so that the preacher had to preach from five to seven times a week. The Portland here referred to was an old town located about half way between Attica and Covington, and in the early days was an important trading center. The appointments on the Crawiordsville circuit were all on or near the Wabash river, which greatly facilitated the traveling of the circuit. ${ }^{29}$

In the fall of 1829 Stephen R. Beggs was sent to organize a new circuit, which was known as the Logan's Port Mission, and included as the three main preaching places, Logansport, Delphi and Lafayette, with a number of intermediate places. These newer circuits were four weeks' circuits, that is, it took the preacher Iour weeks to make the complete round of the circuit, and these seem to have been the largest circuits at this period, though from ten to twenty years previous, six and even eight weeks' circuits were not uncommon. The usual size of the circuit at this time was two or three weeks.

It was during the twenties and early thirties that the name "Station" made its first appearance among the appointments in Indiana. It was in the list of appointments for 1825 that Madison station and Salem station appeared. ${ }^{30}$ A few years later Lawrenceburg and Indianapolis became stations, and by 1831 New Albany and Bloomington had been added to the number. Many of the old circuit preachers greatly opposed the doing away of the old circuit system, many of them maintaining that it was this system, more than anything else, that had been responsible for the great

28 Ibid., 208.

29 Ibid., 81.

30 Minutes for 1825. 
progress of Methodism on the frontier. ${ }^{31}$ But as the towns grew in population and wealth the demand of the membership in these larger places became more and more insistent for stationed preachers, and as time went on the number of stations greatly increased.

The founders of Methodism have been criticised for their lack of foresight in taking little or no thought for the accumulation of property for the church. ${ }^{32}$ In the early days excellent sites for church buildings might have been had for the asking in all the towns, yet most of the early meeting houses of the Methodist church were built in country districts, and they were built with little or no reference to the permanent centers of population. As a consequence, when towns began to develop many churches were found to be wrongly located, and as the country became older and the demand for Sabbath preaching compelled the discontinuance of week-day appointments, many of the older church buildings ceased to be occupied. They were built too close together for Sabbath appointments and yet it was always difficult, as at present, to unite the small country churches into a common center, for the erection of a larger church. Other denominations were erecting large church buildings, years before the Methodists were able to do so, and it is not an uncommon thing to find Methodist conferences sitting in Presbyterian and Baptist churches, although numerically the Methodists were the largest denominatiton in the state. The Methodists, however, began to make improvements in their church buildings, during the latter years of the old Illinois conference, and the old log churches began to give place to the plain brick or frame church, without steeples or bells.

As the population of Indiana crept northward, schemes for internal improvements began to be agi-

31 Rev. W. C. Smith, "Indiana Miscellany."

32 Holliday, "Indiana Methodism," 155. 
tated, especially in the matter of road building. The earliest roads were state roads, and then came the National road. These improvements had their reaction on church development. The early circuits were so large and the settlements so scattered and remote from each other, that the improvements in the roads not only greatly benefited the preacher, but also the people who had to travel long distances to hear him. It is an interesting fact, although the reason for it is not definitely known, that preaching appointments were for 12 o'clock, on all days except the Sabbath. Perhaps the reason for this was that everybody could tell on a clear day when it was noon by the sun, for there were few clocks and fewer watches among the people.

By 1832 the Methodist membership in Indiana had grown to nearly 20,000, and during the twenties there had been a number of remarkable revivals in various places over the State. Probably the greatest numbers, which the preachers succeeded in winning to the church, were won as the result of camp-meetings, held during the spring and summer months. Almost every circuit had somewhere within its bounds a camp-meeting ground, and the camp-meeting occasion was the great occasion looked forward to by all on the circuit. It was about the only vacation enjoyed by the people of the frontier, and served a social as well as a religious purpose. The idea, often expressed, that early Methodist converts were won in meetings, held in close rooms, is absolutely untrue, for the greatest religious revivals were conducted out in the open air, and every convert, who fell prostrate on the straw, had his lungs filled with pure oxygen. In these campmeetings very often strange and seemingly supernatural things happened. In the year 1831 a camp-meeting was held on the Wayne circuit, and during the meeting many were converted. Some of the converts would begin to laugh, and would continue doing so for 
hours. After the laughing commenced it seemed practically impossible to stop it. ${ }^{33}$ Opinion was so divided on the matter that the minister preached and advised concerning it, from the pulpit, suggesting that those who laughed "should not invite the exercise," and those who scoffed "should not doubt the sincerity of their brethren, for they could not help seeing that the thing was involuntary when once commenced." One man was almost thrown into the "jerks" of former days by resisting the laughing symptoms. It was told that a woman in Kentucky laughed all day and all night after she was converted.

Long protracted meetings held during the winter months, had not yet come into vogue, though the two day meetings were common. Such a meeting was held, as has been noted above, on the Wayne circuit in 1828, the preacher, Stephen R. Beggs, being assisted by the local preachers on the circuit. The meeting was held in the school house at Richmond, and created considerable excitement among the Quaker population, some of whom had never seen or heard Methodist preaching. There were six or seven converts, and some of them desired baptism; some chose pouring, others sprinkling and one asked to be immersed. Accordingly the congregation, with many curious onlookers, including a number of Quakers, went to the banks of Whitewater to see the sight. One man was so curious that he waded out into the water so that he might get a better view of the performance, and so intent was he that he macie a misstep and with his little boy, whom he had carried out with him, he fell backwards into the stream. At this some of the onlookers shouted with laughter. ${ }^{34}$ The year on the Wayne circuit was closed with "a powerful union camp meeting" and such famous camp-

32 Western Christian Adrocate, October 20, 1846. Article by Allen Wiley.

34 Beggs, "Early History of the West and Northwest," 75-79. 
meeting preachers as John Strange and James B. Finley, of Ohio, were present.

Of all the camp-meeting preachers in Indiana during these years, none were so popular as John Strange. One who often heard him preach states that "There never has been a man in Indiana who could move and stir an audience from center to circumference equal to him." 35 On one occasion when preaching on a Sabbath morning at a camp-meeting in Wayne county to a vast crowd, in the midst of his sermon he took one of his flights of eloquence, which raised a great shout from the congregation and lifted the people from their seats. Hearing the shouting the crowd on the outside of the meeting place rushed in and as they came pouring down the center aisle, Strange, raising on his toes and throwing himself a little back, with his right arm extended, pointing with his finger directly toward the young men coming in, screamed in a voice that made the forest ring, "Here they come now! My Lord! Shoot them as they come." And one of the young men who was among those coming in states that he sank down in the nearest seat, unable to move until the sermon was finished.

The eloquence of these pioneer preachers was not the kind learned in the schools from the study of books, and there is no better way to account for it than to let John Strange, this prince of circuit-riders and western orators, tell of the school in which he learned it. His Alma Mater, said he, was "Brush College, more ancient though less pretentious than Yale or Harvard or Princeton. Here I graduated and I love her memory still. Her academic groves are the boundless forests and prairies of these western wilds; her Pierian springs are the gushing fountains from rocks and mountain fastnesses; her Arcadian groves and Orphic

35 Western Christian Adrocate, June 23, 185. Article by W. C. Smith on "John Strange at Camp-Meetings." 


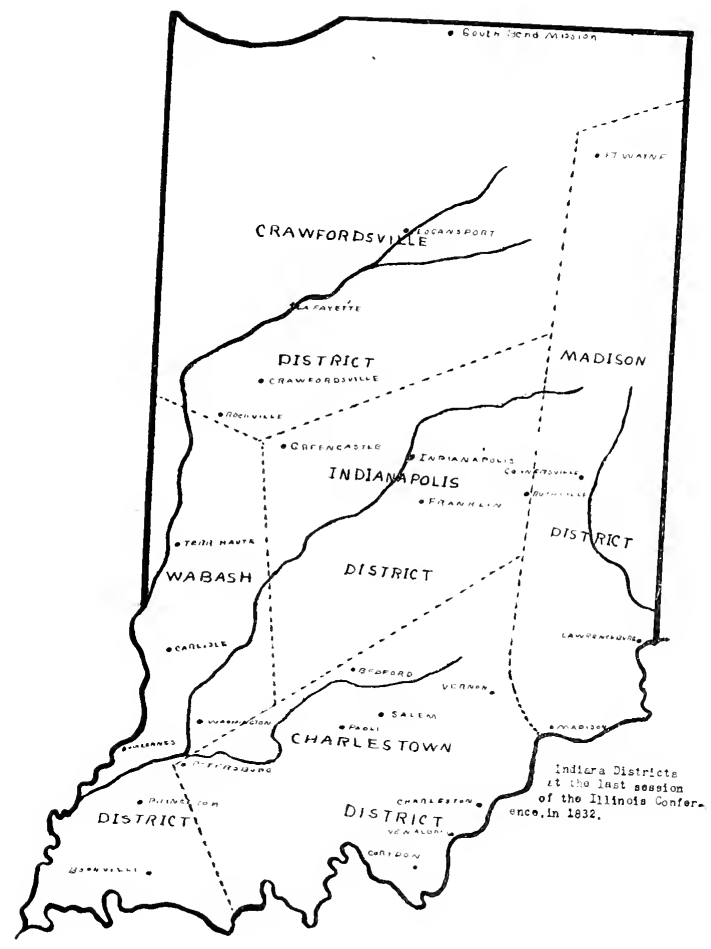



songs are the wild woods, and the birds of every color and every song, relieved now and then with the bass hootings of the night owl and the weird treble of the whip-poor-will; her curriculum is the philosophy of nature and the mysteries of redemption; her library is the word of God, the discipline and the hymn book, supplemented with trees and brooks, and stones, all of which are full of wisdom and sermons and speeches; and her parchments of literary honors are the horse and saddle-bags." 36

In the sixteen years since Indiana had become a State many influences had been at work developing the new commonwealth from a pioneer district to a well organized and prosperous condition, and by 1832 it seemed expedient that Indiana should be set apart into a separate conference. There were nearly 20,000 Methodists within the State, and accordingly the General Conference of 1832 decided that it was for the best interest of both Indiana and Illinois Methodism to form a separate conference to include all the stations and circuits within the State of Indiana, and a strip of territory in the southern part of Michigan. With the formation of the Indiana conference, Indiana Methodism begins a new and larger chapter in its history. In a sense the pioneer days are passed and the church is firmly established in the new commonwealth.

36 J. C. Smith, "Early Methodism in Indiana," 3S-39. 


\section{CHAPTER III.}

THE OLD INDIANA CONFERENCE, 1832-1844.

If any single period in the history of Indiana Methodism stands out more conspicuously than any other. it is the period from 1832 to 1844, the years of the life of the old Indiana Conference. These are notable years because of the outstanding leadership; when such men as Allen Wiley, James Havens, Matthew Simpson and Edward R. Ames were in their prime. These were years also of conspicuous progress in the church throughout the State. When the Indiana Conference met for its first session it had a membership of thirtynine preachers, five presiding elders' districts, and the church membership in the state numbered 19,853 ; in 1844 , the year marking the close of the period, there were 206 preachers, sixteen districts and 67,118 members. For many, however, these years in the history of Indiana Methodism are rendered the more interesting because they mark the inception and the founding of Indiana Asbury University, now DePauw University. The old Indiana Conference and the founding of this next to the oldest living Methodist College in the old Northwest, are inseparably connected, and the history of both during these early years belong together.

The first session of the Indiana Conference met in New Albany on October 17, 1832, Bishop Joshua Soule presiding. Eighteen members were present at the first roll call, and responded to their names in the following order: Allen Wiley, Joseph Tarkington, John Kern, Daniel Anderson, Samuel C. Cooper, George Locke, James Havens, Asa Beck, Charles Bonner, John T. Johnson, William Shanks, C. W. Ruter, James Armstrong, William H. Smith, Enoch G. Wood, James Scott,

1 See Minutes for 1832 . 
Richard S. Robinson and Boyd Phelps. C. W. Ruter was elected secretary of the Conference, which position he held continuously until 1838, when ill health compelled him to give it up. The Conference convened on a Wednesday and adjourned on the following Monday morning. Among the items of important business transacted was the adoption of by-laws for the governing of the Conference, and these by-laws, with slight change, were continued in force throughout the twelve years of the life of the old Indiana Conference. ${ }^{1}$

A collection was taken up for John Strange, whose health had recently given way, and like most Methodist preachers, he had little of this world's goods to tide him over such a crisis. This collection helped to purchase a house and lot in Indianapolis for him, where he died a few months later, December 2, 1832. It is doubtful if there has ever been a Methodist preacher in Indiana more universally loved than John Strange, and for years after his death his name is frequently found on the lips of those who admired and loved him, both among the ministry and laymen.

An interesting case which came before the Conference in 1832, was that of Alfred W. Arrington, who was reported by his presiding elder to have withdrawn from the church, "having become skeptical in his mind," but that since his withdrawal he had become thoroughly convinced of the truth of Christianity, and deeply deplored his fall, and now begged to be restored to his former standing in the church. A motion was made that he be restored, but it was lost; the next day the motion was reconsidered and he was restored to the church. Arrington was a young preacher of great promise, and was reputed to have been one of the most eloquent of the young preachers in the State, but as one of the old preachers observed, his head had become dizzy through flattery, and he soon fell again, and finally he left the ministry and went to Arkansas where he became a successful lawyer.

One of the things which continually strikes a read- 
er's notice, as he goes through the minutes for these years, is the large number of men who are refused admittance to the Conference. The journal records the names of those admitted, and then states that so-and-so were not admitted, giving no reason, however, for the action, though the statement generally follows that the presiding elders have leave to employ them if they think it necessary. One of the chief reasons for the refusal of the Conference to accept preachers was because they were married. It was a rule of the church, "as inexorable as death," that no man, no matter what his age or circumstances, should marry until he had traveled four years. ${ }^{2}$ This rule was doubtless a wise one when it was adopted, but when the extreme frontier conditions had passed, as was true in Indiana by 1832 , the enforcement of the rule led to both injustice to candidates for the ministry and a great loss to the church itself.

Another rule of the church which made marriage for the young itinerant very difficult, and romantic love affairs next to impossible, was the rule which required the unmarried minister to consult his brethren on the subject, before he was to mention love or marriage to the young lady of his choice. "The rule did not say what brethren were to be consulted, but the presiding elder always assumed that they were ex-officio entitled to be consulted." Strange as it may seem to us in these days every circuit seemed to have somewhere in its bounds a "pious young sister, every way qualified to become a first-class wife for a preacher;" . . . and willing to endure all the hardships of the itinerancy if they might providentially be called to it." To make the situation more embarrassing to the young preacher, he had no home on the circuit except where his saddle-bags happened to be, and frequently he was

2 Autobiography of Joseph Tarkington, 28.

Western Christian Adrocate, July 14, 1858. 
compelled to stay at the home of one of these self-sacrificing young sisters, and often perhaps her home was the only stopping place for that appointment, and thus he was brought face to face with her once every four weeks. "Common politeness required him to be courteous to all, and the instincts of a gentleman would lead him to be respectful to the grown daughter, who never failed to be in her best attire and on her best behavior during his stay, and often at the expense to him of many an hour that he ought to have spent with Watson's Institutes or Wesley's Sermons, whether he preferred it or not."

In one such home in the early thirties was an accomplished daughter who had favorably impressed three young preachers, and each determined to take the first opportunity of consulting the presiding elder on the subject of matrimony. Accordingly all three went to a camp-meeting, which was held near the center of the district, in which they all had circuits. Neither knew why the others were there. One obtained an early interview. He began by telling the elder that his four years of celibacy was about up, and that he had been making the matter of marriage a subject of prayer, and the Lord had indicated to him that he ought to marry. The elder inquired who was the happy girl, and received the reply, "Cora ____." “A splendid girl," said the elder, "and will make any man a good wife." And soon the young preacher was on his faithful horse speeding to Cora's home to begin his courtship.

Soon after this young preacher number two drew the presiding elder to one side and made practically the same speech and received the same reply and the same indorsement of Cora. Later in the same day preacher number three had a hearing, making a similar speech, and winding up as the others had done with Cora. To him, however, the presiding elder replied: "Now see

3 Tarkington Autobiography, 29-32. 
here, my young brother, there must be some mistake somewhere. Cora — is a splendid girl: but you are the third man who has today said the Lord had indicated her for a wife. Somebody must have misunderstood the Lord."

Two other items of business transacted by the conference of 1832 are of importance. On the first day of the conference a committee was appointed, consisting of Allen Wiley, C. W. Ruter and James Armstrong, to consider the propriety of establishing a literary institution under the patronage of the Conference. The committee presented their report, recommending that the conference establish such an institution, and that the presiding elders collect all the information possible as to possible sites and means of raising money. The journal also records two bequests which had been made to the Methodist Episcopal church in Indiana, one by Col. James Paxton and the other by Isaac_Swearingin, and Allen Wiley and James Armstrong were appointed agents to receive the bequests for the conference. This was the beginning of the Preacher's Aid Society, of the Indiana Conference, though the society was not formally organized until 1834.

When the appointments were read at the close of the first session of the Indiana Conference, the State was divided into five districts, Madison, presided over by James Havens; Charlestown district, William Shanks, presiding elder; Indianapolis district had for its elder, Allen Wiley; James L. Thompson was appointed to the Vincennes district and James Armstrong was given a missionary district. There were sixty preachers appointed to some forty charges. The missionary district included Upper Wabash mission, St. Joseph and South Bend mission, Kalamazoo mission, Fort Wayne mission and LaPorte mission. ${ }^{4}$

The second session of the Indiana conference met at Madison, in October, 1833, Bishop Soule again pre-

4 Minutes of Conferences, Vol. II (1829-1839), 173-175. 
siding. An increase of membership was reported of 3,582, giving a total membership for the state of 23,617 . Resolutions were adopted favoring the establishment of a periodical at Cincinnati, and the next year the Western Christian Advocate began its honorable career at Cincinnati, with Charles Eliott as the first editor. The missionary district was this year called the Northwestern district, over which James Armstrong again presided. 5 The third session of the conference met at Centerville, on October 22, 1834, Bishop Roberts presiding. This year two new districts were added, the Crawfordsville and the LaPorte districts, making seven in all, and an increase of 1,684 members reported. This year the death of three of the veteran preachers was reported, George Locke, James Armstrong and Nehemiah Griffith, all of whom had done valiant service for the church. ${ }^{6}$

In 1835 the conference met at Lafayette, Bishop Roberts again presiding. The increase in membership for the year was only 263 , but as the whole church went behind near 2,000 this year the gain in Indiana was creditable. At this conference, General conference delegates were elected in the following order, C. W. Ruter, Allen Wiley, James Havens and J. L. Thompson, with Aaron Wood and William Shanks as reserve delegates. $^{\top}$ The next year, 1836, the conference met in Indianapolis, and Allen Wiley, until the arrival of Bishop Roberts, was elected president, pro tempore. This year there was an increase of 2,616, and a class of twenty-four was admitted on trial into the conference. A new district was added which was named the Centerville, making eight districts in all, the new district being located in the northeastern section of the State. Among the leading questions discussed at this conference was the location, organization and endow-

5 See Minutes for 1833 .

6 Minutes for 1834 .

7 Minutes for 1835 .

8 Minutes for 1836. Western Christian Adrocate, May 19, 1858. 
ment of the new university, which the Conference had determined to establish. ${ }^{8}$

No sooner had Indiana been set apart as a separate conference, than there began to be an agitation for the establishment of an institution of learning under the control of the Methodist Episcopal church. On the first day of the first session of the Indiana Conference, which met in New Albany, in October, 1832, a committee consisting of Allen Wiley, C. W. Ruter and James Armstrong was appointed to consider and report on the advisability of establishing such an institution. In their report they state, "We therefore think that seminaries and colleges under good literary and moral regulations are of incalculable benefit to our country, and that a good conference seminary would be of great and growing utility to our people." They further state "When we examine the state of the literary institutions of our country, we find a majority of them are in the hands of other denominations (whether rightfully or otherwise, we do not take it upon ourselves to determine) - whose doctrine in many respects we consider incompatible with the doctrines of revelation, so that our people are unwilling (and we think properly so) to send their sons to those institutions. Therefore we think it very desirable to have an institution under our own control from which we can exclude all doctrines which we deem dangerous; though at the same time we do not wish to make it so sectarian as to exclude or in the smallest degree repel the sons of our fellow citizens from the same."

The committee closed their report by recommending that the presiding elders of the various districts be "required to collect all the information in their power in reference to an eligible site, and the means to build, and present the same to the next conference."9

At the session of the conference in 1833, just before the close of the session, a committee was again appointed to "make inquiries relative to the establish-

9 Minutes for 1832. 
ment of a conference seminary," and on this committee were appointed A. Wiley, James Armstrong, James Havens, James L. Thompson and William Shanks. ${ }^{10}$

Although it was felt by many members of the conference that it was desirable to have a college in the State under the control of the Methodist church, yet it was thought if the Methodist church could receive an equitable share of privileges in the State University at Bloomington, that it would be better, at least for several years, for the church to actively support that institution, rather than found one of its own. ${ }^{11}$ Accordingly it was resolved, at the session of the Conference in 1834 to petition the State Legislature on the subject, and a form of a memorial was prepared by a committee of the conference. In the memorial it is stated, "We would impress it upon your honorable body that literature belongs to no one denomination of persons, and that no one exclusively, should be allowed to possess the keys that unlock her treasures. We apprehend that the funds of our State College were designed by their munificent donors to patronize science and advocate the cause of general literature and not of religious sects, and should it be divested from its original design (directly or indirectly) the donors are despoiled of a rich inheritance, and the legacy itself betrayed to a very questionable purpose. . . . We look in its charter (State College) and read that the places of president, professors and tutors are open, soliciting capacity to occupy them without regard to religious professions or doctrines. We then turn our eyes on the faculty from the organization of the Institution up to this hour and we see one common hue, one common religion characterize every member, as if capacity and fitness were combined to one church and one set of religious opinions." The memorial did not ask that

10 Ibid., 1833.

11 Article by F. C. Holliday on "Indiana Asbury University," Western Christian Advocate, February 17, 1858. 
the State College be put either in whole or in part under the control of the Methodist Church but they simply asked that the trustees of the college be elected for a deiinite term of years and that vacancies, as they occurred, should be filled by the Legislature and not by the remaining members of the board of trustees, as had been the custom heretofore. ${ }^{12}$

This memorial was signed by the members of the Conference, and six other similar memorials were presented to the state Legislature numerously signed, all of which were referred to the committee on education, but for some reason the committee never took any action in reference to them. ${ }^{13}$

The three oldest institutions of higher learning, founded in Indiana, with the exception of the old University of Vincennes, were Hanover and Franklin Colleges, and Indiana University. The University of Vincennes had been founded in 1806 and the national government had endowed it with a township of land, but its life was never vigorous, and it soon died and its endowment was taken for the present State University. The State University began its career in 1820 as a State Seminary, and it received in 1822 the endowment belonging to the Vincennes University. In 1828 it became Indiana College, and in 1838 Indiana College became Indiana University. The Baptists in 1834 began an agitation for a college under their control, and the next year, 1835, Franklin College was founded. The Presbyterians of Salem Presbytery, as early as 1825 were talking of founding a school, and in 1826 the Presbytery arranged with a certain John Finley Crow, who had been conducting a boarding school at South Hanover to enlarge his school into a classical school, and this was opened in $1827 . .^{14}$

For a number of years previous to the founding of

12 Minutes for 1834 .

13 House Journal, 1834, 82, 148, 155, 228, 236, 293, 368.

14 Esarey, History of Indiana, 291-293. 
Indiana Asbury University the Methodists had complained that the State College was under the control of the Presbyterian church. This was not alone true of the State College in Indiana but of Miami University at Oxford, Ohio, and the same accusation was also lodged against the State University of Kentucky. The Methodists considered the Presbyterians as extremely arrogant, assuming themselves to be the "only competent educators of the people," and as a result of the Presbyterian control of the State colleges in the West, but few young men from Calvinistic families were enrolled as students in the State Institutions. ${ }^{15}$ The Methodists had four chief complaints against the Indiana State College: (1) The Institution was regarded as belonging to the Presbyterian Church, and was listed among Presbyterian colleges. (2) The religious beliefs of Methodist students were not respected. (3) Efforts were made to convince the public that none but Presbyterians were competent to teach in higher institutions of learning; and (4) Under the existing system no Methodist could be represented on the board of trustees, although the Methodists were the most numerous religious sect in the State. ${ }^{16}$

One writer in the Western Christian Advocate, in 1835, signing himself "Indiana Itinerant," urges the establishment of a Methodist Seminary, as Hanover had already been started under Presbyterian auspices, and the State College was alleged to be under Presbyterian influence. ${ }^{17}$ Another article later in the same year pleads for the starting of a Methodist College in Indiana. This writer says that there are many Methodist parents who would prefer to have their children educated under Methodist influence, but are compelled to send them to Bloomington or Hanover both of which are under Presbyterian influence. He, however, wants

15 Holliday, "Indiana Methodism," 317-318.

16 F. C. Holliday, "Life and Times of Allen Wiley," 71-72.

17 Western Christian Adrocate, January 9, 1835.

1s Ibid., June 5. 1835. 
it distinctly understood that he does not favor a Theological Seminary. ${ }^{18}$ At this period the opposition to Theological Seminaries among Methodists was strong, even the editor of the Western Christian Advocate opposing their establishment in an editorial in which he points out that they are still in the experimental stage, that they would be dangerous to unanimity of opinion, and he also argues that literary institutions are enough, and that the tendency of Theological Seminaries would be to localize the itineracy. ${ }^{19}$ The first committee on education appointed by the Indiana Conference in 1832 , embodied in their report this statement, in regard to Theological Seminaries: "We are aware that when a Conference Seminary is named some of our preachers and many of our people suppose we are about to establish a manufactory in which preachers are to be made. But nothing is farther from our views, for we are fully of Mr. Berneges' opinion, who, when comparing ministers to pens, observes that although the Seminaries have been trying to make pens for hundreds of years, they will not write until God nibs them." 20

Failing in their efforts to secure a reform in the manner of controlling the State University, the conference turned their thoughts earnestly toward the establishment of a literary institution. Accordingly at the session of the Conference in 1835 which met at Lafayette a plan was agreed upon for the founding of a university. The committee on education reported an elaborate plan for raising money, creating a capital stock of an indefinite number of shares of $\$ 100$ each, any person holding one share of stock having the privilege of sending one student for six years to the university. The sum of $\$ 10,000$ was to endow a professorship, and the preachers and especially the presiding elders were to act as agents to get the plan started. Also provision was made for finding a suitable location

19 Ibid., January 9, 1835.

20 Minutes of Indiana Conference, 1832. 
for the university, the plan being to start a competition between two or more towns in bidding for the Institution. ${ }^{21}$ When the conference of 1836 convened representatives from several competing towns were present, Rockville, Putnamville, Greencastle, Lafayette, Madison and Indianapolis being the principal competitors. Rockville presented a subscription of $\$ 20,000$, Putnamvile about the same; Indianapolis and Madison, $\$ 10,-$ 000 ; Greencastle, $\$ 25,000 .{ }^{22}$ Calvin Fletcher, representing Indianapolis, did not labor hard for the Institution, saying that it was not good for boys to be away from home in as large a place as Indianapolis would be some day. General Howard represented Rockville, and in his speech admitted that there were some chills and fever at Rockville, whereupon $\mathrm{Mr}$. Fletcher admitted that some even died at Indianapolis, but Dr. Cowgill, representing Greencastle, said, "People never die at Greencastle, although for convenience they have a cemetery there." 23 Two ballots were all that was needed to determine that Greencastle should be the seat of the Indiana Asbury University, the name of the University having been decided by the Conference at their session in 1835 .

Greencastle at that time contained a population of about five hundred, the town having been laid out about ten years previous. It was therefore very new and very rough in appearance. The streets were without grading or sidewalks, except about the public square, and mud was a very abundant article for at least six months in the year. It was exceedingly fortunate for Greencastle that it secured the location of the college, for had it failed, the county seat would probably have been moved to Putnamville, and the influence given to

21 Minutes for 1835.

22 Western Christian Adrocate, February 17, 1858. Article on Indiana Asbury Iniversity, by F. C. Holliday. Dr. Geo. L. Curtin, in his semi-centennial address delivered June 21, 1Sst, gives somewhat different figures (Historical Addresses, 12).

23 Autobiography of Joseph Tarkington, pp. 131-132. 
the town by the University made it a point on the Indianapolis and Terre Haute Railroad and later gained for it also the New Albany and Michigan City Railroad.

The Conference then appointed a committee to draft a charter to be submitted to the Legislature at its next session, which was done, and the charter was passed substantially as drawn up by the committee. The following original board of trustees was then elected: Robert R. Roberts, John Cowgill, A. C. Stevenson, W. H. Thornburg, William Talbott, Rees Hardesty, Joseph Crow, John W. Osborn, Thomas Robinson, Hiram E. Talbott, James Montgomery, Daniel Sigler, Isaac Matkins, T. W. Fletcher, Gamaliel Taylor, Martin M. Ray, Isaac C. Elston, S. S. Leanard, W. W. Hitt, James A. Wright, T. A. Howard and Jacob Hass.

The first meeting of the board of trustees was held on the first Monday of March, 1837, at which it was decided to open a preparatory department as soon as a suitable teacher could be secured. Later Rev. Cyrus Nutt, a graduate of Alleghany College, was elected principal of the preparatory department at a salary of $\$ 400.00$ In due time the new principal arrived, and on the 5th of June, 1837, the school was opened in a room in the old town seminary building. Five pupils, bareicoted and without coats, appeared-o. Badger, O. H. P. Ash, William Stevenson, Osborn and S. Taylor, all of whom resided in Greencastle except Badger. ${ }^{2 *}$

On the 20th of June was the day appointed for the laying of the corner-stone of the college building. The little town was full of people, who had come from far and near, to witness the impressive ceremonies. At 9 a. m. a sermon was preached in the Methodist Church by Rev. Hooper Crews of Illinois. At 11 o'clock a procession was formed and they proceeded to the site of the University where a speech was made over the corner-stone by Calvin Fletcher, Esq., of Indianapolis.

24 Western Christian Advocate, February 17, 1858. 
This speech was heard by few, for it was delivered in a low voice. The procession then proceeded to a grove on the southwest border of the town where seats and platform had been erected for the occasion. On the platform were Rev. Ailen Wiley, James Havens, C. W. Ruter, and E. R. Ames, and a few other of the leading ministers of the conference. Prayer was offered by Rev. E. R. Ames, after which Rev. H. B. Bascom, reputed to be one of the greatest orators of the west, gave an address, which lasted two hours. The day was very chilly, and Dr. Bascom asked to speak with his hat on. During an interlude some rain and a little snow fell, and the speaker sat down a few minutes and while he was seated a Hoosier who had provided himself with a roll of ginger bread, stepped up behind the speaker's stand and pulling Dr. Bascom by the coat, broke off a piece of his ginger loaf and offered it to him, saying, "Mister, as you have been speaking hard, you must be hungry, here take a piece." Dr. Bascom thanked him kindly, but refused the refreshment, saying he had no occasion. ${ }^{25}$

The college proper was organized in September, 1837, and the Trustees elected Rev. Cyrus Nutt, Professor of Languages, and Acting President. In the spring of 1838 Rev. J. W. Weakley was appointed Preceptor of the Preparatory department. Rev. Matthew Simpson was elected President in 1839, and he arrived and took charge in May of that year. The first catalogue was published at the close of that term and the number of students recorded there is 140 . In the fall of 1840 the first commencement was held and President Simpson was inaugurated.2" The charge to the President was delivered by Governor Wallace, and the President delivered an inaugural address. The new

25 Testern Christian Adrocate. February 17. 1sas: Holliday. "Intliana Methodism." 320.

2f Crooks "Life of Simpson." 
building was completed and the college was safely launched upon its long and useful career. The first graduates were John Wheeler of Bellefontaine, Ohio; T. A. Goodwin of Brookville, Indiana, and James Maddox of Crawfordsville. In 1841 W. C. Larrabee was elected to the chair of Mathematics and Natural Science, and there are no two names in the history of Education in Indiana more important than Cyrus Nutt and W. C. Larrabee.

Cyrus Nutt remained a Professor in Indiana Asbury University until 1843 when he resigned and took an appointment in the Indiana conference and was stationed at Bloomington. In the fall of 1848 he returned to the University but the next year he was elected to the presidency of Fort Wayne Female College, where he remained but one year, going from that institution to the presidency of Whitewater College at Centerville. In this position he remained for a number of years when he again entered the ministry, serving as Presiding Elder of the Richmond district. Again in 1857 he returned to Indiana Asbury University, this time serving as Professor of Mathematics; he was elected also Vice-President and for nearly two years he was the acting president.27 In 1860 he was elected President of the Indiana State University and was inaugurated on June 7,1861 , the great war Governor, Oliver P. Morton, making the address of investiture. He served as President of the State University for fifteen years, resigning in $1875 . .^{28}$ It is extremely interesting that Cyrus Nutt, the first member of the faculty of Indiana Asbury University and a Methodist preacher, should serve as President of the State University during the years of the Civil War.

W. C. Larrabee was a native of Maine, and a gradu-

27 Hollid:y, Indiana Methodism, 281-2א5.

2S T. A. Wylie, Indiana University. Its History from 1820 to $1890,71-81$. 
ate of Bowdoin College in the class of 1828, and when Wesleyan University in Middletown, Conn., was opened he was appointed tutor and was the first actual teacher in that honorable institution. In $1840 \mathrm{Dr}$. Larrabee was a delegate to the General Conference, which met at Baltimore, and there he met Dr. Simpson, then president of Indiana Asbury University, and as a result of this acquaintance he was elected to the Chair of Mathematics and Natural Science in the new University. Dr. Larrabee remained at Indiana Asbury University until 1852 , when he was elected superintendent of public instruction, and was the first the state ever had, and while in that office he laid the foundation for Indiana's present school system. ${ }^{29}$

The year 1836 had been one of great prosperity in Indiana, as far as the Church was concerned. There was an increase of 2,616 members during the year, and the circuits reported great increase in the interest of the people in religious matters. The preacher on the Vevay circuit writes: "The Lord of the harvest hath begun to revive His work on Vevay circuit. The last two rounds on the circuit I have taken into the Church thirty-four members and my colleague has taken in several, and we have had a good many hopeful conversions. The membership are waking up from their long sleep and are trimming their lamps." ${ }^{30}$ The preacher on the Bedford circuit reports 129 received into the Church from that circuit. ${ }^{31}$ Richard Hargrave reported from Fort Wayne, "The cause is marching forward through much opposition in this far Northwest," 32 while the minister from the Noblesville circuit writes that when he came to the circuit in October, 1835, there were twelve preaching places and not a meeting house on the circuit, but that during the year

29) Holliday, 285-289.

30 Western Christian Advocate, February 12, 1836.

31 Ibid., October 21, 1836.

32 Ibid., July 22, 1836. 
money had been raised for the building of a meeting house at Noblesville, which was to cost $\$ 700$, and that there had been an increase of 103 members on the circuit. $^{33}$ During this year Elkhart circuit was organized with the following preaching places : Elkhart, Conley's, Warner's, Shelby's, Goshen, Gornell's, Elkhart Prairie, Woods', Hawpatch, Burton's, Little Elkhart, Shady Creek, Cross' and White Plains. ${ }^{34}$ Successful campmeetings were numerous during the year, on many of the circuits. On the Danville circuit 113 joined the Church as the result of a camp-meeting and another successiul camp-meeting added 84 to the Church on the Paris circuit. $^{35}$ William M. Dailey, writing from the Bloomington station in the midst of a revival meeting, says, "A considerable number have been added to the Church, but the crowning feature of this meeting is the number of clear and powerful conversions. *** The Lord is at work, sinners are shaken, the trembling throne of infidelity is falling, saints are on the wing and children are born to God. Hallelujah, Amen!" ${ }_{36}$ At a camp-meeting held near Indianapolis during the early fall of this year, a desperate character by the name of David Buckhart attempted to breakup the meeting, but James Havens, the Presiding Elder, who was on the ground, conquered the hoodlum, after a desperate struggle, and he was confined in the county jail. As Buckhart entered the jail door, he was heard to say, "Has it come to this, that David Buckhart has been whipped by a Methodist preacher." 37

Two resolutions passed by the Indiana conference during the thirties, bearing on the liquor and tobacco questions, are of interest. In 1835 a resolution was adopted requesting the General Conference at its next

33 Ibid., September 16, 1836 .

34 Holliday, "Indiana Methodism," 113.

35 Western Christian Advocate, November 25, 1836.

36 Ibid., september $23,1836$.

37 J. C. Smith, "Early Methodism in Indiana." 68-70. 
session to restore to the discipline Mr. Wesley's original rule on the subject of ardent spirits. This rule prohibits "drunkenness, buying or selling of spirituous liquors, or drinking them, unless in cases of extreme necessity."38 For some reason this rule had early been abandoned by the Methodist Church in America, and at this time only ministers were forbidden the buying or selling of liquors, members being permitted its sale, provided they permitted no disorderly conduct on their premises. ${ }^{39}$ It was not an uncommon thing for Methodists, in good standing, to run distilleries and deal in liquor. On one occasion Joseph Tarkington was conducting a "speaking meeting" on the Centerville circuit, "when a well-to-do Methodist farmer and distiller arose to speak. He began by saying, 'I have been governed by two spirits; one is the good-spirit, that prompts me to be good and to do good. The other is-.' Here Tarkington called out 'Whiskey!' at the top of his voice. 'No,' said the distiller, who was then quite under the influence of his home-made goods, as he often was, 'No; nobody ever saw me drunk.' 'Some people never get drunk-it always stands up in them,' replied Tarkington, and the half drunken Methodist distiller took his seat." This rude treatment evidently was the thing the Methodist whiskey dealer needed, for within six months he abandoned his distillery, and became a total abstainer. ${ }^{40}$ Dram drinking was not uncommon among the preachers themselves, though it had been much more practiced in previous years than it was in the thirties and forties. Peter Cartwright, in his account of his trip to the General Conference of 1824, held in Baltimore, in the company of Jesse Walker, Samuel Thompson and a certain F. S., says that at every stop F. S. and Walker called for spirits.

38 Minutes of Indiana Conference, 1835. The Ohio Conference passed a similar resolution at their session in 1835 .

39 Western Christian Advocate, September 18, 1835.

40 Tarkington, Autohiography, 26-27. 
Cartwright and Thompson protested, but the other two preachers defended the practice, whereupon Cartwright and Thompson threatened to quit their company if they did not stop using liquor for this time at least. ${ }^{41}$

In the early pioneer days the drinking of whiskey "in family and social circles was considered harmless and allowable sociabilities. It was almost universally the custom for preachers, in common with others, to take drams, and if a man would not have it in his family, his harvest, his house raisings, log rollings, weddings and so on, he was considered parsimonious and unsociable; and many, even professors of christianity, would not help a man if he did not have spirits and treat the company." 42 About 1825, however, a great temperance movement began, and agitation in favor of temperance spread all over the country. In 1835 a National Temperance convention was held, and the various states held state temperance conventions, in all of which the Methodists were active, and as a result of the movement several states adopted prohibition laws, and the drinking of liquor became much less common than before. ${ }^{43}$

The Indiana conference at its session in 1836 passed a resolution "that during the session of this conference none of its members is to use tobacco or defile the floor by spitting, and every brother is particularly requested to avoid it." From the text of this resolution we may infer that tobacco using, particularly the chewing of tobacco, was common among the preachers. The Western Christian Advocate, in one of its issues in 1835 , prints a clipping from another religious paper, in which the writer protests against tobacco spitting ministers, and gives as an instance, one young preacher

+1 leter Cartwright, Autobiography, 212-214.

42 Ibid., 212.

$4: 3$ Fish, "The revelopment of American Nitionality" $257-289$. 
who "spat as often as once in two minutes during his whole sermon, so that the pulpit floor was as filthy as a stable when he finished his discourse." +4

The sixth session of the Indiana Conference met at New Albany on October 27, 1837, with Bishop Soule as the presiding officer. The reports of the preachers from their circuits showed a gain of 3,140 in the membership, making the total for the conference of 31,058 ; and 116 preachers received appointments. This year there were four agents appointed for Indiana Asbury University, William Shanks, S. C. Cooper, William M. Dailey and John A. Brouse, the first agents, John C. Smith and Aaron Wood, having been appointed the year previous. ${ }^{45}$ At this session of the conference one man was refused admittance on the ground of his poor family government and the deficient moral education of his children. ${ }^{46}$ At this session John Ray and S. L. Robinson were reported to have died during the year. John Ray was born in Virginia, in 1768, and began preaching in Kentucky in 1790, but marrying soon afterwards, he located, as most of the early frontier Methodist preachers did, when they married. In 1819 he re-entered the ministry in Kentucky and served circuits there until he was superannuated, when he was transferred to the Indiana conference, in order to be near his son, Edwin Ray. ${ }^{47}$ John Ray was always much interested in the negroes and was a strong antislavery advocate, and the last act of his life was to give $\$ 50.00$ to the American Colonization Society, and $\$ 50.00$ for the redemption of James Thompson, a slave, who understood the Wyandotte tongue and who had

44 Western ('hristian Advocite, November 13, 1835, from "The Religions Ilerihl." The conference of 1843 passed the resolution, "Resolved, That by precept and example, we will use our influence to prevent the nse of tobacco in our houses of worship."

45 Minutes of conferences. Vol. II (1829-1839), 509-510.

46 Western Christian Arrocate, May 26, 1sis.

47 simutes of conference, Vol. II. 572. 
been acting as an interpreter in the Methodist Wyandotte mission. The Western Christian Advocate urged his purchase, in order to prevent his sale, and this was finally accomplished for $\$ 1,200.4 \mathrm{~s}$

To the conference in New Albany, in 1837, most of the preachers from the eastern part of the state came by way of the Ohio river, and many of them returned the same way. After the close of the conference some forty or fifty preachers, and among them Bishop Soule, were passengers on board the mail boat, the General Pike, running between Louisville and Cincinnati. On board the boat also was a large company of gamblers, returning from the Louisville races, which had just closed, and they soon took possession of the gentlemen's cabin, which was soon lined with card tables, and liquor began to flow in abundance. The scene was too much for Bishop Soule, and he rose from his seat and walked about in an excited manner surveying the scene, and in the midst of the bacchanalian songs and coarse jests, he called upon the preachers to gather in a group, and they began to sing:

\section{"Jesus, the name high over all, In hell, or earth, or sky; Angels and men before it fall, And devils fear and fly."}

This soon proved to be the correct remedy for the situation, for by the time the Methodist preachers had sung several hymns, the astonished gamblers had all retired from their card tables, to the decks and state rooms, and the remainder of the journey was spent in quietness. ${ }^{49}$

The seventh session of the Indiana conference convened at Rockville, on October 17, 1838, and the largest

4s Western Christian Adrocate. Mareh 10, 16:3 ; Ibirl. March 17. 1837 .

4!) Hollitlay. Indi:ma Methodism, 119-120. 
gain in membership yet recorded, was reported, 4,220, and also the greatest number was received on trial into the conference, 32. This year a new district appears in the minutes, the Logansport, over which George IH. Beswick was appointed Presiding Elder. The district included the following appointments, Logansport, Moniticello, Independence, Delphi, Peru, Fort Wayne, Warsaw mission and Rochester mission. ${ }^{50}$ At this session of the conference the preachers along the Ohio river had to travel across the state on horse back. Enoch G. Wood and F. C. Holliday made the journey from Indianapolis together. They started from Indianapolis on Saturday morning and arrived in Danville for dinner. Here Wood was taken sick, and they were compelled to remain until Monday, and Holliday improved the Sabbath by preaching twice in the court house. They resumed their journey on Monday, and reached Greencastle in time for dinner. Monday night they stayed at a double log-cabin, and during the night there was a tremendous racket in the yard, the master of the cabin and his dog engaged in fighting some wild animal, but the preachers were so tired with their travel, they did not arise to assist in the fight. In the morning the farmer informed them that a bear had gotten into his hog pen and was attempting to carry off a hog, and he had succeeded in saving the hogs, but the bear had escaped. The preachers were sorry they had not been called to his assistance, as the capture of it bear on the way to conference would have been id romantic incident, and would have made a good story to relate to their brethren. ${ }^{51}$

The year had been a fruitful one of ingathering, and many conversions and accessions were reported from all over the state. Joseph Tarkington, that year, the preacher at Lawrenceburg station, received some

5 Minutes of conferences, Vol. II. 595, 596.

51 Holliday. Indiana Methodism, 125- 126. 
two hundred into the Church, among them being some of the best people of the town. Ninety-eight were baptised in the church and twenty-eight in the Ohio river, those being baptised in the river, were of course immersed.5: On the Kalamazoo circuit two protracted meetings were held during the winter, and resulted in not only adding a number of members to the circuit, but in raising a subscription of $\$ 1,000$ for the building of a meeting house. At Shelbyville, Danville, Rising Sun, Elkhart, Rushville, Pine Creek, Lagrange, New Albany, and on many other circuits successful revivals were conducted, resulting in the bringing of many new members into the Church. ${ }^{53}$ Allen Wiley, the Presiding Elder of the Crawfordsville district in 1837-38, reports that his district contains 4,000 square miles, that it includes ten "city towns" three of which contain a population of 2,000 , and that in this territory there are 60,000 inhabitants, 3,000 church members, and 12,000 people who attend Church, but are not members. $\mathrm{He}$ complains that there are no places large enough to accomodate the crowds who come to the Church services, which he says is due to the newness of the country. ${ }^{54}$

The conference which met in Lawrenceburg in 1839 was a very interesting and important meeting. In the first place there were three bishops present, Bishops Roberts and Soules being visitors and Bishop Morris the president of the conference. There were thirty-one preachers received on trial, and twenty-one received into full connection, and an increase of 8,694 members was reported for the conference. It was also the year in which General Conference delegates were elected, and Allen Wiley, E. R. Ames, C. W. Ruter, A. Eddy,

52 Tarkington, Autobiography, 134-135.

5.) Accounts of these revivals will be found in the Westem ('hristian Advocate for 1838 .

54 Western Christian Advorite, 17t. 14s. 
and A. Wood were duly elected to represent the conference.

The preachers with few exceptions, came to the conference cloathed in home-spun, and all of them except a few who lived along the Ohio river came to the conference on horse back, and most of them were seedy when they arrived. "Many had come from a month's tussle with the ague, and some of them kept up the shake habit every other day during conference." During the latter part of the conference session a resolution was introduced requesting that the preachers return to the original plainness of dress, and that they be requested to wear either the round breasted or plain frock coats. The reason for this resolution, was the fact that John S. Bayless having married a well-to-do woman of Vincennes, had come to conference wearing his wedding suit, which was tailor made and in the height of fashion; the pants tight with narrow falls; the coat was "pigeon tailed" and the hat a stove-pipe, the whole giving the wearer a unique appearance in a Methodist conference of that period in Indiana.5i But more and more after this conference the preachers dressed as they pleased, though this motion was passed without a dissenting vote, and a few years later a similar resolution was introduced, and passed.

One of the important parts of a Methodist conference's business is the examination of character. Not only were those just entering the conference examined, in this regard, but each year the characters of every member of the conference had to be "passed." Especially were those, who were up for admission into full connection, given a careful examination. One case which came before the conference of 1839 was especially interesting. The young man under consideration was William J. Forbes, who was just closing his second year as a probationer, and therefore if he was

55 Tarkington, Autohiography, 12-22. 
found deserving he might be admitted. The committee on his studies gave a very complimentary report. He was good on everything, and very good on several. Finally the Presiding Elder, under whom he had been traveling, reported that this young man was a very good preacher, and the people liked to hear him. $\mathrm{He}$ also reported that he read a great deal and understood what he read, but he said, no one is converted under his preaching. At this juncture up jumped James Havens, and asked, "Does he make anybody mad?" 'To this the Elder replied, "O no! He is a sweet tempered man, everybody loves him." "Then I'm opposed to him," said Havens. "A man under whose preaching nobody is converted and nobody made mad is not fit for a Methodist preacher." In spite, however, of James Havens' opposition Forbes was admitted, for, said the Bishop, "A young man that reads a great deal and understands what he reads and preaches well, and that everybody loves, is a safe case." 56

In this early day a college education was an actual disadvantage to a preacher, as far as gaining advancement was concerned. Thomas A. Goodwin was the first preacher to enter the conference with a college diploma. The presiding elders were afraid of showing too much favor to a college man, and on a number of occasions Goodwin was actually demoted for no other reason than that he was a college graduate. One of Goodwin's colleagues was a man very deficient in education, but was much more popular on the circuit, "chiefly because he could outshout me." "He got all the socks, but he generously divided with me, for he got more than twice as many as he could possibly wear out. He would put up for the night or for a week, as the demands of the appointments would allow. and smoke his pipe, and talk gossip, but read, never, beyond

5f; Takington. Autohiography, T. A. Goodwin Introduction, $15,16$. 
the Western Christian Advocate. I met his praise everywhere I went. He kissed all the babies and had several namesakes before the year was half out." This situation, and the jealousy and prejudice against college graduates finally drove Thomas A. Goodwin out of the regular ministry of the Methodist Church, and he became an editor of a newspaper, the chief policy of which was to fight the saloon and slavery. ${ }^{57}$

One of the most notable events of the session of 1839 was the first appearance of Dr. Matthew Simpson, the young president of Indiana Asbury University. At the time he was a young man, less than thirty years of age, and his personal appearance was not very prepossessing. He was clothed in neat, well-fitting jeans, although a number of others wore store clothes, and his dress and appearance was disappointing to the conference. The opportunity, however, for him to distinguish himself as a preacher, came when he was appointed to preach the anniversary sermon before the conference. This was the year that marked the centenary of Methodism, the first Methodist classes having been organized by John Wesley, in London in the year 1739. When the time came for the anniversary sermon, the house was crowded. The preacher took for his text the vision of Ezekiel, in which the prophet sees the waters flowing from the sanctuary. It was a sermon which described the triumph of the gospel, a theme which naturaliy greatly appealed to a Methodist conference, and which gave President Simpson opportunity of bringing into play his remarkable descriptive powers, and his rich imagination. The effect of that sermon was most impressive. Many preachers were overcome with emotion, and at one of the "climaxes," an intelligent lady, not usually excitable, jumped to her feet, waving her parasol, and looking upward exclaimed, "Sun, stand thou still, and let the moon pass by," re-

57 Ibid., 51-60. 
peating the sentence until some one started to sing, while her immediate friends took her out of the congregation." 5 s After this Dr. Simpson was voted the prince of preachers, and to the day of his death Indiana Methodism never reversed that opinion.

The reading of the appointments in these early days was a time of intense excitement for the preachers; the preachers had no inkling, in those days, as they have in these, as to where they were to be sent, and to move then meant much more than it does now. We will let one who was an eye witness describe the reading of the appointments at the session of 1839. "Many of the preachers had bidden good-bye to their entertainers, and their horses, after a week's rest, were saddled and at the door ready to make a few miles homeward that day. A presiding elder stood in each aisle of the church, and the order was announced by the bishop that when the name of a circuit was announced there would be a pause, and the preacher for the preceding year should stand up, and the presiding elder nearest to him would go to him and receive from him the "plan of the circuit." This occupied usually less than a minute, but to the conference it seemed an age. Not a word was spoken until this part was completed. The preacher stood up as directed, and the Presiding Elder went to him; but not until the Bishop saw that the "plan" was handed over, would he break silence. Then followed the name of the new preacher. It was usually a disappointment. Naturally enough he hoped it would not be a long move, the quality of the circuit being secondary; for there was not so much difierence in quality as might be supposed, as none were easy." 59

While the appointments were being slowly read at this session of the conference James V. Watson, who

58 Tarkington, Autobiography, 17-19.

69 Tarkington. Autobiography. Goodwin's Introduction, 19-22. 
had been on the superannuated roll the year previous, sat listening with intense anxiety for his appointment. He had hoped to be sent to Lawrenceburg, for he harl assisted in a series of meetings there, and had many friends in the charge who desired that he be their preacher. But Madison district was read and Lawrenceburg had another preacher, and the bishop read on and on. Finally all the Indiana districts had been read and the bishop announced the Michigan district, and among the first appointments read in that district was "White Pigeon, James V. Watson." Watson sprang to his feet and with a great display of excitement exclaimed, "Where is White Pigeon? Can any one tell me where White Pigeon is?" "You will find it in Michigan, Brother Watson," coolly answered the Bishop. Finally after the conference was over Willism W. Hibben and S. C. Cooper took him by the arms, nne on each side, and as they walked up the street Cooper told what a beauty of a place White Pigeon was, and that they had a fine brick church with a basement, and that the people would drive ten miles in their sleighs to hear him preach. And with such encouragement Watson's discouragement and rebellion passed and he said, "I will go: I will start tomorrow morning. Hurrah for White Pigeon." And he went to White Pigeon, and "he wrote his name in letters of immortal memory all over the great northwest." 60 For after serving White Pigeon he became pastor at Detroit and other import. ant cities, and finally became the first editor of the Northwestern Christian Advocate. "Who shall say that, after all, the hand of the Lord was not in that cruel move."

When the preachers came to the conference in October, 1840, at Indianapolis, there were 153 traveling preachers, 418 local preachers, and 52,626 communi-

60 Western Christian Advocate. June 30, 1858. Article by $\Pi$. W. Hibben. 
cants, an increase of 9,116 over the previous year. The year had been one of prosperity for the church, for the spirit of revival had continued throughout the year. On the Newton circuit more than three hundred joined the Church; Rockport reported a similar number of acce:ssions, and a great "sweeping revival." J. B. Birt on the Mooresville circuit received four hundred members on probation and by letter, and during the year meeting was established for the first time at Plainfield. Aaron Wood of the Laporte district tells of holding two quarteriy meetings in barns, and three on cainpmeeting grounds, where many thousands have attended. During the summer a camp-meeting was held near the "little modest town of Lebanon," and a writer describes "this settlement" as having shared more largely in the great blessings of Methodism, than any other, which he has seen in the Wabash valley, "and its peculiar tendency to make men sober, industrious, kind and devotional, is here distinctly visible." Meetings were also reported from the Independence, Centerville, Brownstown, Warsaw mission, Deep River mission, Evansville, Brookville, and from many other circuits and stations. Augustus Eddy from Indianapolis district reports more than 1,500 added to the Church since conference, "embracing all ranks and stations in society." ${ }_{11}$ "Revival power like a tidal wave was rolling over the country."62

These were years of rapid growth, in the number of members, circuits and districts. At the conference of 1840 eleven districts were formed, as follows: Madison, Charlestown, Indianapolis, Vincennes, Crawfordsville, Greencastle, Bloomington, Connersville, Winchester, Logansport and South Bend. The list of the presiding

61 Accounts of many such revival meetings will be found in the Western Christian Advocate for 1840.

62 J. L. Smith. Indiana Methodism, 36-39. 74, 75. 
elders included Calvin W. Ruter, Enoch G. Wood, James Havens, Henry S. Talbott, Thomas J. Brown, Allen Wiley, John Miller, Augustus Eddy, Robert Burns, George M. Beswick and Aaron Wood. The number of circuits and stations in each district ranged from eight to eleven, and the whole state was now completely covered by these eleven Presiding Elders districts. ${ }^{63}$ The conference at its session in 1839 had asked the General Conference to make the northern boundary of state the northern boundary of the conference, and accordingly provision was made for the organization of the Michigan conference by the General Conference of 1840 .

In the latter thirties Methodist work was begun among the Germans, who were beginning to come into the state in considerable numbers. The unsuccessful political revolutions in Europe during the year 1830 sent many disappointed Germans into the United States, and they kept coming into the central states in a continuous stream until the opening of the Civil War. In 1839 it was reported that four hundred had been converted and joined the Methodist Church, in various places in the country, and in 1840 the first German mission was established in Indiana, at Lawrenceburg, and John Kisling and M. J. Bofer were appointed missionaries. The German work prospered and the next year three German missions were reported, one at New Albany, one at Fort Wayne, beside the Lawrenceburg mission. The next two years the New Albany and Fort Wayne mission disappear, but new German work is begun at Evansville. ${ }^{64}$

Seventy-five years ago there was much less harmony among the denominations, and far more rivalry and jealously than now, and debates between the champions

6:3 Minutes of Conferences. Vol. III (1S8!-1S45). 10!), 110. 111. tif Ibid., Western Christian Adrocate, page 5t: 1sas. 
of the various rival churches were common. Not only were there arguments and debates between the preachers, but the people were well versed in the peculiar doctrinal position of their particular denomination, and embraced every opportunity of defending it. The Methodists had strenuous debates with the "Campbellites," the Presbyterians, and the Baptists, but all the denominations united against the Universalist. In the forties there were several large debates held in the old court house at Martinsville between the Universalist leader of the West, Rev. Erasmus Manford, and James Scott, a Methodist preacher. Manford declared that all mankind would finally reach holiness and happiness, while Scott affirmed the endless punishment of the unrepentant wicked. At the close of the three days' debate Manford painted a hell for Scott and his brethren to look at, *** then flung into it all the human race that orthodoxy excluded from Heaven. *** Scott retaliated by sending Judas to Heaven before his Lord, and by carrying all liars and lechers, seducers and murderers, to Abraham's bosom," all bedeviled and unrepentant as they were." Manford replied that Mr. Scott need not worry himself about heavenly society, for all would be purified by the offering of Christ.

The debate was followed up by the Methodists with a revival, at which many seekers sought pardon at the altar, and at its conclusion a long list of probationers was turned over to the class leaders. At the end of the probationary period, however, the list had shrunk, "for the temptations to former habits and amusements which were forbidden in the Discipline were too great for their self-denial. *** They had most willfully listened to the enchanting music of the violin, which was not at all commendable; for in those days, it was thought by many that more devils lurked in catgut and horsehair than Luther ever dreamed of. The Baptists, Presbyterians and Christians were all in accord with 
the Methodists in denouncing "fiddling and dancing and gumsucking parties." 64

The tenth session of the Indiana conference met at Terre Haute, October 6, 1841, and was presided over by Bishop Roberts. This was the last time the venerable Bishop, now the senior Bishop of the Church, was to preside over an Indiana conference. For over twenty years Bishop Roberts had been a resident of Indiana, having moved to Lawrence county, Indiana, from Shenango, Pennsylvania, in 1819. He had been elected to the episcopacy by the General Conference of 1816 , the very year of Asbury's death, and was the first married bishop of the Methodist Episcopal Church. Bishop Roberts being the first married bishop, the General Conference which elected him, passed a resolution, making it the duty of the Book Committee at New York, to decide what sum was to go to married Bishops for family expenses. This was done until 1832 when the rule was so changed as to make it the duty of the annual conference in which a Bishop resided, to estimate the "table expenses." Thus at each of its sessions since 1832 the Indiana conference had appointed a committee to estimate the "table expenses" of Bishop Roberts. From 1816 to 1832 Bishop Roberts had received the sum of $\$ 200$ living expenses; from 1832 to 1836 he received $\$ 250$; from 1836 to $1840, \$ 300$; and from 1840 to his death in 1843 , the annual sum received was $\$ 400$. Besides this the Bishop received a quarterage $\$ 200$ yearly, which was contributed by all the Conferences. ${ }^{65}$

Duxing these years of residence in Indiana, Bishop Roberts had greatly endeared himself to the Methodists of the state, and as old age approached the Indiana Conference became solicitous for his comfort, and at

64 Memoirs of Noih J. Major, "The Pioneers of Morgin County." Edited ly Login Esarey, 343-348.

tis Charles Elliott, Life of Roberts, 359. 
the session of the conference in 1839 resolutions were ofiered by C. W. Ruter, and Allen Wiley, which were unanimously passed, requesting Bishop Roberts to remove to some more prominent place in the state, where his brethren and friends could more easily have access to him, and thus render him such attention, as the Church felt anxious that he should receive. Bishop Roberts, however, refused to leave his farm in Lawrence county, and form new neighborhood alliances. ${ }^{66}$ Again at the session of the conference at Terre Haute, in 1841 , a Resolution was offered and passed requesting "That our venerable and beloved Superintendent, Bishop Roberts, be, and is hereby requested, at his first convenient opportunity, to sit for his portrait, and that the preachers of this conference be permitted to defray the expense which may accrue in obtaining such portrait." 67 When this resolution was passed Bishop Roberts related the following anecdote of Bishop Asbury. When the Philadelphia conference offered a similar resolution, in view of getting Bishop Asbury's portrait, he told them, if they ever got his portrait they would have to go to "Paradise" for it. The brethren thought the Bishop altogether unreasonable, and insisted that it was a duty he owed the Church and posterity, to sit for his portrait. "Well," said Bishop Asbury, with an indifferent air, "all I have to say is if you ever get my portrait, you will have to go to "Paradise' to get it. $\mathrm{He}$ is the best artist I know of in America."68 Mr. Paradise resided in New York, and of course the portrait was taken.

Bishop Roberts, probably, would have taken no step to have his portrait painted had it not been for a letter addressed to him by Dr. Matthew Simpson and E. R. Ames, urging him to come to Greencastle in July, 1842,

t56 Ibid., 336. Minutes for 1839.

67 Minutes, $18+1$.

to Western Christinn Advocate, Angust 11. 15. 
to sit for his portrait. Accordingly everything was arranged and the Bishop spent two weeks in Greencastle, and during his stay his portrait was painted, and Dr. Simpson wrote down, from the Bishop's own mouth, a brief outline of his early life, intending to write the life of the Bishop, but these notes were afterwards used by the Bishop's biographer, Dr. Charles Elliott. ${ }^{69}$ The portrait then painted was a life-sized picture, and for many years hung in the old chapel of Indiana Asbury University, but in the fire which partially consumed that building, in 1878 , the picture was cut out of the frame and is now hanging in the east gallery of Meharry Hall of DePauw University.

The conference of 1842 was held in Centerville, presided over by Bishop Morris. The conference was still growing rapidly and an increase of 9,562 members was reported, twenty-seven preachers were admitted on trial, and when the appointments were read 180 preachers were appointed to charges. Among the interesting occurrances of this conference was a sermon by J. B. Finley, of the Ohio conference. He was known as the "old chief" and was unsparing in his denunciations of gold watches, jewelry and all clerical foppery, and the preachers' wives, who sported jewelry, where much incensed at his denunciations. ${ }^{70}$ The sermon of this old warrior, before the Indiana conference on this occasion made a powerful impression. The Church was a new one and was packed to the doors, and down in front sat James Havens, then known as "Father Havens." Finley told of his experiences as a missionary among the Wyandotte Indians, and his accounts of remarkable conversions and triumphant deaths among them were thrilling beyond comparison. Among other things he told of his first attempt to preach, when he tried to read one of his father's sermons, his father being a

69 Elliott, Life of Roberts, 349-351.

70 Western Christian Advocate. September 1. 1858. 
Presbyterian minister, but the sermon was not a success. Then he said, "I dropped on my knees and called upon God to help me, and help me now." And his stammering tongue was loosed, and he shouted and exhorted, and prayed, and that first sermon resulted in the conversion of one person. "He was a stripling, an awkward, green boy. He came to Indiana: God called him to preach; he is now a son of thunder. He was not afraid of Indians. Scalping knives and tomahawks did not frighten him. He blazed his way through the woods of Indiana. He became familiar with the growl of the bear and the scream of the panther. He is now a veteran leader among you: he is here tonight-there he sits!" pointing to James Havens. The scene which followed beggars description. Havens sprang from the altar to the pulpit, to embrace the "old chief" in his arms, and the people shouted and screamed. ${ }^{71}$

The last session of the old Indiana conference convened in the Old School Presbyterian Church in Crawfordsville, on October 18, 1843, Bishop James O. Andrew, presiding. It was the conference at which General Conference delegates were to be selected, and a deep current of anti-slavery sentiment was manifest among the preachers. Since the General Conference of 1840, anti-slavery sentiment had greatly increased in the Church at the North. Only eight years before in the General Conference of 1836, which met in Cincinnati, a resolution was introduced and passed by an overwhelming vote, condemning "Modern abolitionism, and wholly disclaiming any right, wish or intention to interfere in the civil and political relation between master and slave as it exists in the slave-holding states of the Union." The Bishops in their pastoral letters the same year exhort all "to abstain from all abolition movements and associations and to refrain from patronizing any of their publications." Between 1836

71 J. L. Smith, Indiana Methodism, ৪5-\&৪. 
and 1840 a number of preachers were brought to trial before their respective conferences because of their abolitionism, and the Philadelphia conference for ten years after 1837, asked each candidate for admission into the conference, "Are you an abolitionist?" and unless this question was answered in the negative he was not received. The incident which was the direct cause for the increase of anti-slavery sentiment in the Church, was the action of a Maryland pro-slavery convention which met in the winter of 1841-1842. This convention passed resolutions asking the Maryland Legislature to pass a law which would result in either driving the free negroes from the state or reducing them to bondage. This action greatly aroused the Methodists all over the North, because many of the free negroes were Methodists. ${ }^{* 2}$

This convention was discussed in all the Church papers, and the notice of the convention in the Christian Advocate and Journal of New York, created such alaim at the South, that predictions were made, if it continued to take part in the slavery discussion the paper would not circulate in the South. ${ }^{73}$

The delegates elected by the Indiana conference of 1843 to the General Conference of 1844, were Matthew Simpson, A. Wiley, E. R. Ames, John Miller, C. W. Ruter, Aaron Wood, Augustus Eddy and James Havens with John C. Smith and Richard Hargrave as reserve delegates. Two of these men elected as General Conference delegates were afterwards to become bishops, Matthew Simpson and E. R. Ames, both elected on the same ballot by the General Conference of 1852, and both became conspicuous leaders of the Church and the nation during the critical period of the Civil War.

The most important question before this last session of the old Indiana conference was the one relating to

i2 Sweet, Nethodist Episcolal Chureh and the Civil War. 20-24. 7: Charles Elliott, The Great Secession. 237, 239. 
the division of the conference. The conference was fast becoming unwieldy, each year there having been large increase in the membership; and the whole state was now dotted with circuits and stations. At the close of this session there were 16 districts, 148 circuits and stations, and over 200 ministers. The conference of 1842 had taken action on the matter of division and resolutions, favoring it had been passed. After considerable discussion a number of resolutions respecting division were adopted. The boundary between the conferences was to be the National road, with the provision that the Eastern charge in Indianapolis, now Roberts Park Church, with all the towns on the road east, were to be placed in the Northern Conference, while the Western charge, now Meridian Street Church, with all the towns west on the National road, were to be placed in the Southern Conference, except Terre Haute, which was placed in the Northern Conference. The conference also provided that the Southern conference was to be known as the Indiana conference, and the Northern division of the North Indiana Conference.

Bishop Roberts had died March 26, 1843, and it was fitting that the old Indiana conference at its last session should take appropriate notice of his death. Early in the session a committee consisting of C. W. Ruter, Matthew Simpson and Allen Wiley was appointed to draft appropriate resolutions, and later in the session they reported in a series of nine resolutions. Among the resolutions were several resolving that the remains of Bishop Roberts, which had been buried on his farm, should be removed to Greencastle; and that a suitable monument should be erected over the body, to be paid for by the Indiana conference; and that Bishop Soule should be requested to furnish the epitaph for the tomb. These resolutions were afterwards carried out to the letter, and in 1844 the remains of Bishop Roberts were removed to the campus of Indiana Asbury University, 


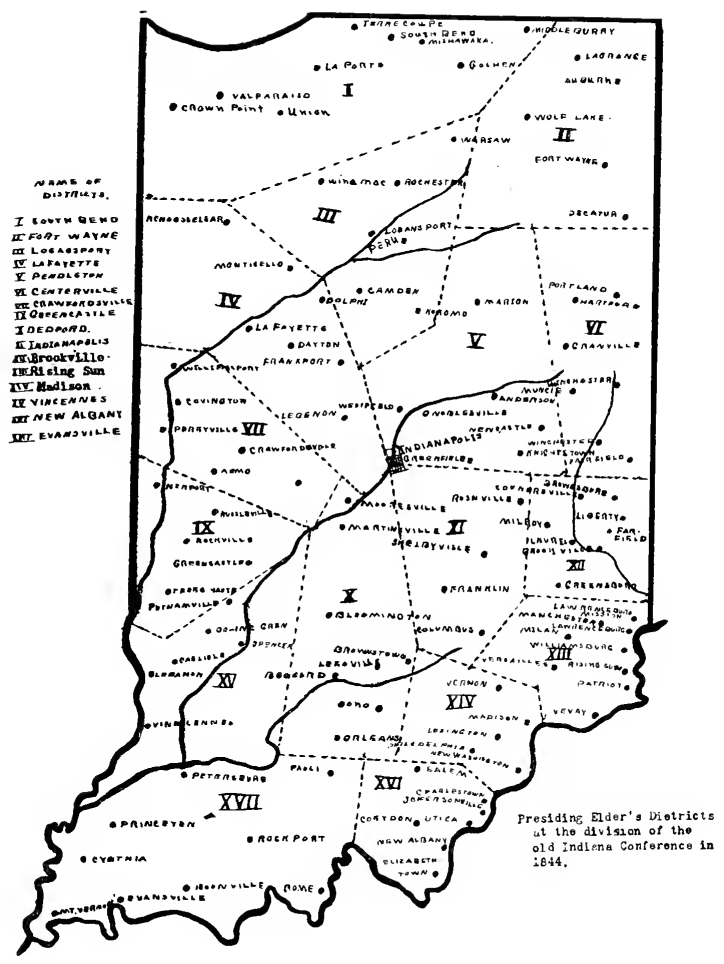



at Greencastle, and later a suitable monument was erected over the spot, upon which was engraved the inscription furnished by Bishop Soule, where it can be seen to this day.

The General Conference of 1844 , which met in New York, divided the Indiana Conference into the Northern and Southern divisions, as the conference itself had asked, and with this division, we bring this account to a close. 
PART II.

MINUTES OF THE INDIANA CONFERENCE 1832-1844.

First Session of the Indiana Conference, New Albany, October, 1832.

JOURNAL of the first annual session of the Indiana conference of the Methodist Episcopal Church, held in New Albany, Floyd county, Indiana, commencing on the 17th of October, 1832.

Wednesday morning, nine o'clock, conference met according to appointment and was opened by Bishop Soule by reading a portion of the sacred Scriptures, singing and prayer.

The list was called and the following members being present, answered to their names: Allen Wiley, Joseph Tarkington, John Kern, Daniel Anderson, Samuel C. Cooper, George Locke, James Havens, Asa Beck, Charles Bonner, John T. Johnson, William Shanks, C. W. Ruter, James Armstrong, William H. Smith, Enoch G. Wood, James Scott, Richard S. Robinson, Boyd Phelps.

Bishop Soule in the chair, conference proceeded to business. C. W. Ruter was nominated and elected secretary.

Conference voted the time of meeting and adjournment as follows: At one-half past $8 \mathrm{a} . \mathrm{m}$. to meet, and adjourn at $12 \mathrm{~m}$. To meet at 2 o'clock p. m. and adjourn at $5 \mathrm{p} . \mathrm{m}$.

William Shanks and C. W. Ruter were appointed a committee to appoint the preachers to officiate, and superintend the congregations during the present session of the conference. 
Brothers James Scott, A. Wiley and William Shanks were elected conference stewards. Bros. A. Wiley, E. R. Ames and James Armstrong were appointed a committee to write the memoirs of the dead.

Bros. George Locke, E. G. Wood and James Scott were nominated and elected a book committee.

Bros. C. W. Ruter, J. Armstrong and D. Anderson were appointed a committee to draft by-laws for this conference and report as soon as convenient.

Bros. C. W. Ruter, A. Wiley and James Armstrong were appointed a committee to take into consideration the propriety of building a conference seminary, and report as soon as convenient.

Conference proceeded to the consideration of the first question on the minutes, viz: Who are admitted on trial? Answer, John Daniel, Henry Deputy were recommended from Charlestown district and admitted. Thomas Nicholson and David Stucker not admitted, but the Presiding Elder is permitted to employ them should he deem it expedient. David Stiver, Elijah Whitten recommended from Madison district, were admitted. Stephen R. Ball and Joseph White recommended from Crawfordsville district were admitted, but I. W. McEwing was not admitted; the Presiding Elder has leave to employ him when he thinks proper.

Jesse Harbin recommended from Wabash district not admitted. But the Presiding Elder has liberty to employ him if necessary. Moses Ashworth recommended for readmission was not admitted. Conference voted that the Presiding Elder have liberty to employ Isham West, should his labors be deemed necessary.

Conference proceeded to the consideration of the second question on the minutes: Who remain on trial? The characters of G. W. Beswick, Nathan Fairchild, William M. Daily, James T. Robe and Cornelius Swank were severally examined and continued on trial.

On motion, resolved, that during the examination 
of characters, the conference sit with closed doors. On motion, resolved that the preachers on trial be permitted to sit in the conference room.

Conference proceeded to the examination of the characters of Deacons. The character of Richard L. Robinson, Samuel Brinton, John A. Decker, Boyd Phelps, Asa Beck, Miles Huffaker and Charles Bonner were severally examined, approved, and passed.

Conference proceeded to the consideration and election of candidates for Elders Orders, and Samuel Julian was elected. Whereupon conference adjourned.

Wednesday 2 o'clock p. m. Conference met pursuant to adjournment, and was opened according to rule. The list was called, journal read, and approved. Conference proceeded to business. Bishop Soule in the chair. On motion the Presiding Elder has liberty to employ David Stucker if necessary.

Conference resumed the consideration of the first question on the minutes, and Robert Johnson was recommended from Madison district, was admitted on trial. Conference resumed the consideration of the character of Deacons of one year. And the case of A. W. Arrington was presented and his Presiding Elder observed that, he had withdrawn from the connection, having become skeptical in his mind; and read part of a letter from said Arrington, in which he acknowledged his errors, stated, that he had become thoroughly convinced of the truth of Christianity, and deeply deplored his fall, and begged to be restored to his former standing in the Church. ${ }^{1}$

A communication was also read from him to the Bishop, and members of Illinois Conference containing

1 Alfred W. Arrington was reputed as one of the most eloquent young preachers in Indiana, and was much admired and flattered, and his fall was due to dizzy head, from too much flattery. He was restored to the Conference, but soon fell again, and finally became a lawyer in the State of Arkansas. (Article by W. W. Hibben, Western Christian Advocate, April 28, 1858.) 
a humble confession of his errors, and fall, and soliciting pardon and restoration: whereupon a motion was made, that A. W. Arrington be restored to his former standing in the conference. After some discussion, the vote was taken, was decided in the negative, and he was not restored.

On motion the vote taken in the case of Moses Ashworth" was reconsidered; and on the question being taken, shall he be readmitted? - was decided in the negative.

Conference then proceeded to the examination of the characters of Elders A. Wiley, T. S. Hitt, I. T. Johnson, Joseph Oglesby, I. W. McReynolds, Joseph Tarkington, Robert Burns, (Superannuated) William Shanks, were examined, approved and passed. The name of William Moore was called, and it was announced that he died the past year in peace.

The characters of John Kerns, C. W. Ruter, John Miller and Michaels S. Taylor were severally examined, approved and passed. The character of John Strange was examined and passed; also received a superannuated relation. The name of Brother Benjamin C. Stevenson was called, when it was stated that he died the past year in peace.

The character of Eli P. Farmer was examined, approved and passed; he asked a location and it was moved that his request be granted; after discussion, his case was laid over for further consideration. James L. Thompson and D. Anderson were examined and passed. The President, C. W. Ruter, T. S. Hitt, I. L. Thompson, I. Miller and D. Anderson a committee to examine the candidates for admission into full connection. Whereupon conference adjourned.

Thursday, one-half past 8 a. m. conference met pur-

- Moses Ashworth was the first circuit preacher on the silrer creek circuit (1806), which wis the first complete circuit in Indiana territory. 
suant to adjournment, and was opened by reading the Scriptures, singing and prayer, the list was called, the journal read and approved. Conference proceeded to business. Bishop Soule in the chair.

On motion the case of A. W. Arrington was reconsidered on the resolution of his restoration to his former standing; after some considerable discussion, the vote was taken, and lost. A motion was then made that A. W. Arrington be restored to his standing as a member of the conference, but that his parchments be withheld and not allowed to exercise the office of a Deacon in the Church. The vote being taken was decided in the affirmative.

Conference resumed the examination of the character of Elders -, J. Armstrong, R. Hargrave, S. C. Cooper, William H. Smith, H. Vredenburgh, E. G. Wood, N. B. Grifith, J. Hadley, J. Havens, J. J. Brown, and J. Scott were severally examined, approved and passed, and Brother Scott's relation was changed from superannuated to that of supernumerary. Brother William Evans received a location at his own request. On motion, the case of T. Davis was laid over until Saturday. E. P. Farmer withdrew his request for a location. Conference resumed the first question on the minutes, and E. Wood was recommended from Crawfordsville district, was admitted on trial.

Several resolutions from the General (Conference) were read by the President on the subjects of the Sunday schools, Bible and Tract societies, and on motion, they were referred to a select committee of three and J. Havens, A. Wiley and J. Oglesby were elected that committee, and report the same as soon as practicable.

On motion a committee of three was appointed viz: William Shanks, M. S. Taylor and J. Armstrong to estimate the amount necessary for the table expenses of Bishop Roberts, to report as soon as convenient.

The committee appointed to draft By-laws presented 
their report, which was read, and adopted, and ordered to be journalized; the following is said report:

1st. The President to take the chair precisely at the hour to which the conference adjourned, and cause the same to be opened by reading (a portion of Sacred Scriptures) singing, and prayer. The list shall be called and the Journals of the preceeding session read and approved. When the conference shall proceed with the ordinary routine of business.

2nd. The President shall decide all questions of orders, subject to an appeal to the conference, but in case of such appeal, the question shall be taken without debate.

3rd. The President shall appoint all committees not especially otherwise ordered by the conference, but any member may decline serving on more than one committee at the same time.

4th. All motions, or resolutions introduced by any member shall be reduced to writing, if the President, Secretary, or any two members request it.

5 th. When a motion, or resolution, is made and seconded, or any report presented, and is read by the Secretary, or stated by the President, it shall be deemed in the possession of the conference, but any motion, or resolution may be withdrawn by the mover any time before decision, or amendment.

6th. No new motion, or resolution, shall be made until the one under consideration is disposed of, which may be done by adoption, or rejection, unless one of the following motions should intervene, which motions shall have precedence in the order which they are placed, viz: Indefinite postponement; lying on the table; reference to a committee; postponement to a given time, or amendment.

7 th. No member shall be interrupted when speaking, except by the president to call him to order, when he departs from the question, uses personalities, or dis- 
respectful language; but any member may call the attention of the president to the subject when he deems a speaker out of order; and any member may explain if he thinks himself misrepresented.

8th. When any member is about to speak in debate, or deliver any matter to the Conference he shall arise from his seat and respectfully address himself to the President.

9th. No person shall speak more than twice on the same subject, or question, and then only fifteen minutes at any time without leave from Conference. Nor shall any person speak more than once till every member choosing to speak, shall have spoken.

10th. When any motion or resolution shall have passed, it shall be in order for any member who voted in the majority to move a reconsideration.

11th. No member shall absent himself from the service of the Conference without leave, or unless he be sick or unable to attend.

12th. A substitute shall never be received for the original resolution unless with the consent of the mover, nor with his consent after the resolution shall have been amended.

13th. No member shall be allowed to vote on any question who is not within the bar at the time when such question is taken by the President, except by leave of the Conference when such member has been necessarily absent.

14th. Every member who shall be within the bar at the time the question is put, shall give his vote, unless the Conference for special reasons shall excuse him.

15th. No person shall present a charge or a complaint against any member of the Conference unless he shall have conversed previously with that member on the subject, and apprised him of his intention to lay it before the Conference. 
16th. A motion to adjourn shall always be in order, and shall be decided without debate.

All of which is respectfully submitted by your committee.

\section{W. RUTER, Chairman.}

Whereupon Conference adjourned.

Thursday, 2 o'clock p. m., Conference met pursuant to adjournment, and was opened according to rule. The list was called and Journal read and approved. Conference proceeded to business. Bishop Soule in the chair. The Conference Stewards spent some time in attending to the pecuniary concerns of the Conference. The Conference voted to draw on the book concern for $\$ 400$ and on the chartered fund for $\$ 75$. Conference then proceeded to take the numbers and found them to be twenty thousand and thirty-five.

The committee appointed on Bible, Sabbath School and Tract Societies, reported as follows: "The committee to whom was committed the report of the General Conference on the subject of Bible, Sunday Schools and Tract Societies, have had the same under consideration, and have to lament that our success in promoting said societies has not been commensurate with our capability of acting, and the means which divine Providence has put within our power. We hope, however, in the future, that we shall redeem in some measure, the time and means which are lost, by an increased endeavor to do our duty in time to come. In order to which, we recommend that this Conference require each preacher in charge of a Circuit or Station, in conjunction with his Presiding Elder to use his influence to form the Quarterly Conference of his Circuit or Station into a Bible Sunday School and Tract Society, auxiliary to these several societies of the Methodist Episcopal Church, and also to form as many subordinate or branch societies in his Circuit as in his power. 
We would also recommend that the Junior Preachers aid so far as they can in this good work.

We would recommend that if any preacher neglects his duty in this matter he be censured by the Conference as a man unfaithful to his trust as a Methodist preacher.

All of which is respectfully submitted. SAMUEL HAVENS, Chairman.

Said report was adopted, and ordered to be journalized and also a copy to be sent to New York for publication in the "Christian Advocate and Journal."

Conference resumed the first question on the minutes; and Elhannon Sweet recommended from Indianapolis District was not admitted; but the Presiding Elder has liberty to employ him if necessary. Amasa Johnson and Hiram Griggs recommended from Indianapolis district, were admitted. On motion, Bro. James Armstrong was appointed agent of this Conference to receive the bequest of Brother James Paxton (deceased) for the benefit of the Methodist Episcopal Church of Indiana. On motion Brother A. Wiley was appointed agent of this Conference to receive the bequest of Brother Isaac Swearingin (deceased) for the benefit of the Methodist Episcopal Church in the State of Indiana."

Whereupon Conference adjourned.

Friday, half-past eight o'clock a. m., Conference met pursuant to adjournment, and was opened according to rule. The list was called and Journals read and approved. Bishop Soule in the chair. Conference proceeded to business.

On motion, the vote that was taken making the case of Thomas Davis the order for the day on Saturday was reconsidered. The case of L. D. Smith was taken up, and his character passed.

3 These beruests were the real begimning of the Preachers' Aid Society. 
The case of J. A. Decker was called, his character passed, and at his own request received a location.

The committee appointed to estimate the amount necessary to defray the table expenses of Bishop Roberts presented their report as follows: $\$ 250$ per year, which report was adopted. ${ }^{4}$ On motion the Conference appointed the 15th of November next as the day of humiliation, fasting and prayer in the Methodist Episcopal Church in the State of Indiana, and that the editors of the several papers as published in the State, be respectfully requested to give notice of the same in their papers.

On motion, resolved, that his excellency, the Governor of the State of Indiana, be respectfully requested to appoint a day of fasting and prayer, to be observed throughout the state, in special reference to the alarming epidemic which threatens us.

Conference proceeded to the consideration of the local preachers recommended for Deacons' Orders. Aaron Robins, recommended from the Madison District, was elected. William V. Daniels, S. Bottosff, Shadrack B. A. Carter, and Facter Knox were recommended from Charlestown District and were elected. John Jones not elected.

Conference proceeded to the consideration of question 3rd on the minutes, and J. C. Smith, Ancil Beach, Isaac Kimble, Isaac N. Ellberry, A. F. Thompson, H.

4 The General Conference of 1816 passed a resolution making it the duty of the book committee at New York to decide what sum was to go to married Bishops for family expenses, Bishop Roberts elected Bishop at this conference, being the first married Bishop. This was done until 1836 when the rule was so changed as to make it the duty of the annual conference in which a bishop resides to estimate the amount of necessary expenses. From 1819 to 1832 Bishop Roherts received $\$ 200$ a year for family expenses, from 1832 to $1836, \$ 250$, and from 1836 to $1840, \$ 300$; from 1840 to his death, $\$ 400$ a year. Besides this he received a quarterage of $\$ 200$ yearly, which was contributed by all the Conferences. (Life of Roberts, by Rer. Charles Elliott, DD., p. 359.) 
S. Talbott, Amos Sparks, Jno. Ritchie, E. R. Ames having been previously examined by the committee appointed for that purpose were called forward and examined before the Conference by Bishop Soule as the Discipline directs ; afterward their characters were severally examined, and all admitted into full connection and elected to Deacons' Orders, except Brothers Sparks and Ellsbury, who were previously ordained when local preachers.

The case of William Taylor was called and some objections being made to his course as an itinerant minister, he was on motion discontinued. J. H. Hill and D. M. Murphy were discontinued.

Whereupon Conference adjourned.

Friday, 2 o'clock p. m. Conference met pursuant to adjournment, and was opened according to rule. The list was called, and Journals read and approved. Conference proceeded to business. Bishop Soule in the chair.

The case of Thomas Davis was called up and some charges being brought forward, on which a committee had previously passed, and he had been suspended. The charges were read and the plaintiff, L. B. A. Carter introduced his testimony and made some remarks, and Brother Davis being absent, a communication from him was read, also all the papers which the said Davis had forwarded were all read to the Conference. And after due deliberation, he was adjudged guilty of maladministration and falsehood, and on motion Thomas Davis was expelled from the Methodist Episcopal Church. Whereupon Conference adjourned.

The following resolution of the General Conference, being spread before the Conference by the President, was ordered to be journalized, viz: "Resolved, Second, That in making out the minutes of the Annual Conferences for publication, the above question shall be in- 
serted and fully and distinctly answered so as to show, 1st. Who are the superannuated preachers and widows and orphans of preachers, having claims on the Conference and the sum to which each one is entitled? 2nd. What preachers and on what circuits are deficient of their allowance, and the amount of each one's deficiency. 3d. What has been collected on the circuits and stations-naming, also, those, if any such there be, for which nothing shall have been received or contributed by benevolent Societies or individuals, or drawn from the Book Concern and Chartered fund to meet their claims.

Saturday, half-past eight o'clock a. m. Conference met pursuant to adjournment and was opened according to rule. The list was called and Journals read and approved. Conference proceeded to business, Bishop Soule in the chair. Conference resumed the consideration of the case of local preachers recommended for Deacon's Orders. John Evans and Amasa Johnson were recommended from Indianapolis District and elected.

Conference then proceeded to the consideration of the Local Deacons as recommended for Elder's Orders. Joseph Barrett was recommended from Indianapolis District, was elected. The committee appointed on the subject of the Conference Seminary presented their report, which was read and adopted.

The report: "Next to the religion of the Son of God your committee consider the light of science calculated to lessen the sum of human woe and to increase the sum of human happiness. Therefore we are of the opinion that the means of education ought to be placed within the reach of every community in general, so that all may have an opportunity of obtaining an ordinary and necessary education. From observation and information your committee are well convinced that 
where superior schools and colleges are neglected, ordinary schools are almost universally in a languished state. And many persons are reared, and live and die without any education. We therefore think that Seminaries and Colleges under good literary and moral regulations are of incalculable benefit to our country, and that a good Conference Seminary would be of great and growing utility to our people. We are aware that when a Conference Seminary is named, some of our preachers and many of our people suppose we are about to establish a manufactory in which preachers are to be made. But nothing is farther from our views, for we are fully of Mr. Bernge's opinion who, when comparing ministers to pens, observes 'that although the Seminaries have been trying to make pens for some hundreds of years, they will not write well till God nibs them." "

When we examine the state of the literary institutions of our country we find a majority of them are in the hands of other denominations (whether rightfully or otherwise, we do not take it upon ourselves to determine) whose doctrine in many respects we consider incompatible with the doctrines of revelation, so that our people are unwilling (and we think properly so) to send their sons to those institutions. Therefore we think it very desirable to have an institution under our own control from which we can exclude all doctrines which we deem dangerous; though at the same time we do not wish to make it so sectarian as to exclude or in the smallest degree repel the sons of our fellow citizens from the same.

To accomplish the foregoing desirable objects we most earnestly recommend the Conference the use of the means that will lead to the end. We would advise that the Presiding Elders of the several districts be required to collect all the information in their power in reference to an eligible site, and the means to build, 
and present the same to the next Conference. All of which is respectfully submitted.
C. W. RUTER,
A. WILEY,
JAMES ARMSTRONG. ${ }^{5}$

On motion the Conference proceeded to elect five members as a Missionary committee. A. Wiley, James Armstrong, James L. Thompson, James Havens and George Locke, the said committee.

A resolution of the late General Conference on the subject of the claims of the Canada Conference on the property invested in the Book Concern was by the President laid before this Conference, which was as follows: Resolved, That if three-fourths of the members of the several annual Conferences who shall be present and vote on the subject, shall concur herein, and as soon as the fact of such concurrence be certified by the Secretaries of the several Annual Conferences, the Book Agents and the Book Committee in New York shall be, and they are hereby authorized and directed to settle with the Agents of the Canada Conference on the following principles, preliminaries, etc. Wherefore the following resolution was offered, to wit: Resolved by the members of the Indiana Conference now in session, that we concur in the resolution of the late General Conference which authorizes the Book Agents of New York to divide the stock of the Book Concern of the Methodist Episcopal Church with the Canada Conference, according to the terms proposed in the said resolution of the late General Conference.

After some discussion a motion was made that a further consideration of the subject be laid over until the next session of this Conference, which motion was lost. The ayes and noes being called for on the original

5 The adoption of this report was the first step taken looking toward the organization of Indiana Asbury University (DePauw University). 
question the vote was taken accordingly, and thirtysix members being present and all voting on the question unanimously voted in the negative.

The superintendent laid before the Conference a resolution of the late General Conference on the subject of altering the restrictive rules of our Church as to change the ratio of delation to the General Conference, which resolution was as follows: Resolved, That the General Conference recommend to the several Annual Conferences for their concurrence and adoption as provided in the sixth article of the restrictive rules, the following resolution, to amend the second article of the restrictive rules, etc. Whereupon the following resolution was offered:

Resolved, By the Indiana Annual Conference in session, that we concur in the resolution of the late General Conference relative to altering the restrictive rules of our Church on the subject of the ratio of delegation to the General Conference, and the yeas and nays being called for it was found that there were thirty-three members present who unanimously voted in the affirmative.

Conference then proceeded to fix on the place of its next session, and on counting the votes it was found that Madison, Jefferson County, Indiana, had a majority, and was accordingly announced as the place for the next session of this conference, which will meet on the 16th of October, 1833.

On motion, Resolved, That when the Conference meet in the afternoon the members proceed to form themselves into a Missionary Society auxilliary to the Missionary Society of the Methodist Episcopal Church.

On motion, Resolved, That each member of this Conference be requested to furnish a brief account at the next session, of his birth, early impressions, conversion, call to the ministry, etc., to be kept on the file with other Conference papers. On motion, the vote by 
which Bro. Scott was placed in a supernumerary relation, was reconsidered, and changed to a superannuated relation. Whereupon Conference adjourned.

Saturday, 2 o'clock p. m. Conference met pursuant to adjournment and was opened according to rule; journals read and approved; Conference proceeded to business. Bishop Soule in the chair.

According to a resolution in the morning session the members of the Conference proceeded to form themselves into a Missionary Society. After which Conference resumed its business. The President presented the case of Bro. James Ward as wishing to be transferred from the Kentucky to this Conference, and after due deliberation it was resolved that it is inexpedient for the President to transfer Brother Ward to this Conference.

The case of Brother Benjamin Edge was by the President laid before the Conference as wishing to transfer from Virginia to this Conference, and after due deliberation it was resolved on motion that it was inexpedient for the Superintendent to transfer Bro. Benjamin Edge to this Conference.

On motion it was resolved that Bro. Isaac N. Elsbury be elected to Elder's Orders. Whereupon Conference adjourned.

Monday, at one-half past eight o'clock a. m. Conference met pursuant to adjournment and was opened according to rule, Journals read and approved; the list was called. Conference proceeded to business. Bishop Soule in the chair.

The committee appointed to estimate the amount necessary to support the several missions in the bounds of the Indiana Annual Conference presented their report which was as follows:

To the Superintendent of Missions To the Missionary on upper Wabash_._._._. 100.00 
To the Missionary at Fort Wayne

To the Missionaries at St. Joseph and South

Bend

To the Missionary at Kalamazoo

75.00

Sum total

$\$ 500.00$

The Committee on Missions presented their report, which was read and adopted. On motion, resolved, that each and every missionary within the bounds of this Conference shall make collections on his field of labor, and keep accurate accounts of monies received and expended by him, and also render an account of the time actually employed by him in his mission and report the same to the next Annual Conference.

On motion the Conference proceeded to elect a Vice-President of the Missionary Society (parent) of the Methodist Episcopal Church at New York and on counting the votes Allen Wiley was found to have the highest vote and was declared duly elected.

The Book Committee presented their report which was read; whereupon Conference adjourned for one hour. At eleven o'clock Conference met pursuant to adjournment. The Book Committee having their report read again to the Conference which was on motion adopted.

On motion a collection was taken up in the Conference room for the aid of Bro. John Strange. On motion, Resolved that each Presiding Elder present to the people of his charges a subscription for the purpose to aid Bro. John Strange in procuring a place of residence and make their return to the preacher who may be stationed in Indianapolis. ${ }^{6}$

On motion, Resolved, That the vote of thanks of this Conference be given to the citizens of New Albany

6 This collection probably resulted in the purchase of a house and lot for John strunge in Indianapolis. He died December 2, 1832 . 
for their kind attention to the preachers, and also to the Presbyterian Church for the use of their meeting house during the session of this Conference, and also to the members of the New Albany Lyceum for the use of their room for the sitting of Conference.

The Journals were read and approved. An address was delivered to the Conference by Bishop Soule, after which Conference united in singing and prayer; the appointments were then read, whereupon Conference adjourned.

\section{W. RUTER, Secretary.}

JOSHUA SOULE.

A COURSE OF STUDY FOR THE CANDIDATES ENTERING THE MINISTRY OF THE M. E. CHURCH.

A course of study recommended to the candidates for the ministry in the M. E. Church. The Holy Ghost saith, "Study to show thyself approved unto God, a workman that needeth not to be ashamed, rightly dividing the Word of Truth." "Give attention to reading to exhortation, to doctrine."

It is therefore recommended to candidates for the ministry to study and make themselves acquainted with the following important points of doctrine: The general depravity of human nature; Redemption by Christ; repentence toward God; justification by Faith ; the direct witness of the Holy Spirit; holiness of heart and life, including regeneration and sanctification; the divinity of our Lord Jesus Christ; perseverance of those who have been justified; Baptism; resurrection of the dead; and future reward and punishment. Further recommended to study the principles of Church government, especially our own; the philosophy of English grammar, geography, Ancient History, Ecclesiastical History, Moral and Natural Philosophy, Logic. To aid the students in the acquisition of these important branches of knowledge the reading of the 
following books or as many of them as can be obtained is recommended: The Holy Bible, Wesley's Notes, Benson's, Clark's or Coke's Commentary, Wesley's Sermons and Answer to Taylor, Saint's Rest, Baxter's Serious Call, Benson's Sermons, Fletcher's Checks and Appeal, Portrait of St. Paul, Watson's Theological Institutes, Wood's or Martindale's Dictionary, Methodist Discipline, Murray's Grammar, Morse's Geography, Rollin's Ancient History, Mosheim's Ecclesiastical History, Reid's Philosophy, Paley's Natural Theology and Evidences, Wesley's Philosophy, Duncan's or Watt's Logic, and the Methodist Magazine.

(Signed) R. R. ROBERTS, JOSHUE SOULE.

New Albany, October 22, 1832.

APPOINTMENTS OF THE INDIANA CONFERENCE, 1832.

Madison District.

James Havens, Presiding Elder.

Madison-To be supplied.

Vevay_John Kerns, William M. Dailey.

Lawrenceburg-Joseph Oglesby, John C. Smith.

Whitewater-Joseph Tarkington, Hiram Greggs.

Wayne-Ancil Beach, David Stiver.

Newcastle-Nathan Fairchild, Cornelius Swank.

Connersville-John W. McReynolds, Robert Johnson.

Greensburg-To be supplied.

Mississinnewa-To be supplied.

Charlestown District.

William Shanks, Presiding Elder.

Charlestown-John Miller, Zacariah Games.

New Albany and Jeffersonvilie-Thomas S. Hitt, Edward R. Ames.

Corydon-George Locke, John Hasty. 
Paoli-Henry S. Talbott.

Bedford-Daniel Anderson.

Lexington-John Daniel.

Brownstown-Amos Sparks.

Washington-Hakaliah Vredenburgh.

\section{Indianapolis District.}

Allen Wiley, Presiding Elder. Indianapolis-Calvin W. Ruter.

Fall Creek-Isaac N. Ellsbury.

White Lick-Thomas J. Brown.

Vernon-To be supplied.

Columbus-Charles Bonner.

Rushville-Spencer W. Hunter, Isaac Kimball.

Franklin-Asa Beck, Elijah Whitten.

Bloomington-Samuel R. Brenton.

Greencastle-Eli P. Farmer, Henry Deputy.

\section{Vincennes District.}

James L. Thompson, Presiding Elder.

Rockville-Joseph White, Enoch Wood.

Terre Haute-Anthony F. Thompson, John Richey.

Carlisle-William H. Smith.

Vincennes-James Scott.

Petersburg-Samuel Julian.

Princeton-Enoch G. Wood.

Boonville-Miles Huffaker.

Lafayette-Richard Hargrave, Nehemiah B. Griffith.

Frankfort-_Stephen R. Ball.

Crawfordsville-Lorenzo D. Smith.

Pine Creek-Amasa Johnson.

Missionary District.

James Armstrong, Superintendent.

Upper Wabash Mission-Samuel C. Cooper. 
St. Joseph and South Bend Missions-Richard S. Robinson, George M. Beswick.

Kalamazoo Mission-James T. Robe.

Ft. Wayne Mission-James Armstrong.

Michael S. Taylor and James Hadley transferred to the Illinois Conference.

Alfred W. Arrington transferred to the Missouri Conference.

SECOND SESSION OF THE INDIANA CONFERENCE, HELD IN MADISON, OCTOBER, 1833.

Journal of the second Indiana Annual Conference, held in Madison, Jefferson County, Indiana, commencing on the 16th of October, A. D. 1833.

Wednesday morning, 9 o'clock, Conference met according to appointment, and was opened by Bishop Soule by reading a portion of the Holy Scriptures, singing and prayer. The list was called and the following persons being present took their seats, viz.: James Havens, Joseph Tarkington, William Shanks, John T. Johnson, Hakaliah Vredenburgh, Allen Wiley, C. W. Ruter, Isaac N. Elsbury, Thomas I. Brown, James L. Thompson, William H. Smith, Ancil Beach, John Ritchie, Joseph Oglesby, Henry S. Talbott, Richard Hargrave, N. B. Griffith, James Armstrong, Robert Burns, Amos Sparks, Richard S. Robinson, Samuel Branton, Boyd Phelps, Miles Huffaker, Asa Beck, Charles Bonner, Isaac Kimble, Edward R. Ames.

Conference proceeded to business. Bishop Soule in the chair. C. W. Ruter was nominated and elected Secretary. Conference proceeded to fix the time of meeting and adjournment; it was voted to meet at 8 o'clock a. m., and adjourn at 11 and meet at 2 o'clock p. m. and adjourn at 6 .

The by-laws of the preceding session were read and adopted for the present session. Brothers James Havens, Allen Wiley and W. M. Daily were nominated 
and elected a committee to appoint the preachers to officiate and to superintend the congregations during Conference.

Conference then proceeded to elect three Stewards to attend to the pecuniary matters of the Conference. William Shanks, Allen Wiley and James Armstrong were found to be duly elected to that committee. Conference proceeded to elect a committee to write the memoirs of the dead. A. Wiley, C. W. Ruter and James L. Thompson were found duly elected.

On motion Brothers J. Armstrong, Allen Wiley and N. B. Grifith were appointed a committee to take into consideration the propriety of forming a Preacher's Aid Society within the bounds of this Conference to report as soon as possible. The President appointed A. Wiley, C. W. Ruter, James Havens, Thomas C. Hitt and N. B. Griffith a committee to examine the candidates for admission into full connection.

Conference proceeded to the consideration of the first question on the minutes, viz.: Who are admitted on trial? The case of Eli Rogers was brought forward, but he was not admitted. The Presiding Elder has liberty to employ him when necessary. Whereupon the Conference adjourned.

Wednesday, 2 o'clock p. m. Conference met pursuant to adjournment. The list was called, the journal read and approved. Conference then proceeded to business, Bishop Soule in the chair.

Conference resumed the consideration of the first question on the minutes, and Edward Smith, William Campbell, William D. Watson, Jesse Harbin, William Clarke and Thomas Ray recommended from Vincennes District; John W. Sullivan, John Robbins, recommended from Madison District, all were admitted Sherwood P. Moore and Daniel Watkins were not admitted, but the Presiding Elder has leave to employ them if thought proper. John A. Brouse, John W. 
Holland, James Harrison, Samuel M. Reeve, Freeman Farnsworth and John Newell recommended from Indianapolis District, were admitted; Richard C. Meek, recommended from Madison District, was admitted, but John Crouch was not admitted.

Conference proceeded to the consideration of the second question on the minutes, viz.: Who remain on trial? And the characters of John Daniel, Henry Deputy, David Stiver, Elijah Whitton, Stephen R. Ball, Joseph White, Enoch Wood, Amasa Johnson, Hiram Griggs and Zechariah Games were severally examined and continued on trial. John Hasty was discontinued. Whereupon Conference adjourned.

Thursday, 8 o'clock a. m. Conference met pursuant to adjournment, and was opened according to rule. The list was called, journal read and approved. Conference proceeded to business, Bishop Soule in the chair.

James Armstrong, James Havens and Allen Wiley were nominated and elected a committee to estimate the table expenses this year of Bishop Roberts. N. B. Griffith, Samuel C. Cooper, William Shanks, James Armstrong and Thomas I. Brown were elected a Missionary Committee, according to the provisions of the Discipline.

Conference proceeded to the examination of the character of the Deacons of one year's standing, and the characters of John C. Smith, Ancil Beach, Isaac Kimble, Henry S. Talbott, John Ritchie, E. R. Ames, and Spencer W. Hunter were severally examined, approved and passed. The case of Brother Anthony S. Thompson was called when it was announced that after laboring faithfully and usefully during the first quarter of the past year he sank under affliction and finally died in great peace. Conference then proceeded to the consideration of the third question on the minutes, viz.: Who are admitted into full connection? George 
M. Beswick, Nathan Fairchild, William M. Daily, James T. Robe and Cornelius Swank, having been previously examined by the committee on education, were called forward, examined and admonished before the Conference by Bishop Soule as the Discipline directs, after which their characters were severally examined, approved and admitted, and they were elected to Deacon's Orders, except Brother Fairchild, who was not admitted. Whereupon Conference adjourned.

Thursday, 2 o'clock p. m. Conference met pursuant to adjournment and was opened according to rule. The list was called, Journal read and approved, and proceeded to business, Bishop Soule in the chair. The Stewards spent some time in attending to the pecuniary affairs of the Conference.

The President presented a communication from the Agents of the New York, containing an exhibit of the Book Concern of the Methodist Episcopal Church. Also a communication from the same agents relative to the propriety of establishing a paper in Cincinnati, Ohio, to bear the same relation to the Church as the Christian Advocate and Journal, and on motion the said communications were referred to a committee of five, C. W. Ruter, E. R. Ames, James Armstrong, Allen Wiley, and William Shanks.

A communication was received and read from the Ohio Conference on the same subject, which on motion was referred to the same committee.

Conference took up the case of Robert Johnson and after due consideration he was discontinued. The case of Philip May was taken up and recommended for admission into the traveling connection, was admitted. On motion resolved that the Presiding Elder have leave to employ N. Fairchild. Conference proceeded to the consideration of the characters of the candidates for Elder's Orders. Samuel Brinton, R. S. Robinson, 
and Boyd Phelps were examined. Brothers Phelps and Robinson were elected. Conference adjourned.

Friday, 8 o'clock a. m. Conference met pursuant to adjournment and was opened according to rule and proceeded to business, Bishop Soule in the chair. The committee appointed to estimate the table expenses of Bishop Roberts for the ensuing year reported the amount to be $\$ 250$. On motion E. R. Ames, Joseph Oglesby and Ancil Beach were appointed a committee to inquire into the manner in which the preachers of this conference have discharged their duty during the past year as it relates to the subjects of Sabbath Schools, Tracts and Bible Societies and report as soon as practicable.

Conference resumed the consideration of characters of those eligible to Elder's Orders. The characters of Miles Huffaker, Asa Beck, Charles Bonner, Lorenzo D. Smith, were severally examined and elected. Conference proceeded to the examination of local preachers presented for Deacon's Orders. Alfred S. Cotton and David Stiver, recommended from Madison District; C. Garner, from Charlestown District; Daniel Watkins, Joseph Wheeler, Samuel A. Steward, Thomas Ray, from Vincennes District; Timothy Hunt and Stephen Masters, recommended from Indianapolis District, were elected. John McEwin and John K. Davison were not elected.

Conference proceeded to the consideration of the examination of the characters of local Deacons, recommended for Elder's Orders. Thomas McCool and Amos B. Cobb were recommended from Kalamazoo Mission District and elected to that office. Conference proceeded to the examination of the characters of Elders James Havens, John Kern, Joseph Oglesby, Joseph Tarkington, John W. McReynolds, William Shanks, John Miller, Thomas I. Hitt, George Lock, Daniel Anderson, John T. Johnson, Hackaliah Vredenburgh, A. 
Wiley, C. W. Ruter, Isaac N. Elsberry, Thomas J. Brown, Eli P. Farmer, James L. Thompson, William H. Smith, were severally examined, approved and passed. Brothers Hitt, Lock and Anderson received a superannuated relation, and Brother Farmer received a location at his own request. The case of James Scott was called and a motion was made that he receive a location, but before the question was taken the Conference adjourned.

Friday, 2 o'clock p. m. Conference met pursuant to adjournment and was opened according to rule. Conference proceeded to business, Bishop Soule in the chair. Resumed the consideration of the characters of Elders and the case of Brother Scott being called up, on motion, received a location.

The character of Richard Hargrave, N. B. Griffith, Samuel Julian, Enoch G. Wood, James Armstrong, Samuel C. Cooler, Amos Sparks and Robert Burns were severally examined, approved and passed, and Brother Burns received a superannuated relation.

The name of Brother Strange was called when it was announced that he died in great peace on the $2 \mathrm{~d}$ of December last, and on motion resolved the committee of appointments be requested to select some one to preach next Sabbath on the death of Brothers Strange and Thompson.

The committee on Missionary affairs presented their report which was read and adopted. On motion resolved that the Presiding Elder in whose District Brother Johnson may reside, shall have leave to employ him if necessary the ensuing year. The agent appointed last year to inquire into the estate of the legacy left by James Paxton, deceased, for the benefit of the M. E. Church in Indiana, presented his report, which was read and on motion was adopted.

On motion C. W. Ruter and James L. Thompson were appointed agents to attend the next Illinois An- 
nual Canference to adjust the business relative to the legacy of Samuel Paxton, deceased, left by him for the benefit of the M. E. Church in Indiana, and ordered that so much of the will of James Paxton as relates to the said legacy be spread on the journal of this Conference, which is as follows, viz.: "I hereby give and bequeath to Calvin Fletcher, James Armstrong and James Given as trustees five hundred dollars for the use and benefit of the Illinois Annual Conference of the M. E. Church to be appropriated by said Conference to the best of their judgment in extending the work of the Lord in the bounds of the State of Indiana, helping the most needy preachers belonging to that Church either effective or superannuated, which amount is to be paid over by said trustees as soon as convenient."

A. Wiley was appointed agent by this Conference to attend to receiving the legacy left by Isaac Swearingin for the benefit of the M. E. Church in Indiana. On motion Conference adjourned.

Saturday, 8 o'clock a. m. Conference met pursuant to adjournment and (was) opened according to rule. The list was read and Journal (approved). Conference proceeded to business, Bishop Soule in the chair.

The committee appointed to collect information on the subjects of Sunday School Bible and Tract Societies, presented their report, which was read and adopted. And on motion the list was called and every preacher required to answer for himself in case of delinquency, which was done accordingly. On motion, resolved that when Conference adjourns, its present session not to meet again until Monday morning at the appointed hour.

On motion Brother A. Wiley was appointed to preach the funeral sermon of Brothers Strange and Thompson at 3 o'clock p. m. tomorrow. The commit- 
tee appointed to take into consideration the expediency of forming a Methodist Preacher's Aid Society presented their report, which was read and adopted, and Conference proceeded to elect James Armstrong, Allen Wiley, C. W. Ruter as a committee to prepare a Constitution for the above named Society and report to the next Annual Conference.

Joshua Law, a local preacher recommended from Indianapolis District for Deacon's Orders, was elected, being properly recommended, was admitted on trial, in the traveling connection, with the understanding that his children should not be claimants on this Conference. Samuel Brenton and Asa Beck, at their own request, received a location. The committee to whom was referred the communication from the Agents at New York relative to the establishment of a periodical in the West presented their report which was read and adopted unanimously. The report is as follows:

1st. Resolved, That in the opinion of this Conference the establishment of a weekly paper in the city of Cincinnati under the control of the Methodist Episcopal Church as is the Christian Advocate and Journal, is highly expedient, and that the interest of the Western Conferences require it.

2d. That the agents at New York and their proper advisors have the right and may authorize the agents and Book Committee at Cincinnati to establish such a paper in the interval of General Conference and appoint an editor for the same.

3d. That the establishment of such a paper would receive the united support of the Indiana Annual Conference as well as their entire approbation. All of which is respectfully submitted.

C. W. RUTER,

Chairman of the Committee.

1 "The Western Christian Adrocate" began publication in 1834, with Charles Elliott as the editor. From the first issue until the 
Conference proceeded to fix the place of holding their next session, and on counting the votes it was found that Centerville, Wayne County, Indiana, had the majority, and was announced as the place for the next session of this Conference to be held, which will be on the $22 \mathrm{~d}$ of October, 1834. Conference voted to draw on the book (Concern) room for four hundred dollars and on the chartered fund for seventy-five dollars. Whereupon Conference adjourned.

Monday, 8 o'clock a. m. Conference met pursuant to adjournment and was opened according to rule. The list was called and journal read and approved. Conference proceeded to business, Bishop Soule in the chair.

The Missionary Committee presented their report, fixing the amount necessary for the support of the Missions within the bounds of this Conference, which are as follows:

For Tippecanoe and Eel River Mission__-__-_\$ $\$ 75.00$

For Miscellaneous Mission____________-_ 75.00

For Maumee and St. Moriah Mission____-__-_ 75.00

For Kalamazoo Mission__._._._._._._._. 50.00

For the Superintendent of those_-_-_-_-_- 100.00

$\$ 275.00$

On motion the Conference reconsidered the vote by which they refused to receive Daniel Watkins on trial into the traveling connection, and after due deliberation he was admitted.

On motion Conference reconsidered the vote by which Robert Johnson was discontinued and after due consideration he was continued on trial. On motion C. W. Ruter was appointed a committee to attend, as

present it has maintained a high standard, and has been a great factor in the development of Methodism in the old Northwest. The library of DePauw University possesses the files of the Western, with only a few gaps, complete. 
far as possible, to a proper adjustment of the papers of Brother J. Strange, deceased, and to make a collection of any debts due him at the time of his death. A Constitution of a Bible, Tract and Sunday School Societies was read, and on motion was laid on the table. On motion Brothers Ames, Armstrong and Thompson were appointed a committee to take into consideration the expediency of forming this Conierence into a Missionary, Sunday School, Bible and Tract Society, auxiliary to the parent Society at New York.

The Committee on Memoirs presented their report which was read, containing a succinct account of the life and death of Brothers John Strange and Anthony Thompson deceased. Said report was adopted. Whereupon Conference adjourned.

Monday, 2 o'clock p. m. Conference met according to adjournment and opened according to rule. Bishop Soule in the chair. Conference proceeded to business. The Committee relative to the Bible, Tract and Sunday School Society presented their report which was adopted and the Conference proceeded to the formation of the society as directed by said report. A Constitution for Auxiliary Societies in the stations and Circuits within the bounds of this Conference was adopted. And on motion Brothers Boyd Phelps and John C. Smith were appointed to furnish each of the Presiding elders with a copy of the said Constitution.

Resolved, That we, the members of the Indiana Annual Conference, will uniform ourselves in roundbreasted coats and so appear at our next Annual Conference, should we be present.

\section{N. B. GRIFFITH, JAMES ARMSTRONG.}

Tuesday, 8 o'clock a. m. Conference met pursuant to adjournment and was opened according to rule. List was called and the journal read, and Conference proceeded to business, Bishop Soule in the chair. 
The Conference Stewards presented their report, which on motion was adopted.

Resolved, That the thanks of this Conference be presented to the Masonic Fraternity for the use of their hall during the sitting of this Conference.

Resolved, That the thanks of this Conference be presented to the citizens of this town for their hospitality to this Conference during their session among them.

Resolved, That the thanks of this Conference be presented to the several religious denominations of this town, who offered their houses of worship for occupancy on this occasion.

On motion, A. Wiley, James Armstrong, James Havens, James L. Thompson, William Shanks were appointed a committee to make inquiries relative to the establishment of a Conference Seminary.

The appointments were then read out, after which Conference adjourned its annual session.

JOSHUA SOULE.

C. W. RUTER, Secretary.

APPOINTMENTS IN THE INDIANA CONFERENCE FOR 1833.

\section{Madison District.}

Allen Wiley, Presiding Elder.

Madison Station-Lorenzo D. Smith.

Vevay-Richard S. Robinson, John W. Holland.

Lawrenceburg-William M. Daily, John Daniel.

Whitewater-Charles Bonner, John Robbins.

Wayne-John C. Smith, Isaac Kimball.

Newcastle-Robert Burns, sup., one to be supplied.

Connersville-John W. McReynolds, James Harrison.

Greensburg-Joseph Tarkington.

Vernon-Joshua W. Law, Robert Johnson. 


\section{Charlestown District.}

William Shanks, Presiding Elder.

New Albany-To be supplied.

Jeffersonville-Edward R. Ames.

Corydon-John Kerns, Elijah Whitten.

Salem-Zecariah Games.

Bedford-Hiram Greggs.

Brownstown-John T. Johnson.

Paoli--Henry S. Talbott, Jesse Harbin.

Lexington-Joseph Oglesby.

\section{Indianapolis District.}

James Havens, Presiding Elder.-

Indianapolis Station-Calvin Ruter.

Indianapolis Circuit_John W. Sullivan.

Fall Creek-Ancil Beach, Lemuel M. Reeves.

Danville-Joseph White.

Mooresville-Philip May.

Columbus-Spencer W. Hunter.

Rushville-Isaac N. Ellsbury, David Stiver.

Franklin-Amos Sparks.

Bloomington-William H. Smith.

\section{Vincennes District.}

James L. Thompson, Presiding Elder.

Carlisle_John Richey, James T. Robe.

Petersburg-Samuel Julian.

Princeton-Enoch G. Wood, Cornelius Swank.

Boonville-Thomas Ray.

Washington-Miles Huffaker.

Terre Haute-Richard Hargrave, William Watson.

Rockville-Samuel C. Cooper, Henry Deputy.

Greencastle-Thomas J. Brown.

Crawfordsville-John A. Brouse, Daniel Watkins.

Lafayette-Nehemiah B. Griffiths, Hakaliah Vredenburg. 


\section{Northwestern District.}

James Armstrong, Presiding Elder.

St. Joseph-John Newell, Edward Smith.

South Bend-Boyd Phelps.

Pine Creek-William Clark.

Carroll-Enoch Wood.

Frankfort-Stephen R. Ball, William Campbell.

Tippecanoe and Eel River Mission-Amasa Johnson.

Mississinaway Mission-Freeman Farnsworth.

Maumee Mission-To be supplied.

Kalamazoo Mission-Richard C. Meek.

THIRD SESSION INDIANA CONFERENCE, 1834.

Journal of the Third Indiana Annual Conference of the Methodist Episcopal Church held at Centerville, Wayne county, Indiana, commencing on the 22nd of October, A. D. 1834.

Wednesday morning, 9 o'clock, conference met according to appointment and opened by Bishop Roberts by reading a portion of the Sacred Scriptures, singing and prayer. The list of membership was called and the following members having answered to their names, took their seats, viz: Allen Wiley, R. L. Robinson, William M. Daily, Charles Bonner, John C. Smith, Isaac Kimball, Joseph Tarkington, William Shanks, John Miller, George M. Beswick, Edward R. Ames, John Kern, John T. Johnson, Henry L. Talbott, Samuel C. Cooper, Boyd Phelps, Joseph Oglesby, James Havens, Calvin W. Ruter, Ancil Beach, Spencer W. Hunter, Amos Sparks, William H. Smith, James L. Thompson, John Ritchie, James T. Robe, Enoch G. Wood, Cornelius Swank, Miles Huffaker, R. Hargrave, Thomas J. Brown, Charles M. Holiday.

Conference then proceeded to business, Bishop Roberts in the chair. C. W. Ruter was nominated and 
elected Secretary, and E. R. Ames Assistant Secretary. Conference proceeded to fix the time for meeting and adjournment as follows, to meet at 8 a. m. and adjourn at 11:30 a. m.; meet at $2 \mathrm{p}$. m. and adjourn at $4: 30$ p. m.

A. Wiley, J. C. Smith, Isaac Kimball were appointed a committee for the purpose of appointing the preachers to officiate and superintend the congregations during the present session of conference.

Conference proceeded to elect the Stewards; on counting the votes William Shanks, Allen Wiley and E. R. Ames were elected.

On motion a committee of three were appointed to write the memoirs of the dead; C. W. Ruter, B. Phelps and W. Shanks were appointed that committee.

On motion a committee of five were appointed to examine the candidates for admission into full connection; A. Wiley, C. W. Ruter, R. Burns, R. Hargrave and J. Havens were appointed that committee.

On motion a committee of three were appointed, viz: E. G. Wood, H. L. Talbott, S. C. Cooper to adjust the accounts with the Book Concern at New York.

Brother B. Phelps and C. W. Ruter were nominated to fill the vacancy in the missionary committee, occasioned by the death of James Armstrong and N. B. Griffith.

The by-laws of the former session of this conference were read and on motion, were adopted for the government of the present session.

Conference proceeded to the consideration of the first question on the minutes. Joseph Carter, Thomas Bartlett, F. C. Holliday, Sanford L. Williams, Daniel H. Dickerson, recommended from Madison district, were admitted on trial. Colbert Hall was not admitted, but on motion the Presiding Elder has leave to employ him when he deems it expedient. James Jones readmitted. William V. Daniel, Thomas Gum, John S. 
Bayless, Lewis Hurlbert, Steward P. Moore and D. Stucker were recommended from Charlestown district, and admitted on trial. Conference then adjourned.

Wednesday, 2 o'clock p. m., conference met pursuant to adjournment and was opened according to rule. Conference proceeded to business, Bishop Robberts in the chair.

The President received some communications from the Book Agents at New York containing an exhibit of the concern, etc., which was read and on motion referred to the book committee, and on motion, ordered that so much of it as concerns the fiscal condition of the concern be spread on the Journal of the conference.

Asa Beck and Aaron Wood were readmitted into this conference.

Conference resumed the consideration of the first question on the minutes. Isaac Owen and M. Reeder were recommended from Vincennes district and admitted on trial and James Ross was readmitted. Eli Rogers, recommended from Pine Creek circuit, was not admitted. Thomas $\mathrm{McCool}$ and Gilbert Rose were recommended from the Northwestern district but not admitted. On motion the Presiding Elder has liberty to employ them if he deems it necessary. John Robinson, recommended from the same district, was admitted.

On motion, the conference requested the Superintendent to transfer John Ray, ${ }^{1}$ a superannuated preacher, from the Kentucky conference to this at his own request, with the understanding that neither himself nor family should ever be claimants on this conference; which transfer was made accordingly.

Conference proceeded to the consideration of the second question on the minutes, viz: Who remain on trial? William Watson was, on motion, discontinued, at his own request, in consequence of affliction. J. W.

1 John Ray was an aged preacher, of Kentucky, who transferred to Indiana in order to be near his son, Thomas Ray. 
Sullivan discontinued at his own request. The characters of William Clark, J. A. Brouse, James S. Harrison, Freeman Farnsworth and R. C. Meek were severally examined and continued on trial. Joshua W. Law was discontinued. William Campbell, J. Harben, Thomas Ray, L. M. Reeves were examined and continued on trial. John Robbins and Daniel Watkins were discontinued at their own request, J. W. Holland and Philip May were also discontinued. Whereupon conference adjourned.

Thursday, 8 o'clock a. m., conference met pursuant to adjournment and was opened according to rule and proceeded to business. Bishop Roberts in the chair. Conference voted to draw on the chartered fund for $\$ 75.00$ and on the Book Concern for $\$ 600.00$.

On motion the vote was taken on yesterday by which John Robinson was admitted on trial was reconsidered, and he was permitted to withdraw his application. The case of Edward Smith next came before the conference and the President (read) a letter from a friend in Warren county, informing the conference that Brother Smith departed this life on the 9 th of October.

Conference then proceeded to the consideration of the third question on the minutes, viz: Who were admitted into full connection? Answer, I. Daniel, David Stiver, Joseph White, Enoch Wood, Elijah Whitten and Amasa Johnson, having been previously examined by the committee appointed for that purpose, were called up and examined before the conference as the discipline directs, after which their characters were examined and passed, and elected to Deacons' Orders, except Brothers Stiver and Johnson, who were previously ordained as local preachers. Zac. Games, S. R. Ball, Hiram Grigg were continued on trial at their own request. Robert Johnson and Henry Deputy were discontinued. Whereupon conference adjourned. 
Thursday, 2 o'clock p. m., conference met pursuant to adjournment and was opened according to rule. Conference proceeded to business, Bishop Roberts in the chair. Conference proceeded to the consideration of the third question on the minutes, viz: Who are Deacons? William M. Daily, George M. Beswick, T. Robe and Cornelius Swank, the characters of whom were severally examined and passed. The characters of John C. Smith, Issac Kimball, John Ritchie, S. W. Hunter, A. Beach, Henry Talbott and E. R. Ames were severally examined, approved and passed; also elected to Elders Orders. Isaac Kimball asked and obtained a location.

Conference proceeded to the examination of the characters of Elders. Allen Wiley, L. D. Smith, R. S. Robinson, C. Bonner, R. Burns, J. W. McReynolds, Joseph Tarkington, William Shanks, J. Miller, J. Kern, J. T. Johnson, J. Oglesby, J. Havens, C. W. Ruter, J. N. Ellsbury, A. Sparks, W. H. Smith, J. L. Thompson, Samuel Julian, E. G. Wood, Miles Huffaker, R. Hargrave, S. C. Cooper, T. J. Brown, H. Vredenburgh, B. Phelps, T. S. Hitt and D. Anderson were severally examined and approved. L. D. Smith, J. N. Sallsbury and T. S. Hitt each asked and received a location. The relation of R. Burns was changed from supernumerary to effectual. The names of Brothers G. Lock, N. B. Griffith and James Armstrong were called when it was announced that during the past year they finished their labors and died in peace. James Ray, by vote of conference, was continued in a supernumerary relation. Whereupon conference adjourned.

Friday, 8 o'clock a. m., conference met pursuant to adjournment and was opened according to rule. Journal read and approved, Bishop Roberts in the chair. Conference proceeded to business. On motion, conference reconsidered the vote that changed the hour of morning sitting and fixed the hour at 8:30 a. m. 
Conference proceeded to elect by ballot some person to preach the funeral of the said deceased brethren and Bishop Roberts was elected. Henry S. Talbott asked and obtained the supernumerary relation.

The vote by which $W$. Watson was discontinued was reconsidered and he was continued on trial. John Newel was discontinued at his own request.

The following resolution was presented and accepted, viz: Resolved, that this conference memorialize the Legislature of this state, praying that that honorable body, in their wisdom, to devise some measures by which the principal denominations of Christians in this state may have their due proportion of influence in the faculty of the State College at Bloomington and that a committee of three be appointed to draft a memorial and present it as soon as practical.

Resolved, second, That Presiding Elder and preacher in charge use their influence to have the people to petition the Legislature on the same subject, and that a committee of three be appointed to draft a form suitable for such a petition. ${ }^{2}$

$$
\text { (Signed) }
$$

C. W. RUTER. WILLIAM SHANKS.

2 Before any definite steps were taken to establish a Methodist college in Indiana, the Indiana Conference made an attempt to get the state Legislature to change the method of electing trustees for the state college at Bloomington. The Methodist objections to the state college as it then existerl were: (1) The institution was regarded as belonging to the Presbyterian church. It was listed in the catilogue of Presbyterian colleges. (2) The religious beliefs of Methodist students were not respected. (3) Efforts were made to convince the public that none but Presbyterians were competent to teach in higher institutions of learning, and (4) under the existing system no Methodist could be represented on the hoard of trustees, although the Methodists were the most numerous religions sect in the state. (F. C. Holliday "Life and Times of Allen Wiley," pp. 71-72.) Seren petitions were presented to the Indianil Legislature in 1,834, asking for "a reform in the economy of Indiana college." (House Journal, 1S34, pp. 82, 14s, 155. 22s, 236, 293, 368.) 
C. W. Ruter, William Shanks and Allen Wiley were appointed that committee.

Conference proceeded to the consideration of the case of local preachers recommended for Deacons Orders. Joseph Hutchens, Adam Bruner, G. W. Walker, Lewis Hurlbert and Jonathan Broady (a man of color), C. B. Jones, J. B. Dawson, Joseph Springer, Isaac Merrill and William M. Reyburn were duly elected to that office.

Conference proceeded to the consideration of the case of local deacons recommended for Elders Orders. Joseph Carter, Charles M. Morrow and Ebenezer Fairchild were duly elected to that office.

The committee appointed to write the memoirs of the dead presented their report containing the memoirs of Brothers Armstrong, Lock and Griffith, which were read and accepted.

The conference having requested the superintendent to decide whether the widow of Brother A. F. Thompson, deceased, be a legal claimant on the funds of this conference. He decided in the affirmative.

On motion, E. R. Ames was elected to fill the vacancy occasioned by the death of James Armstrong in the committee appointed at a former session of this conference to draught a Constitution for the Preacher's Aid Society.

Resolved, That in future the preachers in returning the numbers in society specify the number of local preachers, meeting houses and parsonages within the bounds of this conference.

Whereupon conference adjourned.

Friday, 2 o'clock p. m., conference met pursuant to adjournment and was opened according to rule, Journal read and approved, conference proceeded to business, Bishop Roberts in the chair. Conference proceeded to take the numbers of local preachers and the number of meeting houses. 
On motion, the conference reconsidered the vote by which James H. Ross was readmitted into this conference, and on taking the vote a second time he was not readmitted, but on motion the Presiding Elder has leave to employ him should he deem it necessary.

Conference proceeded to ascertain the most suitable place to hold its next annual session, and on counting the votes, it was decided to be held at Lafayette, Tippecanoe county, Indiana, to commence on the 14th of October, 1835.

Whereupon conference adjourned.

Saturday, 8:30 o'clock a. m., conference met pursuant to adjournment and was opened according to rule, Bishop Roberts in the chair, conference proceeded to business.

The committce appointed by conference at its last session to attend the Illinois conference for the purpose of adjusting the business relative to the bequest made by James Paxton, deceased, to said conference, made their report, which was accepted, and the preamble and resolutions of said conference were ordered to be spread on the Journal of this conference, which are as follows: "Whereas, James Paxton, late of the county of Marion and state of Indiana, deceased, did on the third day of April, A. D. 1829, by his last will and testament, among other things, make the following bequest, viz: I hereby give and bequest to Calvin W. Fletcher, Rev. James Armstrong and James Havens as Trustees, five hundred dollars for the use and benefit of the Illinois Annual Conference of the Methodist Episcopal Church, to be appropriated by the said conference to the best of their judgment in extending the work of the Lord in the bounds of the state of Indiana, helping the most needy preachers belonging to said Church, either effective or superannuated, which amount is to be paid over by the said Trustees as soon as convenient. And since that time the General Con- 
ference of the Methodist Episcopal Church held in Philadelphia on the 1st of May, 1832, the said Illinois Conference was divided and the state of Indiana including a small part of Michigan Territory, formed into a separate conference, denominated the Indiana conference of the Methodist Episcopal Church. Therefore, be it resolved, First, by the members of the Illinois annual conference in session assembled, that we do hereby request the said Indiana annual conference to receive and appropriate said bequest according to the best of their judgment in extending the work of the Lord in the bounds of the state of Indiana, by helping the most needy preachers, belonging to said conference, either effective or superannuated, according to the original design and intent of the testator. And we do hereby, the said Trustees, pay over the said amount of the bequest to the Indiana annual conference of the Methodist Episcopal Church. Resolved, that the foregoing preamble and resolutions be spread on the Journals of this conference; and that a copy hereof, signed by the President and countersigned by the Secretary, be forwarded to the said Indiana conference, to be by them spread on the Journals of their conference. Done at Mount Carmel, Illinois, October 3rd, 1834.

PETER AKERS,

S. H. THOMPSON,

Committee.

The above preamble and resolutions were adopted as the report of their committee and spread upon their Journal by the Illinois annual conference, during their session at Mount Carmel, Illinois, beginning on the 1st day of October, 1834.

(Signed) R. R. ROBERTS.

JOHN MITCHELL, Secretary.

Conference then proceeded to elect an agent to receive the money thus bequeathed to this conference, by 
James Paxton deceased, and on counting the votes, C. W. Ruter was declared duly elected. A request was presented from the Illinois annual conference that this conference pay the expenses of an agent sent by that conference to this, last fall and on a motion made that (the) request be granted, which motion was lost.

On motion, the book committee was requested to draw off the accounts in their hands that are unpaid and put them in the hands of the preachers who may be sent to those places where the debtors reside for colllection.

The committee appointed at the last session of the conference to draft a constitution for the Preacher's Aid Society, presented their report containing a form of a constitution which was read, amended and adopted. Conference voted that they proceed immediately on the adjournment of the present sitting to form such a society.

On motion, the conference adjourned until Monday at $8: 30$ o'clock.

Monday, 8:30 o'clock a. m., conference met pursuant to adjournment and was opened according to rule. Conference proceeded to business, Bishop Roberts in the chair. C. W. Ruter presented a draft of a constitution for auxiliary societies to the Preacher's Aid Society of the Indiana annual conference which was read, amended and adopted. And on motion, J. C. Smith was appointed a committee to procure the printing of 300 copies for the use of the preachers who belong to this conference. On motion, the vote by which I. Kimball was located, was reconsidered.

The Book Agent from Cincinnati presented a communication containing a report from the book committee, which was read.

On motion, Resolved, That for the ensuing year we will use increased exertions to promote the circulation of the Western Christian Advocate, and that a copy of 
this resolution be forwarded to the editor for publication.

The committee appointed to draft a memorial in behalf of this conference to the Legislature of this state relative to (the) State College at Bloomington, presented their report, which was read, and on motion, was adopted; which report read as follows:

To the Senate and House of Representatives of the General Assembly of the State of Indiana. Your memorialists represent to your honorable body, that they in common with their fellow citizens, recognize in the munificent grant of lands by the general government to our state (for the purpose of endowing a state institution of learning) a corresponding obligation on our part so to manage it as not to defeat the charitable bequest of our common country. We feel that cause of complaint exists in regard to this matter, yet we do not approach your honorable body as irritated and injured individuals asking for the redress of private wrongs, but as patrons and advocates of general science, pleading her cause and imploring you in your paternal character to open her prison doors. We would impress it upon your honorable body that the Literature belongs to no one denomination of persons, and that no one exclusively should be allowed to possess the keys that unlock her treasures. We apprehend that the funds of our state college were designed by their munificient donors to patronize science and advocate the cause of general literature and not of religious sects, and should it be divested from its original design (directly or indirectly) the donors are despoiled of a rich inheritance, and the legacy itself betrayed to a very questionable purpose. We feel a deep and abiding interest in the success of the institution, we recognize in the provision of its constitution, (and particularly 10th section) the generous confiding spirit in which its powers and functions were bestowed, as it 
were, in the absence of every uncharitable feeling or suspicion, that the hydra of sectarianism might erect its standard there, yet we in common with our fellow men of the state have to regret that our hopes in it have been disappointed. We look in its charter and read that the places of president, professors and tutors are open, soliciting capacity to occupy them without regard to religious professions or doctrines. We then turn our eyes on the faculty from the organization of the institution up to this hour, and we see one common hue, one common religion characterize every member, as if capacity and fitness were confined to one church and one set of religious opinions. We have heretofore borne this without complaint and would now be silent, had we no higher object than to contend for the places and honors of the institution. But when we see the youth of our own and other churches voluntarily abandoning and renouncing the institution because the religion of their fathers (is but tolerated) and not domiciled: then we feel impelled by every consideration that looks to the future, and speak out, and invoke you to reclaim for the state, the power bestowed upon the Board of Trustees of filling their own vacancies, and give to them a fixed and definite term of office in future. This wholesome restraint would, it is firmly believed, bring to the service of the institution a due proportion from other religious denominations, and breathe into it a new spirit, full of life and vigor. Your memorialists, therefore, earnestly solicit your interference in this matter, and that you may, in the premises do what is best for the good of science, is the earnest prayer of your memorialists."

The committee appointed to draft a petition suitable for the signatures of the citizens of this state, and send to the General Assembly, relative to the Bloomington College presented their report, which was read and adopted. On motion, J. A. Brouse, William 
M. Daily, B. Phelps, H. S. Talbott and J. S. Harrison were appointed a committee to furnish each preacher belonging to this conference with a copy of the same. Whereupon conference adjourned.

Monday, 2 o'clock p. m., conference met pursuant to adjournment and was opened according to rule, Bishop Roberts in the chair, conference proceeded to business. On motion, resolved, that the Secretary furnish the editors of the Indiana Journal and Democrat, with a copy of the memorial relative (to) the Indiana College, with a request that they publish it, and that they request the editors to publish the same. Conference proceeded to the consideration of the 16th question on the minutes, viz: What has been raised on the different circuits and stations for Bible, tract and Sunday school purposes?

Whereupon conference adjourned.

Tuesday, 8:30 o'clock a. m., conference met pursuant to adjournment and was opened according to rule. Conference proceeded to business, Bishop Roberts in the chair. On motion, the vote of this conference on yesterday in reference to the publication of the memorial by the editors of the Democrat was reconsidered, and the request withdrawn. On motion, the vote which made Eli Rogers a claimant on the funds of this conference was reconsidered, and the money appropriated to him by the stewards, was on motion, taken and put into the hands of the several Presiding Elders for the most necessitous cases.

On motion, the conference appointed the first Friday in December, as a day of fasting and prayer within the bounds of this conference.

On motion, Resolved, That this conference will patronize any seminary of learning which may be established within the bounds thereof, if desired, by appointing a teacher if practicable, and if not, by endeavouring to procure therefor a suitable teacher. 
Resolved, second, That each preacher in this conference shall use his influence in trying to encourage the cause of common school education, and endeavor to procure suitable teachers for such schools when practicable.

The stewards of conference presented their report which was read, and amended and adopted; and on motion, the amount which had been appropriated to J. N. Ellsbury, together with a small balance remaining in the hands of the stewards, be paid into the treasury of the Preacher's Aid Society of the Indiana annual conference.

Resolved, That the thanks of this conference be presented to the citizens of this place for having kindly entertained the members of the conference during the present session; also to the Trustees of the County Seminary for the use of the building. On motion, the conference adjourned to meet at the Methodist Episcopal Church at 3 o'clock p. m.

Tuesday, 3 o'clock p. m., conference met pursuant to adjournment, and was opened according to rule; conference proceeded to business, Bishop Roberts in the chair.

The missionary committee presented their report appropriating the amount necessary for the support of the missions within the bounds of this conference, which are as follows:

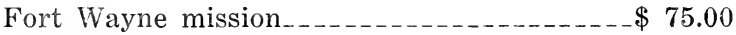

Kalamazoo mission _._._._._._._._._. 75.00

The superintendent of said missions _._._._. 100.00

Otter Creek mission _._._._._._._._._. 150.00

Troy mission _._._._._._._._._._._. 50.00

Superintendent of said missions_________- 30.00

Logansport mission _._._._._._._._._._. 50.00

Superintendent said mission__._.______. 15.00

Which report was read and adopted. On motion, 
resolved, that the appointments of the preachers for the ensuing year be read, which after singing and prayer was accordingly done. Whereupon conference adjourned to meet at Lafayette, Indiana, October 13, 1835.

R. R. ROBERTS.

C. W. RUTER, Secretary.

APPOINTMENTS OF THE INDIANA CONFERENCE FOR 1834.

Madison District.

Allen Wiley, Presiding Elder.

Madison-Enoch G. Wood.

Vevay-J. Jones, one to be supplied.

Lawrenceburg-Station, J. Daniel.

Lawrenceburg-Circuit, C. M. Holliday, one to be supplied.

Whitewater-J. W. McReynolds, J. S. Harrison.

Greensburg-W. M. Dailey.

Versailles-S. S. Williams.

Vernon-T. Gunn.

Charlestown District.

William Shanks, Presiding Elder.

Charlestown-Circuit, Joseph Tarkington, one to be supplied.

New Albany-Station, C. W. Ruter.

Jeffersonville-Station, W. V. Daniel.

Corydon-Circuit, J. Kern, J. Harbin.

Greenville-E. Whitten.

Salem-J. Miller, J. S. Bayless.

Paoli-D. Stucker, H. S. Talbott, sup.

Lexington-G. M. Beswick.

Indianapolis District.

J. Havens, Presiding Elder.

Indianapolis-Station, E. R. Ames.

Indianapolis-Circuit, H. Griggs. 
Rushville-Circuit, J. Carter, one to be supplied. Connersville-Robert Burns, L. M. Reeve.

Wayne-C. Bonner, F. C. Holliday.

Winchester-D. H. Dickerson.

Newcastle-Isaac Kimball.

Pendleton-S. W. Hunter.

\section{Bloomington District.}

J. Oglesby, Presiding Elder.

Bloomington-Station, J. C. Smith.

Bedford-J. T. Johnson.

Brownstown-L. Hurlbert.

Columbus-W. H. Smith.

Franklin-A. Beach.

Mooresville-A. Sparks.

Danville-A. Beck.

Greencastle-T. J. Brown, one to be supplied.

\section{Vincennes District.}

A. Wood, Presiding Elder.

Vincennes-Station, Z. Games.

Princeton-Circuit, J. A. Brouse, M. Reeder.

Boonville-T. Ray.

Troy Mission-E. Wood.

Washington-S. Julian.

Otter Creek Mission-I. Owen.

Terre Haute-J. White, D. Stiver.

Carlile-S. P. Moore.

Crawfordsville District.

J. L. Thompson, Presiding Elder.

Crawfordsville-Circuit, A. Johnson.

Rockville-S. C. Cooper, W. Campbell.

Covington-J. Ritchie.

Lafayette-W. Clarke, W. Watson.

Frankfort-B. Phelps, one to be supplied. 
Carroll-T. Bartlett.

Logansport Mission-M. Huffaker.

Pine Creek-H. Vredenburg.

\section{Laporte District.}

R. Hargrave, Presiding Elder.

South Bend-Circuit, S. R. Ball.

St. Joseph-R. S. Robinson.

Cassapolis-R. C. Meek.

Kalamazoo Mission-J. T. Robe.

Ft. Wayne Mission-F. Farnsworth.

Marion-Circuit, C. Swank.

FOURTH SESSION INDIANA CONFERENCE, LAFAYETTE, 1835.

JOURNAL of the Fourth Indiana Annual Conference of the Methodist Church, held at Lafayette, Tippecanoe county, Indiana, commencing October 14, 1835.

Monday morning at 9 o'clock conference met pursuant to adjournment and was opened by Bishop Roberts by reading a portion of the sacred Scriptures, singing and prayer. The list was called and the following members answered to their names:

A. Wiley, Charles Bonner, Enoch G. Wood, Joseph Oglesby, John Daniel, John C. Smith, Charles M. Holliday, Ancil Beach, William M. Dailey, Asa Beck, William Shanks, Aaron Wood, Joseph Tarkington, Joseph White, Calvin W. Ruter, James L. Thompson, John Kern, Amasa Johnson, John Miller, Samuel C. Cooper, Henry L. Talbott, Miles Huffaker, George M. Beswick, Hakaliah Vredenburg, James Havens, Richard Hargrave, E. R. Ames, Richard S. Robinson, James T. Robe, John Ray, Rodman Lewis, Thomas I. Brown.

C. W. Ruter was nominated and elected secretary and E. R. Ames, assistant secretary. Conference proceeded to establish the hour of meeting and adjournment, which were as follows: Meet at 8 o'clock a. m. 
and adjourn at $11: 30$; meet again at $2 \mathrm{p}$. m. and adjourn at $4 \mathrm{p} . \mathrm{m}$.

Bros. James L. Thompson, H. Vedrenburgh and William M. Clark were elected a committee to appoint the preachers to officiate during the conference; also to superintend the congregations. Conference then proceeded to elect three stewards to attend to the pecuniary concerns of the conference and in counting the votes, Allen Wiley, E. R. Ames and Samuel C. Cooper were declared duly elected. Bro. Rodman Lewis, an elder from New York conference, presented a certificate of his transfer to this conference and took his seat as a member.

The by-laws of the first session of this conference were, on motion, adopted for the government of the conference during this session. On motion, resolved, that a committee of three be appointed to attend to the books and periodicals, H. S. Talbott, I. C. Smith and William M. Dailey were appointed by the president as that committee. Conference proceeded to the consideration of the first question on the minutes, viz: Who are admitted on trial? Ebenezer Patrick, Isaac McElray, George C. Kunley were recommended from Charleston district and admitted, whereupon conference adjourned.

Wednesday at 2 o'clock p. m. conference met pursuant to adjournment and was opened according to rule. Bishop Roberts in the chair, proceeded to business. Conference resumed the consideration of the first question on the minutes and John W. Sullivan, recommended from Charleston district, was admitted. H. I. Durbin, Colbert Hall and Jacob M. Stoddard were recommended from Madison district and admitted. Charles W. Appleton and C. B. Jones, recommended from Indianapolis district, were admitted, but Charles M. Morrow, from the same district, was not admitted, but on motion, the Presiding Elder has leave 
to employ him should he deem it necessary. The book agent from Cincinnati presented a communication setting forth the condition of that branch of the concern, which wa sread. Conference resumed the consideration of the first question and Benjamin Griffith, recommended from Bloomington district, was admitted. William Hibben, George Tevebaugh and Warren Duncan, recommended from Vincennes district, were admitted. Israel L. Lewis and Eli Rogers, recommended from Crawfordsville district, were admitted. Conference adjourned.

Thursday, 8 o'clock a. m., conference met pursuant to adjournment and was opened according to rule and proceeded to business. Bishop Roberts in the chair. On motion, L. C. Cooper and Boyd Phelps were added to the committee appointed to superintend the congregations. On motion, the hour for conference to meet at 8 o'clock was changed to $8: 30$ a. m. Conference resumed the first question on the minutes and Daniel Demott, Elijah Sewall, William S. Mederis and E. Vanschoiack, recommended from Crawfordsville district, were admitted. Erastus Kellogg, Joseph Wolf, Thomas P. McCool and Stephen Jones were recommended from Laporte district and admitted and James V. Watson, Lorenzo D. Smith and George K. Hester were readmitted. Samuel R. Brinton was not readmitted. On motion, resolved that no preacher employed by the Presiding Elder be considered a claimant on the funds of this conference; whereupon conference adjourned.

Thursday, 2 o'clock p. m., conference met pursuant to adjournment and was opened according to rule and proceeded to business; Bishop Roberts in the chair. The stewards spent sometime in attending to the pecuniary concerns of the conference. Voted to draw on the chartered fund for ninety-one dollars, and on the book concern for eight hundred dollars. Conference 
proceeded to the consideration of the second question on the minutes, viz: Who remain on trial? The characters of T. C. Holliday, Daniel H. Dickerson, Thomas Quinn, William C. Daniel, Thomas Bartlett, Seward P. Moore, Isaac Owen, Sanford S. Williams, John S. Bayless, David Stucker, M. Reeder and Lewis Hulbert, each were examined and continued on trial. Conference adjourned.

Friday, 8 o'clock a. m., conference met pursuant to adjournment and was opened according to rule. Conference proceeded to business, Bishop Roberts in the chair. On motion, five were appointed to be denominated the committee on education. Allen Wiley, William Shanks, C. W. Ruter, Rodman Lewis and E. R. Ames were appointed that committee. A communication was received from the book agent at New York, which was read and filed among the conference papers. Conference proceeded to the consideration of the third question on the minutes, viz: Who were admitted into full connection? William Watson, John A. Brouse, Thomas Ray, Stephen R. Ball, Hiram Griggs, James S. Harrison, Lemuel L. Reeves, Isaac Games and William M. Clark, Richard C. Meek and Jesse Harbin having been previously examined by the committee on education, were called forward and questioned by the bishop and admonished as the discipline directs preparatory to their being admitted into full connection; after which their characters were severally examined and they were admitted and elected to Deacons Orders, except Bros. Clark, Ray and Games and Bros. Clark and Games were elected to Elders Orders. Bros. Freeman, Farnsworth and William Campbell were discontinued at their own request and Bro. Clark asked and obtained a location.

Conference proceeded to the consideration of the fourth question on the minuetes, viz: Who are Deacons? John Daniel, Amasa Johnson, Joseph White, 
David Stiver, Elijah Whitten and Enoch Wood and their characters were severally examined, approved and passed, and Bros. Johnson and Stiver elected to Elders Orders. Conference proceeded to the consideration of the fifth question on the minutes, viz: Who have been elected and ordained Elders? Wm. M. Dailey, George M. Beswick, James T. Robe and Cornelius Swank characters were severally examined and elected to Elders Orders. On motion, resolved that the members of this conference observe tomorrow as a day of fasting and humiliation and prayer. Conference adjourned.

Friday, 2 o'clock p. m., conference met pursuant to adjournment and was opened according to rule; conference proceeded to business, Bishop Roberts in the chair. Conference proceeded to the consideration of the case of the local preachers recommended for Deacons Orders. Stephen Liddle, Thomas Harget, William Northcott, John P. Edwards, Thomas Baker, Hanes Bartlett, Frances M. Richmond, Philip May and John Youngblood were duly elected to that office. Conference proceeded to the consideration of the case of the local deacons recommended for Elders Orders. Samuel Belaney and Elijah Barnes were elected to that office. Conference proceeded to the examination of the characters of Elders Allen Wiley, Enoch G. Wood, James Jones, Charles M. Holliday, William M. Reynolds, William Shanks, Joseph Tarkington, C. W. Ruter and John Burns, their characters were severally examined and passed. Bro. I. W. McReynolds asked and received a superannuation. Voted, that William Shanks be left without an appointment at his own request the ensuing year. Conference adjourned.

Saturday morning, 8 o'clock, conference met pursuant to adjournment and was opened according to rule. Conference proceeded to business, Bishop Roberts in the chair. On motion the vote taken yesterday 
in the case of William Rector, was reconsidered and he was elected to the office of a deacon. Nathaniel Warren, recommended for Deacon's orders, and elected. Conference resumed the examination of the characters of the elders. John Miller, H. S. Talbott, James Havens, E. R. Ames, Robert Burns, Charles Bonner, Isaac Kimball, Spencer W. Hunter, were examined, approved and passed. The relation of Bro. Talbott was changed from superannuate to effective. Bro. Kimball, through his representative, asked and obtained a location. Voted that Bro. J. W. Hunter be left without an appointment at his own request. The case of Bro. Oglesby was called up and objections were made to him on the ground that he had made expressions which were supposed to be inconsistent with the doctrines of our church and he was called upon to give explanations. After some considerable discussion, on motion, a committee of three, viz: C. W. Ruter, E. R. Ames and $\mathrm{R}$. Lewis were appointed to draft a report and resolutions on the subject and present them to this conference at this afternoon's session. Conference adjourned.

Saturday, 2 o'clock p. m., conference met pursuant to adjournment and was opened according to rule, Bishop Roberts in the chair. Conference proceeded to business. The committee appointed in the case of Bro. Oglesby presented their report which was read and amended and in part adopted when, on motion, the further consideration of the case was laid over until Monday next. Conference adjourned.

Monday, 8:30 o'clock a. m., conference met pursuant to adjournment and was opened according to rule, Bishop Roberts in the chair; conference proceeded to business. Conference resumed the consideration of Bro. Oglesby; the committee with permission withdrew that part of their report which conference had not acted upon and that part of the report which had 
been acted upon by the conference reads as follows: "Your committee appointed in the case of Bro. Oglesby have had the same under consideration and beg leave to report that they think Bro. Oglesby's manner of expression relative to the doctrine of human depravity objectionable (however sound he may be in principle) and in view of this we recommend to the conference the adoption of the following resolution, viz: Resolved, That the conference respectfully request the superintendent to admonish Bro. Oglesby not to disseminate his peculiar views on that subject."

The Bishop informed the conference that he had complied with the request and had conversed with and admonished Bro. Oglesby and that he received it in the spirit of christian humility and love. Bro. Oglesby then made a full explanation to the conference, which being perfectly satisfactory, his character was approved and passed. The characters of John C. Smith, W. H. Smith, John T. Johnson, Ancel Beach, Amos Sparks, Asa Beck, Aaron Wood, Samuel I. James, L. Thompson, Samuel Julian, Samuel C. Cooper, John Ritchie, Boyd Phelps, Miles Huffaker, H. Vredenburgh, Richard Hargrave were severally examined, approved and passed. William $\mathrm{H}$. Smith asked and obtained a superannuated relation and Amos Sparks and Samuel Julian located. Conference adjourned.

Monday, 2 o'clock p. m., conference met pursuant to adjournment and was opened according to rule. Bishop Roberts in the chair, conference proceeded to business. Conference resumed the consideration of the characters of Elders. Richard L. Robinson, Daniel Anderson, John Ray and Thomas I. Brown were severally examined, approved and passed. Bros. Ray and Robinson obtained a superannuated relation and Bro.

1 Ogleshy was suspected of leaning toward Pelagianism, a doetrine denying the total depravity of man and insisting that man, by the decision of his will, made a conscious choice between good ancl evil. (Holliday. Indima Methodism, 122.) 
Anderson asked and obtained a location. On motion, the vote by which John W. Sullivan was admitted, was reconsidered, and after some discussion, the vote being taken, he was admitted on trial. Voted that conference continue its present session until $4: 30$ o'clock. Conference then proceeded to the election of delegates for the ensuing General Conference and on counting the votes, C. W. Ruter, Allen Wiley, James Haven and James L. Thompson were declared duly elected. Conference adjourned.

Tuesday, 8:30 a. m., conference met pursuant to adjournment and was opened according to rule; Bishop Roberts in the chair, conference proceeded to business. On motion, conference proceeded to elect two reserved delegates for the ensuing General Conference and on counting the votes, Aaron Wood and William Shanks were deciared elected. The number of membership in the church being called for, was then reported. Conference then proceeded to the consideration of a suitable place for holding the next session and on counting the votes, Indianapolis had a majority, and was announced as the place of holding the next session of this conference. Whereupon conference adjourned.

Tuesday, 2 o'clock p. m., conference met pursuant to adjournment and was opened according to rule, Bishop Roberts in the chair; conference proceeded to business. On motion, resolved that a committee of three be appointed to draft resolutions on the subject of the abolition question, 2 and the superintendent ap-

2 It might be interesting here to note that the sentiment of the Methodist church, while opposed to slavery as a moral wrong. was nevertheless strongly against abolition. Peter Cartwright, in his Autobiography, has the following to say about the churehs attitude toward the slavery question: "Prior to the (reneral Conference of 1836 the rum-mad spirit of rabid abolitionism had broken out in some of the Eastern and Northern Conferences, and Methodist preachers were found by the dozen to quit their apfropriate fields of labor, and their holy calling of saving souls, 
pointed Rodman Lewis, Smith L. Robinson and John C. Smith said committee. The stewards of conference presented their report which was read and adopted and a balance being on hand was, on motion, voted by the conference to be paid over to Daniel Anderson. The committee on books and periodicals presented their report, which was read and adopted. C. W. Ruter, who was two years since appointed a committee to adjust the papers of our deceased Bro. Strange, and if practicable collect any money that may be due to his estate, presented a verbal report, stated that he had not been able to collect any money and return the papers to the conference, and on motion, they were returned to the widow of Brother Strange by the hand of Brother Tarkington. The agent, C. W. Ruter, who was elected last year to receive the bequest of James Paxton, deceased, presented his report, which was adopted and his agency continued. Conference adjourned.

Wednesday, 8:30 o'clock a. m., conference met pursuant to adjournment, and was opened according to rule, and conference proceeded to business, Bishop Roberts in the chair. On motion, it was resolved that a committee of one be appointed whose duty it should be to have the memorial presented by this conference to the Legislature, last year, on the subject of the Bloomington College, published in some public journal,

and turu out and berone hired lecturers against slavery.

Ir. Fisk was a good man and true, and was as much opposed to slavery as any of them. yet he was for occupying real Methodist mercher groma, and bearing his plain. honest testimony agilust the morm evil of slarery, and not meddling with it politically only in a comstitutional way" (p. 36.3.)

In the General Conference of 1 s: which met in Cincimati. a resolution was passed condemning "Mfodern abolitionism, and wholly dischiming any right, wish or intention to interfere in the (divil and political relations hetween master and slave as it exists in the slave holding states of the rnion." (swet. Methodist Episcopal (hurch and the Civil War, p. 20.) 
in this state, with such remarks as he may think proper. C. W. Ruter was nominated and elected that committee. The Bishop then appointed a committee to examine the graduates at the next conference. Allen Wiley and William Shanks were appointed to examine on theology and church government; Aaron Wood on church history and geography; E. R. Ames on grammar, history, philosophy and logic, and C. W. Ruter on the books prescribed in the course of study. On motion, resolved that an agent be appointed to attend to and promote the interests of the Preacher's Aid Society of the Indiana Annual Conference. The mission committee presented their report, which after being read, was adopted. The following resolution was laid before the conference: Resolved by the Indiana annual conference that the ensuing General Conference be requested to restore to our discipline Mr. Wesley's original rule on the subject of "Ardent Spirits"3 a rising vote being called, 43 members present, all voted in the affirmative-said resolution was adopted. The

3 This rule, which stated that "drunkenness, buying or selling of spirituous liquors, or drinking them, unless in cases of extreme necessity," should he avoided, had early been abandoned by the Methodist church in America. Under the ruling at this time only ministers were forbidden the buying and selling of liquors, memhers being permitted its sale, providing they permitted no disorderly conduct on their premises. (Western Christian Advocate, September 1s, 1\$35. Editorial on a similar resolution passed by the Ohio Conference.)

Peter Cartwright in his account of his trip to the General Conference of 1824 at Baltimore, in the company of Jesse Walker, Samuel Thompson and a certain F. S.. states that at every stop F. S. and Walker called for spirits. Cartwright and Thompson protested. whereupon the other two preachers defended the practice. Cartwright and Thompson then threatened to quit their company if they continued this practice, and in this way they were persulted to stop using liquors for this time at least. This incident well illustrates the attitude of most Methodist people towarl the use of liquors at this time. (Peter Cartwright's Autobiography. pp. 213-214.) 
committee on education presented their report which was read and recommitted with instructions to report in the afternoon session. The committee on abolition presented their report, which was read, and on motion, adopted. Conference adjourned.

Wednesday, 2 o'clock p. m., conference met pursuant to adjournment and was opened according to rule, Bishop Roberts in the chair; conference proceeded to business. On motion, Brother Wiley was directed to pay to the treasurer of the Preacher's Aid Society the amount of the bequest of Swearingin, by him collected. The committee on education presented their report, embracing a plan for raising funds and establishing a college which was read and, on motion, adopted. The report read as follows:

Your committee on the subject of education have had the same under consideration and beg leave to report that in their opinion the interest of the rising generation are deeply involved in the cause that shall be taken by this conference and that in view of the vast and increasing numbers within the bounds of the Indiana annual conference who are under the influence of Methodism and are looking to this branch of the church to give direction to the minds of the youth on the subject of education and in view of the relation in which we stand to the church and community as a body of ministers; it becomes our imperious duty to make a united and persevering effort to establish a system of education which shall meet the wishes or wants of the people who look to us to take the lead in this important undertaking. We therefore recommend to the conference the following plan for the raising of funds and establishing a college or university which shall be called the Indiana Asbury University of the Indiana annual conference:

First. Let a stock be created to consist of an in- 
definite number of shares of one hundred dollars each, payable in money, to be put at interest or in notes bearing interest payable in five annual installments, and the interest to be paid annually at the time of paying each instalment; provided that whenever a stockholder shall commence sending a student he shall have paid at least one instalment.

Second. Each stockholder shall be entitled in virtue of his share, to send one student to the college six years or twelve sessions, subject to all the regulations of the by-laws and if any one shall have more shares than one he shall be entitled to the privilege of sending more students than one according to his shares.

Third. Any person who may desire it shall have the privilege of subscribing a half share or fifty dollars, and shall do it on the same terms of payment as those who take whole shares. And any person having a half stock may send one student for three years or six sessions.

Fourth. Let ten thousand dollars be the endowment of a professorship.

Fifth. Let two hundred and fifty dollars be the price of a scholarship for a term of 20 years.

Sixth. Let donations of five dollars and upwards be obtained towards endowing a professorship and let those donations be received in money or notes bearing interest and payable in annual instalments of $\$ 5.00$ and the interest payable annually.

Seventh. Let there be established a dollar subscription payable within the current year in money towards endowing the professorship above mentioned.

Eighth. Let all the intinerant preachers and especially Presiding Elders act with energy as agents and in addition to this let a special agent be appointed to travel within the bounds of this conference and solicit donations for carrying into full effect the foregoing 
arrangements and if practicable another agent to travel elsewhere for the same purpose.

Ninth. Petition the Legislature for an act of incorporation fixing the number of trustees and so forth and for an endowment for one or more professorships.

Tenth. Let there be a subscription paper circulated in two or more prominent towns by way of competition to ascertain in what place the greatest amount for erecting suitable buildings be given by the people on condition of its location among them or in their vicinity.

Eleventh. At a convenient time send an agent into the eastern cities to obtain by donation books for a library, etc. All of which is respectfully submitted.

On motion, resolved that the secretary furnish each Presiding Elder with an abstract of the report and on motion the conference proceeded to elect the several committees to act in the principal towns in this state to carry into effect the object contemplated in the tenth article. Rev. James Haven, John Wilkins and Calvin Fletcher at Indianapolis. Rev. A. Wiley, Hon. William Hendricks and John Woodburn in Madison. Rev. Aaron Wood, John Jackson, and Elisha U. Brown at Terre Haute were elected. On motion, resolved that a vote of thanks be given to the citizens of Lafayette for their kind hospitality to the members of this conference during its present session. On motion, resolved that a vote of thanks be given to the members of the Presbyterian Church for the use of their house during the session of this conference. Resolved that this conference instruct its delegates to the next General Conference to consent that the northern boundaries of this state shall be the bounds of this conference. ${ }^{4}$ On motion, resolved that Rev. A. Wiley pay over to the treasurer of the Preachers' Aid Society the amount of money left in his hands by the last conference being 
the bequest of Swearinger. On motion, the appointments were read out and conference adjourned.

R. R. ROBERTS.

C. W. RUTER, Secretary.

APPOINTMENTS FOR 1835.

Madison District, A. Wiley, Presiding Elder.

Madison Station-W. V. Daniel.

Vevay Circuit-J. Jones, H. J. Durbin.

Lawrenceburg Circuit-R. Lewis, D. Stiver, J. V. Watson.

Erookville-B. Phelps, L. M. Reeves.

Liber'ty-G. M. Beswick, J. M. Stallard.

Greensburg-C. Bonner.

versailles-M. Hufiaker.

Verron-W. W. Hibben.

Charlestown District-C. W. Ruter, Presiding Elder.

Charlestown-I. M’Elroy, J. S. Bayless.

New Albany Station-E. G. Wood.

Jeffersonville Station-Z. Games.

Corydon-G. C. Shively, J. W. Sullivan.

Greenville-J. Tarkington.

Salem-J. Kern, M. Reeder.

Paoli-E. Whitten.

Lexington-G. K. Hester.

Brownstown-E. Patrick.

E. R. Ames, Agent for the Preachers' Aid Society. Indianapolis District-J. Havens, Presiding Elder. Indianapolis Station-J. C. Smith.

Indianapolis Circuit-D. H. Dickerson.

+ The Illinois Conference was divided in the general Conference of 1832 and the Indiana conference was formed out of the Western portion of it. This new conference included, in addition to the state of Indiana. a small portion of southern Michigan and Elizabethtown. Ohio. The above resolution simply asked that the conference include the state of Indiana alone. 
Rushville-R. Burns, T. Gunn.

Connersville-J. T. Johnson, F. C. Holliday.

Wayne-J. Carter, C. W. Appleton.

Winchester-C. Hall.

Newcastle-C. B. Jones.

Pendleton-H. Griggs.

Noblesville-J. Harbin.

Marion-J. T. Robe.

Bloomington District-J. Oglesby, Presiding Elder.

Bloomington Station-W. M. Dailey.

Bloomington Circuit-W. Duncan.

Greencastle and Putnamville Stations-A. Johnson.

Danville-I. G. Lewis.

Mooresville Circuit-A. Beck.

Franklin-T. J. Brown.

Columbus-L. Hurlbert.

Bedford-L. D. Smith.

Vincennes District-A. Wood, Presiding Elder.

Vincennes Station-J. Daniel.

Princeton Circuit-G. Tevebaugh.

Booneville-E. Vanschoick.

Rome Mission-D. Stucker.

Washington-J. White.

Otter Creek Mission-S. C. Cooper.

Terre Haute Station-S. L. Robinson.

Terre Haute Circuit-T. Ray, T. Bartlett.

Carlisle-E. Wood.

Evansville-I. Owen.

Crawfordsville District-J. L. Thompson, Presiding Elder.

Crawfordsville Station-J. Miller.

Crawfordsville Circuit-C. Swank.

Rockville-E. Sewel, W. T. Madaras.

Lafayette-C. M. Holliday, J. Richey.

Lafayette Station-H. S. Talbott.

Frankfort-A. Beach.

Carroll-E. Rogers. 
Pine Creek-H. Vredenburgh, W. Watson.

Cole Creek Mission-D. DeMott.

Lebanon Mission-B. Griffith.

Laporte District-R. Hargrave, Presiding Elder.

Laporte Circuit-R. C. Meek, one to be supplied.

South Bend-J. Wolf.

Cassopolis-T. P. McCool.

St. Joseph-E. Kellogg.

Elkhart-S. R. Ball.

Kalamazoo-S. S. Williams.

Fort Wayne Mission-J. S. Harrison.

Deep River Mission-S. Jones.

Logansport-J. A. Brouse.

FIFTH SESSION OF THE INDIANA CONFERENCE, INDIANAPOLIS, 1836.

Journal of the fifth annual session of the Indiana Conference of the Methodist Episcopal Church ${ }^{1}$ held in Indianapolis, October 26, 1836.

Wednesday, 9 o'clock a. m., Conference met according to appointment, and no superintendent being present, on motion Allen Wiley was called to the chair, who opened the conference by reading a portion of the Holy Scriptures, singing and prayer. The list was called and the following members being present answered to their names, viz.: Allen Wiley, Rodman Lewis, Lemual L. Reeve, Miles Huffaker, Enoch G. Wood, John Kern, E. R. Ames, John C. Smith, Amasa Johnson, Aaron Wood, Joseph White, Thomas Ray, James L. Thompson, Henry L. Talbott, H. Vredenburg, Stephen R. Ball, John A. Brouse, William H. Smith, James Jones, David Stiver, Charles Bonner, C. W. Ruter, Joseph Tarkington, Elijah Whitton, James Havens, William M. Dailey, Thomas J. Brown, John Dan-

1 The chmreh was on the corner of Meridian and Circle streets. John $\triangle$. smith was the prearher in eharge. (Indiana Methodism. Hollidis. 272.) 
iel, Samuel C. Cooper, Enoch Wood, John Miller, Ancil Beach, Richard Hargrave, James L. Harrison, William Shanks, Richard L. Robinson.

C. W. Ruter was chosen secretary and E. R. Ames assistant secretary. Conference then proceeded to elect by ballot a president pro tem, and on counting the votes Allen Wiley was declared duly elected. Conference then voted to fix the time of meeting at 8 o'clock and adjournment at $12 \mathrm{~m}$. James Havens, J. C. Smith and C. W. Ruter were nominated and elected a committee to appoint the preachers to officiate and to superintend the congregations. The by-laws of the first session of the Indiana Conference were read and adopted for the government of the conference of the present session.

On motion of T. J. Brown, resolved, that during the session of this conference none of its members are to use tobacco or defile the floor by spitting, and every brother is particularly requested to avoid it.

W. Shanks, E. R. Ames and S. C. Cooper were elected as conference stewards.

On motion, resolved, that a committee of seven, one to be taken from each presiding elder's district, be appointed to be denominated as the Committee on Education, whose duty it shall be to inquire into the situation of the place or places which may be prepared as suitable sites for the location of a Conference College, the amount subscribed at each, the general health of the town and surrounding country, their relative distance from the center of the conference and report the same to this conference as soon as possible. And that said committee be also directed to review the report of the Committee on Education of last conference and suggest such additions as they may deem expedient.

Resolved, That a committee of seven, to consist of one preacher in charge from each district be appointed 
to be denominated the Committee on Itinerancy, whose duty it shall be to examine into the general state of the work within the bounds of the Indiana Conference and report any usages which in their opinion are inconsistent with the original design or spirit of our itinerancy and to report as soon as practicable.

Conference proceeded to the consideration of the first question on the minutes, viz.: Who are admitted on trial? William H. Goode and Ezra L. Kemp, recommended from Charlestown District, were admitted; John H. Bruce, William Fraley and Jared B. Mershon, recommended from Crawfordsville District, were admitted. And the case of John M. Cole from the same district was on motion laid over. John F. Truslow, recommended from the Indianapolis District, and R. $R$. Bints, Anthony Robinson and Wade Poesy, recommended from Vincennes District, were admitted.

The president announced the Committee on Education to consist of A. Wiley, C. W. Ruter, James Havens, Joseph Oglesby, Aaron Wood, Samuel Thompson, and Richard Hargrave. And the Committee on Itinerancy to consist of R. Lewis, S. G. Wood, J. C. Smith, T. J. Brown, John Daniel, J. Miller and R. S. Ball.

Whereupon conference adjourned.

Thursday, 8 o'clock a. m., Conference met pursuant to adjournment, and was opened according to rule, Mr. Allen Wiley in the chair. Conference proceeded to business. The case of John M. Cole was called up and he was admitted on trial. Isaac Kelso recommended from Vincennes District, Francis M. Richmond from Indianapolis District, James D. Sanford, George M. Boyd, Hawley B. Beers and Jacob Colclasier from Laporte District, William D. Cox, David J. Cox, G. C. Beeks from Madison District, Isaac Welch, Philip Seay, John Sinclair from Bloomington District, were admitted on trial, and James Scott was readmitted. Ezra Munson was not admitted but on motion the 
Presiding Elder has leave to employ him when necessary.

H. A. Tarkington applied for readmission but was rejected. A motion was made that Amos Sparks should be admitted but it did not prevail. It was decided by a vote of Conference that the children of those preachers who have received their table expenses in the bounds of their different fields of labor shall nevertheless be claimants on quarterage money. Conference then took up the second question, viz.: Who remain on trial? Ebenezer Patrick, John W. Sulliman, Thomas P. McCool, Stephen Jones, Eli Rogers, Israel G. Lewis, Daniel Demott were continued on trial. George C. Shively and H. J. Durbin were discontinued at their own request. Joseph Wolf, William S. Medaris and Elijah Vanschoik were discontinued. Collreth Hall, Jacob M. Stallard, Benjamin Griggith, W. W. Hibben were continued and Teverbaugh was discontinued.

Conference adjourned.

Friday, 8 o'clock, conference met pursuant to adjournment and was opened according to rule. Rev. A. Wiley in the chair. Conference proceeded to business. Conference then proceeded to the consideration of the second question in the minutes. Elijah Sewall was continued on trial and Warren Duncan was discontinued but on motion the presiding elder has leave to employ him. C. W. Appleton was discontinued at his own request. C. B. Jones, Erastus Kellog and Isaac McElroy were continued on trial. Conference resumed the consideration of the first question on the minutes.

Solomon Miller, recommended from Laporte District, and John Newell, from Bloomington District, were admitted on trial. The report of the Committee on the Itinerancy of the last General Conference was presented, read and ordered to be spread on the Journal. An address from the New York book agent was 
read and on motion a committee of three was appointed to be denominated as the Book Committee to whom all papers and those connected with the business should be referred. S. L. Robinson, William M. Dailey and A. Beach were appointed that committee.

Resolved, That a copy of the said report on Itinerancy be spread on the Journal of each Quarterly Meeting Conference.

The stewards spent some time in attending to the pecuniary concerns of the Conference.

Conference voted to draw on the Book Concern for four hundred dollars, and on the Chartered Fund for seventy-five dollars. On motion the vote taken yesterday on the Stephen Jones case was reconsidered and he was discontinued at his own request.

Conference passed to the consideration of the third question on the minutes. William V. Daniel, Lewis Hulbert, Thomas Gunn, Thomas Bartlett, Isaac Owen, Sanford L. Williams and F. C. Holliday, having been previously examined by the committee appointed for that purpose, were called up by the president and questioned as the discipline directs. Their characters were then examined and passed, and they were admitted into full connection. Also elected to Deacons Orders. Joseph Carter, D. H. Dickinson, S. P. Moore and M. Reeder were discontinued. J. S. Bayless and David Stucker were, at their own request, continued on trial.

Conference adjourned.

Saturday, 8 o'clock a. m., Conference met pursuant to adjournment and was opened according to rule. Bishop Roberts having arrived took the chair and proceeded to business. The Committee on Education presented their report in part which was read, and after some amendments was adopted.

On motion, resolved, that a member of each of the delegations from the different towns inviting the location of the proposed institution be invited to take a 
seat within the bar and take part in the discussion on the subject of its location, and General Howard, of Rockville; Doctor Cowgill, of Greencastle; J. Townsend, of Putnamville, and C. Fletcher, of Indianapolis, took their seats in Conference and after some discussion $^{4}$ the Conference adjourned to meet at 6 o'clock p. $m$.

Saturday, 1 o'clock p. m., Conference met pursuant to adjournment and was opened according to rule. Bishop Roberts was in the chair. Conference proceeded to business. The subject of the location of the institution of learning was again brought up and the discussion continued. General Howard made a few additional remarks and also Doctor Cowgill. The Conference was then addressed by Esquire Townsend and followed by Doctor Talbott who was succeeded by Esquire Fletcher. The discussion being closed, the Conference proceeded to fix, by ballot, the location of the said institution. And on the second balloting, Greencastle, of Putnam County, having the majority of all the votes given was fixed upon as the place for its location.

It was then resolved that a vote of thanks be returned to the citizens of the several places which have solicited the location of our contemplated institution of learning for their liberal subscriptions and especially to the citizens of Rockville.

Conference then proceeded to the fourth question on the minutes, viz.: Who have been elected and ordained Elders? The characters of John Daniels,

4 Calvin Fleteler, representing Indianlpolis, did not labor bard for the institution. saying that it was not good for boys to be away from lome in as large a place as Indiananolis would be some day. When Genelat Inward admitted that there were some rhills and fever at Rorkille. $\mathrm{Ir}$. Flether eren amitted some eren died at Iudianapolis: hut Dr. Cownill silil. "People never die at Greencastle: although for convenience they lave a cemetery there." (Antohiograplyy of Jas. Tarkington. 1p. 131-192.) 
Thomas Ray, Joseph White, Elijah Whitton, Enoch Wood were severally examined and elected to Elder's Orders.

Conference then took up the case of local preachers. The following were recommended for Deacon's Orders : William W. Hibben, John Kisling, Thomas F. Spillman and P. S. Silvy, from Madison District; Waller Benton, Charles Bruner, John W. Sullivan, John Earnheart and Thomas Ryson, from Charlestown District; John Robbins, John Romsil, F. Farnsworth, George Smith, John Alman, F. M. Richmond, William Perkins and Elijah Sims, from Indianapolis district; John Peters, William Terrel, John A. Spicer, John Clinger and B. Bales, from Bloomington district; James Bonner, Samuel Barcourt, George Teverbaugh and Benjamin Bushnell (a man of color) from Vincennes district; C. Gem and Daniel Demott from Crawfordsville district; B. Robinson and Cyrus Spinlock from Laporte district; all of which were duly elected.

Conference then took up the case of local deacons. The following were recommended for local Elders Orders: Alfred Phelps, Jonathan Shaw, Henry Romwell, Thomas Lowry, E. Patrick, F. A. Stauderford and Edward Jones; these were duly elected to that office.

Conference adjourned.

Monday, 8 o'clock a. m., conference met according to adjournment and was opened according to rule. Bishop Roberts was in the chair.

The committee appointed to estimate the table expenses of Bishop Roberts reported an appropriation of three hundred dollars per annum, which was consented to by the conference. H. A. Tarkington, recommended for Elders Orders, was elected. The president appointed A. Wiley, C. W. Ruter and S. L. Robinson to draft a charter for the institution of learning estab- 
lished by this conference to be presented as soon as possible.

Conference proceeded to the examination of the characters of Elders. Resolved, that conference sit with closed doors during the examination.

The characters of A. Wiley, James Jones, ${ }^{5} \mathrm{~J}$. W. Hunter, Rodman Lewis, Boyd Phelps, George M. Beswick, Charles Bonner, Miles Huffaker, C. W. Ruter, Enoch E. Wood, Joseph Tarkington, John Kern, L. Games and E. R. Ames were examined, approved and passed. James Haven's name was called and objections being raised by Brother Oglesby, Brother Havens requested that a committee be appointed to investigate his character, and on motion, a committee of five, viz: A. Eddy, John Miller, A. Wood, John Kern and S. C. Cooper were appointed for that purpose.

The characters of J. C. Smith, Robert Burns, J. T. Johnson were examined, approved and passed. Brothers Games, Burns and Johnston each asked and received location.

The characters of James T. Robe, Wm. M. Dailey, Amasa Johnson, Asa Beck, Aaron Wood, S. C. Cooper, James L. Thompson, John Miller, Cornelius Swank, C. M. Holliday, John Richie, H. S. Talbott, Ancil Beach, H. Vredenburg, Richard Hargrave, William Shanks, John W. McReynolds, Wm. H. Smith, R. S. Robinson, John Ray, George H. Hester, David Stiver were severally examined, approved and passed. Brothers Beck and Richie asked and received a superanuated relation. Brothers McReynolds, Ray and Smith were continued in the superanuated relation, and $\mathrm{Wm}$. Shanks obtained a supernumerary relation and the relation of $\mathrm{R}$. S. Robinson was changed from superanuated to effective. L. D. Smith was called and

5 Rev. James Jones, while pastor at Lawrenceburg. during his second year. receired almost 600 persons into the church. (J. C. snitl. "Early Methodism in Indiana," p. 193.) 
some objections being raised in consequence of his having failed to go to the work assigned him last conference, his character did not pass and by his representative asked and obtained a location. T. Truslow, a local preacher, was recommended for Deacons Orders and was elected and Wm. Hunt, recommended for Elders Orders, was elected.

Conference adjourned.

Tuesday, 8 o'clock a. m., conference met pursuant to adjournment and was opened according to rule. Bishop Roberts was in the chair. Conference proceeded to business. The stewards of the conference presented their report, which was read and accepted, said report declared a dividend of 42 per cent. The entire deficiency was $\$ 550.50$, leaving a small balance in the hands of the stewards.

On motion, Resolved, that hereafter any preacher failing to present to the stewards of conference, official statements of their claims and receipts, shall not have a claim on the funds of this conference.

Resolved, that ten dollars of the surplus in the hands of the stewards be appropriated to D. H. Dickerson and ten dollars to Asa Beck to make up a deficiency that was made through a mistake in the case of those brethern last conference.

Resolved, that monies appropriated to the children of our deceased brethern be forwarded to their surviving parent.

Conference proceeded to the consideration of the fourth question on the minutes, viz: Who are the Deacons? The characters of W. D. Watson, John A. Brouse, Stephen R. Ball, Hiram Grigg, James L. Harrison, R. C. Meek, J. C. Harbin, L. M. Reeves and J. V. Watson were severally examined, approved and passed and W. D. Watson and J. V. Watson asked and received location.

The certificate of the recording steward of the 
Danville circuit, signed by the president of quarterly meeting conference, was submitted to this conference certifying that J. C. Faulkner, a local deacon who had been expelled from the church, was restored to his former standing and a motion was made that his parchments should be restored to him, which after some discussion, the vote being taken, it was decided in the negative.

On motion, the vote by which James Scott was readmitted into this conference, was reconsidered, and after some discussion, Brother Scott was invited in to answer some questions on doctrinal points in order to satisfy the minds of some of the brethern, as to the soundness of his faith. He made some statements and answered several questions on the doctrine of original sin, which were proposed by the bishop and others. Upon retiring, a vote was taken and he was admitted a member of this conference.

Resolved, that in our opinion the discipline does not authorize the expulsion of members for not paying quarterage. Resolved, that we disapprove of the course of Brother Oglesby in appropriating the fourth collection not according to the discipline.

Brother Oglesby, having retired, on motion, his character was passed and he received a superanuated relation.

Conference adjourned.

Wednesday, 8 o'clock a. m., conference met according to adjournment and was opened according to rule. Bishop Roberts in the chair and the conference proceeded to business.

Brother Oglesby asked and obtained a location. The book committee presented their report, which was read and accepted and ordered to be filed among the papers of the conference.

The stewards spent some time in adjusting their business. On motion, J. White received the balance 
remaining in the steward's hands. Conference proceeded to take the numbers in societies, etc.

Conference then proceeded to elect by ballot two college agents and on counting the votes, Aaron Wood and John C. Smith were declared duly elected. The committee on itinerancy presented their report, which was read and adopted.

Conference adjourned.

Thursday, 8 o'clock a. m., conference met pursuant to adjournment and was opened according to rule. The list was called, journal read and approved. Conference proceeded to business. Bishop Roberts in the chair. Brother S. L. Robinson, by his representation, asked and received a superanuated relation.

The committee appointed to examine certain complaints made against James Havens, presented their report, which was as follows: The committee to whom were referred certain complaints against the character of James Havens have had the same under consideration and beg leave to report that after hearing all the evidence adduced in the case and bestowing the most careful investigation, vour committee find nothing to support the accusation, nor anything that goes to impeach the character of Brother Havens, either directly or indirectly.

Respectfully submitted,

\section{A. EDDY, Chairman.}

Which report, having been read, was on motion, adopted, and his character approved and passed.

The case of Joseph Oglesby was called and some objections in the form of charges were made against him by a local preacher from Bedford circuit.

First, for ordering the stewards and leaders of Bedford circuit to bring before the church all those members who do not pay quarterage and ordering the preacher in charge to expell them. Second, contending for and receiving half of the public collections at 
the quarterly meetings. Brother Oglesby made some statements and explanations and after some discussion, the following resolution were adopted: Resolved, that we disapprove of the course of Brother Oglesby in dividing the public collections as not being according to the discipline.

The committee on education presented their report containing a charter for the institution of learning founded by this conference, which was read, amended and approved. On motion, the presiding elder of the Indianapolis district and C. Fletcher were appointed to attend to its passage in the Legislature, who were authorized to admit any alterations or amendments which in their opinion will not be fatal to the interest of the institution.

The committee on education also presented an address to the people within the bounds of this conference on the subject of Education, which was read, approved and ordered to be signed by the president and secretary, to be prepared for the press and forwarded to the editor of the Western Christian Advocate for publication. Said committee also presented a further report relative to an address from the stewards and leaders meeting of New Albany Station praying the conference to take under its patronage the New Albany Seminary ${ }^{\top}$ and recommending the adoption of the following resolution: Resolved, that the conference comply with the request contained in said address as it relates to the patronizing of said institution, which was adopted. Conference proceeded to the election of trustees. A. Wiley, W. V. Daniel, E. R. Ames, C. W. Ruter and Wm. Shanks were nominated and elected trustees of said seminary. And the president appointed

7 The Western Christian Advocate for November 17, 1837, states that the New Albany Seminary was opened for students in the autumn of 1836. During the first and second sessions the number of students was about 80 in the male department and 60 in the female department. 
the presiding elder of Charlestown district together with A. Wood and J. C. Smith a board of visitors, whose duty it shall be to attend the annual examination of said seminary and report to the next session of this conference.

Conference then proceeded to fix the place of its next session, and on counting the votes, New Albany was the place. R. S. Robinson was nominated and elected a member of the missionary committee to fill the vacancy occasioned by the absence of Boyd Phelps. On motion, Resolved, that a vote of thanks be given to the members of the Presbyterian and Baptist Churches for the use of their meeting house, during the session of this conference, which shall be published from the pulpit next Sabbath.

On motion, conference adjourned to meet in the Methodist Church tomorrow at 8 o'clock a. m.

Friday, 8 o'clock a. m., conference met pursuant to adjournment and was opened according to rule. Bishop Roberts in the chair. On motion, the agent who was appointed to attend to the business relative to the legacy of James Paxton, was instructed to collect the money and loan it out for the same interest that the managers loan the funds of the Aid Society. The committee on missions presented their report, fixing the amount necessary for the missions within the bounds of this conference at $\$ 1,120.00$, which was adopted.

On motion, Resolved, that a vote of thanks be tendered to the citizens of this place for their kindness to the preachers and their liberality in the support of our benevolent institutions.

On motion, Resolved, that the president of the conference be requested to furnish the college agents with such instructions as he may think necessary relative to the duties assigned them.

On motion, after singing and prayer and a short 
address by the president, the appointments were read out and conference adjourned to meet at New Albany, Indiana, on the twenty-fifth of October, 1837.

R. R. ROBERTS.

C. W. RUTER, Secretary.

APPOINTMENTS FOR 1836.

Madison District.

E. G. Wood, Presiding Elder.

Madison-Rodman Lewis.

Vevay-Joseph Tarkington, Lewis Hurlbert.

Lawrenceburg-James Jones, William B. Ross.

Brookville-Isaac Kelso, one to be supplied.

Liberty-Boyd Phelps.

Greensburg-James Scott, L. M. Reeves.

Versailles-Miles Huffaker.

Vernon-George K. Hester.

John C. Smith.

Charlestown District.

C. W. Ruter, Presiding Elder.

New Albany-Allen Wiley.

Corydon-Isaac Owen, J. M. Stallard.

Greenville-Sanford S. Williams.

Paoli-James T. Robe.

Salem-John Kearns, Wm. Shanks, sup.

Brownstown-Ezra L. Kemp.

Lexington-William H. Good.

Charlestown-Wm. V. Daniel, Thomas S. Gunn.

Jeffersonville-John S. Bayless.

Indianapolis District.

James Havens, Presiding Elder.

Indianapolis Station-Augustus Eddy. plied.

Indianapolis Circuit-C. B. Jones, one to be sup- 
Shelbyville-Elijah Whitten.

Rushville-Fernandes C. Holliday, John F. Truslow. Connersville-David J. Cox, John W. Sullivan.

Pendleton-Philip May.

Noblesvilie-Hiram Griggs.

Danville-Isaac Welch.

Edward R. Ames, agent for Preachers' Aid Society.

Bloomington District.

S. C. Cooper, Presiding Elder. Bloomington-Wm. M. Dailey.

Springville-Benjamin T. Griffith.

Bedford-Ebenezer Patrick.

Columbus-Wm. W. Hibben, William D. Cox. Franklin-Charles Bonner, one to be supplied. Mooresville-Israel G. Lewis.

Greencastle-John Newel. Putnamville-Thomas Ray. Spencer-Enoch Wood.

Vincennes District.

John Miller, Presiding Elder. Vincennes-John Daniel.

Terre Haute Station-J. A. Brouse.

Terre Haute Circuit-J. Sinclair, Sol. Miller.

Carlisle-Anthony Robinson, one to be supplied.

Washington-Thomas Bartlett.

Princeton-Jesse C. Harbin.

Mt. Vernon-Isaac Mcelroy, one to be supplied.

Boonville-David Stucker.

Rome Mission-John M. Cole.

Knox Mission-Ransford R. Burts.

Aaron Wood, college agent.

Crawfordsville District.

James L. Thompson, Presiding Elder. 
Crawfordsville Station-Amasa Johnson.

Crawiordsville Circuit-Thomas J. Brown.

Rockville-Charles M. Holliday, J. H. Bruce.

Cole Creeln Mission-Daniel Demott.

Covington-Cornelius Swank, E. Sewell.

Pine Creek-Ancil Beach.

Lafayette-Henry S. Talbott.

Delphi-Jared B. Mershon.

Monticello Mission-H. Vredenberg.

Dayton-Joseph White.

Frankfort-Eli Rogers.

\section{Laporte District.}

Richard Hargrave, Presiding Elder.

Laporte-George M. Boyd, one to be supplied.

South Bend and Mishawaka-Richard S. Robinson.

Niles-Thomas P. McCool, one to be supplied.

Kalamazoo-Erastus Kellogg, H. B. Beers.

St. Joseph-Richard C. Meek, James D. Sanford.

Elkhart-James S. Harrison.

Logansport-B. Westlake.

Plymouth Mission-William Fraley.

Deep River Mission-Jacob Colclazer.

\section{Centerville District.}

David Stiver, Presiding Elder.

Centerville-George M. Beswick, one to be supplied. Winchester-Colbreth Hall.

Newcastle-Francis M. Richmond.

Munceytown-Greenbury C. Beeks.

Fort Wayne Mission-Stephen R. Ball.

Mississinewa Mission-Wade Posey.

John W. McReynolds and Spencer W. Hunter transferred to the Illinois conference. 
JOURNAL of the Sixth Annual Session of the Indiana Conference of the Methodist Episcopal Church, at New Albany, Indiana, October 25, 1837.

Wednesday, 9 o'clock a. m., conference met pursuant to appointment and no ${ }^{1}$ one of the bishops being present, on motion by C. W. Ruter, Rev. James Havens was called to the chair and opened the conference by reading a portion of scripture, singing and prayer. The list was called and the following members being present, took their seats: Enoch G. Wood, Rodman Lewis, Joseph Tarkington, James Jones, James Scott, Lemuel L. Reeves, Miles Huffaker, John C. Smith, C. W. Ruter, Allen Wiley, Isaac Owen, Sanford L. Williams, John Kerns, William Shanks, Thomas L. Gunn, James Havens, F. C. Holliday, E. R. Ames, Samuel C. Cooper, W. M. Dailey, Thomas Ray, Enoch Wood, John Miller, John Daniel, John A. Brouse, I. C. Harbin, Aaron Wood, James L. Thompson, Amasa Johnson, Charles M. Holliday, Cornelius Swank, H. S. Talbott, Joseph White, Richard C. Meed, David Stiver, George N. Beswick, Stephen R. Ball, William H. Smith.

On motion, it was resolved that conference elect two secretaries by ballot, and on counting the votes, C. W. Ruter and Edward R. Ames were declared duly elected. Conference then proceeded to elect by ballot, a president pro-tem; James Havens was declared duly elected and accordingly took the chair. After having made a few appropriate remarks conference proceeded to business. On motion, it was resolved that conference hold but one session per day. Resolved, that conference meet at 8 o'clock a. m. and adjourn at 12 o'clock m. A. Wiley, C. W. Ruter, E. R. Ames were nominated and elected a committee to appoint the preachers who shall preach during conference and also to superintend the congregations. William Shanks,

1 Ministers were often detained because of inclement weather, bad roads, poor means of travel, and sickness. 
James Scott and Aaron Wood were elected conference stewards. James L. Thompson, Aaron Wood and John A. Brown were nominated and elected to write the memoirs of the dead. On motion, it was resolved that a committee of one from each district be elected to be denominated the financial committee, and on motion, the Presiding Elder from each of the different districts were elected that committee. On motion, it was resolved that a committee to consist of one preacher in charge from each Presiding Elder's district, be appointed to be denominated the committee on itinerancy. The by-laws of the first session of the Indiana conference were read, and on motion, adopted for the government of the conference during the present session. On motion, it was resolved that a committee of five be appointed to be denominated the committee on university. Resolved that conference adjourn to meet this afternoon at 2 o'clock.

Wednesday, 2 o'clock p. m., conference met pursuant to adjournment and was opened according to rule. Rev. James Havens in the chair, conferen a proceeded to business. Conference took up the first question on the minutes, viz: Who are admitted on trial? Samuel T. Gillet, Isaac Crawford, Thomas F. Spillman, John C. Crouch, were admitted and Henry S. Dane was readmitted. P. Royce, John B. Burt, John Edwards, Miltiades Miller were admitted. Mark Bruffy and Ezra Munson were not admitted, but the Presiding Elder has leave to employ them. The president announced the following names as the committee on itinerancy: James Jones, J. Daniel, Wm. M. Dailey, John Kern, A. Johnson, F. C. Holiday, F. M. Beswick and R. C. Meeks. And C. H. Ruter, S. C. Cooper, A. Wood, I. C. Smith and Wm. Shanks on the university. Conference adjourned.

Thursday, 8 o'clock a. m., conference met pursuant to adjournment and was opened according to rule. 
Brother Havens in the chair, conference proceeded to business. The stewards having spent some time in attending to the pecuniary concerns of the conference and Bishop Soule having arrived, and after making a few appropriate remarks, took the chair. Conference voted to draw on the book concern for four hundred dollars and on the charted fund for eighty-two dollars. One of the book agents from Cincinnati being present read a report containing a statement of the situation of the Western Book Concern, accompanied by an address to the conference. On motion, the college agents were authorized to settle with the trustees for the amount of their salaries. On motion, the conference elected H. S. Talbott, Wm. M. Dailey and John C. Smith on the book committee. The president laid before the conference a communication from the book agents of New York containing an exhibit of the fiscal concerns of that establishment, which was read. An address from the Ohio conference, containing a preamble and resolutions on the subject of proper distribution of the revenues arising from the book concern, which was read, and on motion, referred to a committee consisting of A. Wiley, E. R. Ames, I. A. Brouse, J. L. Thompson and J. Havens.

On motion, Wm. Shanks, C. W. Ruter and James Scott were chosen a committee to estimate the table expenses of the superintendent (R. R. Roberts) residing within the bounds of the conference. Conference resumed the first question on the minutes. D. H. D. Dickerson, Wm. H. McGunnis were admitted. Wm. Knowles was not admitted, but on motion, the Presiding Elder has leave to employ him. Conference adjourned.

Friday, 8 o'clock a. m., conference met pursuant to adjournment and was opened according to rule. Bishop Soule in the chair, conference proceeded to business. The committee to whom was referred the 
communication from the Ohio conference on the subject of funds of the book concern, reported as follows : Having had the subject under consideration, we beg leave to recommend to the conference a concurrence with the resolutions adopted by the Ohio conference, viz: Resolved, that the members of the Indiana annual conference of the M. E. Church disapprove of drawing on the book concern for money to pay the expenses of the delegates to the General Conference or any part thereof; and that we do hereby respectfully request that it may never be done again. Signed,

\section{ALLEN WILEY, Chairman.}

The report having been read, was, on motion, adopted. Conference proceeded to the consideration of the second question on the minutes: Who are admitted into full connection? E. Patrick, Isaac McElroy, I. W. Sullivan, I. I. Lewis, Daniel Demott, Wm. B. Ross, I. M. Stollard, B. T. Griffith, W. W. Hibbon, C. B. Jones, Erastus Kellogg having been previously examined by the commitiee appointed for that purpose, were called forward and questioned, and advised by the bishop as the discipline directs, after which their characters were examined, admitted into full connection and elected to Deacons Orders; except I. J. Lewis, who was not admitted. Bros. Patrick, Sullivan, Demott, Jones and Kellog were not elected, having been previously ordained as local preachers. Conference proceeded to the consideration of the sixth question on the minutes, viz: Who have been elected and ordained elders this year? I. A. Brouse, Stephen Ball, Hiram Griggs, James Harrison, I. C. Harlin, Lemuel Reeves were severally examined and elected to Elders Orders. The case of R. C. Meed was laid over. Conference resumed the consideration of the first question on the minutes and Joseph S. Barwick, Jacob Myers, Jacob Miller, I. Harrymen were admitted and Cyrus Nutt was not admitted. Benjamin Barnes, I. V. Watson, 
Eli P. Farmer, L. D. Smith, Jonas L. Belott, Thomas Poyner, Wm. Forbs were admitted. I. Cooper and Daniel Dillon were not admitted, but on motion, the Presiding Elder has leave to employ them. On motion, the conference altered the time of their morning meeting from 8 to $8: 30$ a. $m$. At the request of $R$. C. Meed his case was referred to a committee of three, viz: H. Talbott, W. V. Daniel and Thomas Ray. Conference adjourned.

Saturday, 8:30 o'clock a. m., conference met pursuant to adjournment and was opened according to rule. Bishop Soule in the chair, conference proceeded to business. The committee in the case of R. C. Meek presented their report, which after some discussion, was not accepted by the conference. Brother Meek made some statements relative to his case and retired. When his character passed he was elected to Elders Orders. Conference took up the consideration of the case of local preachers recommended for Deacon's Orders. Hosier I. Durbin, recommended from Madison district, was elected. John C. Crouch and Peter Weaver were not elected.

The committee on the university presented their report, which was read and, on motion, said report was laid on the table to be made the order of the day for Monday next. Wm. Pennington, from Charlestown district; Thomas W. Sergeant and John Hardy, from Indianapolis district; John Mcrea, John Evans, Thomas Guynn, from Bloomington district; Francis V. McGee, D. Dickinson, Wm. Bratton, I. M. Barnett, from Crawfordsville district; C. C. Beeks, Elijah Harbour and Charles Lumpton, from Centerville district, were all elected to the office of deacons as recommended for Elders Orders. John Linville, from Indianapolis district; Vance Jones, from Bloomington district; I. L. Belotte, from Crawfordsville district; John Hughs, from Charlestown district, were severally elected to 
that said office. Conference resumed the consideration of the third question, viz: Who are admitted into full connection? John Bayless was examined by the Bishop before the conference, and after his character was examined, was admitted into full connection and was elected to deacon's orders. Davis Stucker was also examined, but did not pass; on motion, the Presiding Elder has permission to employ him. On motion, it was resolved that when conference adjourns, we meet again this afternoon at 2 o'clock. On motion, it was resolved that conference will comply with the request of the Rev. Mr. Ranson, agent of the A. B. Society, and will listen to his remarks on Monday morning. Conference adjourned.

Saturday, 2 o'clock p. m., conference met pursuant to adjournment and was opened according to rule. Bishop Roberts in the chair, conference proceeded to business in consideration of the first question on the minutes, viz: Who are admitted on trial? Wm. Hulbert, Francis H. Cary, Thomas Owen and Emmons Rutledge were admitted on trial but Thomas Brown was not admitted. Henry Vanorder and Robert Burns were admitted. Conference proceeded to the consideration of the second question of the minutes: Who remain on trial? The characters of Wm. H. Good, Ezra L. Kemp, John H. Bruce, John M. Cole, Wm. Trailey, J. B. Nershon, John F. Trouslow, A. Robinson and Wade Poisy were severally examined and continued on trial. R. R. Burts was discontinued. Conference adjourned.

Monday, 8:30 o'clock a. m., conference met pursuant to adjournment and was opened according to rule. Bishop Soule in the chair, conference proceeded to business. The Rev. Mr. Ransom, state agent for the American Bible Society, was introduced to the conference, who delivered a short address on the subject of his agency after which, on motion, a committee of 
three were appointed to consider the subject and prepare it for the action of the conference. Wm. V. Daniel, James Havens and Wm. Shanks were appointed said committee. The following resolution was then introduced, read, and on motion, adopted, viz: Resolved by the Indiana annual conference in conference assembled, that the first Thursday in December, next, be set apart as a day of thanksgiving to Almighty God for the general health of our citizens and abundant fruits of the earth the present year; and that the governor of the state be respectfully requested to issue his proclamation requesting the citizens generally to unite in offering, on that day especially, ascriptions of praise to the rich donor of all our blessings. C. W. Ruter and E. R. Ames. Conference then resumed the consideration of the second question on the minutes: Who are continued on trial? The characters of Isaac Kelso, Frances M. Richmond, G. M. Boyd, H. B. Beers, Jacob Colderidge, C. C. Beeks, Philip May and John Sewell were examined and continued on trial. James D. Sanford, Wm. D. Cox, Isreal Welch, John Sinclair and Soloman Miller were discontinued. Conference then took up the consideration of the fourth question on trie minutes: Who are the deacons? The characters of F. C. Holliday, Thomas C. Gunn, Isaac Owen, Thos. Fartlett and S. S. Williams were severally examined and passed. Thos. S. Gunn asked and obtained a location. The following resolutions were then introduced, read, and on motion, adopted, viz: Whereas, a treatise on Roman Catholicism exposing the errors and hurtful tendencies of that system, is much needed in the Mississippi Valley; and whereas, the Rev. Charles Elliott is now composing a book on that subject and with such aims; therefore, be it resolved by the Indiana annual conference, that the book agents of Cincinnati be requested with the approbation of the Western Book committee to secure the copy right of said work and pub- 
lish it for the M. E. Church. Resolved, secondly, that it be recommended to the book agents at Cincinnati with the approbation of the Western Book Committee to secure the copy right of a book entitled, "History of the Wyandott Mission," now being written by Rev. James B. Finley and publish it for the Methodist Episcopal Church. Signed, Allen Wiley, E. R. Ames; New Albany, Ia., October 30, 1837. The conference then proceeded to the examination of the characters of elders. E. G. Wood, Rodman Lewis, Joseph Tarkington, Lewis Hurlburt, James Jones, Boyd Phelps, Geo. K. Hester, John C. Smith, Miles Huffaker, C. W. Ruter, A. Wiley, James T. Robe, John Kerns, Wm. Shanks, W. V. Daniels, James Haven, A. Eddy, E. Whitten, E. R. Ames, Samuel C. Cooper, Wm. C. Dailey, C. Bonner, Thomas Ray, Enoch Wood, John Miller, John Daniels, Aaron Wood, James L. Thompson, Amasa Johnson, Thomas Brown, Charles Holliday, Cornelius Swank, Ancil Beach, H. L. Talbott, H. Vedenburgh, Joseph White, R. Hargrave, R. S. Robinson, B. Weslake, David Stiver, George M. Beswick, W. H. Smith, Asa Beck and John Pitchey were severally examined and passed. Rodman Lewis, Joseph Tarkington, James L. Thompson, Wm. H. Smith and John Ritchey were superannuated. Asa Beck was reported as effective and Wm. Shanks superannerary. Conference adjourned.

Tuesday, 8:30 o'clock a. m., conference met pursuant to adjournment and was opened according to rule. Bishop Soule in the chair, conference proceeded to business. The stewards presented their report, which was read, and on motion, adopted. The committee appointed to estimate the table expenses of Bishop Roberts, presented their report, which was read, and on motion, adopted, viz: three hundred dollars. ${ }^{1}$ The committee on the Bible Society presented their report

1 See Minutes for 1832 . 
embodying several resolutions, which was read, amended, and on motion, adopted, that the presiding elder of Charlestown district and the stationed preacher in New Albany be appointed to address a meeting which may be appointed on that subject. Conference proceeded to take the number of Sabbath schools, etc. Richard C. Meek asked and obtained a location. On motion, it was resolved that conference take up that part of the report of the committee on the university which relates to the appointment of agents. Resolved, that for the more effectual and speedy endowment of the university it is desirable that four special agents be appointed for the ensuing year. On motion, it was resolved that we adjourn to meet this afternoon at 2 o'clock.

Tuesday, 2 o'clock p. m., conference met pursuant to adjournment and was opened according to rule, Bishop Roberts in the chair. Conference then proceeded to elect four agents for the Indiana Asbury University and on counting the votes, Wm. Shanks, S. C. Cooper, Wm. M. Dailey and John Brouse were declared duly elected. Conference proceeded to fix the place of its next session, and on counting the votes it was found that Rockville, Parke county, ndiana, had a majority to which place conference was appointed to meet on the 17th of October, 1838. Conference proceeded to elect an agent for the Preacher's Aid Society and on counting the votes, James Havens was declared duly elected. On motion, conference took up that part of the report of the committee on the university, which relates to the filling of vacancies in the board of trustees. Henry Havens was elected to fill the vacancy occasioned by the resigning of T. A. Howard, and James Talbott was elected to fill the vacancy occasioned by the resignation of John W. Osborn. A committee of three, consisting of E. R. Ames, Samuel C. Cooper and James Havens, was appointed to nominate nine 
persons as a board of visitors to the I. A. University. On motion, it was resolved that the agent, C. W. Ruter, appointed by this conference to collect the legacy of James Paxton, deceased, be directed to pay it over with the proceeds thereof to C. I. Hand for the benefit of the Preacher's Aid Society. On motion, the vote by which James L. Thompson was superannuated, was reconsidered. On motion, the vote taken in the case of Wm. Knowles, was reconsidered and he was admitted on trial. On motion, Aaron Wood, James Havens and Richard Hargrave were appointed a committee to divide the conference into four districts, assigning to each college agent, his respective field of labor. On motion, John Smith, John S. Bayless and James Havens were nominated and elected a committee to take into consideration the claims of a temperance paper recently established in $^{3}$ Indianapolis and report to this conference. Conference adjourned.

Wednesday, 8:30 o'clock a. m., conference met pursuant to adjournment and was opened according to rule. Bishop Soule in the chair, conference proceeded to business. The committee appointed to nominate a Board of Visitors of the I. A. University, reported Allen Wiley, James Havens, H. S. Talbott, Augustus Eddy, I. L. Thompson, S. C. Cooper, William Shanks, William M. Dailey and John Brouse, which nomination was confirmed by the conference. The committee appointed to take into consideration the claims of a temperance paper presented their report "That in their opinion a paper of that character might greatly subserve the cause of temperance in this state, therefore, resolved that this conference will give their united influence for the wider circulation and more permanent usefulness of this publication. Resolved, that this report be forwarded to the editor (John W. Osborn) of

3 For many years the only temperance paper in the state was published at Greencastle. 
said paper for publication. J. C. Smith, chairman." The committee appointed to write the memoirs of the dead presented their report containing the memoirs of the Rev. John Ray and Rev. Smith S. Robinson, which was read and, on motion, adopted. The book committee presented their report which was read and adopted. The committee appointed to attend the examination of the New Albany Seminary presented their report which was read and, on motion, adopted. On motion, a committee of three were appointed to attend the next annual examination of said seminary. The presiding elder of Charlestown district and the preachers of New Albany and Jeffersonville were appointed that committee. The committee appointed to district the conference and assign to each college agent their fields of labor, presented their report as follows: William Shanks, Charlestown district and that part of Vincennes district south of White river. Wm. M. Dailey that part of Vincennes district north of White river and the Bloomington and Madison districts. S. C. Cooper, the town of Indianapolis and the Crawfordsville and Laporte districts. John A. Brouse, Indianapolis and Centerville districts excepting the town of Indianapolis. Aaron Wood, chairman. On motion, the vote taken in the case of Mark Bruffy was reconsidered and he was admitted on trial. The report of the committee on the I. A. University was taken up and read, and a motion made that the conference advise the trustees to obtain a loan of fifty thousand dollars if practicable for the benefit of the institution, which after some discussion, the vote was taken but was decided in the negative. A motion was made that the conference pledge themselves to use their best efforts to send as many students as they can to the I. A. University during the coming year, and to procure as many books as possible by donation for the library, which after some discussion, was decided in the negative. On motion, 
it was resolved that the members of this conference be requested to use their influence to promote the interest of the university and especialiy in the collection of books. On motion, it was resolved that a committee of three be appointed to memorialize Congress of the United States asking a donation of land for the benefit of the university. Allen Wiley, I. C. Smith and Aaron Wood were appointed that committee. On motion, it was resolved that the joint board of the trustees and visitors be requested to memorialize Indiana Legislature praying that body to memorialize Congress in behalf of the I. A. University praying that body to make a donation of land to said university. A motion was made to adopt the report which was carried in the affirmative. And a committee of three was appointed to prepare such parts of the report as they deemed expedient for publication. Secretary of the conference and the stationary preachers at New Albany and $\mathrm{Je}_{-}^{-}$ fersonville to be that committee. On motion, it was resolved that the secretary of the conference furnish the board of trustees with all necessary extracts from the journal for their information. James Havens presented the papers in the case of Fletcher Tivis, an expelled local preacher on Rushville circuit, who appealed to this conference, but he being not present to prosecute the appeal, the conference, on motion, dismissed said appeal. Conference adjourned to meet this afternoon at 2 o'clock.

Wednesday, 2 o'clock p. m., conference met pursuant to adjournment and was opened according to rule. Bishop Soule in the chair, conference proceeded to business. The committee appointed to memorialize Congress in behalf of the I. A. University, presented their report which was read, and, on motion, was directed to be placed in the hands of the preacher who may be appointed to Indianapolis station that he may enlarge and prepare it suitably, and forward it to some 
member of Congress as soon as it may be practicable. On motion, it was resolved that a vote of thanks be tendered to the citizens of this town for their kindness to the preachers during the present session of conference. On motion, it was resolved that a vote of thanks be tendered to the several denominations of christians in this town for the use of their meeting houses during the present session of conference. On motion, it was resolved that when conference adjourns it meets at 6:30 o'clock in the Methodist Church in this town. Conference adjourned.

Wednesday, $6: 30$ o'clock p. m., conference met pursuant to adjournment and was opened according to rule. Bishop Soule in the chair. After an appropriate address by the superintendent, on motion, the appointments of the preachers were read out and conference adjourned to meet in Rockville, Parke county, Indiana, on the 17th of October, 1838.
C. W. RUTER.
J. SOULE.

APPOINTMENTS FOR 1837.

Madison District.

Enoch G. Wood, Presiding Elder.

Madison-William B. Ross.

Vevay-Lewis Hurlbert, Isaac Crawford.

Rising Sun-Fernandes C. Holliday.

Lawrenceburg-James Jones, Samuel T. Gillet, Silas Rawson.

Brookville-James T. Robe, Henry S. Dane.

Greensburg-Charles Bonner, Amos Bussey.

Versailles-Thomas F. Spillman.

Vernon-Miles Huffaker.

Sand Creek Mission-Pleasant Royce.

Charlestown District.

Calvin W. Ruter, Presiding Elder. 
New Albany-Aaron Wood.

William H. Good, Principal of the New Albany Seminary.

Corydon-Isaac Owen, Jacob Myers.

Greenville-Benjamin T. Griffith.

Paoli-Jacob M. Stallard.

Salem-Ebenezer Patrick, William Fraley.

Brownstown-Emmons Rutledge.

Lexington-George K. Hester.

Charlestown-William V. Daniel, Jesse C. Harbin. Jeffersonville-John Kearnes.

\section{Indianapolis District.}

Augustus Eddy, Presiding Elder. Indianapolis-John C. Smith. Indianapolis Circuit-John Edwards. Shelbyville-John W. Sullivan, John B. Birt. Rushville-John F. Truslow, Joseph H. Harryman. Noblesville-Miltiades Miller.

Danville-Asa Beck, John Newell.

Franklin-William W. Hibben.

Columbus-James V. Watson, Constant B. Jones. Mooresville-Hiram Greggs.

Bloomington District.

Henry S. Talbott, Presiding Elder. Bloomington-Amasa Johnson.

Springville-Philip May.

Bedford-Ezra L. Kemp.

Greencastle-James L. Thompson. Greencastle Circuit_Jonas L. Belotte.

Putnamville-Thomas Ray.

Spencer-William Meginnis.

Brown Mission-Eli P. Farmer.

Rockville-Charles M. Holliday.

Russelville-Enoch Wood. 
Vincennes District.

John Miller, Presiding Elder.

Vincennes-John S. Bayless.

Terre Haute-John Daniel.

Terre Haute Circuit-Daniel Demott, Daniel H. Dickerson.

Carlisle-Thomas Bartlett, William J. Forbes.

Washington-Isaac McElroy.

Princeton-William Knowles.

Mount Vernon-Lemuel M. Reeves, Joseph S. Barwick.

Boonville-Anthony F. Robinson.

Rome-Jacob Miller.

Knox Mission-John M. Cole.

\section{Crawfordsville District.}

Allen Wiley, Presiding Elder.

Crawfordsville-Benjamin N. Barnes.

Crawfordsville Circuit_Joseph White.

Cole Creek-Thomas Poyner.

Covington-Cornelius Swank, Colbreth Hall.

Pine Creek-Ancil Beach.

Lafayette-Lorenzo D. Smith.

Delphi-Burroughs Westlake.

Monticello-John H. Bruce.

Dayton-Halkaliah Vredenberg.

Frankfort-Thomas Brown.

Logansport-Jared B. Mershon.

\section{Laporte District.}

Richard Hargrave, Presiding Elder.

Laporte-Boyd Phelps, H. Vanorder.

South Bend and Mishawaka-Richard S. Robinson.

Niles-James S. Harrison, Sanford S. Williams.

Kalamazoo-Erastus Kellog, Jacob Colclazer.

St. Joseph-William Todd. 
Elkhart-Thomas P. McCool.

Plymouth Mission-Thomas P. Owen.

Lagrange-George M. Boyd.

Fort Wayne-Stephen R. Ball.

Warsaw Mission-William Hulbert.

Deep River Mission-Hawley B. Beers.

\section{Centerville District.}

David Stiver, Presiding Elder.

Centerville-Elijah Whitten, Greenberry C. Beeks.

Winchester-Wade Posey, Isaac Kelso.

Newcastle-Alexander K. Miller.

Munceytown-Robert Burns, Francis H. Carey.

Mississinewa-George W. Bowers.

Connersville-James Scott, John Kiger.

Liberty-George M. Beswick, John Hasty.

Pendleton-Francis M. Richmond, Mark Bruffy.

William Shanks, Samuel C. Cooper, William M. Dailey and John A. Brouse, agents for the Indiana Asbury University.

James Havens, agent for the Preachers' Aid Society.

Edward R. Ames, transferred to the Missouri conference and stationed at St. Louis.

JOURNAL of the Seventh Indiana Annual Conference held in Rockville, Parke County, Indiana, October $17,1838$.

Wednesday morning, 9 o'clock a. m., conference met according to appointment and was opened by Bishop Soule by reading a portion of the Holy Scripture, singing and prayer.

The list was called and the following members being present, took their seats: E. G. Wood, H. Vredenburgh, E. Patrick, H. Hargrave, Wm. V. Daniel, James S. Harrison, F. C. Holliday, Erastus Kellog, John C. Smith, Elijah Whitten, James Jones, James Scott, Wm. 
W. Hibben, Geo. M. Beswick, C. B. Jones, S. C. Cooper, Amasa Johnson, Wm. M. Dailey, James L. Thompson, John A. Bruose, H. L. Dane, James Havens, E. P. Farmer, J. Tarkington, Miles Huffaker, William Smith, John Miller, J. M. Stallard, C. W. Ruter, Lewis Hulbert, Daniel Demott, I. C. Harbin, Thomas Bartlett, A. Eddy, Allen Wiley, John W. Sullivan, Joseph White, Asa Beck, Ancil Beach, C. Bonnet, H. S. Talbott, James T. Robe, I. S. Belotte, Thomas Ray, C. M. Holliday, Enoch Wood, John S. Bayless, John Daniel, Aaron Wood, I. McEllroy, Isaac Owen, Cornelius Sevant, B. F. Griffith, Thomas I. Brown, Richard S. Robinson, S. S. Williams, David Stiver.

Bishop Soule in the chair, conference proceeded to business. John C. Smith was elected secretary and C. W. Ruter assistant secretary. Conference resolved to hold but one session per day. Resolved, that conference meet at 8:30 o'clock a. m. and adjourn at 12:30 p. m. H. C. Talbott, Samuel C. Cooper and C. M. Holliday were appointed a committee to superintend the congregations, and to appoint ministers to preach during the present session. Conference proceeded to elect the stewards, and on counting the votes, Samuel C. Cooper, James Scott and E. Patrick were declared duly elected.

Allen Wiley, Wm. M. Dailey and Augustus Eddy were appointed a committee to write the memoirs of the dead. The president presented a communication from the book agents of New York containing an exhibit of the condition of the book concern, which was referred to the book committee, viz: John A. Bruose, A. Wood and James T. Robe.

Conference then proceeded to consider the first question on the minutes, viz: Who are admitted on trial? Melville Wiley, Seth Smith, John Talbott, John L. Kelly, Hezekiah Smith, Lucian W. Berry, Cyrus Nutt, Lewis L. Allen, Henry B. Harrold, William F. 
Wheeler, George W. Stafford and William Wilson were admitted. Isaac Welsh was not admitted.

Conference adjourned.

Thursday, 8:30 o'clock a. m., conference met pursuant to adjournment and was opened according to rule. First Jcurnal read and approved, Bishop Soule in the chair, conference proceeded to business. The vote by which $\mathrm{C}$. W. Ruter was elected assistant secretary was reconsidered, ${ }^{1}$ and John Daniel was elected in his place. Resolved that the by-laws of the last session be adopted for the government of this session. Brother Wright, a book agent from Cincinnati, presented a communication to conference exhibiting the condition of that establishment, accompanied with an address. The steward then spent some time in attending to the pecuniary matters of the conference. A communication was made to conference from Brother Phelps containing the credentials of Gilbert Rose, formerly a local deacon in conference. Conference voted to draw on the book concern for four hundred dollars, and on the chartered fund for ninety dollars. A communication received from the managers of the Preachers' Aid Society, informing the conference that they were permitted to draw on that institution for two hundred and fifty dollars.

Conference then resumed the consideration of the first question on the minutes and Wm. H. Sampson, Francis A. Conwell and John Hull were admitted. And John Urcanbrack was readmitted, but Jacob Jameson was not admitted. The Presiding Elder has liberty to employ him if expedient. Moved that Isaac Welsh may be employed by the Presiding Elder if necessary. John Kesling was not admitted, but the Presiding Elder has liberty to employ him. L. Wiley was admitted, but

1 Upon being elected assistant secretary, C. W. Ruter expressed his desire to resign on account of ill health, wherewith the rote was reconsidered and John Daniel was elected in his place. 
Joseph Ockerman was not admitted. Y. Games and Thomas S. Gunn were readmitted. John P. Sinclair was not admitted. James Hill, George Havens, E. Vanschorack, William Campbell, Josiah I. Cooper, Ebenezer Arnold and John B. Jenkins were admitted. On motion, resolved that conference adjourn to meet at 3 o'clock p. m.

Thursday, 3 o'clock p. m., conference met pursuant to adjournment and was opened according to rule. Journals read and corrected and approved. Bishop Soule in the chair, conference proceeded to business. On motion, resolved that the Presiding Elder, in whose district I. P. Sinclair may reside, have liberty to employ him if necessary. Conference resumed the consideration of the first question on the minutes, and Daniel K. Stright, Landy Havens, E. S. Sheffield, Joseph Byron, Samuel K. Young, George Stanley, Henry Worthington and Franklin Gage were admitted. E. Lank was not admitted. Thomas Hedrick, Daniel Dilling and Frederick Long were not admitted. But permission was granted to the Presiding Elder in whose districts they may reside to employ them if they think proper, also to employ Eli Rogers if his labors shoulds be required. Wm. C. H. Bliss was not admitted nor William Weslake readmitted, but may be employed by his Presiding Elder should his labors be required. Conference adjourned.

Friday, 8:30 o'clock a. m., conference met pursuant to adjournment and was opened according to rule. Bishop Soule in the chair, conference proceeded to business. The report of the trustees of the Indiana Asbury University was presented to conference, which referred to a committee consisting of Samuel C. Cooper, A. Eddy, C. W. Ruter, A. Wiley and James L. Thompson.

Conference then proceeded to the consideration of the third question on the minutes, viz: Who are ad- 
mitted into full connection? Wm. H. Good, E. L. Kemp, John H. Bruce, Wm. Frailey, I. B. Mershon, A. F. Robinson, Isaac Kelso, F. M. Richmond, George M. Boyd, Jacob Colclazier, G. C. Becks and Philip May, having been previously examined by the committee, were called forward and questioned and advised by the bishop as the discipline directs, after which their characters were severally examined, and they were all admitted, and elected to deacon orders, except F. Richmond, G. C. Becks and P. May, who were elected to elder's orders, having been previously ordained deacons.

Thos. P. McCool, John Newell and John Hasty were discontinued at their own request. John F. Truslow was discontinued in consequence of ill health. C. Hall and John M. Cole were discontinued. Wade Poesy, H. B. Beets were continued on trial.

A motion, Resolved that the president revise the course of study for the conference. The report of the Board of Visitors to the Indiana Asbury University was presented to conference, and on motion, was referred to the committee, to whom was referred the report of the Board of Trustees of said university. Conference then proceeded to the consideration of the second question on the minutes: Who remain on trial? Characters of Samuel Gillet, Isaac Crawford, Thomas S. Spillman, I. Royce, John B. Burt, John Edwards, M. Miller, Daniel H. Dickinson, Wm. Meggins, Joseph S. Barwick, Jacob Myers, Jacob Miller, Wm. I. Forbes, F. H. Casey, Thomas P. Owen, Emmons Rutledge, John Kiger, George W. Bowers, Alexander L. Miller, Amos Bussey, Silas Rawson and William Knowles were severally examined and passed. John W. Weekly was, by a transfer from Ohio conference, received on trial. Joseph H. Hannaman, Thomas Poyner, Wm. Hulburt and Mark Bruffy were discontinued. On motion, conference adjourned to meet at three o'clock p. m. 
Friday, 3 o'clock p. m., conference met pursuant to adjournment and was opened according to rule. Journal read and approved, Bishop Soule in the chair, conference proceeded to business.

The committee to whom was referred the report of the Board of Trustees of the Indiana Asbury University presented their report, which was read and adopted, and on motion, ordered to be spread on the Journal as follows:

The committee to whom were referred the reports of the boards of trustees and visitors of the Indiana Asbury University have had the same under consideration, and take leave to report the following resolutions :

Resolved, 1st., That the thanks of this conference be presented to the board of trustees for their regular and prudent management of the institution over which they have presided.

Resolved, 2nd., That the president of the conference be requested to appoint two agents from the conference to operate in behalf of said university. ${ }^{2}$

Resolved, 3rd, That we deem it inexpedient at this time to send an agent out of our state to solicit funds for our university.

...- At the last annull Conference I was aphointed one of the agents for the Indiana Aslury Iniversity. I commenced my work as an agent in Intianapolis when I spent two or three weeks during the session of the Legislature and did something rery handsome among the members. My next point was spencer, a little town of about ton population and here I obtained subscripd tions to the amount of $\$ 600$. From here I proceeded to Rockville and from there to Crawfordsville and on to Terre Haute. From thence I came to Vincennes. To the astonishment of all I procured in this place funds to the amount of $\$ 1,020$. My next place was Washington, a little place of about 500 population. From common fame I thought it rather a gloomy outlook for an agent. but to their honor I procured notes to the amomt of $\$ 700$. I am now on my waly to Carlisle, March 1, 1835.

Yours,"

WILLIAII M. DAILY. 
Resolved, 4th, That the trustees are hereby respectfully requested not to appropriate any part of the funds raised for a permanent endowment, for any other purpose than the payment of salaries of professors, agents and the purchase of a library and apparatus for the institution.

Resolved, 5th, That I. M. Allison be appointed a trustee to fill the vacancy occasioned by the death of James Montgomery, and that Alexander T. Farrow, William Crumpton, James Nosler and John Wilkins be appointed to fill the places of Robert R. Roberts, S. E. Leonard, Jacob Hays and Martin M. Ray, whose seats have been declared vacant.

Resolved, 6th, That the secretary of the conference be requested to furnish a copy of report of the board of visitors for publication in the Western Christian Advocate. Also a copy of these resolutions to the president of the board of trustees of the Indiana Asbury University -all of which is respectfully submitted.

\section{S. C. COOPER, Chairman.}

Conference then proceeded to the consideration of the fourth question on the minutes, viz.: Who are the deacons? The characters of Isaac McEllroy, Jacob M. Stallard, Benjamin F. Griffith, John F. Bayless and William D. Rops were severally examined and passed. $\mathrm{Wm}$. B. Ross was located at his own request. Conference proceeded to the consideration of the fifth question on the minutes, viz.: Who have been elected and ordained elders? And that characters of F. C. Holliday, Isaac Owen, Thomas Bartlett, Sanford S. Williams, I. W. Sullivan, Daniel Demott, W. W. Hibben, C. B. Jones, Erastus Kellog and Henry Dane were severally examined and elected to Elders' Orders. James V. Watson was not elected, and on motion changed to a superannuated relation. Conference adjourned.

Saturday, one-half past eight o'clock a. m. Conference met pursuant to adjournment and was opened 
according to rule. Journal read and approved. Bishop Soule in the chair. Conference proceeded to business. On motion, resolved, that Brother Wiley be requested to preach the funeral sermon of Brother Bames, deceased, on Sabbath at three o'clock p. m. S. C. Cooper, A. Eddy and H. S. Talbott were nominated a committee to estimate the table expenses of Bishop Roberts.

Conference proceeded to take up the case of local preachers recommended for Deacons' Orders. And Amos Bussey, Isaac Crawford, David Stucker, Miltiades Miller, John A. Spear, Jacob L. Pfoff, Hezikiah Smith, John Newell, E. Van Schoick, William McGimes, John P. Sinclair, Henry Behassol, Henry D. Lee, William Webb, Thomas C. Griffith, John Robinson, Josiah I. Cooper, William H. Sampson, William C. H. Bliss, John Martin, Matthias Stover, C. Hall, James Taylor and John Crouch were elected to that office. John G. Gallaspy, R. K. McAllum, Hurbert P. Debuler, Lane W. Posey, Eli Rogers, Samuel Smith and G. Shannahan, were not elected. On motion the vote by which H. P. Debruler was elected to Deacons' Orders, was reconsidered, and after some debate on the vote, was taken and lost.

Conference then took up the case of local deacons recommended to Elders' Orders. Alfred I. Colton, Nathan Fairchild and John Decker were elected to that office.

The following preamble and resolution were read and adopted, to-wit:

Whereas, There has been a very general neglect in receiving members into full connection into the church, and,

Whereas, This neglect has been in consequence of the careless manner pursued in recording the names of probationers; therefore,

Resolved, That each preacher of this conference appointed in charge of a circuit or station, in going to 
his charge, shall cause a church register ${ }^{3}$ provided in which shall be inserted the names of all members and probationers, stating clearly the dates when the probationers joined on trial, and also who shall cease to be members in the circuit or station, whether by death, removal, expulsion or withdrawal, and the discontinuance of all probationers.

A. WILEY,

C. W. RUTER.

The following resolution was read and adopted by motion:

Resolved, That the Presiding Elder be requested to inquire at their quarterly meetings if the preachers in charge have attended to the duties enjoined in the foregoing resolution.

\section{JAMES L. THOMPSON,} SAMUEL C. COOPER.

Whereupon, the following resolution was unanimously adopted:

Resolved, That we have no discretion in admitting persons to our love and class meetings (not members of our church) oftener than discipline permits.

\section{A. EDDY, W. W. HIBBEN.}

A communication was received from Amos Spark relative to his location by this conference and being read a motion was made to readmit him which was lost. A motion was made to reconsider the vote by which Clifford Shannahan was elected to Deacons' Orders, which failed. On motion, resolved, that the secretary of this conference be requested to furnish each Presiding Elder a copy of the resolution requiring each

3 The need of such a register was very much in evidence. At this time there were no public places for meeting, neither was there any scheduled time for meeting. The circuitous route over which the circuit rider had to travel together with the long interrals in which no service was held, made it almost impossible for him to remember the members of his congregation unless some written accounts were kept. 
preacher in charge to keep a church record. Conference adjourned.

Monday, one-half pas ¿̀ eight o'clock a. m. Conference met pursuant to adjournment, and was opened according to rule. Jounal ind and approved. Bishop Soule in the chair. Conference proceeded to business. The members in society, after which conference proceeded to fix, by ballot, its next annual session, and on counting the votes, Lawrenceburgh was found to have a majority of votes and was declared the place of holding its next annual session of conference.

The committee appointed to estimate the table expenses of Bishop Roberts reported that they had estimated the same at three hundred dollars.

The stewards presented their report which was read, amended and on motion adopted. On motion, resolved, that the superintendent be requested to appoint an agent for the Preachers' Aid Society the present year.

The following resolution was offered, and on motion adopted :

Resolved, That the avails of the Preachers' Aid Society be appropriated to the most necessitous cases (by the stewards) according to the provisions of the constitution of said society. And, on motion,

Resolved, That the Presiding Elders be requested to report to the stewards the most necessitous cases in their bounds. Conference then went into the examination of the characters of Elders, and on motion resolved to dispense with the usual formality of their retiring from the room during the examination of their character, the Presiding Elders and those against whom charges may be brought, excepted. The name of E. G. Wood was called and a charge was preferred against him by Miles Huffaker for an improper discharge of his duties of and his office as a Presiding Elder. The specifications in the charge having been (13) 
read, and plead and implied by the parties, they retired, and conference passed the following resolutions:

Resolved, That in the opinion of this conference, the 1st, 2d, 3rd and 4th specifications in the charge are sustained by the evidence in the case.

Resolved, Therefore, that in the opinion of this conference, the charge preferred against E. G. Wood is sustained.

Resolved, That in the opinion of this conference Brother Wood did not intentionally err in the discharge of the duties of his office. Conference adjourned.

Tuesday, one-half past eight o'clock a. m. Conference met pursuant to adjournment and was opened according to rule. Journal read and approved, conIerence proceeded to business. Bishop Soule in the chair.

On motion, the vote by which the report of the stewards was accepted was reconsidered, and on motion recommitted for amendment. The stewards then presented their report as amended which was read and on motion adopted.

The stewards also presented their report on the avails of the Preachers' Aid Society, which was read, and, on motion, recommitted for amendment. The report was then presented as amended and was not accepted.

A motion was made to refund the avails of the Preachers' Aid Society which was lost, and on motion was recommitted. Conference then resumed the examination of the characters of elders, and E. G. Wood, Lewis Hulbert, James Jones, James T. Robe, Charles Bonner, Miles Huffaker, C. W. Ruter, Aaron Wood, Ebenezer Patrick, G. K. Hester, William V. Daniel, Jesse C. Harbin, John Kerns, Augustus Eddy, J. C. Smith, Asa Beck, Henry S. Talbott, Amasa Johnson, E. P. Farmer, James L. Thompson, Thomas Ray, C. 
M. Holliday, Enoch Wood, John Miller, John Daniel, C. M. Reeves, A. Wiley, Joseph White, Cornelius Swank, A. Beach, B. Westlake, L. D. Smith, H. Vredenburgh, T. I. Brown, Richard Hargrave, Boyd Phelps, Richard S. Robinson, Stephen R. Ball, David Stiver, Elijah Whitten, James Scott, Robert Burns, G. M. Beswick, William Shanks, S. C. Cooper, William M. Daily, J. A. Brouse, James Havens, Rodman Lewis, Joseph Tarkington, William H. Smith, John Ritchey, James S. Harrison, William Todd and Henry Vanorder were severally examined and passed. John Kerns, Asa Beck, Robert Burns, William Shanks and John Ritchey were superannuated. Boyd Phelps, S. R. Ball and $H$. Vanorder were located at their own request. The relation of Rodman Lewis, Joseph Tarkington and William H. Smith was changed from superannuated to effective. Hiram Griggs withdrawn.

Conference then resumed the consideration of the first question on the minutes, and James Crawford was admitted. Obadiah Johnson, recommended from Ohio conference, was not admitted. Conference adjourned to meet at three o'clock p. m.

Tuesday, three o'clock p. m. Conference met pursuant to adjournment and was opened according to rule. Journal read and approved. Bishop Soule in the chair. Conference proceeded to business.

The stewards presented their report on the avails of the Preachers' Aid Society, which was read, and, on motion, adopted. The committee on the Book Concern presented their report which was read and adopted. John A. Decker was recommended for readmission but was not admitted. On motion, the Presiding Elder, in whose district W. C. H. Bliss and E. Lank may reside, were permitted to employ them should their services be needed.

The committee on memoirs presented their report containing the memoir of Benjamin N. Bains which 
was read and accepted. The committee on the New Albany Seminary presented their report which was read and accepted. Conference then went into the election of a board of visitors to the Indiana Asbury University which shall consist of nine, and on counting the votes the following persons were found to be elected: A. Wiley, C. W. Ruter, A. Eddy, S. C. Cooper, E. R. Ames, I. C. Smith, H. S. Talbott, James Havens and James L. Thompson.

The following resolution was offered and adopted, viz. :

Resolved, That the visitors elected by the conference be and are hereby required so to arrange their work in their respective fields of labor so as to enable them to attend the semi-annual meetings of the board of visitor.

S. C. COOPER,

C. W. RUTER.

The following resolutions were offered and on motion adopted:

Resolved, That each member of this conference or preacher on trial who shall raise fifty dollars for the Indiana Asbury University shall be entitled to a certificate of scholarship for three years, or six years for one hundred dollars.

S. C. COOPER,

C. W. RUTER.

Resolved, 2nd, That in the opinion of this conference it would be expedient for the trustees of the Indiana Asbury University to instruct their agents to sell certificates of perpetual scholarship for five hundred dollars each.

C. W. RUTER,

H. S. TALBOTT.

Resolved, 3rd, That each and every preacher in this conference who shall raise five hundred dollars or more within five years, for the endowment of a professorship in the Indiana Asbury University (regu- 
larly appointed agents accepted) shall be entitled to a certificate of a perpetual scholarsinip.
C. W. RUTER,
H. S. TALBOTT.

On motion, resolved, that the Presiding Elder, in charge of the Charleston District, and the preachers in charge of the New Albany and Jeffersonville Stations be a board of visitors for the New Albany Seminary. Allen Wiley, C. W. Ruter, H. S. Talbott, E. R. Ames and I. C. Smith were appointed by the chair on the examining committee to examine candidates for admission into full connection. The following resolutions were offered and on motion adopted:

Inasmuch as this conference considers intemperance a great evil in a social, civil and religious point of view, and, one against which the combined influence of all good men should be expected, therefore,

Resolved, 1st, That we feel deeply convinced of the necessity, importance, and utility of the temperance reformation as carried on by the organization of temperance societies upon the principles of entire abstinence from all intoxicating drinks. ${ }^{4}$

Resolved, 2d, That viewing this organization (which brings to bear against the cause of intemperance the united energies of all the philanthropists, moralists and Christians who will engage therein) as the only safe and speedy remedy for intemperance, and

4 The spresil of intelligence brought about a movement to reform manners. Attention was especially directed to the misuse of spirituous liquors. Total abstinence societies began to be formed about the year 1824 and in five years more than $n$ thomsand had been organized. Zealous preachers of temperance went into every part of the country with the result that many people were enlisted into the movement. In 1830 temperance organizations began to be known as Washington Societies. By 1840 the movement began to work for the prohibition of the sale and mannfacture of spirituons liquors. Bassett. "A Short History of the Inited states." p. 480. 
therefore demand the hearty co-operation of each of the above named classes of society.

Resolved, 3d, That this conference request each preacher to exert his influence in behalf of this good cause by aiding in temperance investigations privately -the organization of societies publicly-soliciting subscriptions for the Indiana Temperance Advocate particularly, as well as other temperance publications in general-that the public may thereby be informed generally on this important subject.

\section{JAMES L. THOMPSON, LEWIS HULBERT.}

The president informed the conference that the next annual session will commence on the $23 \mathrm{~d}$ of October, 1839. Conference adjourned.

Wednesday, eight o'clock a. m. Conference met pursuant to adjournment and was opened according to rule. Journal read and approved. Bishop Soule in the chair. Conference proceeded to business. Conference spent some time in taking the numbers of Sunday Schools, the amount of missionary monies, etc. On motion the vote by which William H. Smith was returned effective was reconsidered, and on motion a supernumerary relation was granted him. A motion was made to change the vote by which I. V. Watson was returned superannuated, which was lost. On motion L. D. Smith was located. These resolutions were offered and adopted:

Resolved, That the thanks of this conference be given to the managers and agents of the Preachers' Aid Society, for the able and satisfactory manner in which they have discharged the trust committed to their care.

Resolved, 2d, That this conference respectfully request the managers of said society to procure an agent, if practicable, for the present year.

Resolved, $3 d$, That the thanks of this conference 
be tendered to the citizens of Rockville for the liberal and hospitabie manner in which they have entertained the members of conference, and the preacher who may be stationed in Rockville make it public.
A. EDDY,
H. S. TALBOTT.

Resolved, That the thanks of this conference be tendered to members of the Presbyterian Church for the use of their house. On motion the following resolutions were adopted:

Resolved, That a committee of three be appointed to draft a memorial to congress, praying the donation of one township of land for the Indiana Asbury University. J. C. Smith, Allen Wiley, and A. Eddy were appointed that committee.

Resolved, That the above committee be requested to draft petitions to be circulated among the preachers for the signatures of the people, praying of Congress such a donation of land. After an appropriate address from the president the appointments of the preachers were read out, and, on motion, conference adjourned to meet at Lawrenceburgh, Dearborn county, Indiana, October 23, 1839.

J. C. SMITH, Secretary.

J. SOULE.

APPOINTMENTS FOR 1838.

Madison District.

Enoch G. Wood, Presiding Elder.

Madison-Edward R. Ames.

Vevay_Sanford S. Williams, William Fraley.

Canaan-Henry S. Dane.

Rising Sun-Fernandes C. Holliday.

Lawrenceburg-Joseph Tarkington.

Wilmington-Charles Bonner, Samuel T. Gillet.

Brookville-James Jones, Lysander Wiley.

Greensburg-Amos Bussey, Melville Wiley. 
Versailles-Lewis Hurlburt.

Vernon-Constant B. Jones.

Scipio-Thomas F. Spillman.

Charlestown District.

Calvin W. Ruter, Presiding Elder.

New Albany-John C. Smith, Silas Rawson.

Corydon-William V. Daniel, John Talbott.

Greenville-Benjamin T. Griflith.

Paoli-Jacob M. Stallard, James Crawford.

Brownstown-Philip May.

Salem-George K. Hester, Jacob Myers.

Lexington-Thomas S. Gunn.

Charlestown-Isaac Owen, Emmons Rutledge.

Jefiersonville-William H. Good.

\section{Indianapolis District.}

Augustus Eddy, Presiding Elder.

Indianapolis-Allen Wiley.

Greenfield-Francis M. Richmond, Jos. S. Barwick.

Shelbyville-James Scott, George Havens.

Rushville-William W. Hibben, James Hill.

Noblesville-Lucian W. Berry, Pleasant E. Royce.

Augusta-Hezekiah Smith.

Franklin-Isaac Crawford, John Edwards.

Columbus-Miltiades Miller, Landy Havens.

Mooresville-John B. Birt, John L. Kelly.

\section{Bloomington District.}

Henry S. Talbott, Presiding Elder.

Bloomington-Charles M. Holliday.

Springville-William Meginnis, Lewis L. Allen.

Bedford-Amasa Johnson.

Greencastle-Ebenezer Patrick.

Greencastle Circuit-Hakaliah Vredenburg, William H. Smith, sup. 
Putnamville-Ezra L. Kemp.

Spencer-Aleander L. Miller.

Brown Mission-Miles Huffaker.

Rockville-Cornelius Swank.

Russelville-William Wilson.

Indiana Asbury University-Cyrus Nutt, John W. Weekley, professors; Samuel C. Cooper, Zachariah Games, agents.

\section{Vincennes District.}

John Miller, Presiding Elder.

Vincennes-Rodman Lewis.

Terre Haute-John Daniel.

Carlisle-Thomas Ray, William F. Wheeler.

Washington-Isaac M'Elroy.

Princeton-William Knowles.

Mt. Vernon-Henry Beharrell, Jacob Miller.

Booneville-Anthony Robinson.

Rome-Jesse C. Harbin.

Evansville-John S. Bayless.

Bloomfield-William J. Borbes.

Terre Haute Circuit-Daniel Demott, Thomas Bartlett.

Crawfordsville District.

T. J. Brown, Presiding Elder.

Crawfordsville-Richard S. Robinson.

Crawfordsville Circuit_Jonas L. Belotte.

Alamo-Daniel H. Dickerson.

Covington-James L. Thompson, Hawley B. Beers.

Newtown-Ancil Beach, George W. Stafford.

Danville-Eli P. Farmer.

Lafayette-John A. Brouse.

Dayton-Elza Van Schoick.

Frankfort-Joseph White. 
Laporte District.

Aaron Wood, Presiding Elder.

Laporte-Richard Hargrave, John B. Jenkins.

South Bend-James S. Harrison.

Niles-William H. Sampson.

Berrien Mission-Joseph Byron.

Kalamazoo-William Todd, Henry Worthington.

Allegan-George Stanley.

St. Joseph-John Ercanbrack, Ebenezer Arnold.

Elkhart-George M. Boyd, Franklin Gage.

LaGrange-Warren Griffith, Erastus Kellogg.

Deep River Mission-Samuel K. Young.

Centerville District.

James Havens, Presiding Elder.

Centerville-J. Kiger, Francis A. Conwell.

Richmond-John W. Sullivan.

Winchester-John H. Hall, Francis H. Carey.

Newcastle-Elijah Whitten.

Munceytown-Greenbery C. Beeks, Eliphelet S. Sheffield.

Marion-John H. Bruce.

Connersville-David Stiver, Seth Smith.

Liberty-Wade Posey-Isaac Kelso.

Pendleton-Daniel K. Stright.

Portland Mission-George W. Bowers.

Logansport District.

George M. Bewick, Presiding Elder.

Logansport-Jacob Colclazier.

Monticello-Enoch Wood.

Independence-William Campbell.

Delphi-Josiah J. Cooper.

Peru-_Jared B. Mershon.

Fort Wayne-James T. Robe.

Warsaw Mission-Thomas P. Owen. 
Rochester Mission-Burroughs Westlake.

William M. Daily transferred to the Missouri conference. Lemuel M. Reeves transferred to the Erie conference.

JOURNAL of the Eighth Session of the Indiana Annual Conference held at Lawrenceburgh, Dearborn County, October 23, 1839.

We chesday morning, nine o'clock. Conference met according to appointment and was opened by Bishop Roberts by reading a portion of the sacred scripture, singing and prayer. The list was called and the following members answered to their names: E. G. Wood, E. R. Ames, S. S. Williams, William Frailey, Henry S. Dane, Joseph Tarkington, Charles Bouner, James Jones, Lewis Hulbert, C. B. Jones, C. W. Ruter, I. C. Smith, William V. Daniel, B. T. Griffith, Philip May, George K. Hester, Thomas S. Gunn, Isaac Owen, William H. Good, Augustus Eddy, Allen Wiley, James Scott, Henry Talbott, C. M. Holliday, Ezra L. Kemp, Miles Huifaker, S. C. Cooper, Zachanah Games, John Miller, John Daniel, Thomas Ray, Isaac McEliroy, Anthony Robbins, Jesse C. Harbin, John S. Bayless, Daniel DeMott, Thomas Bartlett, Thomas I. Brown, R. S. Robinson, Jonas L. Belotte, James L. Thompson, Ancil Beach, E. P. Farmer, John A. Brouse, Joseph White, Aaron Wood, G. M. Boyd, James Havens, John W. Sullivan, Elijah Whitten, G. C. Beeks, David Stiver, Isaac Kelso, G. M. Beswick, Jacob Colclazier, Enoch Wood, James T. Robe, John Kerns, Asa Beck, Robert Burns, James V. Watson, Matthew Simpson.

On motion, conference proceeded to elect a principal and assistant clerk by ballot, and E. R. Ames was elected, and I. C. Smith assistant. On motion, resolved, that we have on session per day and that conference meet at one-half past eight o'clock a. m. and adjourn at one-half past twelve p. m. 
Conference proceeded to elect three stewards, and on counting the ballots, S. C. Cooper, James Scott and A. Wiley were elected. Two communications from the book agents from New York were read and referred to the said book committee which were elected by the conference, viz: John Brouse, William H. Gooble, and John Daniel. The agents at New York requested that conference appoint a committee to obtain a correct list of the postofifices in the circuits and stations and forward the names to the agents, and H. S. Talbott, Aaron Wood, and R. S. Robinson were appointed that committee. On motion the by-laws of the former session were read and adopted for the government of this session.

On motion, resolved, that we will observe Friday the twenty-fifth instant, as a day of religious devotion in reference to the Centenary of Methodism. ${ }^{1}$ On motion, resolved, that a committee of five be appointed to make arrangements for the celebration, and Allen Wiley, C. W. Ruter, A. Eddy, E. R. Ames and E. G. Wood were appointed said committee.

On motion, resolved, that during the examination of character the conference sit with closed doors; none but members and probationers are allowed to be present. Conference took up the second question on the minutes, viz.: Who remain on trial? And the charac-

$1 \mathrm{On}$ that day Dr. Simpson, the young president of Asbury Iniversity, male his first anpenrence in the Indiana Couference. "His personal appearance was a perpetual disappointment. He was too youthful to meet expectation, being less than thirty years old, and his dress was of jeans, neat and well-fitting; but not what most expected of so distinguished a man. His praise as a preacher was in all the land. and every one desired to hear him. This opportunity eame in his sermon on the itinerary of Methodism. It was a very powerful one and dealt largely with the then much discussed question of the millemium. Such was the force and eloquence of the young man, that many were overcome with emotion and he was "at once roted the prince of pulpit orators." Autohiography of Joseph Tarkington, pp. 17-20. 
ters of Melville Wiley, Seth Smith, John Schatt, John A. Kelly, Hezikiah Smith, L. W. Berry and Cyrus Nutt were severally examined and passed and continued on trial. Lewis L. Allen was discontinued. The characters of Henry Beharrell, William F. Wheeler, George W. Stafford, William Wilson, William H. Sampson, Francis A. Conwell, John H. Hull, Lysander Wiley, James Hill, George Havens, Elisha Vanschoick, and William Campbell were severally examined, passed and continued. J. J. Cooper was discontinued. J. B. Jenkins was continued on trial. Conference adjourned.

Thursday morning one-half past eight o'clock. Conference met pursuant to adjournment and was opened according to rule. Journal was read and approved. Conference proceeded to business, Bishop Roberts in the chair. The conference stewards spent some time in attending to their business. Conference resolved to draw on the book concern for $\$ 500$, and on the charter fund for $\$ 86$.

On motion, resolved, that a financial committee of five be appointed to lay before this conference a plan for the purpose of producing a uniformity in the fiscal transactions of the church in this conference. And A. Eddy, C. W. Ruter, S. C. Cooper, A. Wood and I. C. Smith were appointed that committee.

The committee of arrangements for the centenary celebration reported as follows: That a prayer meeting be held in the Methodist church at sunrising and conducted by Rev. James Havens. That a sermon be delivered at ten o'clock at the same place, by Rev. M. Simpson. That there be a centenary meeting at three o'clock at the conference for the purpose of receiving centenary offerings. And that the missionary society hold its anniversary meeting at candle lighting at the Methodist church. The above report was accepted.

Conference resumed the second question on the minutes, viz. : Who remain on trial? and the characters of 
Daniel K. Stright, Ebenezer Arnold, Landy Havens, Joseph Byron, Samuel K. Young, Daniel Worthington, Franklin Gage and James Crawford were severally examined, approved, passed and continued on trial. E. S. Sheffield and George Stanley were discontinued.

Conference then took up the consideration of the third question on the minutes, viz.: Who are admitted into full connection? When the brethren who had been previously examined by the committee, appointed for that purpose, were called forward by the Bishop and questioned by him as the discipline directs: the characters of S. T. Gillett, Isaac Crawford, Thomas F. Spillman, I. B. Burt, John Edwards, Miltiades Miller, William M. Guines, Jacob Myers, William H. Forbes, Francis H. Casey, Emmons Rutledge, John Kiger, George W. Bowers, Alexander L. Miller, Amos Bussey, Silas Rawson, William Knowles, John W. Weekly, Wade Posey, Hawley B. Beers were severally examined and passed and elected to Deacons Orders, except Isaac Crawiord, Thomas F. Spillman and Amos Bussey who had been pieviously ordained to that office. Thomas F. Spillman was elected to Elders' Orders. Daniel H. Dickinson was discontinued at his own request. P. E. Royce was discontinued and also Thomas P. Owen in consequence of ill health. Conference adjourned.

Saturday, one-half past eight o'clock. Conference met pursuant to adjournment and was opened according to rule. Journal read and approved. Conference proceeded to business, Bishop Morris in the chair.

Conference took up the fifth question on the minutes, viz.: Who are elected to Elders' Orders? The characters of Isaac McElroy, Jacob M. Slallard, B. F. Griffith, John S. Bayless, G. C. Beeks, Thomas L. Gunn, Isaac Owen, James $V$. Watson were severally examined and elected to said orders. Conference then took up the consideration of the local preachers recommended for Deacons Orders. Elijah Barwick, William J. 
Flemming, John Fish, George C. Shively, Jr., Silas Igan and William A. Aldred were elected to Deacons Orders. Peter Weaver was not elected. Jacob Bruner, Thomas B. Springer, John L. Pinkston, Samuel Smith, Adison Lane, James Latta, William Morely, Elhannon Sweet, D. K. Straight, Stephen Norman, Albert G. Perkins and B. H. Bradbury were elected to Deacons Orders. Conference then took up the consideration of local deacons recommended for Elders Orders, and Jacob Johnson was elected. Thomas Manwarning was not elected, Orthniel Talbott was not elected. The parchments of Elijah Burns were handed over to the conference. Robert Parrot was elected. Conference then took up the case of Jacob Miller whose character was examined, admitted into full connection and elected to Deacons Orders. Isaac Merrill was elected to Elders Orders. A communication, signed by the president of the board of trustees of Indiana Asbury University, was read, which, on motion, was laid on the table. On motion, resolved, that a committee of three be appointed, to whom the preachers shall report the names and amounts of all who have contributed to the centenary fund, and register the same into a book prepared for that purpose; and make a full report to the conference of all money and papers relating to the centenary operations. C. W. Ruter, Allen Wiley and Richard Hargrave were appointed that committee.

Conference took up the consideration of the fourth question on the minutes, viz.: Who are the deacons? And the characters of William H. Good, Ezra L. Kemp, John A. Bruce, William Fraley, Anthony Robinson, Isaac Kelso, George M. Boyd and Jacob Colclazier were severally examined and passed. On motion the vote by which Josiah J. Cooper was discontinued was reconsidered and he was continued on trial. Cn motion, the vote by which Lewis L. Allen was discontinued be reconsidered, and he was continued on trial. Confer- 
ence took into consideration the first question on the minutes, viz.: Who are admitted on trial? Peter $\mathbf{R}$. Guthrie, Daaper Chipman, John F. Truslow, having been properly recommended, were admitted on trial. When, on motion, conference adjourned.

Saturday, two o'clock p. m. Conference met pursuant to adjournment and was opened according to rule. Journal read and approved. Conference proceeded to business. Bishop Roberts in the chair. Conference resumed the first question on the minutes. Lealdes Forbes, Stephen Ravenscroft, Walter L. Huffman, Elijah P. Bracher, B. H. Bradbrugh, Joseph Ocherman, G. W. Adams, Hayden Hayes, Thomas H. Rucher, John Cowgill, William Bratton, Wesley Dorsey, Oliver S. Wells, John S. Donaldson, Samuel H. Rogers, John V. R. Miller, R. C. Rowley, John H. Worthing, Enoch Halstock, George W. Baker, Robert Curran, E. F. Remington, George W. Walker, Edward Oldham, James R. Williams, Washington Malick, Landy Roberts, and J. F. Truslow, having been properly recommended, were admitted on trial. Conference adjourned to meet on Monday at half-past eight o'clock a. $m$.

Monday, one half past eight o'clock a. m., conference met pursuant to adjournment and was opened according to rule. Journal read and approved, Bishop Morris in the chair. Conference proceeded to business. L. Swormsteat read before conference an exhibit of the Western Book Concern, which was ordered to be filed with the conference papers. A communication was received from the secretary of the Indianapolis Bible Society, which being read, was, on motion, laid on the table. A communication from the New York conference respecting certain temperance resolutions, was read before conference, and on motion, Resolved that our conference concur with the resolutions of the New York conference on that subject, which carried by 
a vote of seventy-nine to aught. A communication from the New England conference, on the subject of Slavery was laid before the conference by the president, which, on motion, was acted upon without debate. ${ }^{2}$

On motion, Resolved that conference do not concur in said resolutions, which carried by a vote of eightyone to 0 , and on motion, resolved, that the balance of the resolutions from said conference be indefinitely postponed. Bishop then asked who are readmitted? William B. Kops, Allen D. Beasley, Henry Vanorder were readmitted. The stewards then spent some time in attending to their business. When conference proceeded to the examination of the characters of the elders. And, on motion, Resolved that the Presiding Elders only be requested to withdraw from the room during the examination of characters, and E. G. Wood, E. R. Ames, S. S. Williams, H. S. Dane, F. C. Holliday, Joseph Tarkington, Charles Bonner, James Jones, Lewis Hulbert, C. B. Jones, C. W. Ruter, I. C. Smith, William V. Daniel, Philip May, Isaac Owen, Augustus Eddy, Allen Wiley, Frances M. Richmond, James Scott, W. W. Hibben, H. S. Talbott, C. M. Holliday, Amasa Johnson, E. Patrick, H. Vredenburgh, were examined and passed. The characters of William $\mathrm{H}$. Smith was examined and passed and his relation changed from supernumary to effective. The characters of Miles Huffaker, Samuel C. Cooper, Zachariah Games, were examined and passed. The character of John Kerns was examined and passed and his supernunary relation changed to effective. Asa Beck's character passed and his relation continued superanuated. Robert Burns character passed and his relation

2 It is a significant fact that the commumieation on slavery came from the New England states, as there was situited the heart of the anti-slavery morement. The first Methodist antislavery societies were formed in New Englanu. (Nweet Methodist Episcolal Church ind the Civil Wir, 19-20.) 
changed from superannuated to effective. William Shanks character passed and his superannuated relation continued. John Richie's character passed, and a motion was made to locate him, which, after some debate, was withdrawn. A motion was then made to render him effective, which was lost. It was decided that his superannuated relation be continued, which was carried. James V. Watson's character was examined and passed, and his relation was changed from superannuated to effective. The character of John Miller was passed. Rodman Lewis's name was called, and after some debate, his case was, on motion, referred to a committee of three, viz., A. Wiley, I. L. Thompson and Joseph Tarkington. The characters of John Daniel, 'ihomas Ray, J. C. Harbin, Daniel DeMott, Thomas Bartlett, Thomas J. Brown, R. S. Robinson, James L. Thompson, Jonas L. Belotte, A. Beach, E. P. Palmer, were severally examined and passed, and Brother Farmer asked and received a local relation. John A. Brouse and Joseph White were examined and passed. On motion, Brothers Eddy, Ruter and Cooper were excused from acting on the financial committee, and, on motion, William C. Good, John S. Bayless and John Daniel were nominated and elected to fill those vacancies. Conference adjourned.

Tuesday, October 29th, one half past eight o'clock a. m., conference met pursuant to adjournment and was opened according to rule. On motion, the calling of the list was dispensed with the balance of the session. The Journal was read, amended and approved. Conference proceeded to business, Bishop Morris in the chair. Brother Swormstedt spent some time in attending to business of the Western Book Agency. The committee appointed in the case of Rodman Lewis reported as follows: The committee beg leave to report that from all the information they can get on the subject, there has been such a total disregard of pre- 
ordination vows and such duplicity on the part of the said Lewis, that your committee deem him unworthy of an accredited standing as a christian minister in the Methodist Episcopal Church, or other respectable denomination, in view, however, of the facts, that he had connected himself with another denomination, and declared himself withdrawn from ours before any action was had in his case, we would recommend that it be stated upon the Journal of the conference, that said Lewis has withdrawn from our connection, and that it be so stated on the minutes of conference, of which is respectfully submitted.

A. WILEY, Chairman.

Said report was read, amended, and adopted, and, on motion, the secretary was requested to furnish said Lewis with a copy of said report. On motion, Aaron Wood was appointed to fill the vacancy in the Missionary Committee, occasioned by the absence of William Shanks.

Conference resumed the examination of the characters of elders, the characters of Aaron Wood, William Todd, John Eecanbrack, Erastus Kellog, Richard Hargrave, B. Weslake, Warren Griffith, James Havens, I. W. Sullivan, Elijah Whitten, David Stiver, were severally examined and passed. Conference resolved, that Brother Stiver is justifiable in claiming quarterly for his wife. The characters of George W. Beswick, Enoch Wood, James T. Robe were severally examined and passed. Brother Robe asked and obtained a location.

The case of Joseph Barwick was considered and he continued on trial. On motion, the vote by which Joseph E. Beecher was admitted on trial was reconsidered and his Presiding Elder asked and obtained leave to withdraw his recommendation. On motion, Resolved, that Brother Eddy be appointed to receive and pay over all centenary monies appropriated to any 
specific purposes, and that all other monies not thus appropriated by donors, shall be given to the Indiana Asbury University. A communication from the Board of Managers of the Preachers' Aid Society requesting the appointment of the Rev. James S. Harrison, as an agent for the society, during the present year, and, on motion, their request was granted. The committee to whom was referred the request of the agents of New York on the subject of postoffices, reported it impracticable to comply with their request, and asked leave to be discharged from further considerations of the subject, which was granted. Conference proceeded to fix the place of its next annual meeting, and on counting the votes, Indianapolis received the majority of votes. A motion was made to go into the election of delegates to General Conference, which was lost. Resolved, that the Bishop be requested to assign to the different members of the examining committee the respective branches of study on which each shall examine. Resolved, that conference take up, examine, amend, and adopt the course of study prepared by Bishop Soule, or some other furnished by the Bishop now present. Signed by A. Wiley and A. Eddy.

On motion, Resolved, that the Bishop be requested to prepare a course of study for the preachers on trial for the first year, and appoint a committee to examine them. A motion was made to extend the course of study to the third and fourth year, which was lost. Conference adjourned.

Wednesday, one half past eight o'clock a. m., conference met pursuant to adjournment, and was opened according to rule. The Journal was read, amended and approved. Conference proceeded to business, Bishop Morris in the chair. On motion, Resolved, that the Bishop be requested to transfer Joseph Marsee to this conference. 
Bishop Morris reported the following course of study for the first year, also the committee:

First year-The Bible, as to doctrine, with the aid of Wesley's Notes, and Watson's Dictionary, C. W. Ruter.

Wesley's Sermons-Aaron Wood.

Fletcher's Appeal-James Havens.

English Grammar and Composition-Ebenezer Patrick.

Second Year-The Bible generally, with the aid of Benson's or Clark's Commentary-A. Wiley.

The Discipline of the Methodist Episcopal Church -A. Eddy.

Watson's Life of Wesley-Samuel C. Cooper.

The Doctrinal part of Watson institutes-E. $\mathbf{R}$. Ames.

Ruter's Church History-M. Simpson.

English Grammar and Composition-J. C. Smith.

N. B.-The person first named for each year is chairman of the committee, and in case any member of his committee be absent, he shall conduct the examination on the branch assigned such absent member or appoint some one to do it for him. On motion, Resolved, that two hundred copies of study be printed for the use of conference, of the work can be done before conference adjourns. On motion, F. C. Holliday and John S. Bayless were appointed a committee to attend to that business.

The stewards then presented their report which was read, amended and approved. The stewards reported the appropriation which they have made of funds arising from the Preachers' Aid Society, which on motion, was laid on the table.

On motion, O. S. Powell, boatman chaplain, at Cincinnati, was permitted to address the conference on the subject of his agency. Whereupon the following resolutions unanimously passed, viz., Resolved, that 
we cordially approve the object of the Boatmen Bethel Society on our navigible waters. A. Eddy, A. Wiley.

Second, Resolved, that we recommend to our members and ministers to aid in promoting religion among the boatmen within our bounds. A. Eddy, A. Wiley.

The number of members was then called for, after which the missionary committee made their report, which was adopted. When, on motion, the conference went into the election of delegates to the next General Conference and on counting the votes, A. Wiley, E. R. Ames, C. W. Ruter and A. Eddy were declared duly elected on the first ballot. On the second balloting, there was no choice. On motion, Resolved, that conference continue its present session half an hour. After three ballotings, Aaron Wood was declared duly elected. A committee of three were appointed to estimate the table expenses of Bishop Roberts. Brothers Ruter, Wiley and Thompson were elected that committee.

A preamble and resolutions were offered by $\mathrm{C}$. W. Ruter and A. Wiley by which Bishop R. R. Roberts, in consequence of his increasing infirmities, be requested to remove to some prominent point in this state which may best suit his feelings, where his brethren and friends may have more ready access to him, that they may render him such attention as the church feels anxious he should receive. By a rising vote, conference unanimously resolved to make the request. On motion, resolved, that this conference will cordially receive Brother Edward Smith of the Pittsburgh conference, if the Bishop will transfer him.

On motion, resolved that conference adjourn to meet at half past two o'clock p. m., conference adjourned.

3 Bishop Roberts, however, in spite of the urgent request of the Indiana Conference and of those of severil personal friends in that Conference, declined to move. At his advanced age he did not think it wise to change his residence and form "new neighborhood alliances." (Elliott. Life of Roberts, 336.) 
Wednesday, one half past two o'clock p. m., conference met pursuant to adjournment and was opened according to rule. The Journal read and approved, and, on motion, conference proceeded to business, Bishop Morris in the chair. Conference proceeded to elect two reserved delegates and on counting the votes, John C. Smith was elected on the first ballot, and John Miller on the second ballot. On motion, conference proceeded to elect nine visitors to the Indiana Asbury University. On counting the votes, A. Wiley, S. C. Cooper, James L. Thompson, Edward R. Ames, C. W. Ruter, J. C. Smith, James Havens, A. Eddy and H. S. Talbott were declared duly elected. The following resolutions were then offered and passed:

Resolved, that our delegates to the next General Conference be, and are hereby instructed, to use their influence to make the line dividing the state of Indiana and Michigan the northern boundary of this conference. S. C. Cooper, James Havens.

Resolved, that our delemates to the next General Conference be, and they are hereby instructed, to use thir influence to make the line dividing the state of Indiana and Illinois the western boundary of the Indiana conference. S. C. Cooper, A. Wiley.

Resolved, that the preachers of this body be requested to return to the original plainness of Methodism i. e., that they all be requested to wear either the round breasted or plain frock coat. Thomas I. Brown, I. White.

Resolved, that a committee of three be appointed to employ a person suitable to record the names of donors of centenary offerings, and that said committee report to the next annual conference.

Resolved that said committee are hereby instructed to have said names recorded with india ink in a suitable book, procured by them prepared for that purpose. A. Wiley, J. T. Robe. 
On motion, the committee formally appointed to attend to this business was released, and, on motion, Brothers A. W. Morris and A. Harrison and the preacher in charge of Indianapolis station were appointed that committee.

Joseph Carter was recommended from the Madison district and received on trial.

The report of the Board of Visitors of the Indiana Asbury University was read, and on motion, James Fisk and Daniel Harrell were elected to fill two vacancies in the Board of Trustees of said university in the places of Samuel Taylor and Calvin Fletcher, whose seats were vacated in consequence of their absence.

On motion, the report of the stewards in reference to the income from the Preachers' Aid Society was adopted. On motion, conference adjourned.

Tuesday, one half past eight o'clock a. m., conference met pursuant to adjournment and was opened according to rule, and Journal read.

On motion, the vote by which George M. Beswick was superannuated, was reconsidered and he received an effective relation. On motion, the vote by which Daniel Harrell was elected a trustee of the Indiana Asbury University was reconsidered, and, on motion, A. W. Morris was elected to that office. On motion, the vote by which Lewis Roberts was received on trial, was reconsidered and, on motion, his Presiding Elder obtained leave to withdraw his recommendation. The stewards made their report of the disposition which they had made of the funds which they obtained of the Preachers' Aid Society, as follows:

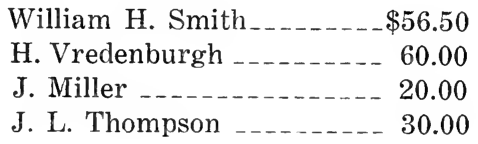


J. Kerns

M. Huffaker 30.00

All of which is respectfully submitted.

The committee appointed to estimate the expenses of Bishop Robert's family, reported an allowance of $\$ 300$, which was adopted. The financial committee presented their report, which was read, and on motion, was adopted and ordered to be published in the Christian Advocate. The book committee presented their report, which was read, and on motion, adopted. Resolved, that the American Colonization Society ${ }^{4}$ are entitled to the confidence and support of our ministers and members, and is therefore recommended to their charities and general co-operation. A. Eddy, E. R. Ames.

On motion, resolved that the Bishops be, and they are, hereby requested to appoint the next and following session some time during the month of September.

Resolved, that each preacher in charge be directed so soon as may be to make collections to defray the expenses of delegates to the next General Conference, and that they place the same in the hands of the delegates before they start to conference.

On motion, the stewards are directed to pay over the surplus to Thomas Owen. On motion, resolved that a vote of thanks be tendered to the citizens of this town for the hospitality shown to the preachers during the

4 This society was formed in the year 1s16, in the eity of Washington and rery som there were auxiliary branches formed in most of the states. "In its original formation and subsequent progress, in its arowals, arguments and acts, it was always singularly inconsistent and illogical. It manifestly yielded and pandered to the wicked prejudice against race and color, and yet it called upon churches and Cluristians to assist in sustaining it as an essential part of the missionary enterprise." In reality its purpose was supposed to be that of taking the free negroes to Africa and there giving them is chance to govern themselves. (Wilson. "Iise and Fall of the slave lower in America," 208.) 
session of conference, and also to the pastors and members of the Presbyterian and Baptist Churches for the use of their houses of worship during the session of this conference. On motion, Resolved, that the editor of the Beacon be requested to publish the foregoing resolutions.

The appointments having been read by Bishop Morris, conference adjourned.

THOMAS A. MORRIS.

E. R. AMES, Secretary.

Lawrenceburg, October 31, 1839.

APPOINTMENTS FOR 1839.

Madison District.

C. W. Ruter, Presiding Elder.

Madison-F. C. Holliday, Wm. M. Fraley.

Canaan-H. S. Dane.

Vevay-C. B. Jones, George W. Ames.

Rising Sun-S. T. Gillett, P. R. Guthrie.

Lawrenceburg-Wm. W. Hibben.

Wilmington-Charles Bonner, Hayden Hays.

Versailles-L. Hurlburt.

Paris-Amos Bussey, J. C. Harbin.

Indiana German Mission-To be supplied.

Charlestown District.

E. G. Wood, Presiding Elder.

New Albany-J. C. Smith, Wm. Knowls.

Corydon-J. A. Brouse, W. Malick.

Greenville-Thomas S. Gunn.

Rome-B. T. Griffith.

Salem-W. V. Daniel, James Crawford.

Charlestown-Isaac Owen, T. J. Doyle.

Lexington-E. Rutledge, E. Oldham.

Jeffersonville-William $\mathrm{H}$. Goode. 
Indianapolis District.

A. Eddy, Presiding Elder.

Indianapolis-A. Wiley.

Noblesville-L. W. Berry, J. V. R. Miller.

Mooresville-Isaac Crawford, Thomas H. Rucker.

Franklin-Miles Huffaker, Isaac Kelso.

Shelbyville-R. Hargrave, Joseph Barwick.

Rushville-James Hill, E. F. Remington.

Knightstown-J. B. Birt, J. L. Kelley.

Greenfield-F. M. Richmond, George Havens.

Pipe Creek Mission-S. S. Williams.

Agent for Preachers' Aid Society-J. S. Harrison.

\section{Vincennes District.}

John Miller, Presiding Elder.

Evansville-John Daniel.

Mount Vernon-Henry Beharrel, Samuel H.

Rogers.

Princeton-Anthony Robinson.

Boonville-Stephen Ravenscroft, W. F. Wheeler.

Vincennes-John Kearns.

Washington-Silas Rawson.

Bloomfield-Isaac McElroy.

Carlisle-Thomas Ray, Jacob Miller.

Knox Mission-William Bratton.

Crawforlsille District.

T. J. Brown, Presiding Elder.

Lafayette-H. B. Beers.

Dayton-William Wilson.

Frankfort-Joseph White, George W. Stafford.

Covington-James L. Thompson, Walter L. Huffman.

Newtown-Allen D. Beasley, one to be supplied.

Crawfordsville-Richard S. Robinson. 
Crawfordsville Circuit-Daniel Demott.

Danville-Enoch Wood, Wesley Dorsey.

Greencastle District.

E. R. Ames, Presiding Elder.

Greencastle-John S. Bayless.

Greencastle Circuit-H. Vredenburg, R. C. Rawly.

Putnamville-W. H. Smith.

Russellville-Ezra L. Kemp.

Rockville-Amasa Johnson.

Terre Haute-Ebenezer Patrick.

Terre Haute Circuit-C. Swank, Thomas Bartlett. Alamo-John Edwards.

Indiana Asbury University-M. Simpson, C. Nutt. J. W. Weakly; Samuel C. Cooper, agent.

Bloomington District.

H. S. Talbott, Presiding Elder.

Bloomington-Robert Curren.

Springville-Alexander L. Miller.

Bedford-C. M. Holliday.

Brownstown-P. May, James R. Williams.

Columbus-G. K. Hester, D. Chipman.

Spencer-J. M. Stallard, L. Forbes.

Paoli-William McGinnis, John Talbott.

Brown Mission-Thomas F. Spillman.

Richland Mission-George W. Walker.

\section{Connersville District.}

James Havens, Presiding Elder.

Connersville-Miltiades Miller, G. W. Bowers.

Centerville-J. W. Sullivan, Joseph Carter.

Newcastle-James Scott.

Liberty-John Kizer, Landy Havens.

Brookville-James Jones, F. A. Conwell.

Greensburg-William B. Ross. 
Milroy-E. Whitten, F. H. Cary.

Scipio-Jacob Myers.

Richmond District.

Robert Burns, Presiding Elder. Richmond-Joseph Tarkington. Winchester-J. H. Bruce, Joseph Ockerman.

Portland-Barden H. Bradbury. Munceytown-John H. Hull. Marion-Daniel K. Stright. Andersontown-Hezekiah Smith. Pendleton-John S. Donaldson. Bluffton Mission-Seth Smith.

\section{Logansport District.}

George M. Beswick, Presiding Elder.

Logansport-John F. 'Truslow.

Peru-Burroughs Westlake.

Little St. Joseph's Mission-Samuel Reed.

Fort Wayne-Jacob Colclazer.

Delphi-Ancil Beach.

Independence-William Campbell, John Sougill.

Monticello-Joseph J. Cooper.

Rochester Mission-J. B. Mershon.

Miami Indian Mission-J. L. Belotte.

South Bend District.

Aaron Wood, Presiding Elder.

South Bend Station-David Stiver.

Mishawaka-Warren Griffith.

Goshen-George M. Boyd.

LaGrange-Wade Posey, Lewis L. Allen.

Steuben-S. K. Young, E. Holdstock.

Laporte-Z. Games, George W. Baker.

Kankakee Mission-William J. Forbes.

Warsaw-Elza Van Schoick. 


\section{Michigan District.}

John Ercambrack, Presiding Elder.

Niles-William H. Sampson.

Edwardsburg-Joseph Byron.

White Pigeon-James V. Watson.

Centerville-Erastus Kellogg.

Kalamazoo-Harvey Van Order, O. S. Wells.

Berrien Mission-Franklin Gage.

Pawpaw Mission-Henry Worthington.

Allegon-William Todd.

Melville Wiley and Lysander Wiley transferred to the Missouri conference.

Ebenezer Arnold, transferred to Black River conference.

John B. Jenkins, transferred to Genesee conference.

JOUPNAL of the Ninth Annual Session of the Indiana Conference of the Methodist Episcopal Church at Indianapolis, Indiana, October 21st, 1840.

Wednesday morning at 9 o'clock a. m. conference met pursuant to adjournment, and no superintendent being present, on motion of E. R. Ames, Brother Eddy was requested to take the chair, and organize the conference. The conference was opened by Brother James Jones by reading a portion of Scripture, singing and prayer. The secretary of the former conference, having called the list, the following members answered to their names: Calvin W. Ruter, E. G. Wood, Thomas J. Brown, E. R. Ames, Augustus Eddy, John Miller, Henry S. Talbott, James Havens, Robert Burns, Geo. M. Beswick, Aaron Wood, Henry S. Dane, C. B. Jones, William W. Hibben, Lewis Hulbert, J. C. Harbin, John A. Brouse, William V. Daniels, Allen Wiley, R. Hargrave, John Daniel, John Kerns, Thomas Ray, Allen D. Beasly, Daniel Demott, Enoch Wood, John S. Bayless, H. Vredenburgh, Amasa Johnson, E. Patrick, 
Cornelius Swank, Thomas Bartlett, Samuel C. Cooper, Charles M. Holliday, Philip May, J. W. Sullivan, James Jones, J. Tarkington, Ancil Beach, Jonas L. Belotte, Isaac Crawford, William McGinnis, Amos Bussy, E. L. Kemp, J. H. Bruce, J. B. Neishon, A. Robinson, Isaac Kelso, George M. Boyd, Jacob Colclazin, Samuel S. Gillet, John B. Burt, John Edwards, Jacob Myers, Francis Carey, Emmons Rutledge, John Kizer, George W. Bowers, Wade Posey, William Shanks, Greenbury C. Beeks, Charles Bonner.

On motion, Resolved, that conference proceed to elect a secretary by ballot, and on counting the votes, Edward R. Ames having received a majority of all the votes given, was declared duly elected. On motion, Resolved, that conference proceed to elect an assistant secretary, and on the second ballot, Ebenezer Patrick, having received a majority of the votes given, was declared duly elected. On motion, conference proceeded to elect a president pro tem. and on the third ballot, Calvin W. Ruter, having received a majority of all the votes given, was declared duly elected, and after having made a few appropriate remarks, took the chair, and conference proceeded to business.

On motion, it was resolved that conference will meet at half past eight in the morning, and adjourn at twelve o'clock noon. Conference then proceeded to elect three stewards by ballot, and Samuel C. Cooper, William Shanks and John Daniels having received a plurality of votes, were declared duly elected. On motion, it was resolved that a committee of three be appointed to appoint the preachers to officiate in the different churches during the session of the conference, and also to superintend the congregations, and Augustus Eddy, Allen Wiley and John A. Brouse were appointed that committee. On motion, it was resolved that a book committee of three be appointed and William V. Daniels, Charles M. Holliday and Samuel T. 
Gillet were appointed that committee. On motion, it was resolved that the by-laws of the former session be aciopted for the government of the conference, during its present session, and having been read, they were adopted without amendment. On motion, a committee of three to be denominated the committee on finance, was appointed, whose duty it shall be to take into consideration the best method of raising funds on the circuits and in the stations, for the support of the preachers, and James Jones, Lewis Hurlbott and Zachariah Games were appointed that committee. On motion, conference adjourned.

Thursday, at half past eight o'clock a. m., conference met pursuant to adjournment. Bishop Soule, having arrived, took the chair and opened the conference by reading a portion of the sacred Scripture, singing and prayer; the list was called, the journals read and approved, and conference proceeded to business, Bishop Soule in the chair. On motion, it was resolved that the secretary be authorized to purchase a suitable book in which to transcribe all the proceedings of the Indiana annual conference, from its commencement, and to be used by the conference in the future. Bishop Soule presented a letter from the book agents, G. Mason and G. Lane, giving an exhibit of the Methodist Book Concern, January 1, 1840, which was read and filed among the papers of the conference, also an account against the preachers of the conference which was referred to the appropriate committee. A communication from Bishop B. Waugh was read transferring William M. Daily from the Missouri to the Indiana conference; also a communication from Brother Daily, which was also read and filed. The stewards called upon the members of the conference for an exhibit of their claims and receipts, and the amounts of the conference collections. The conference voted to draw on the book concern for six hundred dollars and 
also to draw on the chartered fund for seventy-five dollars. A communication from J. Bockman, chairman of the board of stewards of the Michigan conference, stating that their claim on the funds of this conference for the benefit of those preachers who were struck off together with the Michigan district to that conference, by the action of the late General Conference, amounts to $\$ 41.80$, and on motion, the stewards were authorized to pay over the amount. On motion, it was resolved that in compliance with the recommendation of the late General Conference, we will sit with closed doors during the examination of character. Conference took up the consideration of the second question on the minutes, viz: Who remain on trial? And the characters of Peter R. Guthrie, Thomas J. Boyle, George W. Walker, George W. Ames, Edward Oldham, Washington Malick, Joseph Carter, Draper Chipman, Hayden Hays, Samuel H. Rodgers, James R. Williams, John V. R. Miller, John F. Truslow, Sealdes Forbes, Rosetter C. Rowley, were severally examined, passed, and they continued on trial. Robert Currain was discontinued at his request. Elkanah F. Remington was discontinued. On motion, it was resolved that when conference adjourns, it adjourn to meet at two o'clock p. m., and that the afternoon session be exclusively devoted to examination of character. On motion, John Cowgill was discontinued. The character of George W. Baker, Stephen Ravinscroft, William Bratton, Walter L. Huffman, Wesley Dorsey, John S. Donaldson, Barden H. Bradbury, Joseph Okerman, Samuel Reed, Enoch Holstock, were severally examined, passed and they continued on trial. When conference adjourned.

At two o'clock p. m., conference met pursuant to adjournment and was opened by C. W. Ruter, by reading a portion of Scripture, singing and prayer: the list being called, the journals read, and approved, conference proceeded to business, Bishop Soule in the chair. 
Conference took up the consideration of the fourth question on the minutes, viz: Who are the deacons? And the character of Samuel T. Gillet, John B. Burt, John Edwards, Jacob Myers, Jacob Miller, Wm. J. Forbes, Francis H. Carey, Emmons Rutledge, John Keiger, George W. Bowers, Alexander L. Miller, Silas Rawson, William Knowles, John W. Weekly, Hauley B. Beers, Wade Posey, were severally examined, and passed. Conference took up the consideration of the fifth question on the minutes, viz: Who are eligible to elder's orders? And the characters of Isaac Crawford, Miltiodes Miller, William McGinnis, Amos Busscy, William H. Goode, Ezra L. Kemp, John H. Bruce, William M. Fraley, Jared B. Mershow, Anthony Robinson, George M. Boyd, Jacob Colclazer and William B. Rop, were severally examined, approved and passed, and elected to elder's orders, and William B. Rop, through his presiding elder, asked and obtained a location. Isaac Kelso was not elected to elder's orders, but his character passed.

The conference then took up the examination of the character of elders, whereupon, the character of Calvin W. Ruter, Enoch Wood, Augustus Eddy, John iviller, Thomas J. Brown, Edward R. Ames, Henry S. Talbott, James Havens, Robert Burns, George M. Beswick and Aaron Woode were severally examined and passed. On motion, conference adjourned.

Friday, at half past eight o'clock a. m., conference met pursuant to adjournment, and was opened by Rev: James Jones, by reading a portion of the Scripture, singing and prayer, the list being called, the journals read and approved, conference proceeded to business, Bishop Soule in the chair. The stewards spent some time in attending to their business. The conference instructed the stewards to meet the claim of John $\mathrm{H}$. Worthing, who was received on trial in this conference at its last session, but who in consequence of an omis- 
sion on the part of the superintendent was not appointed to any work, and who died about the middle of the conference year. Conference proceeded in the examination of the characters of elders. And the characters of F. C. Holliday, H. S. Dane, C. B. Jones, W. W. Hibben, L. Hurlbutt, C. Bonner, J. C. Smith, J. C. Harbin, J. A. Brouse, T. S. Gunn, B. T. Griffith, W. V. Daniel, Isaac Owen, A. Wiley, M. Huffacer, R. Hargrave, F. H. Richmond, S. S. Williams, J. S. Harrison, J. Daniel, J. Kearns, J. McElroy, Thomas Ray, Joseph White, J. I. Thompson, A. D. Beasley, R. S. Robinson, D. Demott, Enoch Wood, J. S. Bayless, H. Vredenburgh, William H. Smith, Amasa Johnson, E. Patrick, C. Swank, T. Bartlett, S. C. Cooper, C. M. Holliday, P. May, G. H. Hester, T. F. Spilman, J. Tarkington, B. Westlake, A. Beach, J. S. Ballote, D. Stiver, L. Games, W. Griffith, J. W. Sullivan, J. Scott, J. Jones, E. Whitton, J. Richie, W. Shanks, Asa Beck, G. C. Beeks, W. M. Daily, M. Simpson, J. M. Stallard, were severally examined and passed. Sanford S. Williams, James L. Thompson, Hezikiah Vredenburgh, Burrows Westlake, Daniel Stiver and William M. Daily, through their representatives asked and received superannuated relations. J. Richie, William Shanks, A. Beck, were continued in their superannuated relation to this conference. G. C. Beeks asked to have his relation changed from superannuated to effective, which was granted. Bishop Soule informed the conference that he received official information from Bishop Morris that he had transferred Joseph Marsu, an elder from the Kentucky annual conference, to this conference, and directed his name to be entered upon the list. The following preamble and resolution were offered: Whereas, the marriage and separation of Brother Daniel Stiver and his wife has been very unfortunate, and, whereas she has persisted for years in her refusal to live with him, the church is unwilling to recognize her as a claimant for 
support as his wife. Therefore, Resolved, by the Indiana annual conference of the Methodist Episcopal Church, that we advise Brother Stiver to proceed immediately to take such steps as will effect a dissolution of his obligations to her. ${ }^{1}$ (Signed) Aaron Woode, G. M. Beswick. On motion, this subject was referred to a select committee of three and Matthew Simpson, William M. Goode and Charles Bonner were appointed that committee. Resolved, that when conference adjourns it will adjourn to meet again at two o'clock p. m. Conference then took up the consideration of the first question on the minutes, viz: Who are received on trial? And Philip J. Beswick, recommended from the Charleston district; Charles B. Davidson, recommended from the Indianapolis district; Daniel S. Elder, recommended from the Vincennes district, were admitted. Isaac Merrill, recommended from the Crawfordsville district, was not admitted. Whereupon conference adjourned.

At two o'clock p. m., conference met pursuant to adjournment and opened by Rev. James Havens by reading a portion of the Scripture, singing and prayer, the list was called, the journals read and approved and conference proceeded to business. Bishop Soule, in the chair, took up the third question on the minutes, viz: Who are admitted into full connection? And the candidates having been called forward, were in a most solemn and impressive manner admonished by Bishop Soule, and questioned as the discipline directs. After which the committee on examination having reported, the characters of Seth Smith, John Talbott, John L. Kelly, Lucian W. Berry, Cyrus Nutt, George W. Stafford, F. A. Conwell, James Hill, J. H. Hull, George Havens, J. J. Cooper, James Crawford, J. S. Barwick,

1 The widow of a traveling. superannuated, or supernumerary preacher was allowed one hundred dollars per year. The single preachers were allowed one hundred dollars each. Married preachers received an allowance of two hundred dollars. (Methodist Discipline, 1840 , pp. 169, 170.) 
were severally examined and passed and admitted and they were elected to deacon's orders, except L. W. Berry and J. J. Cooper, who, having been previously ordained, and being eligible, were elected to elder's orders. Wm. F. Wheeler, Elza Vanschoiack, Sandy Havens were continued on trial, to give them further time to make themseives acquainted with the studies required by conference. Hezekiah Smith was discontinued at his own request. William Wilson, William Campbell, Daniel F. Stright, Samuel K. Young were continued on trial. L. L. Allen was discontinued at his own request, in consequence of affliction. Henry Beharrall was discontinued at his own request. On motion, conference adjourned.

On Saturday morning, at half past eight o'clock, conference met pursuant to adjournment, and was opened by Rev. William Shanks, by reading a portion of Scripture, singing and prayer. The list was called and journals read and approved. Conference proceeded to business with Bishop Soule in the chair. On motion, the vote by which William Campbell was continued on trial was reconsidered, and he was discontinued at his own request, in consequence of ill health. On motion, the presiding elder, in whose district Isaac Merrill may reside, has leave to employ him, should he deem it necessary. Rev. John F. Wright, principal of the Western Book Concern, spent some time in making a verbal statement respecting the condition of the concern, and the necessity of prompt payment on the part of its debtors. Conference took up the consideration of local preachers, recommended to deacon's orders. Abner Keen, recommended from the Charleston district; Richard Hicks, Peter Hudson, Frederick Long, recommended from the Crawfordsville district; Edward White and Ezekial Johnson, recommended from the Connersville district; David Semons, recommended from Richmond district; Eli Rogers and John 
F. Truston, recommended from Logansport district; George Rumsey and Austin Fuller, recommended from South Bend district, and William D. Cox, from the Madison district, and John W. Holland, recommended from the Indianapolis district, were elected to deacon's orders. William Falkner, from Indianapolis district, and Mark Bruffer from Greencastle district, were not elected. A motion made to sit with closed doors on the examination and election of elders, was lost. The conference took up the consideration of local deacons, recommended to elder's orders, and Thomas Harget and John Kisling, local deacons, recommended from Madison district, were severally examined and elected to elder's orders. Samuel Barett, from Indianapolis district, having certified his belief and adherence to the doctrines and discipline of the Methodist Episcopal Church, was elected. Townsend Truslow was recommended from Indianapolis district, but on motion, his case was laid over. William Rector, recommended from Vincennes district, having certified to his belief in the doctrines and his adherence to the discipline of the Methodist Episcopal Church was elected. Elam Genung, recommended from the Greencastle district, was examined and elected. Williamson Terril, recommended from the Bloomington district, was examined and elected. Thomas B. Connelly, recommended from the South Bend district, was not elected. Gehial $\mathrm{H}$. Hard, from South Bend district, was elected. Townsend Truslow, having requested his representative to withdraw his recommendation, the conference gave permission to do so. Henry Brenton, recommended from the Indianapolis district, having been examined, gave assurance of his belief in the doctrines and his adherence to the discipline of the Methodist Episcopal Church, was elected to elder's orders. John A. Decker, from Vincennes district, was readmitted.

Conference resumed the consideration of the first 
question on the minutes, viz: Who are admitted on trial? John B. Demotte, recommended from the Crawfordsvilie district, was admitted. Elam Genung, recommended from Greencastle district, was admitted. Absalom Paris, recommended from Connersville district, was not received, but on motion, the presiding elder in whose district he may reside, has leave to employ him should he deem it expedient. Asbury Wilkinson, recommended from the Connersville district, was admitted. John L. Smith, recommended from the Richmond district, was admitted. James Black, recommended from Logansport district, was not admitted, but on motion the presiding elder, in whose district he may reside, shall have liberty to employ him, should he deem it necessary.

On Monday, half past eight o'clock a. m., conference met pursuant to adjournment, and was opened by Rev. A. Eddy, by reading a portion of the Scripture, singing and prayer. The list being called, the journals read and corrected, conference preceeded to business, Bishop Soule in the chair. On motion, conference resolved to attend the anniversary of the Preachers' Aid Society in the M. E. Church tomorrow at two o'clock. On motion, a committee of three was appointed, consisting of Henry S. Talbott, Allen Wiley and William Shanks, to estimate the table expenses of Bishop Roberts. Conference resumed the consideration of the first question on the minutes, viz: Who are admitted to trial? Colbreth Hall, recommended from Logansport district, was admitted. Charles W. Miller, recommended from South Bend district, was admitted. Morris Benton, recommended from Bloomington district, and Daniel McAntire, from Madison district, were admitted. George W. Shively, recommended from Charleston district, was not admitted, but on motion, the presiding elder in whose district he may reside, has liberty to employ him, if he deems it necessary. Nathan S. Worden, 
recommended from Charleston district, was admitted. John W. Mellander, recommended from Indianapolis district, was admitted. Freeman F. Sheldon, recommended from Vincennes district, was admitted. Robert H. Calvert, recommended from Crawfordsville, was admitted. Thomas Goodwin, recommended from Greencastle district, was admitted. John C. Crouch, recommended from Connersville district, was not admitted, but on motion, the presiding elder in whose district he may reside may, if necessary, employ him. Manlove Reid, recommended from Connersville district, was not admitted. On motion, the presiding elder in whose district John C. Crouch may reside, can, if he thinks expedient, employ him. Brenton Webster, recommended from Richmond district, was admitted. Samuel Smith, recommended from Logansport district, was admitted. Isaac M. Stagg, recommended from South Bend district, was admitted. W. D. Cox, recommended from Madison district, was not admitted. Wm. C. Smith, recommended from Indianapolis district, was admitted. Allen Skillman, recommended from Logansport district, was admitted. Solomon B. Knapp, recommended from South Bend district, was not admitted, but on motion, the presiding elder, in whose district he may reside, has leave to employ him, should he deem it expedient. On motion of Rev. Allen Wiley it was resolved that Alexander L. Miller be located in consequence of having absented himself from the state without giving the conference any information as to his intention of returning. F. M. Richmond, through his presiding elder, asked and obtained a location. James Scott, through his presiding elder, asked and obtained a superannuated relation to this conference. Asa Beck asked to have his relation changed from superannuated to supernumery, and a motion was made to reconsider the vote by which Brother Beck was continued in his superannuated relation, which was lost. The Bishop 
was called on to decide whether a supernumery preacher has his full claim on the circuit where he labors, irrespective of the service rendered by him? The Bishop decided that is not the present usage of the church to allow the full claim where full service has not be rendered. Resolved, that a committee of three be appointed to report on the benevolent operations of the Church in Indiana, and also to make such suggestions as in their opinion may be calculated, when adopted, to promote increased action in our various benevolent enterprises. On motion, conference adjourned.

Tuesday, at half past eight o'clock a. m., conference met pursuant to adjournment, and was opened by Rev. A. Wiley by reading of Scripture, singing and prayer. The list was called, the journals read and approved, and conference proceeded with business, Bishop Soule in the chair. The secretary presented the book which he was directed to purchase for the records of the conference, which was received and paid for by the members of the conference. Brother George Havens, through his presiding elder, asked and received a location. Brother John A. Brouse, through his presiding elder, asked to have his relation changed from effective to superannuated, and his request was granted. The stewards then made their report, showing the total amount of claims of the members of the conference to be $\$ 30,645.20$. Amounts received $\$ 21,818.38$, leaving a deficit of $\$ 8,826.82$. To meet which they have from fifth $^{2}$ collections $\$ 173.81$, from book corncern $\$ 600.00$, from chartered fund $\$ 73.00$, from conference collection $\$ 39.40$, which enabled the stewards to declare a dividend of ${ }^{3} 443 / 4 \%$ on deficits. The report was adopted

2 The fifth collection was so called to distinguish it from the regular four quarterly collections taken to support the active ministry. The fund went to the superamnuated ministry. (See Western Christian Adrocate, July 19, 1844, p. 55.)

3 There seems to be an error here in figuring out the per cent. 
and the funds distributed to the claimants. There being a surplus of $\$ 4.40$ and a gold watch seal, the stewards were directed to present the same to Brother Vredenburgh. The stewards also report $\$ 1.32$, which came into their hands after the formation of the report, which sum was voted into the hands of Brother J. Myers. The numbers in society were then taken and it was found that there has been an increase of 7,116 members during the past year. Conference then resumed the consideration of the first question on the minutes, viz: Who are admitted on trial? Whereupon John Kisling, recommended from the Madison district, was admitted. Martin J. Hofer, recommended from Madison district, was admitted. Eli C. Jones, recommended from Vincennes district, was admitted. On motion, the presiding elders in whose districts Wm. D. Cox and Manlove Reid may reside, shall have leave to employ them if expedient. Resolved, that it shall be the duty of those preachers in whose bounds superannuated preachers or widows, or orphans of preachers may reside to make special inquiry, concerning their circumstances, and, if orphans, whether they are receiving a proper education? And report the same to the next conference. A communication signed by $\mathrm{H}$. P. DeBruler, complaining that injustice had been done him by the quarterly conference of the Princeton circuit, was received. The communication was, on motion, referred to a committee of three, who shall have power to examine persons and papers, and report to this conference before the close of this session. Samuel C. Cooper, Enoch G. Wood and R. S. Robinson were appointed that committee. On motion, conference adjourned.

Wednesday, at half past eight o'clock a. m., conference met pursuant to adjournment, and was opened

If there were no other funds received than here enumerated the dividend declared was a little over 10 per cent. 
by Rev. Samuel C. Cooper by reading a portion of the Scripture, singing and prayer. The list was called, the journals read and approved, and the conference proceeded to business, Bishop Soule in the chair. The mission committee presented their report showing an appropriation for the support of missions, within the bounds of the conference, amounting to $\$ 905.00$ for the current year. The report was concurred in by Bishop Soule. The book committee presented their report, which was adopted. The committee to whom was referred the case of Brother DeBruler report that in their opinion the said DeBruler had no right to appeal to this body. The report was adopted. The financial committee reports the following resolution: "Resolved, that the principle laid down in the report of the financial committee of last year is the only one which can prove just and give general satisfaction." The report was adopted. The stewards reported that they were authorized to draw on the Preachers Aid Society of the Indiana annual conference for $\$ 409.69$, which was distributed as follows :

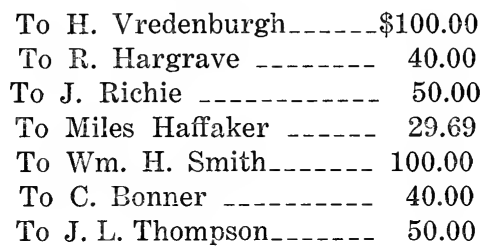

The above report was adopted. The committee to estimate the table expenses of Bishop Roberts reported the sum of $\$ 400.00$, which was adopted. The committee appointed at the last conference to have the moneys and donations for centenary purposes recorded in a proper book, reported that they have attended to the business assigned them, which book cost $\$ 4.38$. J. Soule presented his account for recording the names 
of the donors, and it was resolved that he be paid out of moneys which may have been or shall be collected for centenary purposes. The first annual report of the joint Board of Trustees and Visitors of the Indiana Asbury University was presented and accepted, and ordered to be printed in the Western Christian Advocate. The following preamble and resolutions were unanimously adopted: Whereas, Divine Providence has greatly prospered the Indiana annual conference, in her endeavors to establish a valuable institution of learning, and, whereas, said institution is greatly in need of a valuable library, chemical and philosophical apparatus, commensurate with her high destiny, and, whereas, it will need $\$ 20,000$ to procure such library and apparatus, and whereas, Bishop Soule expects to visit Europe in 1842, and he would be a suitable agent to aid in the purchasing of such part thereof as it will be necessary to purchase in Europe, therefore, be it resolved, that relying on Divine Providence, we mutually pledge ourselves to use our best endeavors to raise the said sum of $\$ 20,000$ before Bishop Soule sails for Europe. (Signed) Allen Wiley, C. W. Ruter. Resolved, that each preacher in the Indiana conference be requested to exert his influence to procure annually one or more suitable students for the Asbury University. (Signed) S. C. Cooper, Allen Wiley. Resolved, that the twenty-fifth day of December next, be set apart to be observed as a day of thanksgiving and praise to Almighty God for the mercies of the past year, especially for the unexampled increase in the membership of the church, and that we will recommend all our people to make on that occasion a missionary thank-offering. A. Eddy, W. W. Hibben. The committee, to whom was referred the peculiar situation of Brother Stiver, reports that it is inexpedient for this conference to give any advice in the case, in which report the conference concur. The agent for the uni- 
versity reported, that since the 25 th day of September, 1839, he has added to the funds of the institution $\$ 6,702.25$, and that the whole amount of cash and property passed through his hands since the same date is $\$ 18,696.40$. On motion, conference adjourned, to meet again at two o'clock p. m. N. B. The following resolution passed in the forenoon was omitted: Resolved, that each preacher be required as early as convenient in the ensuing year to furnish his presiding elder with a list of all the postoffices in the bounds of his work, and that each presiding elder furnish the book agents at New York with said list. William V. Daniel, S. T. Gillett.

Two o'clock p. m., conference met pursuant to adjournment and was opened in the usual manner by Rev. E. G. Wood, Bishop Soule in the chair. A communication was received from the Indianapolis Branch Bible Society in relation to the claims of the Bible cause and the necessity of patronizing it. On motion, resolved, that we approve of the resolution presented by the Bible Society of Indianapolis, and that we will carry it into effect as far as our peculiar economy will permit.

On motion, conference proceeded to elect nine visitors to the Indiana Asbury University, for the present year, and a committee of the three was appointed to retire to another room and count the votes, it was ascertained that A. Wiley received seventy-three votes, W. H. Goode sixty-nine, A. Eddy sixty-six, C. W. Ruter sixtyfour, E. R. Ames fifty-five, S. C. Cooper forty-seven and A. Wood thirty-five, J. L. Belotte thirty-four, J. C. Smith thirty and these brethren were announced by the president as being duly elected. Conference then proceeded to fix by ballot, the place of the next annual session, and Terre Haute was chosen as the place, and the time appointed by the Bishop, is October 20, 1841. On motion, resolved, that a vote of thanks be tendered 
to the citizens of Indianapolis for their kind hospitality shown toward the preachers during their present session, and that it be announced in the public congregation by the preacher who may fill the pulpit in this charge on next Sabbath. Resolved, that a vote of thanks be tendered by this conference to the several pastors and congregations who have kindly tendered their respective churches for the occupancy of the ministers of this body. Resolved, that the examination at the close of the first year of such as have one year on trial be dispensed with and that the granduates be examined on the full course, recommended at the close of the second year. For the purpose of infusing more energy and producing greater unanimity of action in our benevolent and literary enterprises: It is ordered by the Indiana annual conference that two general annual collections be made in all our congregations. The first to be made during the months of December, January and February for the support of missions. The second to be made during the months of April, May and June, for the aid of our university. The fund to be applied under the direction of the conference, to the purchase of a library, chemical and philosophical apparatus. It is also directed by the conference that each presiding elder preach a special sermon on each of these subjects annually in each station, and circuit in his district, and that he also see that each preacher make collections as above specified. It is recommended to the preachers as the best method of collecting funds, not to depend on public collections alone, but in their pastoral visits to bring the subject before the members and friends of the church, individually. That by this means the entire strength of the church may be concentrated upon the great object we desire to accomplish, viz: the religious and intellectual improvement of the whole community. Resolved, that the book containing the record of donations to the centenary fund be placed in the hands of 
President Simpson to be laid up in the archives of the Indiana Asbury University. Resolved, that the second Friday in January be observed as a day of fasting and prayer for the prosperity of Zion generally and especially for the revival of the work of God in the bounds of this conference. The bishop then proceeded to close the conference by an appropriate farewell address and by singing the hymn, commencing with the words: "And Let Our Bodies Part," and by prayer. The Bishop then read out the appointments for the ensuing year.

(Signed) JOSHUA SOULE.

E. R. Ames, Secretary.

\section{APPOINTMENTS FOR 1840.}

Madison District.

Calvin W. Ruter, Presiding Elder.

Madison Station-Joseph Marsee.

Canaan-Constant B. Jones.

Vevay_James Jones, Daniel McIntire.

Rising Sun-Samuel T. Gillet, Thomas Goodwin.

Lawrenceburg-John C. Smith.

Wilmington-Francis H. Cary, Washington Mulick. Manchester-Richard Hargrave, George W. Baker.

Varsailles-Seth Smith, Jesse C. Harbin.

Paris-Amos Bussey, Hayden Hays.

Indiana German Mission-John Kisling, M. J. Hofer.

Charlestown District.

Enoch G. Wood, Presiding Elder.

New Albany-William V. Daniel.

Corydon-Thomas S. Gunn, Edward Oldham.

Greenville-George K. Hester, Nathan S. Worden.

Salem-Emmons Rutledge, G. W. Ames.

Charleston-Charles Bonner, Thomas J. Doyle.

Lexington-J. Crawford, Peter R. Guthrie. 
Jeffersonville Station-Fernandes C. Holliday. Rome-Eli C. Jones.

\section{Indianapolis District.}

James Havens, Presiding Elder.

Indianapolis Station-William H. Goode.

Noblesville-Isaac Crawford, Freeman F. Sheldon.

Mooresville-James Hill, J. S. Barwick.

Franklin-Wm. T. Smith, Jacob Myers.

Shelbyville-Henry S. Dane, John V. R. Miller.

Rushville-George W. Bowers.

Knightstown-Lucien W. Berry.

Greenfield-John B. Birt, John W. Mellander.

Pipe Creek-John L. Kelly.

\section{Vincennes District.}

Henry S. Taibott, Presiding Elder.

Evansville-Anthony Robinson.

Mount Vernon-Thomas Ray, Daniel S. Elder.

Princeton-John Daniel.

Newburg-John A. Decker.

Rockport-William Knowles.

Vincennes-John Kerns.

Washington-Stephen Ravenscroft.

Carlisle-Isaac McElroy.

Lebanon-Samuel H. Rogers.

Knox-William Bratton.

\section{Crawfordsville District.}

Thomas J. Brown, Presiding Elder.

Lafayette-Amasa Johnson.

Dayton-William Wilson.

Frankfort-Ancil Beach, John B. Demott.

Covington-Enoch Wood, Jared B. Mershon.

Newtown-Allen D. Beasley, R. H. Culvert.

Crawfordsville Station-Ebenezer Patrick. 
Crawfordsville Circuit-Daniel Demott, Wesley Dorsey.

Danville-Thomas Bartlett.

Augusta-Miles Huffaker.

Alamo-John Edwards.

Greencastle District.

Allen Wiley, Presiding Elder.

Greencastle Station-Hawley B. Beers.

Greencastle Circuit-Isaac Owen, Jacob Miller.

Putnamville-Jonas L. Belotte.

Rushville-Elam Genung.

Rockville-Silas Rawson.

Terre Haute Station-John S. Bayless.

Terre Haute Circuit-Cornelius Swank, Ezra L. Kemp.

Newport-William H. Smith, Rosetter C. Rowley.

Indiana Asbury University-Matthew Simpson, President; Cyrus Nutt, Professor; Samuel C. Cooper, Agent.

\section{Bloomington District.}

John Miller, Presiding Elder.

Bloomington Station-Philip May.

Springville-John Talbott.

Bedford-Charles M. Holliday.

Brownstown-William Meginnes.

Columbus-Benjamin T. Grifith, Lealdas Forbes.

Spencer-Jacob M. Stallard.

Paoli-Draper Chipman, Morris Benton.

Brown Mission-Thomas Spilman.

Richland Mission_James R. Williams.

Leesville-George W. Walker.

Connersville District.

Augustus Eddy, Presiding Elder. 
Connersville Circuit-Elijah Whitten, Asbury Wilkinson.

Centerville-Miltiades Miller, Landy Havens.

Richmond-Joseph Tarkington.

Liberty-John Keiger.

Brookville-William W. Hibben, Charles B. Davidson.

Greensburg-G. C. Beeks.

Milroy-Lewis Hurlbert, Isaac Kelso.

Scipio-Lemuel L. Reeves.

\section{Winchester District.}

Robert Burns, Presiding Elder.

Winchester-John H. Bruce, J. L. Smith.

Portland-Barden H. Bradbury.

Munceytown-John S. Donaldson, Brinton Webster.

Marion-John H. Hull.

Andersontown-Daniel F. Stright.

Pendleton-John W. Sullivan.

Bluffton-Joseph Ockerman.

Newcastle-Joseph Carter.

\section{Logansport District.}

George M. Beswick, Presiding Elder.

Logansport Circuit-Richard S. Robinson.

Peru-John F. Truslow.

Auburn-Samuel Smith.

Fort Wayne-Francis A. Conwell.

Delphi-Joseph White, Philip J. Beswick.

Independence-Joseph J. Cooper, Colbreth Hall.

Monticello-Jacob Colclazer, Samuel Reed.

Iroquois, Walter L. Huffman.

Rochester-George W. Stafford.

South Bend District.

Aaron Wood, Presiding Elder. 
South Bend Station-William M. Fraley.

Mishawaka-Warren Griffith.

Goshen-Wade Posey, Allen Skillman.

Lagrange-Enoch Holdstock, Charles W. Miller.

Haw Patch-Ezra Van Schoiack.

Laporte-Zachariah Games, William F. Wheeler.

Valparaiso-William J. Forbes.

Warsaw-Samuel K. Young.

Plymouth-Isaac M. Stagg.

Terrecoupee-George M. Boyd.

Edward R. Ames, secretary of the Missionary Society of the Methodist Episcopal Church.

James S. Harrison, transferred to Michigan conference.

John W. Weakley, transferred to Ohio conference.

JOURNAL of the tenth annual session of the Indiana Conference, held in the Methodist church in Terre Haute, October 6, 1841.

Wednesday morning, 9 o'clock. Conference met according to appointment, and was opened by Bishop Roberts, by reading the second chapter of the second Epistle of Timothy, and by singing and prayer. The list was then called by Brother Patrick, the assistant secretary of last conference, and the following members were found to be present, viz.: C. W. Ruter, E. G. Wood, James Havens, C. S. Talbott, T. J. Brown, Allen Wiley, John Miller, Augustus Eddy, Robert Burns, G. M. Beswick, Aaron Wood, Joseph Marsee, Thomas Bartlett, C. B. Jones, James Jones, J. C. Smith, W. V. Daniel, Charles Bonner, F. C. Holliday, W. H. Goode, Isaac Crawford, H. L. Dane, John Kiger, W. J. Forbes, William Knowles, L. W. Berry, Anthony Robinson, Thomas Ray, John Daniel, John Kearns, Isaac McElroy, Amasa Johnson, A. Beach, Enock Wood, Ebenezer Patrick, Daniel DeMotte, Thomas Bartlett, Isaac Owen, J. L. Belotte, J. S. Bayless, Cornelius Swank, 
E. L. Kemp, M. Simpson, C. Nutt, S. C. Cooper, C. M. Holliday, J. B. Birt, Emmons Rutledge, G. M. Boyd, Philip May, William McGinnis, W. W. Hibben, G. C. Beeks, Lewis Hurlbert, L. L. Reeves, J. H. Bruce, J. W. Sullivan, R. L. Robinson, Joseph White, Jacob Colclazer, Zachaniah Games, David Stiver, William M. Daily, J. A. Brouse, H. Vredenburgh, Borroughs Westlake, S. P. Gillett, John Edwards Jacob Miller, Francis H. Cary, Jacob Myers, G. W. Bowers.

The conference then proceeded to elect a secretary by ballot, and upon counting the votes Matthew Simpson, having received a majority of all the votes, was declared duly elected, and on motion of Brother Ruter, Ebenezer Patrick was appointed assistant secretary.

On motion of Brother Cooper the aisle was fixed upon as the bar within which all the members were expected to sit. On motion of Brother Wiley the hour of assembling in the morning was fixed at eight o'clock, and of adjournment at twelve.

On motion of Brother Ruter, Allen Wiley and J. S. Bayless were appointed a committee to select the preachers and superintend the religious services during the conference, and on suggestion of Brother Wiley, John Daniel was added to said committee.

The conference then proceeded to the election of stewards and, upon motion of Brother Ruter, it was resolved that the election should be by a plurality of votes, whereupon, on counting the votes, S. C. Cooper, J. A. Brouse and Cyrus Nutt having the highest number of votes, were declared duly elected, but the conference having released Brother Cooper at his own request, William V. Daniel being the next highest was appointed in his place.

On motion of Brother Wiley, the conference proceeded to elect a committee of three to disburse the funds received from the Preachers' Aid Society, in accordance with a provision in the constitution of said 
society, and on motion of Brother E. G. Wood the choice was determined by a plurality of votes, whereupon Allen Wiley, J. C. Smith and James Havens were declared duly elected.

On motion of Brother Ruter, the by-laws adopted at the first session were read and after having added to them the resolution adopted at the Lawrenceburgh conference, in reference to sitting with closed doors during examination of character, they were adopted as the rules of this conference.

On motion of Brother Cooper a committee was appointed to examine the journals, as transcribed by order of last conference, and Isaac Crawford, L. W. Berry and S. T. Gillett were appointed said committee.

On motion of Brother Wiley, F. C. Holliday, George Bowers and W. W. Hibben were appointed a committee on the Eastern Book Concern, and thereupon the Bishop presented a letter and exhibit from the book agents at New York, which was read and filed among the papers of the conference, and the accounts were referred to the committee.

John C. Smith, Lucian W. Berry and Samuel T. Gillet were appointed a committee to prepare memoirs of our brethren who have died during the year.

On motion it was resolved that S. C. Cooper be a committee to receive any moneys that may have been collected for apparatus and library of the university according to a resolution of last session.

On motion of Brother A. Wood it was resolved that when conference adjourns it will adjourn to meet at 2 o'clock p. m.

The second question on the minutes was then taken up, viz.: Who remain on trial? And the characters of Philip Beswick, Daniel S. Elder, Elam Jenung, John L. Smith, Charles W. Miller, Daniel McIntire, John M. Millander, Robert H. Colvert, Button Webster, Isaac M. Stagg, Allen Skilman, Martin J. Hofer, 
Charles B. Davidson, John B. Demotte, and Asbury Wilkeson were severally examined and passed, and they were continued on trial. Colbeth Hall was discontinued at his own request.

The hour of adjournment having arrived, the session was closed with prayer by Reverend Belotte.

Wednesday afternoon, 2 o'clock. Conference met pursuant to adjournment, and was opened by reading, singing and prayer by Brother Wiley, and after the roll was called and the journal read and approved the bishop introduced to the conference William C. Larrabee, formerly of the Maine conference, and who is now transferred to this conference, and is one of the professors in the Asbury University, and he accordingly was invited to take his seat as a member of this conference.

The bishop then presented a letter from Brother J. B. Finley, which, on motion of Brother Wiley, was referred to a committee, and Allen Wiley, Augustus Eddy and Aaron Wood were by the chair appointed said committee.

The second question on the minutes was resumed, and the character of Morris Benton, Nathan S. Worden, Thomas A. Goodwin, Samuel Smith, William C. Smith, John Kisling and Eli C. Jones were severally examined and passed, and they were continued on trial. Freeman F. Sheldon was discontinued at his own request.

The fourth question on the minutes was then taken up, viz.: Who are the deacons? And the characters of Seth Smith, Cyrus Nutt, Francis A. Conwell, James Hill, Joseph S. Barwick, John Talbott, John L. Kelly, George W. Stafford, John H. Hull and James Crawford were severally examined and passed.

The fifth question of the minutes was taken up, viz.: Who have been elected and ordained elders this year? And the characters of Samuel T. Gillet, John 
Edwards, Jacob Miller, Francis H. Cary, John Kiger, Silas Rawson, Wade Posey, John B. Birt, William J. Forbes, Jacob Myers and George W. Bowers were severally examined and passed, and they were elected to Elders Orders.

On motion Isaac Kelso was located, because he has neither filled or attempted to fill his appointment for the past two years.

On motion of Brother Wiley, Silas Rawson was supplied in a superannuated relation, on account of ill health.

On motion, conference adjourned until tomorrow morning at 8 o'clock, and was closed with prayer by Rev. Daniel.

Thursday morning, October 7, 1841. Conference met pursuant to adjournment and was opened by reading, singing and prayer by Rev. Ruter. After the roll was called, and the minutes were read and approved, Brother Swormstedt, one of the Western Book Agents, addressed the conference on the business of the book concern.

The stewards were then permitted to call upon the members of the conference for their claims and receipts, and also for the amount of the fifth collection.

At the suggestion of the bishop conference voted to draw upon the book concern for seven hundred dollars, and upon the chartered fund for sixty-nine dollars, and at the suggestion of Brother Wiley, the draft was ordered upon the Preachers' Aid Society for four hundred and fifteen dollars.

The third question of the minutes being taken up, viz.: "Who are admitted into full connection?" The candidates were called forward and after having been questioned, as the discipline directs, were for a few moments solemnly and impressively addressed by the bishop, and the committee of examination having reported in each case, the characters of Peter R. Guthrie, 
Edward Oldham, James R. Williams, Rosetter C. Rowley, Walter L. Hoffman, John S. Donaldson, Enoch Holdstock, William Wilson, George W. Ames, Draper Chipman, J. F. Truslow, Lealdes Forbes, George W. Baker, Wesley Dorsey, Barden H. Bradbury, Samuel Reed and William Wheeler were severally examined and passed, and they were admitted into full connection, and elected to Deacons' Orders, except J. F. Truslow and Barden H. Bradbury who had previously been ordained.

On motion of Brother A. Wood the session was prolonged to finish the third question.

Joseph Cartier and Ezra Vanschiack were discontinued at their own request,, made through their Presiding Elders.

The characters of Haden Hays, Thomas J. Doyle, Washington Malick and William Bratton were examined and passed, but not having been present at examination they were on motion continued on trial.

The characters of Hayden Hays, Thomas J. Doyle, $\mathrm{K}$. Young were examined and passed and on motion they were continued on trial to complete their studies.

The character of Joseph Ockerman was examined and passed but fears being entertained in reference to his health he was, on motion, continued on trial.

The characters of George W. Walker and Daniel F. Stright were examined and passed and they were admitted into full connection, and having been ordained deacons for two years, they were elected to Elders' Orders.

The name of Samuel H. Rogers being called Brother Talbott, his presiding elder, reported that he had labored with great acceptability during part of the year, but being attacked with disease, after having suffered much affliction, he had recently died in peace.

The name of Joseph J. Cooper having been mis- 
placed on the minutes, his character was examined and passed.

J. V. R. Miller and Landy Havens having been absent when the Bishop addressed the candidates, were now called and questioned, and their characters were examined and passed, and they were admitted into full connection and elected to Deacons' Orders.

On motion the conference adjourned until tomorrow morning and was closed with prayer by Brother Dane.

Friday morning, October 8, 1841. Conference met pursuant to adjournment, and was opened with reading, singing and prayer by Rev. S. C. Cooper.

On motion of Brother Eddy, calling the roll was dispensed with during the remainder of the session.

The minutes of yesterday were read and approved, and Brother Swormstedt again addressed the conference and presented the exhibit of the Western Book Concern which was filed among the papers of this conference. The stewards then made another call for the fifth collection.

The following resolution was presented by Brother Eddy :

"Resolved, That the Superintendent be requested to revise the course of study for this conference.
A. EDDY, E. G. WOOD.

And after a brief discussion, it was withdrawn by the mover.

On motion of Brother A. Wood, it was resolved that when conference adjourn it will adjourn to meet at two o'clock this afternoon, to attend to certain appeals.

Brother J. C. Smith presented the parchment of Thomas P. Jones as local deacon, who had surrendered it into his hands, when certain statements were alleged against him, which he declined to meet, and the 
parchment was filed among the papers of the conference.

The fifth question of the minutes being resumed, viz.: "Who have been elected and ordained elders this year?" The name of William Knowles having been called, it was resolved that his character pass, and that he receive such admonition as the bishop may think fit.

The name of H. B. Beers having been called it was on motion resolved that a committee of five be appointed by the chair to consider any objections which may be made against him.

The character of Emmons Rutledge was examined and passed and he was elected to Elders' Orders.

The resolution continuing Brother Ockerman on trial was on motion of Brother Beswick reconsidered, and he was admitted into full connection and elected to Deacons' Orders.

The first question on the minutes was then taken up, viz.: "Who are admitted on trial?" And the following brethren were recommended and admitted on trial, viz.: Charles Mapes, from the Madison district; Jesse Sparks, from the Crawfordsville district; Williamson Tyrrill, from the Bloomington district, and John Bradshaw, from the Winchester district.

George Havens was recommended from the Indianapolis district and having previously been a member was readmitted.

James D. Templin was recommended from the Indianapolis district but was not received, and William $K$. Knale was recommended from the Charlestown district and his case was laid upon the table for further consideration.

Brother Whitter presented the parchments of John W. F. Tevis as deacon and elder, and they were filed among the papers of the conference.

The chair announced C. W. Ruter, A. Wood, J. Mil- 
ler, R. S. Robinson and W. V. Daniels as the committee on the case of Brother Beers.

The time of adjournment having arrived, conference was closed with prayer by Brother Marsee.

Friday afternoon, October 8, 1841. The conference was opened according to adjournment with prayer by Brother Burns and the minutes of the morning were read and approved.

The conference went into an investigation of an appeal taken by William Hunt, a local elder in the Winchester circuit, from the decision of the quarterly meeting conference, by which he had been expelled from the Methodist Episcopal church. The appellant having come forward, Brother Burns, the presiding elder before whom the trial took place, presented a copy of the minutes of the trial, which was read before the conference and filed among its papers. The appellant then addressed the conference, giving the grounds of his appeal, admitting the truth of the first charge on which he was tried, but alleging that he was sustained by facts. Whereupon, after due deliberation, the following resolution was presented, viz.: "Resolved, That the decision of the quarterly meeting conference of the Winchester circuit, by which William Hunt, a local elder in the Methodist Episcopal church, was expelled from said church, be and is hereby reversed. Allen Wiley, James Scott." And the resolution was adopted almost unanimously by a rising vote.

The first question of the minutes was resumed and the following brethren were recommended and received, viz.: Orange V. Lemon, from South Bend district; David Crawford, from Indianapolis district; James Corwin, from Vincennes district; James $H$. Newland, from Bloomington district; Hezekiah Smith, from Winchester district; Alfred B. Nesbit, from Vincennes district; Jacob Whiteman, recommended from Charleston circuit, Ohio; Absalom Paris, from Green- 
castle district, and Jacob Bruner, from Bloomington district.

William H. Knale, whose case was laid over, and Eli Rogers, from the Logansport district, were not received, but on motion their elders have liberty to employ them if necessary.

Samuel Brenton, recommended from the Crawfordsville district, having previously been a member, was readmitted.

E. F. Remington was recommended from the Madison district but was not received.

On motion of Brother Eddy conference adjourned until tomorrow morning, and was closed with prayer by Brother Kearns.

Saturday morning, October 9, 1841. Conference was opened according to adjournment with reading, singing and prayer by Brother Eddy.

Some remarks were made concerning the book concern, by the agent, and several visiting brethren were introduced by the bishop.

On motion the Rev. Mr. Fitch, Bible agent, who had previously been introduced to the conference and who had requested opportunity to address the conference, was requested to give his address on Monday morning.

The committee on the transcription of the journals, by Brother J. Crawiord, the chairman made report as follows, viz.: "Terre Haute, 9th October, 1841. The committee appointed to examine and compare the journals of the former sessions of this conference, beg leave to report, that in examining the new journal, they have found the mechanical execution and orthography good and highly creditable, but on carefully comparing it throughout with the original, they have found numerous omissions, insertions and alterations in the language, in some instances improving, but in others changing the sense. The most material omissions are the report on education, and the printed ex- 
hibits of the book concern, and some resolutions on different subjects. Your committee have not deemed themselves authorized to make corrections, but herewith submit a statement of eighty-one errors, with the page and line where they occur, all which is respectfully submitted."

\section{J. CRAWFORD, L. W. BERRY, SAMUEL P. GILLET.}

Which report, together with the list of corrections, was laid upon the secretary's desk. A motion was made to adopt the report, and on motion of Brother Wood the subject was laid upon the table.

The first question on the minutes was resumed, and the following persons were recommended and received, viz.: Henry H. Bradley, from the Winchester district; Samuel C. Swayne, from the Winchester district; Milton Mahen, Horatio N. Barnes and James Black, from the Logansport district, and John C. Medsker and Elijah S. Blue, from the South Bend district.

On motion of Brother Cooper, the case of James D. Templin, who was not received, was reconsidered, and after deliberation he was received on trial. Eventus Doud, recommended from the Logansport district, was readmitted.

The recommendations of local preachers to Deacons' Orders were now taken up and the following brethren were elected to Deacons' Orders, viz.: Harvey Moss, John Ruby and Dennis Kearsey (a colored man), from the Madison district; John L. Smith, John W. Bradshaw and Stephan Norman, from the Winchester district; Thomas J. Doyle and Peter Bottorff from the Charlestown district; Elijah Sewell, Obadiah Tincher, John Hancock and Thomas B. Caywood, from the Crawfordsville district; Mark Bruffe and Alexan- 
der Surbaugh, from the Greencastle district; and John Sutcliffe, from the Connersville district.

Pleasant E. Royse was recommended from the Charlestown district, but was not elected. Michael Johnson was recommended from the Bloomington district, but was not elected.

The examination of applications for Elders' Orders was commenced, and the following persons were recommended and elected as elders, viz.: Robert Carron, from the Madison district; Samuel Brenton, from the Crawfordsville district; Samuel H. Dickerson, from the Greencastle district, and Robert Harrison, from the South Bend district. Elijah E. Barrett was recommended from the Winchester district, but owing to constitutional difficulties he was not elected.

Brothers Beswick and Burns were excused from attendance, to transact some necessary business. Absence was granted to Brothers A. Wood and E. G. Wood for the afternoon session, and to Brother Walker for the remainder of the session.

The committee, to whom the case of Brother Beers was referred, reported as follows: "We, the committee to whom the case of Brother Beers was referred for investigation after examining the evidence procurable in the case, report that in their judgment the difficulty arose entirely from misunderstanding between the parties and that nothing has occurred to implicate the Christian or ministerial character of Brother Beers. C. W. Ruter, chairman; William V. Daniels, secretary." Whereupon, on motion of Brother Thompson, the report was adopted and the character of Brother Beers being passed, he was elected to EIders' Orders.

The vote given in the case of Brother Ravenscroft was, on motion of Brother Dane, reconsidered, and he was admitted into full connection, and elected to Deacons' Orders. 
The hour of adjournment having arrived, on motion it was resolved that conference meet again at two o'clock this afternoon, and the session was closed with prayer by Brother Thompson.

Saturday afternoon, October 9, 1841. Conference was opened pursuant to adjournment, with reading, singing and prayer by Brother Havens.

The following resolution was then presented: "Resolved, That a committee of three be elected to estimate the table expenses of Bishop Roberts for the current year. C. W. Ruter, G. M. Beswick." Which being put by the secretary was unanimously adopted, and Allen Wiley, C. W. Ruter and A. Eddy were nominated and appointed said committee.

The committee to whom was referred the communication from Brother J. B. Finley, reported as follows, viz. :

"The committee to whom was referred the address of Brother J. B. Finley to this conference, on the subject of publishing a social and domestic library at our book room in Cincinnati, have had the same under consideration, and beg leave to report that in our opinion such a publication would be of great importance to our Western country in eliciting the talents of our writers, and the diffusion of useful knowledge among the people. But your committee are not in possession of sufficient data to decide whether it would be expedient to proceed immediately in this enterprise, especially in view of the depressed state of the pecuniary affairs of our country. The committee therefore beg leave to offer the following resolutions:

" Resolved, That in the opinion of this conference such a publication is desirable if suitable works can be obtained.

" 'Resolved, Secondly, That we recommend such a publication at our Western book room, provided it can be done without pecuniary loss to the concern. 
And after some deliberation and discussion the report and resolutions were adopted.

The following resolution was then presented:

"Resolved, That our venerable and beloved superintendent, Bishop Roberts, be and is hereby requested at his first convenient opportunity, to sit for his portrait, and that the preachers of this conference be permitted to defray the expense which may accrue in obtaining such portrait. C. W. Ruter, G. W. Ames." Which being put by the secretary was adopted by a rising vote.

The examination of the characters of elders was recommended and Brothers Ruter, Talbott, Brown, Wiley, Eddy, Burns, Havens, Miller and Beswick gave an account of their several districts, informing us of the work of God during the year as well as of their own personal experience, which was of a most gratifying character, and the season thus spent was one of deep and serious feeling-and their characters were examined and passed.

The report on the journals was on motion taken up, and the following resolution was then presented, viz.:

"Resolved, That a committee of three, to consist of E. R. Ames, Cyrus Nutt and H. B. Beers, be and they are hereby appointed to review, compare and correct the new journal, and report as soon as practicable to the conference. S. C. Cooper, Allen Wiley." Which resolution was adopted.

Brother Wiley suggested that expenses had accrued for the purchase of a book, and recording centenary contributions, on motion of Brother Cooper it was resolved that these expenses be met out of any centenary monies now on hand.

On motion conference adjourned to meet on Monday morning, and was closed by prayer by Brother Stiver.

Monday morning, 8 o'clock, October 11, 1841. Con- 
ference met pursuant to adjournment and was opened with reading, singing and prayer by Brother Kearns.

The journals were then read and approved, and on motion leave of absence for the remainder of the session was granted to Brother Forbes and Brother Truslow.

The time having arrived, which was set for hearing the address of Rev. Mr. Fitch, agent of the bible society, and he not appearing, on motion the conference proceeded to the regular business of examining the characters of elders and the characters of Joseph Marsee, Constant B. Jones, James Jones, John C. Smith, William V. Daniels, Richard Hargrave, Amos Bussy, William G. Good, Isaac Crawford, Henry S. Dane, Lucian W. Berry, Anthony Robinson, Thomas Ray and John Daniel were examined and passed.

The character of Jesse C. Harbin was examined and passed, and he was placed in a superannuated relation.

The character of John A. Decker was examined and passed and he was placed in a supernumerary relation.

The Rev. Mr. Fitch, the Bible agent, was now permitted to address the conference on the subject of Bible societies, and William V. Daniels, Joseph Marsee and John C. Smith were appointed a committee to take the subject into consideration and report to this conference.

Enoch G. Wood and Aaron Wood gave an account of the work in their districts and their characters were examined and passed.

The characters of the following brethren were examined and passed, viz.: Charles Bonner, F. C. Holliday, John Kearns, Isaac McElroy, Amasa Johnson, Ariel Beach, Enoch Wood, Jared B. Mershen, Allen D. Beasley, Ebenezer Patrick, Daniel Demotte, Thomas Bartlett, Miles Huffaker, Isaac Owen, J. L. Belotte, John S. Bayless, Cornelius Swank, Ezra L. Kemp, M. 
Simpson, S. C. Cooper, C. M. Holliday, Philip May, William McGinnis, Jacob M. Stallard, Thomas Spilman, Eiijah Whitten, Miltiades Miller, Joseph Tarkington, Wiiliam W. Hibben, G. C. Beeks, Lewis Hurlbert, Samuel S. Reeves, John H. Bruce, John W. Sullivan, R. S. Robinson, Joseph White, Jacob Colclares, William M. Fraley, Warren Griffith, Zachariah Games, George M. Boyd and Edward R. Ames.

The characters of William $H$. Smith and Benjamin T. Griffith were examined and passed and they were placed in a superannuated relation.

The characters of Thomas S. Gunn and George $\mathrm{K}$. Hester were examined and passed and they were granted a location.

The secretary was then permitted to read an abstract of numbers, Sunday school, etc., and after conference had been prolonged to permit him to finish the reading, the session was closed with prayer by Brother Huribert.

Tuesday morning, October 12, 1841. Conference was opened at the usual hour with reading, singing and prayer by Brother A. Wood, and the secretary not being present, Brother Swormstedt was permitted to address the conference, after which the minutes were read and approved and the house proceeded to business.

The following resolution was then presented, viz.: "Whereas, The premature marriage of young ministers, embarrasses the appointing power, burdens the fields of labor, with much additional expense, and in most cases retards the improvement of the preachers and thereby renders them less useful; therefore, Resolved, that this conference, in future, will discontinue any preacher who marries within the period of his probation.

ALLEN WILEY, E. G. WOOD." 
Which by the vote of the Conference was not sustained.

The following report was then submitted: "The committee appointed to estimate the table expenses of Bishop Roberts, have had the same under consideration, and have fixed the sum at four hundred dollars.

ALLEN WILEY,

C. W. RUTER,

A. EDDY."

October 9, 1841.

On motion of Brother Holliday, it was resolved that the preachers in charge of the circuit where Sister Rogers may reside, be requested to dispose of such part of the books received from the book concern as shall meet his liabilities to said concern.

The committee on memoirs reported a sketch of the life of Brother Williams which was adopted and handed to the bishop.

The following resolution was presented, viz.:

"Whereas, We regard the Indiana Asbury University as destined to exert an extensive and most salutary influence on the religious, moral and literary character of the community throughout our state; and

Whereas, we believe the interests of the university would be promoted by such a course; therefore

Resolved, That we respectfully request the trustees of the university to make such arrangements as will allow President Simpson an opportunity of spending next summer, or at least a part of it, in traveling throughout the state, for the purpose of extending his acquaintance among the people, and of promoting the interests of the university in such way as he may judge expedient.

Resolved, That the secretary be directed to lay a copy of this resolution before the board of trustees.
E. R. AMES,
C. W. RUTER." 
Which resolution was adopted.

The report of the mission committee was then presented by Brother Ruter and was adopted.

The examination of the characters of the superannuated preachers was then taken up, and the character of J. L. Thompson was examined and passed and he was continued in a superannuated relation, and the following resolution was adopted:

"Resolved, That Brother Thompson have liberty to remove to the west if he thinks proper so to do.

$$
\begin{aligned}
& \text { S. C. COOPER, } \\
& \text { C. W. RUTER." }
\end{aligned}
$$

'The character of James Scott was examined and passed and his relation continued, and on motion of Brother Cooper he was granted leave of absence for the remainder of this session.

The characters of William Shanks, John A. Brouse, Hackaliel Vredenburg and Asa Beck were examined and passed and they were continued in their relation.

The character of David Stiver was examined and passed, and he was continued in his relation, he informing the conference that for next year he would not be a claimant on its funds.

The character of Burroughs Westlake was examined and passed and he was made affective.

The character of John Richie was examined and passed and on motion his relation was changed from that of superannuated to supernumerary, and on motion it was resolved that Brother Ritchie be requested to locate at the next conference.

On motion, resolved, that the secretary be directed to furnish Brother Ritchie a copy of this resolution.

On motion it was resolved that when conference adjourns it adjourn to meet at 2 o'clock this afternoon, to consider the case of Brother Daily, and the session was closed with prayer by Brother J. Crawford. 
Tuesday afternoon, October 12, 1841. Conference was opened by reading, singing and prayer by Brother E. G. Wood, and the minutes being read, they were approved, with the exception that the following resolution passed in the morning session had been omitted:

"Resolved, That we highly approve the manner in which the Ladies' Repository has been thus far conducted, that it is fuliy calculated to meet the wishes of all ladies and gentlemen of intelligence and enlightened moral taste, wherever it is circulated, and that we think it worthy a still more extensive patronage. 2 d. That we will use our best endeavers to increase, within our respective charges the subscription list, to the ladies' repository, at the same time not forgetting nor neglecting the interests of the Western Christian Advocate, and other periodicals of our church.

C. W. RUTER,

S. C. COOPER."

Tuesday afternoon, October 12, 1841. The case of William M. Dailey being the order of the afternoon, Brother Havens as presiding elder, presented the minutes of the investigation had before him, by which it appeared that he had been cited before a committee, consisting of Brothers Whitten, Myers, J. Crawford, Berry and Birt, to answer the following charge: "For unministerial and unchristian intimacy with a certain Mrs. Defrees, a married woman. Specification first. For imprudently frequenting her room. Specification second. Laying your arms around her and kissing her in the absence of company." And after testimony presented and defense made, he had been suspended until this session of the conference. The minutes of said investigation are filed with the conference papers and marked No. 1; and accompanying them a paper containing his written defense before said committee marked No. 2 ; both of which are in- 
dorsed by the secretary with the date of their being filed. Which papers being presented and read, Brother Daily was called upon to make his plea to the charges, as by the decision of the chair, the case now came up on its merits. Whereupon he plead that he was guilty of imprudence, but not guilty of any crime sufficient to exclude from the kingdom of grace and glory, and referred to his plea before the committee contained in the minutes as containing the words he desired to use. Whereupon testimony was called for on the part of the prosecution, and the minutes of the trial referred to were principally relied upon. Brother Goode made a few statements, the substance of which was that Brother Daily had not informed him of his intention to leave Indianapolis at the time as set forth in his defense, and that from the state of the weather is was rather presumptive that he had left without much previous meditation. Brother S. C. Cooper then stated that he had been with Brother Daily, and he had iniormed him of his intention to leave the day before the principal occurrence alluded to in the testimony, and that he had in his presence taken leave of several friends. Testimony was then called for on the part of the defense, and a letter from Mr. Defrees, the husband of the lady alluded to, was presented, but objection being made it was not admitted as testimony, but Brother Daily was permitted to read it as a part of his defense and being much exhausted, the secretary, at his own request, read it as the introduction of his defense, and he followed with an address of some length; after which Brother Havens made a few remarks on the part of the prosecution, and Brother Daily was requested to retire. The following resolution was then presented by Brother A. Wood:

"Resolved, That the specifications and charges in 
the case of Brother Daily do not come under question 1st, but question 2d, in book of discipline, Sec. 19 .

\section{AARON WOOD, JOSEPH WHITE."}

Which after some deliberation was withdrawn by the mover. Brother Patrick then moved that in the opinion of this conference the charges are not sustained, which being seconded, on motion of Brother Eddy, conference adjourned and was closed with prayer by Brother Hargrave.

Wednesday morning, October 13, 1841. Conference met pursuant to adjournment and was opened with reading, singing and prayer by Brother Larrabee.

On motion of Brother Havens, Brothers Young, Hanneman and Drom were called to give testimony in reference to the character of the Hill family, and especially in reference to Margaret Hill, the principal witness of the prosecution. All of whom concurred in saying that their character was unexceptionable, which was confirmed by Brothers Wiley, Eddy and Goode. The motion made on yesterday by Brother Patrick was by him withdrawn, and he presented a resolution which being amended was passed in the following shape, viz.:

"Resolved, That both specifications under the charge against the accused are in the opinion of the conference sustained."

The following resolution was presented and passed:

"Resolved, That this conference having found Brother Daily guilty of unministerial and imprudent conduct in the specifications above mentioned, do therefore consider that he be admonished by the chair, and that his character pass.

S. C. COOPER,

E. R. AMES." 
The following resolutions were presented and passed:

Resolved, That in the action had in this conference in the investigation of a charge against Rev. William M. Daily and the decision, thereupon this conference does not impute to the family of Mr. Arthur Hill, of Indianapolis, any want of veracity, nor anything which can affect the reputation and character of said family.

W. H. GOODE,

E. R. AMES.

Resolved, That the secretary be directed to furnish Brother Hill a copy of the above resolution.

Brother Daily being called before the conference, Bishop Roberts in compliance with a preceding resolution delivered an affectionate and appropriate admonition to brother Daily, who in reply admitted his error and the propriety of the admonition, and promised in a solemn manner, hereafter to be more circumspect in his conduct, and to regard the present action of conference in kindness.

Brother Ames presented the report of the joint board of trustees and visitors of the Asbury University, which was filed among the papers of conference, after having been adopted, and its publication in the Advocate ordered.

Brother Cooper presented a statement of the funds raised for a library, and on motion the faculty of the institution were constituted a committee to receive and appropriate the funds which either have been collected or which may be collected for said purpose during the present year.

The stewards made their report by which it appears that the amount of claims are $\$ 32,182.20$, the amount of receipts, $\$ 20,771.10$, and the deficit, $\$ 12,209.10$. That they were enabled to report a dividend of thirty and one-fourth per cent., having received from fifth 
collections $\$ 247.91$, from conference collections, $\$ 73.00$, Book Concern, $\$ 700.00$, chartered fund, $\$ 69.00$; total, $\$ 1,089.91$, and the dividends were distributed according to their report, after it had been adopted by the conference, which report is filed among the papers of conference.

On motion of Brother Cooper the balance in the hands of the stewards, after paying for stationary, etc., was appropriated to Sister Chord. Brother Ackerman also desired his dividend to be given to Sister Chord, which was accordingly done.

On motion of Brother Wiley, conference adjourned to meet at two o'clock and was closed by prayer by Brother J. J. Cooper.

Wednesday afternoon, October 13, 1841. Conference met pursuant to adjournment and was opened with reading, singing and prayer by Brother Rutledge.

On motion of Brother Wiley the superintendent was requested to appoint Brother J. C. Cooper as agent for the university.

On motion of Brother Ames, P. J. Beswick was discontinued at his own request to pursue his studies.

Brother E. G. Wood moved the discontinuance of Brother Dayle at his own request.

On motion the conference proceeded to elect nine visitors of the university in accordance with the provision of the charter, whereupon, on counting the vote, A. Eddy, J. C. Smith, J. Havens, C. W. Ruter, A. Wiley, L. W. Berry, E. R. Ames, W. H. Goode and Aaron Wood were elected said visitors.

The following resolutions were severally presented and passed, viz.:

"Resolved that the thanks of this conference be tendered to the citizens of this town and its vicinity for the kind and equitable manner in which they have received and entertained the conference during its pres- 
ent sitting, and that the preacher officiating next Sabbath announce the same from the pulpit.

\section{ALLEN WILEY,}

\section{A. EDDY."}

Resolved that the thanks of this conference be tendered to Rev. Mr. Jewett and his congregation for the use of their church on last Sabbath.
A. WILEY,
A. EDDY."

Resolved that the secretary be requested to furnish the editors of the Wabash Courier and the Greencastle Visitor list of the appointments and request their publication.

A. WILEY,

A. EDDY."

The conference then proceeded to elect a place for next conference, and on motion of Brother Ames, it was resolved that a majority be required to select the place; whereupon Centerville, Madison, Jeffersonville, Lafayette and South Bend were named, and on the second ballot Centerville was selected as the place, and the bishop announced the time to be October 19, 1842 .

In reference to Act of the Legislature of this state at its last session, the following resolutions were presented and passed, viz: Resolved, that Samuel S. Cooper be, and is hereby appointed, an agent for "the conference of the Methodist Episcopal Church, of the state of Indiana," for the purpose of collecting, subscriptions made with the view to the building of a college edifice at the town of Greencastle, in this state.

Resolved, that all subscriptions belonging to this conference for this purpose, be placed in the hands of said agent.

The following resolutions were presented and passed: "Resolved, that viewing the missionary cause as of paramount importance and having much confidence in the success of fervent-believing prayer, we 
deem it expedient that there should be holden a missionary prayer meeting, and that we will endeavor to have such meetings established so far as practicable, in all the societies throughout our work, and that at such meetings we consider it advisable to lift collections in aid of the missionary cause. Second, That the first Monday evening in each month be set apart for the missionary prayer meeting in all our societies if convenient, and if not, some evening as soon thereafter as circumstances will permit. C. W. Ruter, R. S. Robinson."

"Resolved, that we recommend to the people of our respective charges to observe Friday, the 24 th of December next, as a day of fasting or abstinance, and to commence on that day in each society, where practicable, a four days' prayer meeting, and that such meetings be protracted to a greater length, where circumstances appear to justify such a course. C. W. Ruter, A. Eddy."

"Resolved, that the secretary be requested to furnish all papers of a general character, at his discretion, for publication in the Western Christian Advocate. A. Eddy, C. W. Ruter."

The committee on the Preachers' Aid Society report as follows: "The committee appointed to disburse the funds arising from the Preachers' Aid Society have had the subject under consideration and make the following report, viz: There are four hundred and fifteen dollars and twelve and a half cents on hand, the proceeds of the above fund, which we have appropriated as follows, viz:
To James Jones $\$ 25.00$
To Charles Bonner 65.00
To Miles Huffaker 35.00
To Wm. H. Smith 25.00
To James L. Thompson
To H. Vredenburgh. 95.00 


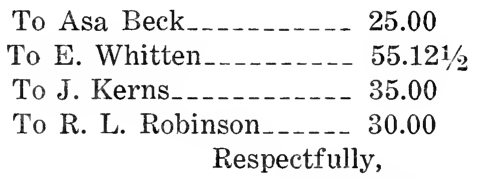

A. WILEY, Chairman.

Which report was adopted.

The committee on the American Bible Society, reported as follows, viz. "Resolved, First, That we highly approve the designs and operations of the American Bible Society, and that we learn with great pleasure its intention of affecting a resupply of the destitute in our state and country, and most cordially do we recommend it to the confidence, prayer and patronage of our people within the bounds of this conference.

"Resolved, Second, That we invite the accredited agents of the American Bible Society to visit our congregations and will co-operate with them in carrying out the objects of this society so far as our other ministerial duties will permit.

"Resolved, Third, That when such agents shall visit any of our congregations they shall be authorized to take collections for the purposes above specified if it should be deemed prudent.

"Resolved, Fourth, That each preacher in charge of the circuits and stations be requested to preach at least one sermon in the course of the year in each station, and at appropriate places in each circuit, on the claims of the American Bible Society, and the importance of Biblical knowledge."

The following resolutions were presented and adopted:

"Resolved, That we respectfully request the agents of our Western Book Concern to make arrangements to furnish as soon as practicable a more ample supply of books, adapted to the wants of our Sabbath schools.

$$
\begin{aligned}
& \text { C. W. RUTER, } \\
& \text { F. C. HOLLIDAY." }
\end{aligned}
$$


"Resolved, That when we adjourn, we adjourn to meet again this evening at $61 / 2$ o'clock to hear the address of the bishop and to receive our appointments."

Brother A. Wiley asked a superannuated relation for Brother William Knowles, which was granted.

The report of the book committee was read and adopted and filed among conference papers.

On motion conference was closed with benediction by the bishop.

Wednesday evening, October 13, 1841. Conference met pursuant to adjournment and was opened with reading, singing and prayer by Brother Havens.

On motion of Brother Ruter, J. M. Hofer was elected to Deacons Orders, he being a missionary among the Germans.

And conierence was closed with singing by Bishop Roberts and prayer by Brother Swormstedt, after which an impressive address was delivered by the bishop, and the appointments were read and the preachers dismissed with the benediction.

Attest:

R. R. ROBERTS.

M. SIMPSON, Secretary.

APPOINTMENTS FOR 1841.

Madison District.

C. W. Ruter, Presiding Elder.

Madison-Allen Wiley.

Paris-Seth Smith.

Vernon-Lemuel M. Reeves.

Canaan-Hayden Hays, George W. Baker.

Vevay-James Crawford, one to be supplied.

Rising Sun-Amos Bussey, George W. Stafford.

Lawrenceburg Station-Samuel T. Gillett.

Manchester-Richard Hargrave, Thomas A. Goodwin.

Wilmington-James Jones, D. M'Intyre.

Lawrenceburg German Mission-Jno. Kisling. 


\section{Charlestown District.}

E. G. Wood, presiding Elder.

New Albany-William V. Daniel, W. Malick.

Corydon-Thomas Ray, Charles Mapes.

Greenville-Emmons Rutledge.

Salem-Charles Bonner, Jacob Whitman.

Charlestown-C. B. Jones, M. Benton.

Lexington-G. C. Beeks, A. Wilkerson.

Jeffersonville-Fernandes C. Holliday.

Rome-Edward Oldham.

New Albany German Mission-M. J. Hofer.

\section{Vincennes District.}

H. S. Talbott, Presiding Elder.

Evansville-John Kearns.

Mt. Vernon-Anthony Robinson, S. Ravenscroft.

Princeton-Isaac M'Elroy, J. A. Decker, sup.

Boonville-William Bratton.

Rockport, Daniel S. Elder.

Vincennes-Elijah Whitten.

Washington-John Talbott.

Carlisle-John Daniel, James Corwine.

Lebanon-Eli C. Jones.

Bruceville-Alfred B. Nesbit.

\section{Greencastle District.}

George M. Beswick, Presiding Elder.

Greencastle-Isaac Owen.

Putnamville-Isaac Crawford.

Russellville-Thomas Bartlett, W. Dorsey.

Rockville-Cornelius Swank.

Terre Haute, embracing Mt. Pleasant and Otter Creek meeting-houses-John S. Bayless.

Prairietown-Elam Jenung.

Roseville-Zachariah Games.

Newport-Ezra L. Kemp. 
Danville-Joseph Marsee.

Indiana Asbury University-Matthew Simpson, President; Cyrus Nutt, Professor of Languages; William C. Larrabee, Professor of Mathematics and Natural Science; S. C. Cooper, Agent.

\section{Crawfordsville District.}

John C. Smith, Presiding Elder.

Crawfordsville-Samuel Brenton.

Ladoga-Allen D. Beasley, R. H. Calvert.

Frankfort-William Wilson, Samuel Reed.

Covington-J. B. Mershon, R. C. Rowley.

Newtown-Thomas J. Brown, J. White.

Augusta-Jonas L. Belotte.

Lebanon-John Edwards.

Alamo-Daniel Demott.

Peirysville-Joseph S. Barwick.

\section{Lajayette District.}

Charles M. Holliday, Presiding Elder.

Lafayette-Amasa Johnson.

Dayton-Jacob Colclazer.

Delphi-William M. Fraley, J. H. Newland.

Logansport_James Black.

Rochester-Ancil Beach.

Winnemeck Mission-Everitus Doud.

Jasper Mission-H. N. Barnes.

Monticello-Enoch Wood, John Ritchie, sup.

Williamsport-J. J. Cooper, W. L. Huffman.

\section{South Bend District.}

A. Wood, Presiding Elder.

South Bend-George M. Boyd, W. Griffith.

Mishawaka-Hawley B. Beers.

Goshen-E. Holstock, W. F. Wheeler.

Lagrange-J. C. Medsker. 
Haw Patch-C. W. Miller.

Laporte-Wade Posey, George W. Ames.

Valparaiso-Isaac M. Stagg.

Yellow River Mission-William J. Forbes.

Fort Wayne District.

B. Westlake, Presiding Elder.

Fort Wayne-F. A. Conwell.

Decatur-Jesse Sparks.

Auburn-Samuel K. Young.

Steuben-E. S. Blue.

Eel River Mission-Samuel Smith.

Peru-John F. Truslow.

Warsaw-Orange V. Lemon.

Upper Wabash Mission-Allen Skillman.

Fort Wayne German Mission-To be supplied.

Winchester District.

Robert Burns, Presiding Elder.

Winchester-John H. Hull.

Portland-Joseph Ockerman.

Munceytown-John L. Smith.

Granville-B. H. Bradbury.

Marion-Hezekiah Smith, B. Webster.

Andersontown-John W. Bradshaw.

Pendleton-John S. Donaldson.

Bluffton-H. K. Bradley.

Newcastle_John H. Bruce, S. C. Swayze.

Connersville District.

A. Eddy, Presiding Elder.

Connersville-John Kiger, Jacob Bruner.

Centerville-Miltiades Miller, C. B. Davidson.

Richmond-Richard S. Robinson.

Liberty-Joseph Tarkington, George Havens.

Brookville-William W. Hibben, J. Hill, L. Havens. 
Greensburg-John W. Sullivan.

Millroy-Lewis Hurlburt, N. S. Worden.

Versailles-Francis H. Carey.

Bloomington District.

John Miller, Presiding Elder.

Bloomington-Jacob M. Stallard.

Springville-Draper Chipman.

Bedford-Peter R. Guthrie.

Brownstown-William Maginnis.

Columbus-Williamson Terrel, T. F. Spillman.

Spencer-E. Patrick, J. B. Demott.

Paoli-Philip May, M. Mahen.

Brown Mission-Lealdes Forbes.

Richland Mission-James R. Williams.

Leesville-George W. Walker.

\section{Indianapolis District.}

James Havens, Presiding Elder.

Indianapolis-William $\mathrm{H}$. Goode, one to be supplied.

Noblesville_Jacob Miller, J. Myers.

Mooresville-John B. Birt, David Crawford.

Franklin-John L. Kelly, A. Paris.

Shelbyville-H. S. Dane, James D. Templin.

Rushville-Lucian W. Berry, J. W. Mellender.

Knightstown-George W. Bowers, D. F. Stright.

Greenfield-William C. Smith, J. V. R. Miller.

Pipe Creek Mission-Miles Huffaker.

E. R. Ames, Corresponding Secretary of the Missionary Society of the Methodist Episcopal Church.

JOURNAL of the 11th Annual Session of the Indiana Conference Held in the Methodist Church in Centerville, October 19th, 1842.

Wednesday morning, 9 o'clock. Conference met pursuant to appointment and was opened by Bishop 
Morris by reading part of third chapter of Colossians and by singing and prayer.

The list was then called by M. Simpson, the secretary of last conference, and the following members were found to be present, viz.: C. W. Ruter, E. G. Wood, H. S. Talbott, G. M. Beswick, J. C. Smith, C. M. Holliday, Aaron Wood, Burris Westlake, Robert Burns, Augustus Eddy, John Miller, James Havens, Allen Wiley, Amos Bussey, S. T. Gillet, William V. Daniel, C. B. Jones, G. C. Beeks, F. C. Holliday, Anthony Robinson, Isaac McElroy, Elijah Whitten, John Daniel, Isaac Owen, Isaac Crawford, Thomas Bartlett, Cornelius Swank, John T. Kelly, G. W. Stafford, John H. Hill, Peter R. Guthrie, James R. Williams, J. V. R. Miller, J. S. Bayless, L. Games, E. L. Kemp, Joseph Marsee, M. Simpson, W. C. Larrabee S. C. Cooper. Allen D. Beasley, J. B. Mershon, Thomas J. Brown, J. L. Belotte, John Edwards, Daniel DeMotte, Amasa Johnson, Ancil Beach, Enoch Wood, Joriah J. Cooper, G. M. Boyd, Warren Griffeth H. B. Beers, Wade Posey, William J. Forbes, John Bruce, John Krigger, Miltiades Miller, R. L. Robinson, Joseph Tarkington, Rosetta Rowley, W. L. Huffman, Landy Havens, G. W. Ames, Draper Chipman, J. F. Truslow, W. W. Hibben, John W. Sullivan, Lewis Harbutt, F. H. Cary, William McGinnis, E. Patrick, Philip May, G. W. Walker, William H. Goode, Jacob Miller, J. Myers, L. W. Berry, George W. Bowers, D. F. Stright, Miles Huffaker, J. C. Harbin, J. Scott, David Stiver, W. M. Daily, J. A. Brouse, H. Vredenburgh, Silas Rawson, Bardon H. Bradbury, Seth Smith, Cyrus Nutt, James Hill, Joseph S. Barwick, Lealdes Forbes, Samuel Reed, William F. Wheeler, James Crawford, George Havens.

The conference then proceeded to elect a secretary by ballot and upon counting the votes M. Simpson, having received a majority of all the votes was declared duly elected. 
On motion of Brother A. Wood, Brothers Eddy, Miltiades Miller and R. S. Robinson were appointed a committee to select preachers during conference, and superintend the religious services, and on motion of Brother Eddy, Brother Tarkington was added to said committee.

On motion of Brother Wiley the hour of assembling was fixed at 8 o'clock in the morning and adjournment at 2 .

The conference then proceeded to the election of three stewards, by ballot, and upon the votes being received, on motion of Brother Ruter, the election was decided by plurality. Thereupon Brother S. C. Cooper, C. Nutt and W. H. Goode were duly elected. But on motion, Brother Goode was excused on account of engagements with the Missionary Society, and Brother J. Scott, being the next highest, was appointed in his place.

On motion of Brother Wiley, the conference proceeded to elect three stewards to disburse the funds received from the Preachers' Aid Society, in accordance with the provisions of the constitution of said society, and on motion, the choice was determined by plurality. Whereupon Brothers Wiley, C. W. Ruter and James Havens were declared duly elected.

On motion of Brother Eddy, the conference resolved to have a committee of three upon necessitous cases, and the appointment was left with the chair.

On motion of Brother Ruter, a committee of three to prepare memoirs of the dead was ordered, and the appointment was left with the chair.

On motion of Brother Eddy, the central and corner seats were reserved for the use of members of the conference and aisles adjoining the seats were constituted the bar.

On motion of Brother Ruter, the by-laws adopted at the first session of this conference, including the 
amendment as to closed doors, were adopted as the bylaws of this conference.

On motion of Brother Ruter, a committee of three was ordered upon Book and Periodical accuunts, and the appointment was left with the chair.

On motion of Brother S. C. Cooper, a committee was ordered to take into consideration the propriety of making arrangements for the division of this conference at the ensuing General Conference, and report to this conference at its present session, and upon motion of Brother Eddy, the committee was to be composed of one from each district; whereupon Brother Allen Wiley, W. V. Daniels, John Kearns, S. C. Cooper, T. J. Brown, Amasa Johnson, George W. Ames, F. A. Conwell, J. H. Bruce, R. S. Robinson, L. W. Berry and Philip May were appointed.

Brother Swormstedt was permitted to address the conference a few minutes upon the subject of the Book Concern.

On motion of Brother H. S. Talbott, a committee was ordered to estimate the table expenses of Bishop Roberts, and Brothers H. S. Talbott, A. Wood and John Miller were appointed said committee.

The second question on the minutes was then taken up, viz: "Who remain on trial?" and the characters of Charles Mapes, David Crawford, James D. Templin, Alfred B. Nesbit, James Corwin, Jesse Sparks, Absalom Paris, Williamson Terril, James H. Newland, Jacob Bruner, Hezekiah Smith, John W. Bradshaw, Henry H. Badley, S. C. Swayze, Milton Mohen, N. H. Barnes, Orange V. Lemon, Elijah S. Blue, J. C. Medsker and Jacob Whiteman were severally examined and passed, and they were continued on trial-the character of James Black was examined and passed, and he was discontinued at his own request on account of ill health.

The fourth question of the minutes was taken up, 
viz: "Who are the deacons?" and the characters of Peter R. Guthrie, Edward Oldham, James R. Williams, John V. R. Miller, Rosetter Rowley, Stephen Ravenscroft, John L. Donaldson, Joseph Ockerman, Enoch Holdstock, William Wilson, Landy Havens, George W. Ames, Draper Chipman, Lealdes Forbes, Wesley Dorsey and Samuel Reed were examined and passed.

The name of George W. Baker was called and it was announced by his Presiding Elder Brother Ruter, that he had died of pulmonary affection on the 9 th of last April, in great peace.

On motion of Brother Wiley, it was resolved that when conference adjourned, it adjourned to meet at 2 o'clock in the afternoon, to continue the examination of character.

The hour of adjournment having arrived, after some notices had been given, conference was closed with prayer by Brother Sullivan.

Wednesday afternoon, 2 o'clock, October 19th, 1842. Conference met pursuant to adjournment and was opened by reading, singing and prayer, by Brother Marsee.

The roll was then called and on motion of Brother Wiley, the calling of the roll was hereafter dispensed with. The Journals were read and approved, and a communication was read from the book agent at New York, requesting a list of postoffices in the bounds of this conference. And on motion of Brother Tarkington, a committee was ordered for said purpose.

The fourth question of the minutes was resumed, and the name of William F. Wheeler being called, it was resolved, that he should be reproved and admonished by the chair, and that his character pass, which was accordingly done.

The characters of Walter L. Huffman and George Havens were examined and passed.

The fifth question of the minutes was taken up, viz: 
"Who have been elected and ordained elders this year?" and the characters of John F. Truslow, Bardon H. Bradbury, Seth Smith, Cyrus Nutt, Francis A. Conwell, James Hill, Joseph S. Barwick, John Talbott, John L. Kelly, George W. Stafford, John H. Hall and James Crawford were severally examined and passed, and they were elected to elders orders.

The conference proceeded to the examination of the characters of elders, and the characters of Calvin W. Ruter, Allen Wiley, Samuel M. Reeves, Amos Bussy, Richard Hargraves, James Jones, Enoch G. Wood, William V. Daniels, Thomas Ray, Emmons Rutledge, Constant B. Jones, G. C. Beeks and F. C. Holliday were examined and passed.

On motion of Brother Eddy, conference adjourned and was closed with prayer by Brother Havens.

Tuesday morning, 8 o'clock, October 20th, 1842. Conference met pursuant to adjournment, and was opened with reading, singing and prayer by Brother Wiley, and the minutes were read and approved. The Bishop announced the following committees:

On necessitous cases-Brothers Joseph Marset, William V. Daniels, Ancil Beach.

On Book and Periodical accounts-Ebenezer Patrick, William W. Hibben, Samuel T. Gillet.

On Memoirs-C. W. Ruter, Richard Hargrave.

On Postoffices-Joseph Tarkington, John A. Brouse.

The Bishop presented a communication from the Book Agents at New York, giving an exhibit of the state of the Book Concern, which was read by the secretary, and filed among the papers of the conference.

The stewards then called for claims and receipts.

At the suggestion of the Bishop, conference voted to draw upon the Book Concern for eight hundred dollars, and Brother Goode reported four hundred and thirty dollars from the Preachers' Aid Society.

The candidates for admission into full connection 
were then called forward, and the questions authorized by the discipline were propounded by the Bishop, and some remaris made in an impressive manner, after the questions had been satisfactorily answered, the committee of examination made their report, and the character's of Charles W. Miller, Daniel McIntire, John W. Mellander, Robert H. Calvert, Britton Webster, Ailen Skilman, Charles B. Davidson, John B. DeMotte, Asbury Wilkinson, Thomas A. Goodwin, William C. Smith, Eil C. Jones, Hayden Hays and Washington Masick were severally examined, and they were admitted into full connection and elected to deacons orders, and Brother Malick, through his elder, asked and obtained a location. The characters of Elam Genung, John L. Smith and John Kisling were examined and they were admitted into full connection, having been previously ordained.

The character of Daniel S. Elder and Isaac M. Stagg were examined and passed, and not being present, they were continued on trial.

On motion of Brother Wiley, it was resolved that when conference adjourned, it adjourned to meet at 2 o'clock.

The hour of adjournment having arrived, after notices had been given, conference was closed with prayer by Brother A. Wood.

Thursday afternoon, October 20th, 1842. Conference met pursuant to adjournment, and was opened with reading, singing and prayer by Brother S. C. Cooper, and the minutes were read and approved.

The committee on Bishop Roberts' table expenses reported by Brother $\mathrm{H}$. S. Talbott, their chairman, that they had agreed upon the sum of four hundred dollars, as the amount necessary to meet the above expenses for the current year.

The characters of J. M. Hofer, Morris Brenton, Samuel Smith and Samuel K. Young were examined 
and passed, and they were discontinued at their own request.

The character of Nathan S. Worden and William Bratton, were examined and passed and they were continued on trial.

The Bishop then invited those admitted into full connection to take their seats, and share in the deliberations of the conference.

And on motion by Brother Wood, conference adjourned.

Friday morning, 8 o'clock, October 21st, 1842. Conference met pursuant to adjournment and was opened with reading, singing and prayer, by Brother James B. Finley of the Ohio conference, and the minutes were read and approved.

Brother Swormstedt, one of the Western book agents, read the exhibit of the Western Book Concern, which was filed among the papers of the conference, and Brother Swormstedt made an address on the subject to the conference.

Some letters from Arkansas were presented by the Bishop, and read by the secretary, after which the Bishop made an address, requesting volunteers for Arkansas.

The examination of the characters of elders was resumed, and the characters of Samuel T. Gillet, Charles Bonner, H. S. Talbott, John Kearns, Anthony Robinson, Isaac McElroy, Elijah Whitten, John Daniel, George M. Beswick, Isaac Owen, Isaac Crławfiord, Thomas Bartlett, Cornelius Swank, John S. Bayless, Zachariah Games, Ezra L. Kemp, Joseph Marsee, M. Simpson, William C. Larrabee, S. C. Cooper, John C. Smith, Samuel Brenton, Allen D. Beasly, Amasa Johnson, Jacob Colclares, Ancil Beach, Enoch Wood were examined and passed.

Characters of John A. Decker, John R. Richey were 
examined and passed and they were placed in a supernumerary relation.

Character of Thomas J. Brown was examined and passed, and at his request, he was placed in a superannuated relation.

The name of J. L. Belotte being called and some explanations being requested, a committee consisting of Allen Wiley, James L. Thompson and Thomas J. Brown were appointed to examine the case.

On motion of Brother Ruter it was resolved that when conference adjourn it adjourned to meet at 2 o'clock.

On motion of Brother A. Wood, conference adjourned and was closed with prayer by Brother Musgrove.

Friday afternoon, 2 o'clock, October 21st, 1842. Conference met pursuant to adjournment and was opened by reading, singing and prayer by Brother DeMotte, and the minutes were read and approved.

Brother James B. Finley gave some remarks concerning the state of the Book Concern and some infor'. mattion as to salaries of agents, editors, etc.

The character of Eventus Doud was examined and passed, his name having been omitted in the list of deacons.

The characters of J. J. Cooper, A. Wood, G. M. Boyd, W. Griffith, Hawley B. Beers, Wade Posey, Wm. J. Forbes, Burris Westlake, Robert Burns, John H. Bruce, A. Eddy, John Kiger, Miltiades Miller, R. S. Robinson, Joseph Tarkington, William W. Hibben, John W. Sullivan, Lewis Hurbut, Francis H. Cary, John Miller, Jacob M. Stallard, William McGinnis, T. F. Spillman, E. Patrick, Philip May, George W. Walker, James Havens, Wm. H. Goode, Jacob Miller, J. Myers, John B. Birt, Lucien W. Berry, George W. Bowers, D. F. Stright, Miles Huffaker and E. R. Ames were examined and passed. 
On motion of Brother Holliday, a committee was ordered upon periodicals and the chair announced $\mathbf{M}$. Simpson, F. C. Holliday and W. M. Dailey as said committee.

The characters of William Knowles, J. C. Harbin and James L. Thompson were examined and passed and they were continued in a superannuated relation. And the character of Henry S. Dane was passed and he was placed in a superannuated relation.

The character of Silas Bawson and James Scott were examined and passed and their relation was changed from a superannuated to an effective one.

Tize character of David Stiver was examined and passed, and a location was granted him at his own request.

On motion of Brother Eddy it was resolved that the anniversary of the Preachers' Aid Society take place on Monday next at 2 o'clock p. $\mathrm{m}$.

On motion, conference adjourned and was closed with the benediction.

Saturday morning, 8 o'clock, October 22nd, 1842. Conference met pursuant to adjournment and was opened with reading, singing and prayer by Brother Beswick, and the Journals were read and approved.

The following resolutions were presented, viz: "Resolved, that a committee of three to be denominated a commirtee of finance, whose duty it shall be to devise and present some plan for more efficiently raising the several allowances of the preachers of this conference. and report as soon as practicable. S. W. Ruter, E. G. Wood." Which committee was ordered and the chair appointed C. W. Ruter, E. G. Wood and Joseph Marsee, and on motion of Brother Cooper, Brother Hibben was added to said committee.

Resolved, that a committee of three be appointed to examine Bishop Heddings' Discourse on Discipline, and report on the expediency of following in our adminis- 
tration the course there recommended. C. W. Ruter, F. C. Holliday." Which committee was ordered and the chair appointed Allen Wiley, A. Eddy and F. C. Holliday as said committee.

The conference resumed the examination of elders, and the characters of Benjamin P. Grifith, William Shanks, John A. Brouse, H. Vredenburgh, Asa Beck and William H. Smith were examined and passed, and they were continued in a superannuated relation.

The name of William M. Daily having been called, on motion, his case was laid over to allow brethern the opportunity of conversing with him.

The name of William M. Fraley having been laid over, his character was examined and passed.

The recommendations of local preachers to deacons orders, were now taken up, and the following brethern were elected to deacons orders, viz: Parmenius J. Rosecronts, from the Madison district; John W. Willey and Pleasant E. Boyse, from the Charlestown district; Richard J. Tindall, from the Vincennes district; Nathaniel Jones, from the Greencastle district; Hugh Wells, from the Crawfordsville district; James Redding, from the South Bend district; George C. Whiteman, George Guild, William Curtis and Ezra Lank, Jr., from the Winchester district; David Alley and Alvah Stone, from the Connersville district; James King, from the Bloomington district, and Isaac Martindale, John Robe and David Crawford, from the Indianapolis district; also William Faulkner, recommended from the Greencastle district, and Charles McCarty, recommended from the Winchester district, were not elected.

The following persons, duly recommended from these several districts, and having certified or testified their belief in the doctrines of our Church, and their adherenc to our discipline, were elected to elders orders, viz: Joseph Wheeler, from the Vincennes district; William Campbell, from the Crawfordsville dis- 
trict; Townsend Truslow, from the Winchester district; James Taylor and Presley S. Silvoy, from the Connersville district, and Thomas W. Sargent, from the Indianapolis district.

The numbers were then read in the conference and there appeared as follows:

The time of adjournment having arrived, conference was closed with prayer by Brother Patrick.

Monday morning, October 24th, 1842. Conference met pursuant to adjournment and was opened with reading, singing and prayer by Brother Burns, and the Journals were read and approved.

Bishop Morris then presented the following list of brethern by him ordained on yesterday (the 23) as deacons and elders, viz:

Deacons: Charles W. Miller, Daniel McIntyre, John W. Mellander, Robert H. Colvert, Brinton Webster, Allen Skillman, Charles B. Davidson, John B. DeMotte, Asbury Wilkenson, Thomas A. Goodwin, William C. Smith, Eli C. Jones, Hayden Hays, Washington Maylick, Pleasant E. Royse, Richard J. Lyndall, David Crawford, David Simmons, Stephen Norman, Edward White, George C. Whiteman, David Alley, George Guild, Ezra Lank, Jr., Elijah Harbour, Alvah Stone and Charles Clemmons (colored) 27.

Elders: John F. Truslow, Barden H. Bradbury, Seth Smith, Cyrus Nutt, Francis A. Conwell, James Hill, Joseph S. Boswick, John L. Kelly, George W. Stafford, John H. Hull, James Crawford, Silas Rawson, Townsend Truslow, James Taylor and Presley S. Silvey, 15. Total, 42.

Brother Ruter, chairman of the financial committee reported, which report was adopted and filed among the conference reports.

Brother Swormstedt addressed the conference on the subject of the Book Concern, and reported sever- 


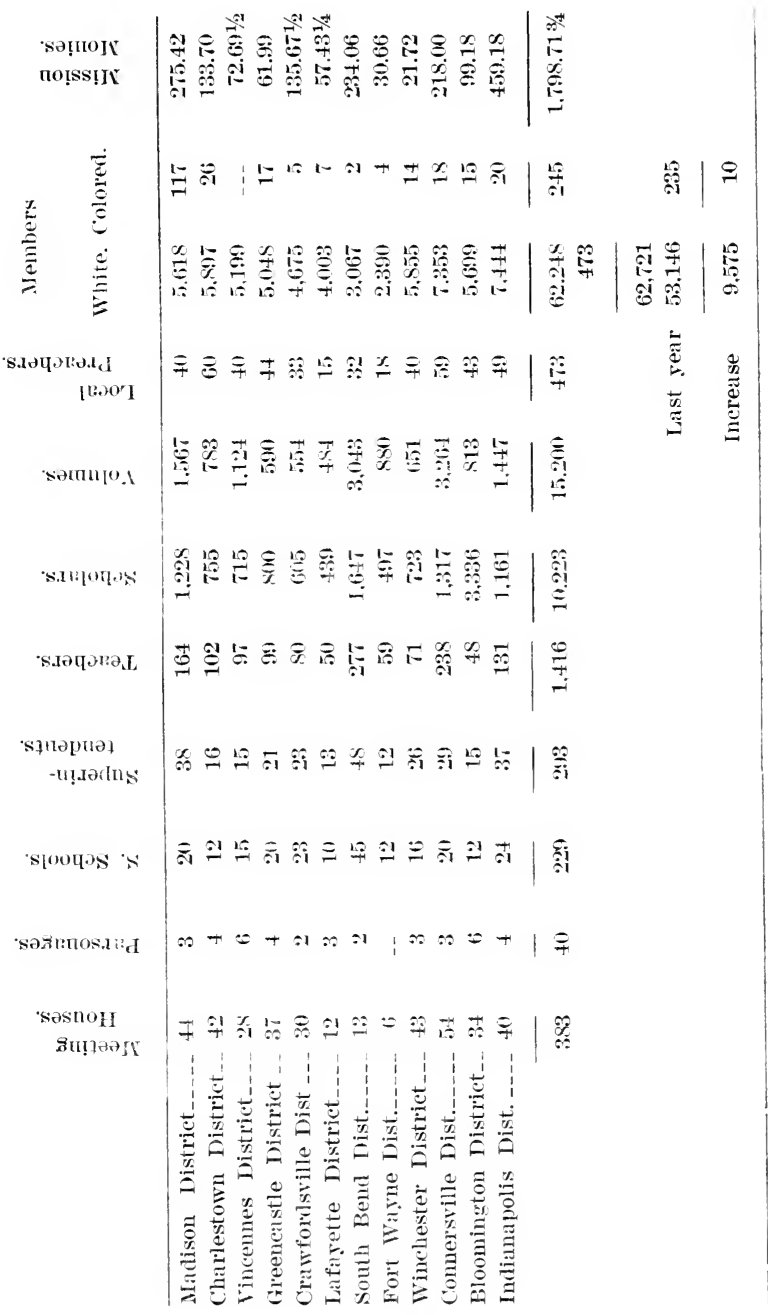


ally, cases for conference action, which were disposed of as follows, viz:

The claims on Robert Johnson and S. H. Rogers were advised to be considered by the agents as lost debts.

The claims on Jonas L. Belotte and Amasa Johnson were referred to a committee consisting of Brothers Gillet, Games and Scott.

The claims on Dr. Oglesby were referred to the preacher in Third street charge, Madison, and the claims on J. Williams were referred to the preacher on Martinsville circuit; Brother Balue referred to preacher on Ft. Wayne; Brother Beharrais to preacher at New Albany; T. J. Doyles' account referred to preacher on Charlestown circuit, and the secretary was directed to furnish Brother Swormstedt a copy of these resolutions.

A collection was now taken up to defray the expenses of Bishop Roberts' portrait, and on motion of Brother Wiley, the portrait was ordered to be placed in the college chapel immediately behind the rostrum, and covered with a suitable cloth, and Brother S. C. Cooper was appointed an agent to carry the resolution into effect.

The chair appointed M. Simpson, J. S. Bayless and E. Patrick as a committee to write a pastoral address as alluded to in the financial plan. The conference ordered the printing of one thousand copies of the financial plan, and F. C. Holliday and Thomas A. Goodwin were appointed said committee.

On motion of Brother Goode, William V. Daniel was appointed on the committee on periodicals in place of M. Simpson.

Brother William M. Daily's name being called and a charge having been preferred against him, on motion of Brother S. C. Cooper, the matter was referred to a 
committee, and Brother Thompson, James Jones, Daniel DeMotte, William V. Daniel and Joseph Marsee.

The hour of adjournment having arrived, conference was closed with prayer by Brother Scott.

Tuesday morning, October 25th, 1842. Conference met pursuant to adjournment, and was opened with reading, singing and prayer by Brother Brouse; and the minutes were read and approved.

A communication was received from Henry Brenton, praying for redress, which was read and laid upon the table, conference declining any action in the premises.

Brothers Sebon and James, agents of the Bible cause, were introduced to conference, and on suggestion of Brother James, a committee was appointed consisting of Brothers Wiley, Brown and Ames, to confer upon the Bible cause and report to this conference.

The committee on the case of Brother William M. Daily reported that: "After having the persons referied to, consisting of Brothers Cooper, Hargrave, Holliday, Hibben, Hays, Cary, Stiver, Goodwin and John Daniel, are of opinion that no ground of impeachment whatever exists in reference to the case of Brother William M. Daily, and therefore unanimously recommend that his character be passed without censure by this conference. James L. Thompson, President; J. Marsee, J. Jones, D. DeMott, William V. Daniel, Secretary. Which report was adopted, and his relation was changed from superannuated to efiective.

The committee on Brother Belotte's case reported as follows: That after hearing the testimony of several brethern, they have no evidence to convince them that Brother Belotte has in any way wronged the interpreter employed by him.

As it regards some other matters, the committee find themselves in an embarassing and painful condition. If there be no mistake in the understanding and 
memories of Brothers Cooper and Beswick, the committee is led to the conclusion that Brother Belotte did obtain an additional appropriation of missionary funds at the Indianapolis conference by false representations, in stating that he had paid the wages and expenses of the interpreter out of his own salary. All of which is respectfully submitted.

ALLEN WILEY, Chairman Committee.

Centerville, October 22nd, 1842.

J. L. Thompson, T. J. Brown.

Testimony was then produced, and Brother Belotte made his defence. (See minutes kept among conference papers.) After Brother Belotte retired, the report of the committee was accepted and filed among the conference papers. After some discussion, the following motion was made by Brother Johnson: "Resolved, that in the opinion of this conference the missionary committee were deceived in making the additional appropriation in Brother Belotte's case, but that he did not willfully or intentionally deceive them," which was adopted. Whereupon, on motion of Brother Holliday, it was resolved, that Brother Belotte be required to refund the sum of $\$ 42.50$ to the Missionary Society, that being the sum collected by him while on the Miami Mission. And on motion, his character passed, and he was located at his own request.

On motion, resolved, that in the decision on Brother Belotte's case, this conference did not in the least degree, discredit the testimony of Brothers Cooper or Beswick.

On motion of Brother Miller, the decision of this conference in the case of Brother Griffith was reconsidered, and his relation was changed from superannuated to effective.

On motion of Brother Havens, the case of Brother 
Scott was reconsidered and he was placed on a supernumerary relation.

On motion of Brother Burns, Brother Ockerman obtained a location at his own request.

The committee on the Bible reported, and after an eloquent and impressive address by Brother Janes, their report was adopted and filed among the papers.

On motion of Brother Ruter, it was resolved that when conference adjourn, it will adjourn to meet at half past one o'clock to take up the first question of the minutes.

On motion, resolved, that the secretary furnish a copy of the resolution upon the Bible cause to the corresponding secretary of the Bible Society at New York.

The time having arrived, conference adjourned.

Tuesday afternoon, October 25th, 1842. Conference met pursuant to adjournment, and was opened with reading and prayer by Brother Kisling, and the minutes were read and approved.

The first question of the minutes was taken up, and the following persons were properly recommended and admitted, viz:

Hozier J. Durbin from the Madison district.

Pleasant E. Boyse from the Charlestown district. Elijah Lilleston from the Vincennes district.

Philip J. Beswick from the Greencastle district.

Jacob Cozad from the Lafayette district.

Nelson Green from the South Bend district.

John P. Jones from the Fort Wayne district.

Arthur Badley from the Winchester district.

John P. Lansey from the Connersville district.

Isaac J. Crouch from the Indianapolis district.

John S. Winchester from the Madison district.

John $\mathrm{H}$. Clippinger from the Vincennes district.

Henry C. Benson from the Greencastle district.

William Anderson from the Winchester district. 
Samuel P. Crawford from the Connersville district. Thomas M. Eddy from the Connersille district. William G. Stonex from the Madison district. John P. Parrott from the Vincennes district. Oliver H. P. Ash from the Greencastle district. F. F. Sheldon from the Indianapolis district. Elisha W. Cadwell from the Madison district.

Greenlee H. McLaughlin from the Greencastle district.

James Webb from the Connersville district.

Thomas C. Crawford from the Greencastle district. Samuel B. F. Crain from the Connersville district. William Shreck from the Connersville district.

John Robinson from the Lafayette district and Samuel Hicks from the Madison district were not admitted. J. F. Robe, an applicant for readmission, was not received.

On motion of Brother Ruter, the presiding elder has leave to employ Brother Hicks if necessary.

On motion of Brother S. C. Cooper, the memorial of $\mathrm{H}$. Brenton was placed in the hands of the elders of Indianapolis district, to be returned to him with the reasons why it could not be entertained.

On motion, conference adjourned and was ciosed with prayer by Brother Griffith.

Wednesday morning, October 26th, 1842. Conference met pursuant to adjournment, and was opened with reading, singing and prayer by Brother Spillman; and the minutes were read and approved.

The Bishop then announced the following committee of examination for the following year, viz:

On the Bible-Allen Wiley.

Wesley's Sermons-James Havens.

Fletcher's Appeal-James Jones.

Discipline-C. W. Ruter.

Watson's Life of Wesley-Aaron Wood. 
The Doctrinal part of Watson's Institutes-A. Eddy.

Ruter's Church History-M. Simpson.

English Grammar and Composition-E. Patrick.

Geography-C. Nutt.

The stewards then made their report, by which it appears that the whole amount of claims are $\$ 37,-$ 267.36. The whole amount of receipts $\$ 22,362.58$ and the deficit $\$ 14,904.78$. That there had been raised to meet the deficiency as follows: Fifth collection, $\$ 202.51$; Book Concern, $\$ 800$; Chartered Fund, $\$ 61$; Total, $\$ 1,063.51$. And the dividends were distributed according to their report, after it had been adopted by the conference.

Which report is filed among the papers of conference. On motion, the balance in the hands of the stewards, after deducting incidental expenses, be appropriated to meet the printing of the financial plan. On motion, Brother S. C. Cooper was appointed to correspond with Sister Barnes and endeavor to procure the relinquishment of the claim of her child in favor of the debt due the Book Concern.

The following resolutions were presented and adopted, viz:

"Resolved, that the members of this conference and the preachers on trial be required to procure from the recording stewards of their circuits and stations a certificate of their amount of quarterage and receipts and hand it to the stewards of conference on first day of session and that the stewards be requested to make out their report from said certificates.

"Resolved that the presiding elder be required to see that the above resolution is carried into effect in their districts respectfully. S. C. Cooper, C. Nutt."

Joseph F. Randolph, recommended from Greenville circuit, North Ohio conference, was admitted into traveling connection. 
The committee on book claims reported as follows: "Resolved, that the claim of the Book Concern against Brother J. L. Belotte be placed in the hands of the preacher in charge, within whose bounds he may reside, and that he immediately secure the claim by mortgage or otherwise, and that Brother Belotte be allowed until the 30th of April, 1843, to pay one half, and until the next annual conference to pay the residue of said claim. Which was adopted.

Resolved that the account of Brother A. Johnson be placed in the hands of his presiding elder, and that he be expected to pay one half of the claim against him by the 31st of January, 1843, and the residue one year from that time, and in event of failure, to pay the first instalment the elder have the claim secured by mortgage or otherwise, which report was adopted.

The following report was presented and adopted, viz: The committee to whom was referred the discourse of Bishop Hedding on the administration of discipline, have had the same under consideration, and report that although they have some small objections to some parts of it, yet as a whole, they regard it as a safe directory in the administration of the discipline, and would recommend it to the conference for that purpose.

The report of the visitors of the university was read and adopted, and filed among the conference papers. And conference proceeded to elect nine visitors for the ensuing year. And on motion of Brother J. C. Smith, a plurality should determine the election. And after the vote was taken, a committee (of three) consisting of C. Nutt were appointed to count the votes while the conference proceeded to business. On motion, the Bishop was requested to promote Brother S. C. Cooper, an agent of the university, for the ensuing year. On motion, Mr. John M. Allison of Greencastle, was elected a trustee in the university in conformity 
with the provisions of the charter. On motion of Brothers Eddy and Ruter it was resolved by this conference, that we use our best endeavors in our different fields of labor to increase the number of suitable students in the Indiana Asbury University.

The report of the mission committee was adopted and filed among the papers of conference, and on motion of Brother Wood, W. H. Goode was appointed on said committee in the place of Brother Brown.

On motion, conference proceeded to fix by nomination, the place of holding conference next year, and New Albany, Madison, Indianapolis, Crawfordsville and Charlestown were nominated, and Crawfordsville was selected, and the Bishop announced October 18th, 1843 , as the time of said conference.

On motion of Brothers Bayless and Holliday, it was resolved, that a committee be appointed to inquire whether any of the ministers who have officiated in either of the churches during the present session of our conference, have indulged in bitter uncharitable and unchristian denunciatitons of the particular tenets of sister evangelical churches." And the chair appointed J. S. Bayless, F. C. Holliday and J. Marsee.

The stewards presented an additional report, which was adopted.

The following resolutions were offered and adopted, viz: "Resolved, that Friday, the 30th of December" next, be set apart as a day of fasting or abstinence and prayer, within the bounds of this conference, and that we recommend to the people of our respective charges to commence on that day a four days' meeting, and that such meeting may be protracted when circumstances will justify it, and also that the twenty-fifth of the same month be observed as a day of thanksgiving, and that each preacher be requested to preach one sermon on the occasion. William V. Daniel, John W. Brouse." 
"Resolved, that during this conference year we will endeavor at the close of each day in the twilight, especially to remember our brethern of the Indiana conference at a throne of grace, praying each for the others, that we may be preserved from evil, and that we may greatly increase in knowledge, in holiness, and in usefulness, and be preserved blameless with the coming of our Lord Jesus Christ. C. W. Ruter, A. Eddy."

The report of the committee on book and periodicals was accepted and filed.

"Resolved, that the payment of the balance due on the bill for Bishop Roberts' portrait be deferred till next conference, and Brothers Cooper and Nutt be a committee to appropriate the amount collected. G. M. Beswick, George W. Ames." Adopted.

The committee on periodicals made their report, which was adopted and filed among conference papers, and the following resolution was adopted: "Resolved, that we consider it the duty of each minister in this conference to exert himself to sustain our periodicals generally, and especially the Western Advocate and Ladies Repository."

The committee to count the votes for visitors to the university reported the following persons elected, viz: C. W. Ruter, L. W. Berry, A. Eddy, W. H. Goode, A. Wiley, G. M. Beswick, J. C. Smith and S. T. Gillett, and that James Havens and Aaron Wood were a tie, whereupon conference elected James Havens.

Resolved, that the money raised to make a life director in the Bible Society be so applied, as to make that itinerant preacher a life member who has traveled the greatest number of years in the state of Indiana, E. Patrick." Adopted.

The committee on division of the conference reported, and the report was accepted, and the resolutions appended were disposed of as follows:

Resolved, that it is expedient to divide the Indiana 
conference. Adopted. Resolved, that the National road be the line, and that all towns from the state line, east to Indianapolis, on this road, be included in the Northern conference, and that Indianapolis, and all the towns west to the state line, be included in the Southern division of the conference." The first part as to National road being the line, adopted, the second postponed with directions to presiding elders to prepare two plans. Resolved, that the Southern conference be called the South Indiana Conference, and the northern, North Indiana Conference. Adopted. Resolved, that the superannuated preachers, widows and orphans be divided between the conferences, according to the numerical strength. Adopted.

Resolved, that the board of trustees of the university be divided into two classes: the first twelve; the second thirteen; and the first hold the same relation to the North Indiana Conference as the whole board does at the present time to the Indiana conference; and the second class hold the same relation to the South Indiana Conference. Adopted. Resolved, that the visitors to the Asbury University be appointed five in one conference, and four in the other, alternately; the highest number being first appointed by the South Indiana Conference. Adopted.

Resolved, that the preachers along the National road, be requested to arrange their work during the present year, that the societies near the line on each side may fall in case of a division into the separate conferences. Adopted.

Resolved, that the managers of the Preachers' Aid Society be divided into classes of four and five, and that the vacancies in the former be supplied by the North, and in the latter by the South Indiana Conference, according to the provisions of the charter." Postponed.

Resolved that the proceeds of the Preachers' Aid 
Society be divided between the conferences in proportion to the members of conference in each division." Adopted.

The pastoral address was presented and read and the following resolutions adopted by a rising vote: "Resolved, that the addresses be adopted by the conference signed by the president and countersigned by the secretary, and forwarded to Cincinnati with a request to the editors of the Western Christian Advocate and German Apologist, to publish it at their earliest convenience. C. W. Ruter, Allen Wiley."

Resolved, that the presiding elder of the Greencastle district and secretary of the conference be a committee on the distribution of the missionary debt, and that they make the distribution according to the numerical strength, and that they report through the Western Christian Advocate, as soon as possible." Adopted.

"Resolved, that the preachers raise the respective sums assigned them by the 4th of July, 1843, and report the same to the assistant treasurer at Cincinnati. J. A. Brouse, J. W. Sullivan." Adopted.

"Resolved, that this conference request each preacher in charge to inquire into the state of our church property relative to deeds and trustees, and that they be required to report to a committee, to be appointed at the next conference." Which was adopted.

On motion, resolved that when conference adjourns it adjourn to meet at 2 o'clock $\mathrm{p}$. $\mathrm{m}$. in the new meeting house in this town. C. W. Ratiter, A. Eddy. Adopted.

Resolved, that the secretary of this conference be directed to forward any of the papers of this conference (at his discretion) to the Western Christian Advocate for publication. Allen Wiley, A. Eddy. Adopted. 
The time of adjournment having arrived, conference was closed with prayer by Brother Havens.

Wednesday afternoon, October 26th, 1843. Conierence met pursuant to adjournment, and was opened with reading, singing and prayer, by Brother $H$. S. Talbott, and the Journals were read and approved.

Resolved, that a vote of thanks be respectfully tendered to the citizens of Centerville for their kind hospitalities to the members of the Indiana conference during its present session, and that this expression be publicly announced by the preacher who shall next Sabbath officiate in this place. C. W. Ruter, A. Eddy. Which was unanimously adopted by a rising vote.

The committee appointed to inquire in reference to the preaching during this conference, made a verbal report, and were discharged from the further consideration of the subject.

Some resolutions in reference to the Sabbath School Union were now taken up and adopted as follows, viz:

Resolved, that the secretary of this conference be instructed to forward the Sunday school report of this conference to the secretary of the Sunday School Union, of the Methodist Episcopal Church at New York.

Resolved that Augustus Eddy be the vice president of the Sunday School Union of the Methodist Episcopal Church for the Indiana Conference.

Resolved that we recommend to all our Sunday schools to take the Sunday School Advocate, published by the book agents at New York.

Resolved that we recommend to all our Sunday schools to take a quarterly collection averaging a penny per quarter for each member of the school in aid of the funds of the said union, and forward the amount to the vice president for this conference.

The committee to disburse the funds of the Preach- 
ers' Aid Society, report they have distributed as follows :

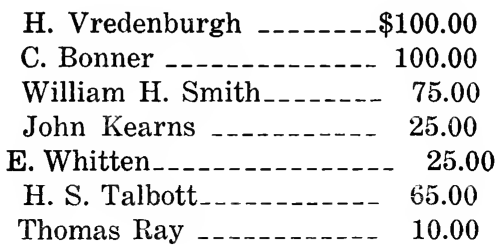

Which report was read and adopted.

Resolved by this conference that the managers of the Preachers' Aid Society be respectfully requested not to employ any agent for the ensuing year. S. C. Cooper, A. Eddy. Which was not adopted.

Prayer by the Bishop was then offered, the appointments read, and on motion, Warren Griffith was granted a location at his own request, and conference was closed with the benediction.

THOMAS A. MORRIS.

M. SIMPSON, Secretary.

APPOINTMENTS FOR 1842.

Madison District.

C. W. Ruter, Presiding Elder.

Madison-

Wesley Chapel-Augustus Eddy.

Third Street-William M. Daily.

Paris-William Maginnis.

Vernon-Lewis Huriburt.

Canaan-Hayden Hays, John S. Winchester.

Vevay-James Crawford, H. J. Durbin.

Rising Sun-John W. Sullivan, Silas Rawson.

Lawrenceburg-Amos Bussey, Thomas M. Eddy.

Wilmington-James Jones, Milton Mahen.

Lawrenceburg German Mission-George A. Breunig. 
Charlestown District.

E. G. Wood, Presiding Elder.

New Albany-

Wesley Chapel-G. C. Beeks.

Centenary Church-R. S. Robinson.

Corydon-Thomas Ray, A. Wilkerson.

Greenville-Emmonds Rutledge.

Salem-Charles Romer, C. Mapes.

Leesville-Thomas E. Spillman.

Brownstown-Seth Smith.

Lexington-John Kiger, J. Corwine.

Charlestown-C. B. Jones, J. Whiteman.

Jeffersonville-William V. Daniel.

\section{Evansville District.}

H. S. Talbott, Presiding Elder.

Evansville-John Kearns.

Mt. Vernon-A. Robinson, J. H. Clippenger.

Cynthiana-A. B. Nesbit, E. Lilleston.

Princeton-Elijah Whitten.

Petersburg-Eli C. Jones.

Booneville-William Bratton.

Rockport-D. S. Elder, P. I. Beswick.

Rome-Edward Oldham.

Paoli-Peter R. Guthrie.

Evansville German Mission-Peter Schmucker.

Bedford District.

John Miller, Presiding Elder.

Vincennes Station-Samuel Reed.

Bruceville-John A. Decker.

Washington-John Talbott.

Orleans-George W. Walker.

Bedford-Williamson Terril.

Springville-James R. Williams.

Bloomington-Isaac Owen. 
Richland Mission-Wesley Dorsey.

Carlisle-John Daniel.

New Lebanon-Stephen Ravenscroft.

Brown Mission-Daniel McIntyre.

\section{Greencastle District.}

G. M. Beswick, Presiding Elder.

Greencastle-Ebenezer Patrick, J. M. Stallard.

Putnamville-John B. Birt.

Russellville-C. Swank, Thos. S. Crawford.

Rockville-George W. Ames.

Terre Haute-Joseph Marsee.

Prairieton-Ezra L. Kemp, John R. Tansey.

Rossville-Isaac Crawford.

Spencer-Philip May, E. Genung.

Martinsville-John B. DeMott, Jas. Scott, sup.

Mooresville-Asa Beck, H. C. Benson.

Indiana Asbury University - M. Simpson, President; Wm. C. Larrabee and Cyrus Nutt, Professors; S. C. Cooper, Agent; E. R. Ames, Missionary Secretary.

\section{Crawfordsville District.}

J. C. Smith, Presiding Elder.

Crawfordsville-Samuel Brenton.

Ladoga-Richard Hargrave.

Conville-J. White, E. W. Caldwell.

Covington-J. J. Cooper, D. DeMott.

Newtown-J. S. Barwick, Jno. W. Parrot.

Augusta-D. F. Stright.

Newport-Thomas Bartlett.

Alamo Mission-J. B. Mershon.

Perrysville-Amasa Johnson.

Lafayette District.

C. M. Holliday, Presiding Elder.

Lafayette Station-Hawley B. Beers. 
Dayton-Allen D. Beasley, J. N. Newland.

Delphi-Draper Chipman, J. Cozad.

Logansport-Wm. Wilson.

Frankfort-Jacob Colclazer.

Lebanon-John Edwards.

Rensselaer Mission-Geo. W. Stafford.

Monticello-B. T. Griffith.

Williamsport-H. N. Barnes.

Independence-Wm. M. Fraley, Samuel B. F. Crane.

Pittsburg Mission-R. Rowley.

South Bend District.

Wm. H. Goode, Presiding Elder.

South Bend-Zachariah Games, W. L. Huffman.

Mishawaka-E. Holstock.

Goshen-Enoch Wood, J. M. Stagg.

Lagrange-W. J. Forbes, J. C. Medsker.

Laporte-Aaron Wood, one to be supplied.

Valparaiso-Wade Posey.

Yellow River Mission-Eventus Doud.

Warsaw-Orange V. Lemon, P. E. Royce.

Steuben-E. S. Blue, John P. Jones.

\section{Fort Wayne District.}

B. Westlake, Presiding Elder.

Fort Wayne-Geo. M. Boyd.

Decatur-J. Sparks.

Auburn-Allen Skillman.

Rochester-Ancil Beach, Nelson Greene.

Winnemeck Mission-Lealdes Forbes.

Peru-Wm. F. Wheeler, Wm. G. Stonex.

Eel River-Charles W. Miller.

Upper Wabash Mission-Robert H. Calvert.

Huntington Mission - Nathan S. Warden, John Richey, sup. 


\section{Winchester District.}

Robert Burns, Presiding Elder.

Winchester-Barton H. Bradbury, Arthur Badly.

Portland-J. W. Bradshaw.

Minceytown-John H. Hull.

Granville-Hezekiah Smith.

Marion-J. S. Donaldson, Wm. Anderson.

Andersontown-Brinton Webster.

Pipe Creek Mission-Samuel C. Swayze.

Bluffton-H. H. Badly.

Newcastle-Chas. B. Davidson.

Cambridge and Dublin-John L. Smith.

\section{Connersville District.}

A. Wiley, Presiding Elder.

Connersville-James Hill, J. Bruner.

Centreville-Joseph Tarkington, Thos. A. Goodwin.

Richmond-Francis A. Conwell.

Liberty-Wm. W. Hibben, L. M. Reeves.

Brookville-Miltiades Miller, Oliver H. P. Ash.

Fairfield-Wm. Morrow.

Greensburg-Fernandes C. Holliday.

Milroy-John H. Bruce, Samuel P. Crawford.

Milford-Landy Havens.

Versailles-Francis H. Carey, F. F. Sheldon.

\section{Indianapolis District.}

James Havens, Presiding Elder.

Indianapolis-

Western Charge-Lucien W. Berry.

Eastern Charge-John S. Bayless.

Noblesville-John L. Kelly.

Westfield-John V. R. Miller.

Franklin-Miles Huffaker.

Shelbyville-Jacob Myers, James Webb.

Rushville-Wm. C. Smith, A. Paris. 
Knightstown-George Havens, G. H. McLaughlin. Greenfield-George W. Bowers.

Pendleton-J. Miller, I. J. Crouch.

Columbus-John W. Melander, J. D. Templin.

William Shreck, transferred to Missouri Conference.

Isaac McElroy, J. F. Truslow, David Crawford and J. F. Randolph, transferred to Arkansas Conference.

J. Kisling, transferred to Ohio Conference.

Journal of the Twelfth Annual Session of the Indiana Conference, began and held in the Old School Presbyterian Church in Crawfordsville, October 18, 1843.

Wednesday morning, 9 o'clock. Conference met pursuant to appointment and was opened by Bishop Andrew by singing and prayer.

The list was then called by M. Simpson, the secretary of the last conference, and the following members were found to be present, viz.: C. W. Ruter, A. Eddy, Wm. M. Daily, Wm. M. Ginnes, Lewis Hurlbutt, Hayden Hays, James Crawford, John W. Sullivan, Silas Rawson, Samuel T. Gillet, Amos Bussey, James Jones, E. G. Wood, G. L. Beeks, Thomas Ray, Emmons Rutledge, Charles Bonner, Seth Smith, John Kiger, C. B. Jones, H. S. Talbott, John Kearns, Anthony Robinson, Elijah Whitten, Eli C. Jones, Edward Oldham, Wm. W. Hibben, J. A. Brouse, Wm. Morrow, John H. Bruce, Landy Havens, Francis H. Cary, Peter R. Guthrie, John Miller, Samuel Reed, John Talbott, George W. Walker, John R. Williams, Wesley Dorsey, John Daniel, Stephen Ravenscroft, Daniel McIntyre, G. M. Beswick, Ebenezer Patrick, J. M. Stallard, John B. Birt, Joseph Marsee, Ezra L. Kemp, Isaac Crawford, Philip May, Elam Jenung, John B. De Motte, Asa Beck, M. Simpson, C. Nutt, W. C. Larabee, S. C. Cooper, E. R. Ames, James Havens, L. W. Berry, J. 
C. Harbin, J. S. Bayless, John L. Kelly, J. C. Smith, Samuel Brenton, J. White, Daniel DeMott, Thomas Bartlett, Amasa Johnson, C. M. Holliday, Allen D. Beasley, Draper Chipman, Jacob Colclazer, John Edwards, W. L. Huffman, E. Holstock, Aaron Wood, Burris Westlake, Arred Beach, Charles W. Miller, Robert H. Colvert, Robert Burns, J. S. Donaldson, John L. Smith, Allen Wiley, James Hill, Joseph Tarkington, Thomas A. Goodwin, Francis A. Conwell, J. V. R. Miller, Jacob Myers, Wm. C. Smith, George Havens, J. Miller.

The conference then proceeded to elect a secretary by ballot, and upon counting the votes, M. Simpson having received a majority of all the votes, was declared duly elected.

On motion of Brother Wiley the hour of assembling was fixed at eight o'clock in the morning and the time of adjournment at 12 .

On motion of Brother Ames, Brothers J. C. Smith, Samuel Brenton and Richard Hargraves were appointed a committee to select preachers during conference and superintend the services of public worship.

The conference then proceeded to the election of three stewards by ballot, and the votes being received, on motion of Brother Eddy, the election was decided by a plurality of votes, whereupon Brothers S. C. Cooper, W. V. Daniel and C. Nutt were declared duly elected.

The conference proceeded in the same manner to elect three stewards to disburse the funds received from the Preachers' Aid Society, in accordance with the provisions of the constitution of said society, whereupon Brothers E. R. Ames, A. Eddy and L. W. Berry were declared duly elected.

On motion of Brother Ames a committee was appointed on a communication from book agent at New 
York and S. P. Gillet, E. Patrick and J. A. Brouse, were appointed said committee.

On motion of Brother Ruter, the by-laws of the first session of this conference were read and adopted by consent, together with the rule in reference to closed doors.

On motion of Brother Edwards, the house fixed their bar the whole lower floor except the rear seat.

The bishop laid before the conference a communication from the New York Conference, in reference to certain amendments of our general rules, which having been read by the secretary, on motion of Brother Ames was laid upon the table.

On motion, conference appointed Brothers Samuel Brenton, James Jones and George W. Ames a committee to receive the report from the preachers on the subject of church property.

On motion of Brother Ames, Professor Larabee was requested to deliver an address on education on next Friday afternoon at 3 o'clock.

The bishop also laid before the conference an exhibit of the state of the New York book concern, which was read by the secretary and filed among the conference papers.

The bishop addressed the conference a few minutes in a very interesting and impressive manner, in reference to the duty of the conference to preserve purity of doctrine and administration of discipline.

The second question of the minutes was taken up, viz.: Who remain on trial? And the characters of H. J. Durbin, Elijah Lilliston, Philip J. Beswick, Jacob Cozad, Nelson Green, John P. Jones, Arthur Badley, John R. Tarsey, Isaac J. Crouch, John S. Winchester, John H. Clippinger, Wm. Anderson, Samuel P. Crawford, Thomas M. Eddy, Wm. G. Stonex, John W. Parrot, Oliver H. P. Ash, F. F. Sheldon, Elisha W. 
Cadwell and G. H. McLaughlin, were examined and passed, and they were continued on trial.

On motion of Brother Wiley, it was resolved that when conference adjourns it adjourns to meet at 2 o'clock, to take up the resolutions on the subject of the division of the conference.

James Webb was discontinued on account of ill health, and Thomas C. Crawford was not continued on trial.

Some notices were given and conference was closed with the benediction by the bishop.

Wednesday afternoon, 2 o'clock. Conference met pursuant to adjournment, and was opened with singing and prayer by Brother Wiley.

The subject of the division of conference having been made the order of the day for this afternoon, the secretary read the resolutions of last conference on this subject, whereupon Brother Beswick presented the following resolution: "Resolved that in the opinion of this conference, it is inexpedient to divide at this time," which resolution was lost.

On motion of Brother A. Wood the second resolution of last year's report was called up, viz.: "Resolved that the National Road be the line, and that all the towns from the state line east to Indianapolis on this road be included in the Northern Conference, and that Indianapolis and all the towns west to the state line be included in the southern division of the conference." Brother J. C. Smith moved on referring the towns east of Indianapolis to the south and Indianapolis and those west to the north, which was lost by a vote of 54 to 56 .

A motion was made by Brother Wood that all the towns on the road be given to the south, which was lost. An amendment was made by Brother Bayless that the two charges in Indianapolis be so divided that the eastern charge be in the northern and the west- 
ern in the southern conference. Which was carried. On motion the town of Terre Haute was placed in the Northern Conference. Brother Beeks then moved a reconsideration of the vote dividing Indianapolis, which was lost; when after considerable discussion the resolution passed in the following form: Resolved that the National Road be the line, and that the eastern charge in Indianapolis, with all the towns east, be placed in the Northern Conference, and that the western charge in Indianapolis, with all the towns west, be placed in the Southern Conference except Terre Haute, which is placed in the Northern Conference.

The eighth resolution respecting division was then adopted as follows, viz.: Resolved that the managers of the Preachers' Aid Society be divided into classes of four and five, and that the vacancies in the former be supplied by the north, and in the latter by the South Indiana Conference, according to the provisions of the charter.

On motion of Brother Wiley the stewards are requested to divide the claimants among the superannuated preachers, widows and orphans equally between the two conferences.

On motion of Brother Cooper the name of the southern division is to be called the Indiana Conference, and the name of the northern division the North Indiana conference.

On motion of Brother Wiley the Southern Conference shall fill all vacancies in the trustees of the Indiana Asbury University until the number of thirteen shall be filled, and then each conference shall fill its own vacancies.

After some notices were given, conference was closed by the bishop with the benediction.

Thursday morning, October 19, 1843. The con- 
ference met pursuant to adjournment and was opened with singing and prayer by Brother H. S. Talbott.

The roll was called and the journals read and approved, and on motion of Brother Wiley the calling of the list was hereafter dispensed with. Brother Cooper, from the committee on the bishop's portrait, made a report, stating the entire expense of painting, framing and curtaining said portrait to be $\$ 66.58$, and that the amount paid was $\$ 51.40$, leaving a balance of $\$ 15.18$ unpaid, and asking that a collection be taken up forthwith to defray said amount, which report was accepted and filed among the conference papers. A collection was taken up, and on motion of Brother Ames the surplus, if any, shall be appropriated to the missionary cause. Upon counting the funds, the collection amounted to $\$ 18.72$. Surplus $\$ 3.54$.

Brother Cooper, from a committee appointed to correspond with the widow of Brother Barnes as to appropriating the dividend made to her child, to the payment of Brother Barnes' book debt, reported that she declined allowing said appropriation; which report was accepted and filed away.

The third question was now taken up, viz.: "Who are admitted into full connection?" and the candidates having been called forward were addressed by the bishop at some length in reference to ministerial character and duty, and were examined according to the form prescribed in the discipline, and their characters were severally examined and passed, and they were admitted into full connection and elected to deacons' orders as follows, viz.: Charles Mapes, Alfred Nesbet, James Corwin, Jacob Bruner, Samuel C. Swayze, Milton Mahen, Horatio N. Barnes, Orange V. Lemon, Elijah S. Blue, John C. Medsker, Jacob Whiteman, Daniel S. Elder and Isaac M. Stagg.

The characters of James H. Newland, Jesse Sparks, Henry H. Badley and Wm. Bratton were examined and 
passed, and they were admitted into full connection, Brother Terrall being already an elder, and Brother Bradshaw having been two years a deacon, was elected to elder's orders.

James D. Templin and Hezekiah Smith were discontinued at their own request and Absalom Paris was dropped, having been excommunicated from the church.

Pleasant E. Boyse, a probationer for the first year, was discontinued. The following resolution was presented: "Resolved that the preachers in charge of districts, circuits and stations be, and they are hereby required to conduct all church trials with closed doors, and that no person who is not a member of the church shall be present, unless introduced as a witness, and then only as long as will be necessary to give in his testimony. (S. C. Cooper, C. Nutt). And the resolution was passed after all was stricken out after the words "closed doors."

After some notices were given, conference adjourned and was closed with the benediction by the bishop.

Friday morning, October 20, 1843. Conference met pursuant to adjournment, and was opened by reading, singing and prayer by Brother Elliott of the Ohio Conference, and the journals were read and approved.

Brother Wright, one of the western Book agents, presented the annual exhibit of the western book concern, with the amount of sales during the last fifteen months, and the amount of indebtedness in the bounds of each conference.

The fifth question of the minutes was taken up, viz.: "Who have been elected and ordained elders this year?" And the characters of John L. Smith, Peter R. Guthrie, Edward Oldham, James R. Williams, John V. R. Miller, Rosseter Rowley, Stephen Ravenscroft, John L. Donaldson, Enoch Holdstock, Wm. Wil- 
son, Landy Havens, George W. Ames, Draper Chipman, Lealdes Forbes, Wesley Dorsey, Samuel Reed, Wm. F. Wheeler, Walter L. Huffman, George Havens and Eventus Doud were severally examined and passed and were elected to elders' orders, and Brother Wilson was placed in a superannuated relation.

The first question of the minutes was then taken up, viz.: "Who are admitted on trial?" And the following persons being properly recommended, were received as follows, viz.: From the Madison District, Samuel Hicks ; Charlestown District, Thomas H. Sinix, George B. Jocelyn, Samuel H. Porter, Francis A. Hester, James Mitchell; Evansville District, James Ingle, John W. Julian; Bedford District, Thomas J. Ryan, Orvell Boyden; Greencastle District, George W. Warner, Benjamin Winans; Crawfordsville District, Hugh Wells, John B. Johnson, Michael Johnson; Lafayette District, Franklin Taylor; South Bend District, Lonson W. Monson, Samuel Lamb; Ft. Wayne District, Addison Merrill, Elihu Anthony; Winchester District, George Guild, John Leach; Connersville District, John C. Robbins, James C. Reed, Abraham Cary, Erastus Lathrop, Zelottes S. Clifford, John Wallace; Indianapolis District, S. A. Ballingall; Madison District, Luther Taylor.

Washington Malick, Thomas S. Gunn and Warren Griffeth were readmitted into the traveling connection.

Joseph Ockerman, a candidate for readmission, and James M. Dougherty, a candidate for admission from the Winchester District, were not received.

The vote by which Thomas C. Crawford was discontinued was reconsidered, and he was continued on trial.

The place of Brother Wm. H. Goode in the Mission Committee was filled by the appointment of Brother L. W. Berry. 
After some notices were gvien, conference was closed with the benediction by the bishop.

Saturday morning, October 21, 1843. Conference met pursuant to adjournment, and was opened with reading, singing and prayer by Brother Eddy, and the journals were read and approved.

The secretary was directed to enter the names of the Mission Committee as follows, viz.: C. W. Ruter, S. C. Cooper, A. Wood, R. S. Robinson and L. W. Berry.

The recommendations of local preachers for deacon's orders were taken up and the following brethren were elected to deacon's orders, viz.: From the Charlestown District, John F. Willey, Solomon Jacob and James Rodgers. Evansville DistrictHorace L. Williams. Bedford District_Martin Hail, Nathan Hinkle and James F. Harvey. Crawfordsville District-Thomas Birch. Lafayette District-Lewis Chaney and John Robinson. South Bend DistrictThomas Brown. Connersville District-Thomas Kennedy. Greencastle District-W. G. Gregory, John E. Burton, Wm. C. Cummins, Thomas H. Rucker, J. Nichols and J. Marshall, and John Gillespy recommended from the same dstrict was not elected.

On motion of Brother Ruter, Brother Malick had leave of absence until Monday.

The consideration of local preachers recommended for elder's orders was now taken up and the following brethren were elected elders, viz.: From Madison District, Hosier J. Durbin; Charlestown District, Shiveral Garner, Thomas Ryan, Jacob Schwartz, George Schwartz and Samuel Bottorff. They have certified to their belief in the doctrines and attachment to the discipline of the Methodist Episcopal Church.

On motion Brother Beeks obtained leave of absence until Monday.

The parchment of John Robbins was presented by Brother Wood and a statement made that he had been 
expelled from the church during the past year, also a certificate by the quarterly meeting conference that he had been restored. The question was submitted to the chair whether an expelled member could be restored to ministerial standing without his first joining the church as a private member and the chair decided that he could not. The parchment was accordingly filed among the conference papers.

The fourth question of the minutes was taken up, viz.: "Who are the deacons?" And the characters of Charles W. Miller, Daniel McIntyre, John M. Mellander, Robert H. Colvert, Brenton Webster, Allen Skillman, Charles B. Davidson, John B. Derrott, Asbury Wilkinson, Thomas A. Goodwin, Wm. C. Smith, Eli C. Jones and Hayden Hays were examined and passed.

The examination of the characters of elders commenced, and the presiding elders gave a statement of the work on their several districts, together with a sketch of their personal experience, and the characters of C. W. Ruter, Enoch G. Wood, H. S. Talbott, John Miller, G. M. Beswick, J. C. Smith, C. M. Holliday, Wm. H. Goode, Aaron Wood, Burris Westlake, Robert Burns, Allen Wiley and James Havens were examined and passed, and Brother Burns was placed in a superannuated relation.

On the bishop announcing the sums ready for the conference, the conference voted to draw on the Book Concern for the sum of five hundred dollars and on the chartered fund for forty dollars, and Brother Berry announced that the managers of the Preacher's Aid Society had forwarded to the conference five hundred dollars in old scrip.

After some notices were given conference was closed with the benediction by the bishop.

Monday morning, October 23, 1843. Conference met pursuant to adjournment and was opened with 
reading, singing and prayer by Brother Ruter, and the journals were read and approved.

The examination of the characters of the elders was resumed, and the characters of Augustus Eddy, Wm. M. Daily, Wm. McGinnis, Lewis Hurlbutt, James Crawford, John W. Sullivan, Silas Rawson, Samuel T. Gillet, Amos Bussey, James Jones, G. C. Beeks, R. S. Robinson, Thomas Ray, Emmons Rutledge, Charles Bonner, Seth Smith, John Kiger, S. B. Jones, Wm. V. Daniel, John Kearns, Anthony Robinson, Elijah Whitten, John Talbott, Isaac Owen, John Daniel, Ebenezer Patrick, J. M. Stallard, John B. Birt, Cornelius Swank, Joseph Marsee, Ezra L. Kemp, Isaac Crawford, Philip May, Elam Jenung, James Scott, Asa Beck, M. Simpson, W. C. Larabee, C. Nutt, S. C. Cooper, E. R. Ames, Samuel Brenton, Richard Hargrave, J. White, Daniel DeMott, J. S. Barwick, D. F. Straight, Thomas Bartlett, J. B. Merchen, Amasa Johnson, H. B. Beers, A. D. Beasley, Jacob Colclazer, John Edwards, George W. Stafford, B. L. Griffeth, Wm. M. Frailey, Zachaniah Games, Enoch Wood, W. J. Forbes, Wade Posey, Geo. M. Boyde, Ancil Beach, John H. Hall, James Hill, Joseph Tarkington, Francis A. Colwell, Wm. W. Hibben, L. M. Reeves, Miltiades Miller, Wm. Morrow, John H. Bruce, F. H. Carey, L. W. Berry, J. S. Bayless, John L. Kelly, Miles Huffaker, Jacob Myers, Jacob Miller and Peter Schmucker were examined and passed.

The characters of John Decker, F. C. Holliday and George W. Bowers, were examined and passed and they were placed in a superannuated relation.

The character of Thomas F. Spillman was examined and passed and he was granted a located relarton.

The name of John Ritchie having been called, and he having two years since been requested by the conference to locate, and having during the last year declined to fill the appointment, which was given him as 
a supernumerary, his presiding elder, understanding from him that he designed to locate at this conference, and some allegation having been made against him, and he not being present to answer, the conference located him, and directed his presiding elder to withhold his certificate of location until the allegations against him shall have been properly examined.

The characters of the superannuated preachers were now taken up, and the character of Wm. $\mathrm{H}$. Smith, H. Vredenburgh, Wm. Shanks, James L. Thompson, J. C. Harbin, Wm. Knowles were examined and passed, and they were continued in a superannuated relation and Brother Knowles was elected to elders' orders.

The characters of John H. Brouse, H. S. Dane and Thomas J. Brown, were examined and passed and placed in an effective relation.

The name of George H. Breuing having been called, the following resolution was adopted: Whereas Brother Breuing was transferred to this conference without knowledge from the Ohio Conference, and whereas he was at the time of his transfer a broken down or superannuated man, and is unable and has been unable to do effective work, and whereas the conference believes, it is a violation of the rights of annual conferences to have men unable to labor transferred to them without their consent, to become pensioned upon their funds: Therefore, Resolved, that while the character of Brother Breuing be passed, the conference request the bishop to transfer Brother Breuing to the Ohio Conference, and the Indiana Conference do hereby protest against the propriety of such transfers, and especially against the Episcopacy superintending the Ohio Conference at its session, making appointments affecting the stations and interests of the Indiana Conference.

On motion of Brother Enoch Wood a committee 
was ordered to take into consideration the propriety of removing the remains of Bishop Roberts to some other place, when the following resolution was presented: "Resolved that a committee of three be appointed to draft resolutions, expressive of the sense of this conference of the character and worth of the late Bishop Roberts. J. C. Smith, John Miller, James Havens." Whereupon C. W. Ruter, M. Simpson and Allen Wiley were appointed to attend to both above named subjects.

On motion of Brother Wiley it was resolved that when conference adjourn it adjourn to meet at 2 o'clock to go into the election of delegates to the next general conference.

On motion, conference proceeded to select the places for holding the next conferences, and the eastern charge of Indianapolis and Ft. Wayne being in nomination for the northern division, Ft. Wayne was selected, and Bloomington, Madison, New Albany and Evansville being in nomination for the southern division, Bloomington was selected. And in case the conference should not be divided, Indianapolis was selected as the place of holding conference.

On motion of Brothers S. C. Cooper and H. S. Talbott it was "Resolved that our delegates to the next general conference be and they are hereby instructed to use their best efforts to prevent our German Missions from being disconnected from our regular work."

On motion of Brother Eddy it was "Resolved that the superintendents be requested to fix the times of holding the Indiana and North Indiana Conferences as early in September as possible."

After some notices were given, conference was closed with the benediction by the bishop.

Monday afternoon, October 23, 1843. Conference met pursuant to adjournment and was opened with 
prayer by M. Simpson, and the journals were read and approved.

Conference proceeded to the order of the day, which was the election of delegates to the next general conference, when, upon counting the votes, $M$. Simpson, A. Wiley, E. R. Ames, John Miller, C. W. Ruter, Aaron Wood, Augustus Eddy and James Havens, having received a majority of all votes upon the first ballot, were declared duly elected, and John C. Smith and Richard Hargrave were elected reserve delegates.

Conference proceeded to the election of nine visitors to the university, and, upon the tickets being received, Brothers Daily and Beach were appointed a committee to count the votes and report to conference tomorrow morning.

On motion, conference adjourned and was closed with the benediction by the bishop.

Tuesday Morning, October 24th, 1843.

Conference met pursuant to adjournment and was opened with reading, singing and prayer by Brother James Jones, and the journals were read and approved.

The committee appointed to count to votes for visitors reported the following persons duly elected, viz.: L. W. Brry, J. C. Smith, A. Wiley, G. M. Beswick, E. G. Wood, S. T. Gillett, A. Eddy, E. R. Ames and C. W. Ruter.

The Stewards made their report, which was adopted and filed among the Conference papers.

Conference voted to apply the appropriations made to Widow Barnes' child toward the liquidation of Brother Barnes' book debt, and that Brother s. C. Cooper apply the money now in his hands in the same way.

The Secretary read the statement of meeting-houses, parsonages, Sabbath schools, local preachers, members 
and mission moneys, which was filed among the Conference papers.

The committee on distribution of the funds from the Preachers' Aid Society made their report, which was accepted and filed among the Conference papers.

Conference proceeded to the election of trustees for Indiana Asbury Univrsity, and J. W. Wines, E. R. Ames and J. H. Cravens were elected in room of Havens R. Hardesty and James Nosler.

Brother Wright made a statement of the case of Brother Belotte, as noticed in the journals of last Conference, and on motion of Brother E. G. Wood, Conference directed the preacher in charge of the place where Brother Belotte resides to proced against him to collct the money, according to discipline.

Brother Wright made a report in reference to the debt of Brother Oglesby, and it was left in the hands of the preacher in charge of Third Street, Madison.

The account of J. Williams was placed in the hands of the preacher in charge of the Madisonville Circuit.

The account of Brother Ballow was continued in the hands of the preacher in charge of Ft. Wayne.

The account of Brother Amasa Johnson was given to the presiding elder in whose district he may be, to be properly secured.

The committee on distributing the funds of the Preachers' Aid Society reported the distribution as follows :

E. G. Wood $\$ 50.00$

W. H. Smith 30.00

H. Vredenburgh 50.00

J. L. Thompson 30.00

R. Hargrave 25.00

H. S. Talbott 25.00

J. Keans 25.00

E. Whitten 30.00

J. C. Harbin 20.00 


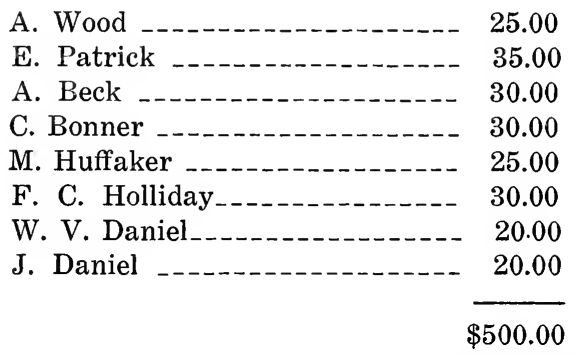

Brother Wright read a paper on the project of publishing a social and domestic library, and the following resolution was presented: "Whereas, the Book Committee at Cincinnati has submitted for the consideration of this conference the plan of a social and domestic library, to embrace a great variety of books for popular reading, which we esteem a very necessary and important measure, worthy of the adoption of the church. Therefore, Resolved, by the Indiana Annual Conference that we recommend the contemplated enterprise to the consideration and favorable action of the next general conference, and that the delegates from this conference be requested to use their influence to have the measure adopted by that body." After several motions the resolution was divided and amended and passed as follows: "Resolved by the Indiana Annual Conference that we recommend the contemplated enterprise to the careful consideration and action of the next general conference."

The committee on the death of Bishop Roberts reported the following resolutions: 1st, Resolved, That we regard with deep gratitude that providence which granted us the privilege of claiming for the period of twenty-four years Bishop Roberts as a fellow citizen and a patriarchal minister resident among us. 2d, Resolved, That in view of the intellectual and moral worth of Bishop Roberts and his kind regard for us 
and the whole church, his death be considered as a paternal bereavement to the ehurch in general and to the Indiana Conference in particular, which calls for proper humiliation and resignation. 3d. Resolved, That we shall be greatly wanting to ourselves, and the cause of God, if we do not imbibe his spirit, and imitate his wholesome and Godly examples. 4. Resolved, That the remains of the venerable Bishop (the widow consenting) be removed from the present obscure lodgment and be transferred to Greencastle. 5. Resolved, That a suitable monument or tombstone be erected to the memory of the Bishop. 6. Resolved, That the expenses incurred in carrying into effect the last two resolutions be met by the Indiana Conference, and should the Conference be divided, by the two Conferences jointly, according to their numerical strength. 7 . Resolved, That Bishop Soule be requested to furnish a suitable epitaph or inscription for the Bishop's tomb. 8. Resolved, That M. Simpson and the Presiding Elder of the Greencastle District and the district in which Bishop Roberts was buried be a committee to carry into effect the foregoing resolutions. 9. Resolved, That the foregoing resolutions be spread on the journals of this Conference and a copy of them be forwarded to the aged widow of the Bishop, and also a copy be furnished the editor of the Western Christian Advocate for publication, with a request that the other Methodist papers copy. C. W. Ruter, M. Simpson, Allen Wiley."

On the presentation of the parchment of Bishop Roberts, on the traveling trunk of Bishop Asbury, formerly in the possession of Bishop Roberts, it was resolved that the Conference permit Dr. Elliott to use them as he may need in the preparation of the Bishop's life, and then that they be deposited in the cabinet of the Asbury University.

On motion of Brother Wiley, it was "Resolved, That 
by precept and example we will use our influence to prevent the use of tobacco in our houses of worship."

A memorial in reference to the Indianapolis Institute was read and referred to a committee consisting of Brothers Berry, Larrabee and Bayless.

A memorial was presented from the Eastern charge in Indianapolis concerning church property, which was referred to a committee consisting of Brothers Eddy, Cooper and Gillet.

The committee on church property made a report, which on motion of Brother Eddy was laid on the table.

On motion of Brother Conwell the vote by which Brother Harbin was continued in a superannuated relation was reconsidered, and he was placed in an effective relation.

The following presents an abstract by districts of the statistics of this Conference:

In addition of the foregoing amount of mission money of $\$ 2,537.77$

There was collected at the Conference anniversary

Making the total amount of missionary collections

From the Steward's report the total amount of claims was $39,681.63$

The total amount of receipts $25,715.80$

Leaving a deficit of $\$ 13,965.83$

The fifth collection amounted to _- $\$ 267.41$

Divided from Book Concern_...- 500.00

Divided from chartered fund_-_- $\quad 40.00-\quad \$ 807.41$ Making a dividend to claims where receipts were under 27 1-4 per cent., which dividend was distributed as per report.

After a number of notices were given, Conference adjourned, and was closed with the benediction by the Bishop. 
CIRCUIT-RIDER DAYS IN INDIANA.

\begin{tabular}{|c|c|c|c|}
\hline 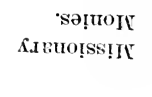 & 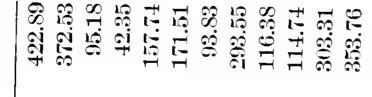 & 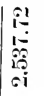 & \\
\hline 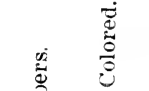 & 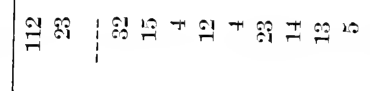 & 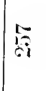 & i \\
\hline 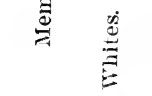 & 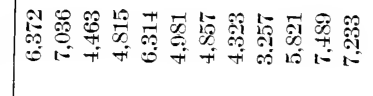 & 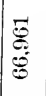 & \\
\hline 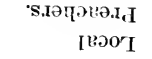 & 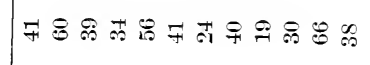 & $\underset{\infty}{\infty}$ & \\
\hline 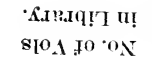 & 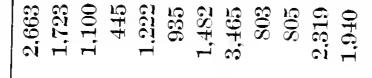 & 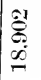 & \\
\hline 'S.IU[Oप’S & 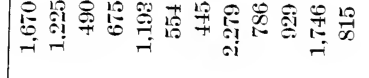 & $\begin{array}{l}5 \\
\mathscr{2} \\
\mathrm{ai} \\
\mathrm{i}\end{array}$ & \\
\hline 's.дәцәвә.L & 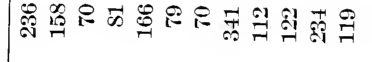 & 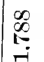 & \\
\hline 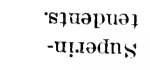 & 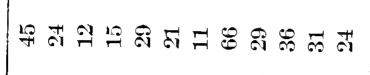 & $\stackrel{9}{9}$ & $\overbrace{\mathscr{d}}^{\infty}$ \\
\hline 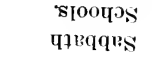 & 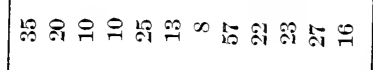 & 象 & 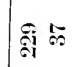 \\
\hline 'səå?uos.n?d & 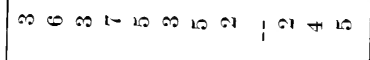 & $\log$ & of \\
\hline sesnoII $\mathrm{K}$ & 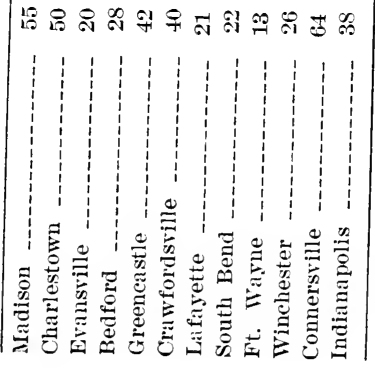 & 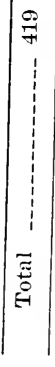 & 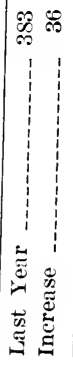 \\
\hline
\end{tabular}


Wednesday Morning, October 25th, 1843.

Conference met, pursuant to adjournment, and was opened with reading, singing and prayer by Brother Ames, and the journals were read and approved.

On motion of Brother Wiley, the Secretary was directed to furnish such papers as he may think fit for publication in the Western Christian Advocate.

Conrad Muth, recommended from the Evansville District, was received on trial.

Brother Eddy, from the committee on Indianapolis church property, made a report, accompanied by the following resolution:

First. Resolved, That the Bishop be respectfully requested to make Meridian street the dividing line between the two charges.

Second. Resolved, That the members who may be cut off by this change shall be permitted to attach themselves to either charge, at their discretion.

Both of which resolutions were indefinitely postponed, and the following were adopted, as amended, as follows:

Third. Resolved, That we advise the Trustees of the two charges to make an equal division of the real estate (exclusive of buildings) which belonged to the Church at the time of division, and that the amount of subscriptions made to the Eastern charge by members of the Western charge shall be deducted from the amount due the Eastern charge, provided such subscriptions be estimated at their cash value.

Fourth. Resolved, That if the parties referred to above cannot agree in the division of the property, that they may be advised to submit the same to arbitration.

Fifth. Resolved, That the preachers in charge of the two stations in Indianapolis and the Presiding Elders of the two districts be instructed to use their influence to carry the above resolutions into effect.

The committee on Church property made report in 
reference to the meeting-house lot in Danville, that they considered the deed to be a good and sufficient one, which report was adopted. The resolutions appended to their former report were taken up and adopted, as follows, viz.: "Resolved, That for the purpose of promoting more uniform action and securing the rights to our property we recommend that hereafter the following order, as far as practicable, be pursued: First, the preacher in charge, or Presiding Elder, secure the consent of a majority of the Society or Societies to which church property is to be conveyed, to their appointment of five trustees; second, that the preacher or Presiding Elder then, within ten days thereafter certify said appointment, together with the consent of the majority having been obtained thereto, to the records of the county.

Resolved, second, by the Indiana Conference, That the members of this Conference be and are hereby instructed in all cases, where bonds for deeds have been given, to procure an execution of a suitable deed, and see that it is duly recorded in the proper offices.

Third. Resolved, That it be and it is hereby made the special duty of all our Presiding Elders at the second Quarterly Meeting in charge for the ensuing year, strictly to enquire into the conditions of Church property, within the bounds of each charge, and to see that the above resolutions be carried into effect.

At the suggestion of Conference, it was voted that Brother J. L. Thompson's book debt be paid out of his appropriattion, and the balance be paid to Brother Beers for him.

On motion of Brother Wiley, "Resolved, That the preachers in the two charges in Indianapolis be a committee respectfully to request the Supreme Judges of this State to say, as gentlemen learned in the law, whether naming the division of this Conference South 
and North Indiana Conference will jeopardize any of our chartered or vested rights."

On motion of Brother S. C. Cooper, "Resolved, That Prof. Larrabee be respectfully requested to furnish a copy of his address on the subject of education for publication in the Western Christian Advocate."

The following preamble and resolutions were presented and adopted: "Whereas, The publishers of books in all parts of the United States have greatly reduced the price of their publications, thereby almost entirely monopolizing the Book trade in many parts of the country and forcing our Books out of the market because of the high price at which they are offered for sale, and as we believe it to be of vital importance to the prosperity of our Church that our Books be placed in the hands of all the people; therefore,

"Resolved, That our delegates to the next General Conference be and they are hereby instructed to use their influence to reduce the price of our Books, that we may be able to compete with other Book sellers, and thereby circulate our books among the people.

"Resolved, That in the opinion of this Conference our object in the selling of Books should be to spread religious knowledge and not to make money."

The committee on the Indianapolis Institute made a report, which was adopted, together with the following resolutions :

1. Resolved, That the Indianapolis Female Institute be taken under the patronage of the Conference. Resolved, second, That a committee of three be appointed by the President of the Conference to attend the annual examinations and report to Conference. Third, That we will recommend the Institution to our friends, and use our best exertions to sustain it, and the President was requested to appoint the committee.

The York resolutions were taken up, and on the first, viz.: "The buying or selling of men, women or 
children, with an intention to enslave them, or the holding of them as slaves in any State, Country or District, when the laws of such State, Territory or District will admit emancipation, and permit the liberated slave to enjoy freedom," was concurred in by the Conference by a vote of 92 yeas, 34 nays.

The second, viz.: "Making local preachers accountable for offenses, where they may be committed," concurred in by a vote of 119 yeas, 5 nays.

The third, viz.: Making our rule on spiritous liquors read as follows: "Drunkenness, buying or selling spiritous liquors, or drinking them, unless in cases of extreme necessity," was concurred in by a vote of 91 yeas, 11 nays.

The fourth, viz.: Altering the restrictive rules so as to change our rules on slavery as to read: "The buying or selling men, women or children with an intention to enslave them," was concurred in, by a vote of 91 yeas, 11 nays.

A petition on the subject of slavery was presented from Westfield, which, by a vote of the Conference, was laid upon the table.

The report from the Visitors of the University was read and adopted.

The parchment of Jeremiah Sherwood was presented to the Conference by Brother E. G. Wood. The chair having decided that a minister could not be admitted to orders without a regular recommendation from the Quarterly Meeting Conference.

The Stewards made a report in reference to the superannuated men, dividing them as follows, viz.: That J. L. Thompson, H. Vredeburgh, William Wilson, Robert Burns, William H. Smith, Widow Armstrong, Widow Williams, Brother Griffith's children and Brother Thompson's child be attached to the North Indiana Conference; and that William Shanks, William Knowles, F. C. Holliday, J. A. Brouse, J. C. Harbin, 
J. A. Decker, G. W. Bowles, Widow Moore, Widow Chord, Brother Robinson's, Brother Ray's and Brother Barnes' children, Brother Bremey be placed in the South Indiana Conference, which was adopted.

The committee to whom was referred the selecting of a Life Director made their report, and Conference selected Brother Allen Wiley, and directed the Secretary to furnish him a certificate thereof.

On motion of Brother Ruter, the following resolutions were passed:

Resolved, That we commend to the people in our respective charges to observe Friday, the 22nd day of December next, as a day of humiliation, fasting and prayer; and that we advise them in each society to commence on the evening of that day a four days' prayer meeting, and that such meetings be protracted when circumstances will justify their continuance.

Resolved, That we will endeavor to observe, and that we will recommend our people within the bounds of this conference to observe, Friday, the 26th day of April next, as a day of fasting and prayer, with special reference to the meeting of our ensuing General Conference, fervently praying the Head of the Church so to direct that body, in all their deliberations, that their minds may be to such conclusions as shall most tend to promote the glory of God and advance the interests of the Redeemer's Kingdom upon earth.

Resolved, That during the ensuing Conference year we will endeavor on the evening of each day in the twilight hour, especially to remember our brethren of this Conference, at the throne of grace, praying each for the others, that all may be preserved from evil, that we may greatly increase in knowledge, in holiness and usefulness, and be made more than ever successful in spreading scriptural holiness over the lands.

On motion, Brothers J. A. Brouse and J. C. Harbin were placed in a superannuated relation. 
On motion of Brother E. G. Wood: Resolved, That each preacher in charge be instructed to take up a collection in the month of March next for the purpose of defraying the expenses of the delegates to the next General Conference, and forward it to the nearest delegate.

On motion, the Secretary was directed to furnish a copy of the resolutions on Indianapolis church property to the preacher of the Western charge.

After some notices, Conference was closed, with the benediction by the Bishop.

Wednesday Afteroonn, October 25th, 1843.

Conference met, pursuant to adjournment, in the Methodist Church, and the journals were read and approved.

On motion: Resolved, That the thanks of this Conference be hereby tendered to those religious denominations who have kindly opened their churches for our occupancy during the session of this Conference.

Resolved, That the thanks of this Conference be hereby tendered to the citizens of Crawfordsville and vicinity, who have kindly opened their hearts and houses for our accommodation during the session of this Conference.

The Bishop announced A. Wiley, W. C. Larrabee and J. C. Smith as visitors to the Female Institute in Indianapolis.

On motion, Brother Bruing was placed in a superannuated relation. The Committee on the New York Book Concern made their report, which was accepted and filed away among the Conference papers.

Conference was then closed with singing and prayer by the Bishop. And the appointments were read.

\footnotetext{
M. SIMPSON, Secretary.

JAMES O. ANDREW.
} 


\section{APPOINTMENTS FOR 1843.}

\section{Brookville District.}

A. Wiley, Presiding Elder.

Brookville-M. Miller, Samuel P. Crawford.

Fairfield-James Hill.

Liberty-Francis A. Conwell, J. C. Reed.

Brownsville-Jacob Burner, W. Anderson.

Connersville-William W. Hibben, O. H. P. Ash.

Laurel-George Havens.

Milroy-Landy Havens, J. Wallis.

Greensburg-Joseph S. Barwick.

\section{Indianapolis District.}

James Havens, Presiding Elder.

Indianapolis-Western Charge, L. W. Berry.

Rushville-William C. Smith.

Burlington-John W. Melander.

Shelbyville-Charles B. Davidson, George H. McLaughlin.

Columbus-Williamson Terrell, S. A. Ballingall.

Franklin-J. V. R. Miller.

Pleasant View Mission-John L. Kelly.

Milford-J. Miller.

\section{Rising Sun District.}

James Jones, Presiding Elder.

Lawrenceburg-Richard S. Robinson.

Manchester-Amos Bussey, Samuel Hicks.

Wilmington-Silas Rawson, John S. Winchester.

Milan-E. Lathrop.

Versailles-Henry S. Dane.

Vevay-Thomas A. Goodwin, W. Malick.

Patriot-Hayden Hays, M. Mahen.

Rising Sun-William M. Daily.

Lawrenceburg German Mission-J. Swahlen. 
Madison District.

A. Eddy, Presiding Elder.

Madison-Wesley Chapel, James Crawford. 'Third Street-John W. Sullivan.

Canaan-William Morrow, Thomas M. Eddy.

Moorfields-Thomas S. Gunn.

Vernon-Francis H. Carey.

Paris-William McGinnis, E. W. Caldwell.

Lexington-Constant B. Jones, James Mitchell.

New Philadelphia_J. Whiteman, Samuel H. Ports.

New Washington-Lewis Hurlbut.

E. R. Ames, Missionary Secretary.

New Albany District.

William V. Daniel, Presiding Elder.

New Albany-Wesley Chapel, Enoch G. Wood. Centenary Church, C. W. Ruter.

Jeffersonville-Hosier J. Durbin.

Utica-Charles Bonner.

Charlestown-John Kiger.

Greenville-Thomas Ray, Thomas H. Sinex.

Salem-Greenbury C. Beeks.

Corydon-Daniel S. Elder.

Elizabeth-Emmons Rutledge, F. A. Hester.

Evansville District.

John Kearns, Presiding Elder.

Evansville-Samuel Reed.

Mt. Vernon-William M. Fraley, J. Julian.

Cynthiana-William Bratton, P. J. Beswick.

Princeton-Ebenezer Patrick, J. H. Clippenger.

Boonville-E. Oldham.

Rockport-Alfred B. Nesbit, J. Corwin.

Petersburg_J. Ingle.

Paoli-P. R. Guthrie, George B. Jocelyn.

Rome-A Wilkerson.

Evansville German Mission-H. Koenecke, C. Muth. 
Bedford District.

John Miller, Presiding Elder.

Bedford-Elijah Whitten.

Brownstown-Seth Smith.

Leesville-Elam Genung.

Bono-Daniel McIntyre.

Orleans-George W. Walker.

Bloomington-Cyrus Nutt.

Springville-LeaIdes Forbes.

Scotland-T. Ryan.

Martinsville-J. B. DeMott.

Mooresville-D. DeMott, J. Crawford.

Brown Mission-Wesley Dorsey.

Vincennes District.

U. S. Talbott, Presiding Elder.

Vincennes-Anthony Robinson.

Carlisle-S. Ravenscroft, C. Mapes.

Lebanon-Ezra L. Kemp.

Prairieton-John Talbott.

Bowling Green-Thomas G. Crawford.

Point Commerce-George W. Ames.

Spencer-Eli C. Jones.

Washington-James R. Williams.

Putnamville-Asa Beck.

Greencastle District.

G. M. Beswick, Presiding Elder,

Greencastle_John Daniel.

Montgomery-George W. Warner.

Russellville-J. B. Birt, E. Lilliston.

Rossville-Jared B. Mershon.

Rockville-Philip May.

Terre Haute-S. T. Gillett.

Newport-J. J. Cooper, M. Johnson.

Little Walnut Mission-J. R. Tansey. 
Indiana Asbury University-M. Simpson, President; W. C. Larrabee, Professor; S. C. Cooper, Agent, for the northeln portion of the Conference; Isaac Owen for the southern portion.

\section{Crawfordsville District.}

J. C. Smith, Presiding Elder.

Crawfordsville-Richard Hargrave.

Crawfordsville Circuit-Thomas J. Brown.

Alamo Mission-Joseph White.

Covington-Amasa Johnson, W. Posey.

Perryville-Samuel Brenton.

Newtown-Thomas Bartlett, J. B. Johnson.

Augusta-Jacob Myers.

Williamsport-B. T. Griffith.

Danville-D. F. Stright, R. H. Calvert.

\section{Lafayette District.}

A. Wood, Presiding Elder.

Lafayette-Jacob M. Stallard.

Dayton-Horatio N. Barnes.

Lebanon-H. Wells, J. H. Newland.

Frankfort-Draper Chipman.

Camden-Franklin Taylor.

Delphi-Cornelius Swank.

Monticello-John Edwards.

Rensselaer Mission-Rosetter C. Rowley.

Independence-Allen D. Beasley.

\section{Logansport District.}

B. Westlake, Presiding Elder.

Logansport-Isaac M. Stagg.

Kokomo Mission-Jacob Colclazer.

Pittsburg-George W. Stafford.

Winnemeck-Orville H. Boyden.

Upper Wabash Mission-A. Merrill. 
Rochester-Allen Skillman, J. P. Jones.

Liberty Mills-Charles W. Miller.

Warsaw-E. Anthony.

Leesburg-Enoch Wood.

Peru-William F. Wheeler, N. Greene.

South Bend District.

C. M. Holliday, Presiding Elder.

South Bend-E. Holstock, S. B. F. Crane.

Terrecoupee-J. W. Parrott.

Laporte-W. L. Huffman.

Union-Orange V. Lemon, Benjamin Winans.

Valparaiso-Warren Griffith.

Crown Point-To be supplied.

Plymouth-L. W. Monson.

Mishawaka-Zechariah Games.

Middlebury-S. Lamb.

Goshen-Ancil Beach.

Fort Wayne District.

George M. Boyd, Presiding Elder.

Fort Wayne-Hawley B. Beers.

St. Joseph Mission-J. C. Medsker.

Decatur-N. S. Worden.

Auburn-J. Sparks.

Steuben-W. J. Forbes.

Lagrange-Levantus Doud, William Stone.

Wolf Lake-E. S. Blue.

Huntingdon-J. Cozad.

Bluffton-George Guild.

Centerville District.

Joseph Tarkington, Presiding Elder.

Winchester-L. M. Reeves, A. Badley.

Richmond-J. H. Hull.

Centreville-J. H. Bruce. 
Hagarstown-J. W. Bradshaw.

Munceytown-Zelotes J. Clifford.

Granville-John Leech.

Hartford-H. H. Badley.

Portland-A. Carey.

Cambridge and Dublin-John L. Smith.

Williamsburg-B. Webster.

\section{Pendleton District.}

Joseph Marsee, Presiding Elder.

Indianapolis-Eastern Charge, John S. Bayless.

Noblesville-James Scott.

Westlake-S. C. Swayze.

Pipe Creek-Miles Huffaker.

Pendleton-J. C. Crouch.

Andersontown-B. H. Bradbury.

Marion-J. C. Robbins.

Newcastle-Luther Taylor.

Knightstown-John L. Donaldson.

Greenfield-F. F. Sheldon.

William H. Goode, transferred to Arkansas Conference. 


\section{BIBLIOGRAPHY.}

\section{Manuscripts.}

Journal of the Western Conference (1800-1811) and Journal of the Ohio Conference (1812-1839), in two fairly well preserved manuscript volumes, in the possession of the Ohio Methodist Historical Society, in the library of Ohio Wesleyan University, Delaware, Ohio.

Journal of the Indiana Conference (1832-1844), a finely preserved manuscript volume, belonging to the North Indiana Conference, now in the library of DePauw University.

Considerable manuscript material, relating to local churches and circuits, has been available for this study, including the Quarterly Conference Records of the Fali Creek Circuit from 1828; the Quarterly Conference Records of the Crawfordsville station from 1835; manuscript material relating to the founding and history of DePauw University, in the office of the treasurer of the university; some of the records of the old Silver Creek Circuit, the first complete circuit in Indiana, found at the Charlestown Methodist Episcopal Church, the earliest record being dated February 23, 1810.

Much other material of this kind is also available, of more or less importance, every church possessing records, many of which, however, are meager and incomplete. An attempt has been made to collect this material, so that it can more easily be used, and a survey of the North Indiana Conference has been organized. This Conference appointed a Conference Historian in the person of Dr. H. N. Herrick, now de- 
ceased, and also county historians were appointed, who were to write up the history of every Methodist Church in the county. Among these county historians who have turned in material are Rev. C. H. Smith, for Hancock county; Mr. F. A. Walker, Esq., for Madison county; I. W. Krider, for Cass county ; Rev. J. E. Ervin, for Delaware county; Captain M. B. Willis, for DeKalb county; Mrs. M. E. Kiblinger, for Noble county; Rev. H. J. Norris, for Randolph county; Mr. R. S. Truitt, for Hamilton county; Dr. J. M. Moulder, for Howard county; Rev. B. G. Shinn, for Blackford county; Rev. J. B. Cook, for Kosciusko county; Mr. W. E. Mowbray, Esq., for Miami county. The other county historians appointed for the remaining counties in the Conference are Rev. W. J. Myers, Adams county; O. E. Mohler, Allen county; Prof. D. W. Thomas, Elkhart county; Charles E. Neal, Esq., Grant county; Dr. J. W. White, Henry county; Dr. W. C. Chaffee, Huntington county; A. T. Place, Jay county; G. C. Morgan, Lagrange county; Rev. G. H. Hill, Marion county ; Mrs. W. E. Butterworth, St. Joseph county; Mrs. Frank Wier, Steuben county; Mr. M. W. Pershing, Tipton county; Mrs. A. F. Ebbinghouse, Wabash county; Rev. O. S. Harrison, Wayne county ; Prof. P. A. Allen, Wells county, and Rev. C. W. Shoemaker, Whitley county.

The Northwest Indiana Conference also passed resolutions looking toward the appointment of county historians by the district superintendents, but this survey, so far, has resulted in the investigation of but one county-Benton county-by Rev. J. E. McCloud.

Dr. Herrick before his death had compiled a complete appointment record for the North Indiana Conference, and had also put in rough form his first chapter for his intended History of the North Indiana Conference. Dr. Herrick's manuscript has been drawn upon in this study, and in some instances has given valuable assistance. 
"The Western Christian Advocate," begun 1834. One of the most important sources for this study. Besides scattered items, a number of important serial articles, bearing on the early history of Indiana Methodism, have been found in the files of this paper, the most important of which are:

"Introduction and Progress of Methodism in Southwestern Indiana," by Rev. Allen Wiley, in the Western Christian Advocate for 1845-1846. A series of thirtyseven articles describing early circuits and ministers from 1804 to 1832 .

"Methodism in Southwestern Indiana," signed Yesop Edaw. Western Christian Advocate, July 27, August 10, September 28, October 26, 1859.

"The Indiana Conference," 1832-1843. A series of twelve articles running in the Western Christian Advocate for 1858 . By W. W. Hibben.

"The Methodist Magazine," begun 1818. The official quarterly magazine of the Methodist Episcopal Church in the United States. Chiefly valuable for biographies of deceased ministers.

"Minutes of Conferences," Vols. I, II, III, 1773-1845. Bound volumes containing statistics of all the Conferences in the United States, among them being statistics for Indiana from the earliest introduction of Methodism within the State. Also contains brief biographies of deceased ministers.

"The General Conference Journals" contains proceedings of the General Conference, the lawmaking body of the Church, which met every four years. (1812-1844.)

"Disciplines" (1812-1844). Contains digest of Methodist law, Church rules, boundaries of conferences, etc. Revised every four years by the action of the General Conference. 


\section{BIOGRAPHICAL AND AUTOBIOGRAPHICAL.}

Beggs, Rev. S. R.- "Pages from the Early History of the West and Northwest," Cincinnati, 1868. Refers especially to the history of Methodism.

Cartwright, Peter-“Autobiography." Edited by W. P. Strickland, Cincinnati and New York, 1856. Peter Cartwright was associated with the earliest introduction of Methodism into Indiana. This is the best known Methodist frontier biography.

Cox, Sanford-"Recollections of an Old Settler," Lafayette, 1860.

Crooks, George R.- "Life of Bishop Simpson," New York, 1890. Bishop Simpson was the first President of Indiana Asbury University (DePauw University).

DePauw University-Semi-Centennial Reminiscences and Historical Addresses, 1837-1887. Includes addresses by Rev. T. A. Goodwin, on "Reminiscences of Early Days of Indiana Asbury University." SemiCentennial Historical Address of Indiana Asbury, Now DePauw University," by Rev. George L. Curtiss. "Historical Sketch of the Transition from Indiana Asbury University to DePauw University," by John Clark Rıdpath. Greencastle, 1887.

Elliott, Rev. Charles-"The Life of Bishop Robert R. Roberts," Cincinnati, 1844.

Goodwin, Rev. T. A.- "Heroic Women of Early Indiana Methodism" (pamphlet). An address delivered at DePauw University, 1889.

Holliday, Rev. F. C.- "Life and Times of Allen Wiley." Edited by Rev. D. W. Clark, Cincinnati, 1853.

Major, Noah J.-Memoirs of "Pioneers of Morgan County." Edited by Logan Esarey, Indianapolis, 1915 (pp. 334-348). 
Smith, Rev. J. C.- “Reminiscences of Early Methodism in Indiana." Indianapolis, 1879.

Smith, Rev. J. L.- “Indiana Methodism." Contains personal recollections and incidents. Valparaiso, 1892.

Smith, W. C.- "Indiana Miscellany."

Tarkington, Joseph-“Autobiography." Edited, with a long introduction, by Rev. T. A. Goodwin. Cincinnati, 1899.

Welker, T. D._-John Kiger, Conflicts and Triumphs of an Itinerant." Cincinnati, 1891.

Wood, Rev. Aaron-“Sketches" (pamphlet). Facts and reminiscences of early days in Indiana, by a prominent itinerant preacher. Indianapolis, 1883.

\section{GENERAL.}

"Camp-Meetings." An essay written to vindicate the camp-meeting. Cincinnati, 1856.

Cummings, A. W.- "Early Schools of Methodism." New York, 1886.

Dow, Rev. Lorenzo-“The Writings Of." Cincinnati, 1853. An eccentric evangelist, who traveled over the country in the early nineteenth century.

Emory, Robert-"History of the Discipline of the Methodist Episcopal Church." New York, 1844.

Esarey, Logan-“A History of Indiana from Its Exploration to 1850." Indianapolis, 1915.

Finley, Rev. J. B.- "Sketches of Western Methodism." Biographical, historical and miscellaneous, illustrative of pioneer life. Edited by W. P. Strickland. Cincinnati, 1857. Contains a biography of Rev. William Burke, who was Secretary of the old Western Conference at the time of the introduction of Methodist preaching in Indiana.

Holliday, Rev. F. C.- "Indiana Methodism" down to 1872. Cincinnati, 1873. The most complete history of Methodism, but poorly organized, with no index. 
Larrabee, W. C.- "Asbury and His Coadjutors," two volumes. Cincinnati, 1853. Contains biographies of Bishop William McKendree and Bishop Robert R. Roberts.

Porter, Rev. James-“A Compendium of Methodism" (sixth edition). Boston, 1853.

"Readings in Indiana History." Edited by a committee of the History Section of the Indiana State Teachers' Association. Bloomington, 1914. Chapter XVI, "Religious Life of the Pioneers."

Sherman, David-"History of the Revisions of the Discipline of the Methodist Episcopal Church." New York, 1874.

Stevens, Abel-"History of American Methodism." Cincinnati, 1868. A general account of the Methodist Episcopal Church in the United States.

Sweet, William W.- "The Methodist Episcopal Church and the Civil War." Cincinnati, 1912. 



\section{INDEX}

Agents, Indiana Asbury Uni., 71. $177,179$.

Alleghany College, 64.

American Bible society, 174, $254,268$.

American Colonization society. 217.

Ames, Edward R., 52, 65, 75. 85 , S8, 203, 214, 2*3, 316.

Andrew. James O., 86, 305, 327 .

Appointments, 28-29, 78, 108$110,120-122,136-138,151-153$, 166-168, 199-203, 218-222, 239243, 269-273, 181-184, 298-303, 330-333.

Arkansas, 32.

A rmstrong, James, 39, 40, 45, $56,57$.

A rrington, Alfred W., 53, 92-93.

Asbury, Bishop Francis, 17, 26. 83.

Ashwortl!, Moses, 8, 9.

Attica, 46.

Axley, James, 16, 20, 21.

Baptists, 2, 6, 10, 12, 13, 47, 60. 8.2. S3.

Bascom, H. B., 65.

Bayless, J. S., 75.

Bealuchamp, William, 36, 3s.

Berlford circuit, 6 \%.

Beggs, stephen R., 44, 45, 46, 4!).

Beswick, G. W., S1.

Biglow, Russell, 39.

Blackman, Learner, 16.

Bloomingtom, 32, 36, 44. 4li, fili. 68, 81 .

Blue River circuit, 24, 36.

Boonville, tz.

Boston, 39.

Boundaries, conference, 215 .

Brookville, 5, 14, 32, 80.

Brouse, J. A., 71.

Prownstown, 80.

Burke. Willinm, 2, 16. 17. 1s.

Jinns, Robert, s1. liusloe, 10, 19.

13y-LiWs, 94-97, 123, 139, 245. 275.

(imll Mleetings, 23, 48, 49, 50).

"Camphellites," 82, 83.

('iriwright, Peter, 5, 10, 16, 19. 20,70

('enteniry of American Methodisn, 77,204 .

('enterville, 57, 66, 69, 80, 122, 27.3.

Character, examination of, 76 .

(ha rlestown, $4,9,32,36,42,45$, 81 ; district, 56 .

('hristian Adrocate and Journal, 87 .

Cincinnati, 46, 48 .

Clark, George Rogers, 1.

Clark's Grant, 1, 4, 5, 8.

Comnersville, 35,36 ; district, 81 .

Constitutional convention, 30 .

Cooper, J. C., 71, 79.

Corydon, 32, 36.

Course of Study, 107, 108, 212. $213,249,290,291$.

Covington, 46.

Cravens, William, 36.

Crawfordsville, $45,46,57,86$, 303 ; district, $74,81$.

Crume, Moses, 6, 15, 18.

Cull, Hugl, 8, 30.

Daily, W. M., 68, 71, 261, 262.

Danville, circuit, $68,73,74$.

Denrborn county, 6 .

I ebates, 81,82 .

Deep River mission, so.

Delaware, 38.

Delphi, $46,73$.

Detroit, 80 .

Division of the Indiana Confelence, S8, 276, 295, 306, 307. $322,323$.

Dress of pleachers, 44, 75, 119. 215. 
Lddy, A., 75, 81, 8s, 214, 222, 316.

Education, 41, 56, 58-66, 101-103, $127,132,133,134,135,14 \mathrm{~S}-$ $150,154,164,324$.

Edwardsville, Ill., 44.

Eel River, 36.

Llizabethtown, 6.

Elliott, Cbarles, 57. \&5, 175.

Elkhart, 6S, 74 .

linon cirenit, 12.

kvansville. 80,82 .

Eall Creek circult, 43, 45.

Falyette county, 15.

Fifth collection, 233.

Findley, James B., 49, 85, 255.

Flatrock, 36.

Hetcher, Calviu, 63, 65.

Fort Wayne, 45, 68, 73. 82 ; mission, 56 .

Irranklin county, 15.

Franklin, 45: college, 60.

General Conference (1816), 83, (1824) 42, 86, 217; delegates (1836) 57, (1840) 75, (1840)

214-215, (1844) 88, 316.

Germans. $81,315$.

Goodwin, T. A., 66, 76, 77.

Greencastle, 45, 63, 73, 81, 85 .

Greenfield, 42.

Greenville circuit, 35 .

Greenville, treaty of, 1.

Greensbnrg. 42.

Griffith. Walter, 12.

Hamilton, Ohio, 6.

Hanover College, 60.

Hargrave, Richard, 68, 88, 316.

Harrison, William Henry, 9.

Harrison county, 30.

Havens, James, $39,52,56,59$, 65. 69, 76, S1, S5, \&6, \&8, 163, 169, $177,316$.

Hibben, W. W., 79.

Holliday, Charles, 16.

Holliday, F. C., 73.

Honey Cresk, 36.

Illinois, 9, 32, 40, 41, 42, 44 .

Illinois conference, 44, 47, 51. 115, 129, 130.

Independence, $73,80$.
Indiala, $3,5,7,9,12,13,15,19$, $30,31,32,3 \mathrm{~s}, 40,41,42,45,51$.

Indiana Asbury University, 52, $58-66,67,71,148-150,154,157$ $158,173,177,178,180-181,188-$ 190, 196, 207, 212, 213, 216. अi;, 237, 239, 242, 259, 266. $292-293,317$; first trustees, 64.

Indiana circuits, 8, 19, 27, 32, 3.3. 35.

Indiana conference, 52-56, 57, 70, 71, 72, 73, 75-76, 80, 83, 85, S6: minutes of first session, 90-110; second session, 110122; third, 122-138; fourth, 138-153; fifth, 153-168; sixth, 168-184; seventh, 184-203; eighth, 203-222; ninth, 222243 ; tenth, $243-273$; eleventh, 273-303; twelfth, 303-333.

Indiani University. 60, 62, 66. Indiana, 34.

Indian Wars, 1, 2.

Indianapolis, $32,36,45,46$, 63, 65, 153, 222 ; district, 56, 81; female institute, 324,327 .

Kalamazoo clrcuit. 74 : mlssion, 56.

Kentucky, 2, 3, 4, 5, 6, 8, 10, 15, $17,19,20,22,31,49,71$.

Kentucky conference, 2 .

Kentucky State Unlversity, 60.

Ladies Repository, 261, 294.

Lafayette, 45, 57, 62, 63, 129, 139.

Lagrange, 74.

Lakin, Benjamin, 4, 5, 8 .

Langdon, Solomon, 16, 19.

Lil I'orte, 80 ; mission, 56.

Lalrabee, WV. C., 66, 67, 305.

I awrenceburg, 6, 7, 12, 13, 14, $24,35,39,46,74,81,203$.

Liw rence county, 83 .

Lebanon, 80 .

Liquor, 69, 147.

Logansport, 46. 73, 81; misslon, 45.

Lonisville, 72.

Maddox, James, 66.

Madison circuit, 35 ; district, 56, 79,81 . 
Madison, Indiana, 15, 44, 45, 46. 63, 104

Marriage of preachers, 53-55. 258.

Martinsville, 82.

Miassachusetts, $3 \mathrm{~s}$.

Ickendree, William, $3,4,16$. $34,42$.

Meeting houses, 25, 26.

Membership, 48, 51, 57, 67, 71. $73,74,75,80,85$.

Miımi River, 3, 5, 7, 15, 19 ; district, 16, 22, 35: Iniversity. 61.

Michigan, 51, 79 : conference, 81 .

Miller, John, S1, s8, 316.

Missouri, 9, 32, 35, 38, 40, 42.

Mitrhell, Andrew, 4.

Monticello, 73.

Mooresville, so.

Morris, Bishop, Thomas, 75, 85. $206,274$.

Mount Carmel, Ill., 44.

Hount Sterling, 36.

Ifount Vernou, 42.

National Road, 43, 48.

New Albany, 32, 46, 52, 71, 72, 74, S2,90, 106, 165, 169 .

New Albany Semlnary, 164-197.

Newcastle, 43.

New Harmony, 40.

New Jersey, 22.

New York, 31, 38.

Newton circuit, 80.

Noblesville circuit, 68 .

Nortl Carolina, 2, 17, 31 .

Northwestern Christian Advocate, so.

Nutt. Cyrus, 64, 66.

()glesby, Joseyh, 6, 7, 144, 162. 163-164.

Oinio, 14, 15, 17, 19, 38.

Ohio Conference. $2,16,24,35$. 39, $41,42$.

Ohio River, 31, 72.

Oxford circuit. 15, 35.

Paine, Sela, 7.

Paoli, 42.

Paris circult, 68.

Parker, Samuel, 4, 9, 16, 22.

Patokil circuit, 13, 16, 24, 36, 41.

Pennington, Dennis, 30.
Pemusylvania, 31.

l'eru, 73.

I'ine C'reek, 45, 74.

Plainfield, so.

Population, 1, 2, 30, 31, 33, 47.

Portland, 46.

Preachers Aid society, 56, 111, 116, 129, 130, 147, 177, 186, 193, 194, 231, 144, 147, 175, $198,304,312$.

I'resbyterians, 2, $10,60,82,83$, 86.

I'residing Elders, 16, 17, 76, 81 .

Putnamville, 63.

Quaker's, 2, 45, 4!).

Railloads, 64.

Lay, John, 71 .

Records, Church, 191, 192.

Lichmond, 5, 25, 45, 49; distrlet, 66.

Rising Sun, 32, 74 .

Roberts. Bishop Robert R., 42. 75. 83-85, 88, 89, 99, 112, 114. $122,138,159,203,214,217$. $235,243,256,279,286,315$, $31 \mathrm{~S}, 319$.

Robertson's, 3, 9, 23 .

Rockport, 80.

Rockville, 45, 63, 73, 177, 184, 199.

Rushville, 42, 74 .

Ruter, Calvin, 39, 41, 52, 65, 75 . S1, S4, S8, 110, 112, 154, 169 . $214,223,316$.

Salary, of preachers, 35; bishops, 83, 84.

Salem, $42,46$.

Sile. John, 6, 16, 17, 18, 19.

Shakers, 10, 11, 19 .

Shanks, William, 56. 59, 71.

sleelbyville, $42,74$.

Silver Creek circuit, 5, 8, 9, 14 . $17,24,25$.

Simpson, Matthew, 52, 65, 67. $77-78,85,88,204,259,274$. 316.

Slavery, 20, 36, 72, 86, 87, 209 . 324, 325.

Smitl, J. C., 71, 8\&, 145, 146. $185,316$.

Soule, Bishop Joshur, 42, 53, 57, $71,72,75,89,90,110,171$, 184, 224. 
South Bend, 45, 81; mission, 56. south Carolina, 5, 31.

Spaiks, Elijah, 12 .

sit. Joseph Mission, 56.

State College, 59, 60.

statistics, Conference, 285, 321.

Stringe, John, 15, 35, 50, 53. 106. 115.

Swiss, 31.

Tallott. Euward, 4.

Talkington, Joseph, 39, 40, 43 , 69) 74.

Temperance, 70, 147, 197, 198, 325.

Tennessee, 2, 5, 7, 31: conference, 2, 16, 25.

Thanksgiving, 175, 293, 326 .

Terre Haute, 83.243.

Theological Seminaries, 62 .

Thompsou, Jannes L., 56, 59.

Tippecanoe. 13.

Tobacco, 69, 71, 320 .

Einion county, 15.

Iniversalists, s2.

Vermillion, 42.

Vevay, 31, 67.

Vincennes, 1, 9, 10, 13, 14, 19, $24,36,42,43,44$; district, 56 , 81 ; University, 60.

Virginia, 2, 15, 17, 31, 36, 71.
Wabash circuit, 24.

Wabash district, 16, 19.

Wabash, upper mission, 56.

Walker, Jesse, 16, 70 .

Ward, James, 16.

War of $1812,14$.

Warsaw mission, 73, so.

Watson's Institutes, 55.

Watson, James V., 79.

Wayne, General Anthony, 1, 2, 5 : circuit, 48,49 ; county, 15 , $30,50$.

Wesleyan university, 67 .

Western Christian Advocate, 57. $60,70,72,77,113,117,131$. $261,294$.

Weakley. J. W., 65.

Western Conference, 2 (note), $4,5,7,9,16$.

Wheeler, John, 66.

White Lick, 45.

White Pigeon, 79, 80.

Whitewater, circuit, $6,7,12,14$, $15,18,23,35,45$; college, 66 .

Wiley, Allen, 8, 19, 35, 39, 43, 52. $56,58,65,74,75,81,84$. $153,214,316$.

Winans, William, 9.

Winchester, 81.

Wood, Aaron, 75, 80, 81, 88, 214, 316.

Wood, E. G., 73, 81. 



